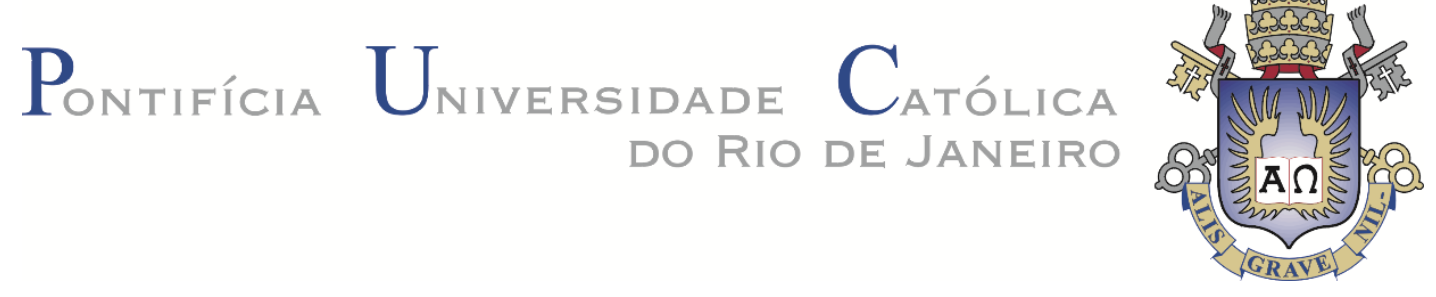

Carolina Manhães Silva

\title{
Avaliação do mecanismo de ruptura de encosta do Santo Antônio Além do Carmo, Salvador, BA
}

Dissertação de Mestrado

Dissertação apresentada ao Programa de Pós-graduação em Engenharia Civil da Pontifícia Universidade Católica do Rio de Janeiro como requisito parcial para obtenção do grau de Mestre em Engenharia Civil.

Orientador: Prof. Tácio Mauro Pereira de Campos

Co-orientador: Prof. Luis Edmundo Prado de Campos

Rio de Janeiro

Julho de 2018 


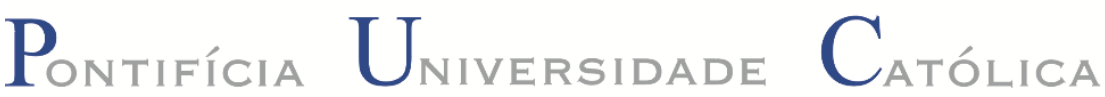 \\ DO RIO DE JANEIRO}

Carolina Manhães Silva

\section{Avaliação do mecanismo de ruptura de encosta do Santo Antônio Além do Carmo, Salvador, BA}

Dissertação apresentada como requisito parcial para obtenção do grau de Mestre pelo Programa de Pós-Graduação em Engenharia Civil da PUCRio. Aprovada pela Comissão Examinadora abaixo assinada.

Prof. Tácio Mauro Pereira de Campos

Orientador

Departamento de Engenharia Civil e Ambiental- PUC-Rio

Prof. Luis Edmundo Prado de Campos

Co-Orientador

Universidade Federal da Bahia

Prof ${ }^{\mathrm{a}}$. Raquel Quadros Velloso

Departamento de Engenharia Civil e Ambiental- PUC-Rio

Prof. Vitor Nascimento Aguiar

Departamento de Engenharia Civil e Ambiental- PUC-Rio

Prof. George de Paula Bernardes

Universidade Estadual Paulista Júlio de Mesquita Filho

Prof. Márcio da Silveira Carvalho

Coordenador Setorial do

Centro Técnico Científico - PUC-Rio

Rio de Janeiro, 27 de julho de 2018 
Todos os direitos reservados. É proibida a reprodução total ou parcial do trabalho sem autorização do autor, do orientador e da universidade.

Carolina Manhães Silva

Graduou-se em Engenharia Civil pela Universidade Federal da Bahia em Salvador, em outubro de 2013. Ingressou no mestrado em Engenharia Civil na área de Geotécnica na PUCRio em março de 2016. Principais áreas de interesse: Estabilidade de taludes, solos não saturados e geotecnia experimental.

Ficha Catalográfica

Silva, Carolina Manhães

Avaliação do mecanismo de ruptura de encosta do Santo Antônio Além do Carmo, Salvador, BA / Carolina Manhães Silva ; orientador: Tácio Mauro Pereira de Campos ; co-orientador: Luis Edmundo Prado de Campos. - 2018.

161 f. : il. color. ; $30 \mathrm{~cm}$

Dissertação (mestrado)-Pontifícia Universidade Católica do Rio de Janeiro, Departamento de Engenharia Civil, 2018.

Inclui bibliografia

1. Engenharia civil - Teses. 2. Solo residual. 3. Sucção. 4. Infiltração. 5. Análise de estabilidade. I. Campos, Tácio Mauro Pereira de. II. Campos, Luis Edmundo Prado de. III. Pontifícia Universidade Católica do Rio de Janeiro. Departamento de Engenharia Civil. IV. Título. 


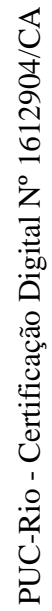

À Deus e minha família 


\section{Agradecimentos}

Ao meu orientador, prof. Tacio M. Pereira de Campos, pela paciência, conhecimento compartilhado e puxões de orelha necessários. Ao meu coorientador, prof. Luis E. P. de Campos, por atender minhas ligações, conversas e por todo o apoio dado para a realização desta pesquisa.

Ao CNPq, pelo auxílio financeiro durante o curso.

Aos funcionários do Laboratório de Geotecnia e Meio Ambiente da PUC-Rio, Edson, Carlos, Amaury e Josué, pelo auxílo nas atividades. Aos funcionários e estagiários do Laboratório de Geotecnia da UFBA (Lui, Romae, Mari, Dilson, Julio, Renato, Ronald e Juliana) pela boa vontade em me ajudar, mesmo na minha ausência. Aos funcionários do Departamento de Engenharia Civil da PUC-Rio, Rita, Fátima, Marcel e Lenilson, pelo atendimento e simpatia durante este tempo.

Ao professor Franklin, pelas conversas, ensinamentos e por sua disponibilidade.

A Juan Sobral, Pedro Avenlino e Carrillo, por compartilharem tão prontamente o material que tinham e tirarem minhas dúvidas. O auxílio de vocês foi fundamental.

Aos amigos da PUC, Bruno, Larissa, Raquel, Ana, Luana, Mari, Andrea, Rodrigo, Alan, Raul, Jainor e Arthur, que ficarão marcados pelo resto da vida. Obrigada pelo apoio sempre presente, ombro amigo, momentos de descontração, discussões acadêmicas e conselhos, vivi momentos inesquecíveis com vocês.

Aos amigos que fiz no Rio, JP, Luana e Vivi, pela companhia e palavras sempre positivas. Vocês me fizeram me sentir mais em casa nesta nova cidade.

Aos amigos de Salvador, que mesmo com a distância estiveram presentes. Vocês estarão sempre no coração.

A minha querida célula, pelas orações. A todos que oraram por mim. 
A Arthur, fiel companheiro de laboratório e amigo, por me ajudar nos ensaios, me ouvir e ajudar a procurar soluções, pelas conversas para levantar meu astral. Que nossa parceria se mantenha além do mestrado.

A Jainor, amigo tão especial, por me ajudar nas análises e torcer sempre por mim. Desejo as melhores coisas para você.

A Ana Carolina, Regina, Mariana, Thiago, Arthur Coelho, Carlos, Camyla, Bernadete, Thaiana, Celso, Lizardo, Karolyn e a todos os colegas que compartilharam material e conhecimentos, além do apoio e companhia no laboratório. Vocês me inspiram a fazer o mesmo por outras pessoas.

Aos professores e amigos Luciene e João Carlos, que me incentivaram a fazer o mestrado, pelas conversas e por estarem sempre dispostos a tirar minhas dúvidas. Vocês são grandes exemplos para mim. Ao professor Paulo Lins, pelo auxílio nas análises numéricas.

A Caesar, meu grande amigo, por estar sempre presente, pelas palavras que me botam para cima, e por não medir esforços para me auxiliar na realização desta pesquisa. A Sidnei, pela amizade e boa vontade que sempre posso contar.

A tia Regilene, Kívia e todos da família, por me receberem e me fazerem sentir em casa. Vocês serão sempre minha família do coração.

A André, companheiro para todas as horas, pela compreensão, ombro sempre presente e por toda a ajuda, desde as pequenas coisas até a ajuda no laboratório.

A Meus pais e irmãos, por todo o apoio, palavras de incentivo, presença e cuidado constates.

A Deus, por tornar tudo isto possível, por colocar estas pessoas no meu caminho e pela presença inegável em minha vida. 


\section{Resumo}

Silva, Carolina Manhães; de Campos, Tácio Mauro Pereira; de Campos, Luis Edmundo Prado. Avaliação do mecanismo de ruptura da encosta do Santo Antônio Além do Carmo, Salvador, BA. Rio de Janeiro, 2018. 161 p. Dissertação de Mestrado. Departamento de Engenharia Civil, Pontifícia Universidade Católica do Rio de Janeiro.

Em países de clima tropical, como o Brasil, é comum a formação de solos residuais, que, por estarem expostos a períodos de seca após as chuvas, costumam encontrar-se não saturados em campo. Portanto, uma análise de estabilidade de um talude considerando o solo saturado não seria a mais condizente com a realidade em um caso destes, devendo ser considerado o acréscimo na resistência ao cisalhamento por conta da sucção na determinação do fator de segurança. Este trabalho teve como objetivo analisar a estabilidade de um talude composto por solo residual de granulito localizado no bairro do Santo Antônio Além do Carmo, Salvador, BA. O programa experimental contou com a coleta de material em campo para realização de ensaios de caracterização química, física e mineralógica, resistência e permeabilidade. A envoltória não saturada, de onde se obteve a relação entre $\phi^{b}$ e sucção mártrica, foi determinada através da função hiperbólica proposta por Vilar (2006). Com os parâmetros obtidos, foram realizadas as análises de infiltração e estabilidade. Os resultados mostraram que o mecanismo de ruptura provável associou-se à elevação do nivel d'água provocado pela infiltração das águas provenientes das fortes chuvas dos dias 8 e 9 de novembro, bem como das águas servidas lançadas no talude pela população. A ação antrópica também se fez presente através de sobrecarga no talude provocada pelo peso das edificações. Conclui-se, então, que seria necessária a ação conjunta da chuva e fatores humanos para que haja uma situação de instabilidade no local estudado.

\section{Palavras-chave}

Solo residual; sucção; infiltração; análise de estabilidade. 


\section{Abstract}

Silva, Carolina Manhães; de Campos, Tácio Mauro Pereira (advisor); de Campos, Luis Edmundo Prado (co-advisor). Evaluation of the failure mechanism of the natural slope of Santo Antônio Além do Carmo, Savador, BA. Rio de Janeiro, 2018. 161p. Dissertação de Mestrado. Departamento de Engenharia Civil, Pontifícia Universidade Católica do Rio de Janeiro.

In countries with a tropical climate, such as Brazil, the formation of residual soils is common, and because they are exposed to periods of drought after rainfall, they are often found unsaturated. Therefore, a stability analysis of a slope considering saturated soil would not be the most consistent in these case, and the increase in shear strength due to suction should be considered on the determination of the the safety factor. The objective of this work was to analyze the stability of a slope composed of residual granulite soil located in the district of Santo Antônio Além do Carmo, Salvador, BA. The experimental program included the collection of material in the field to perform chemical, physical and mineralogical characterization, resistance and permeability tests. The unsaturated envelope from which the relationship between $\phi^{b}$ and matric suction was determined by the hyperbolic function proposed by Vilar (2006). With the obtained parameters, infiltration and stability analyzes were performed. The results showed that the probable failure mechanism was associated to the elevation of the water level caused by the infiltration of the water from the heavy rains of November 8 and 9, as well as the wastewater thrown into the slope by the population. The anthropic action was also present through overloading the slope, caused by the weight of the houses. It can be concluded that it would be necessary the rainfall to work together with the human factors so it will happen an instabilization situation in the study site.

\section{Keywords}

Residual soil; suction; infiltration; stability analysis. 


\section{Sumário}

1 Introdução 22

2 Revisão Bibliográfica 24

2.1 Solos não saturados $\quad 24$

2.1 .1 Origem 24

2.1.2 Fases constituintes $\quad 25$

2.1 .3 Sucção 26

2.1.4 Técnicas de medição da sucção $\quad 27$

2.1.5 Curva característica de retenção de água 30

2.1.6 Resistência ao cisalhamento 32

$\begin{array}{lll}2.2 & \text { Solos residuais } & 36\end{array}$

$\begin{array}{lll}2.3 & \text { Estabilidade de taludes } & 38\end{array}$

2.3.1 Movimentos de massa 39

2.3.2 Estabilidade de taludes de solos residuais 41

2.3.3 Análise de estabilidade 44

3 Área de Estudo $\quad 50$

$\begin{array}{lll}3.1 & \text { Localização }\end{array}$

3.2 Aspectos geológicos, geomorfológicos e hidrológicos 51

3.3 Aspectos climáticos $\quad 54$

3.4 Vegetação $\quad 56$

3.5 Ocupação e Histórico $\quad 57$

$\begin{array}{lll}3.6 & \text { Investigação do subsolo } & 61\end{array}$

3.7 Amostragem 62

4 Equipamentos, técnicas e programa experimental 66

$\begin{array}{lll}\text { 4.1 Caracterização das amostras } & 67\end{array}$

$\begin{array}{lll}4.1 .1 & \text { Caracterização física } & 67\end{array}$

4.1.2 Caracterização química 68

4.1.3 Caracterização mineralógica 68

4.2 Curva característica de retenção de água 69

$\begin{array}{lll}4.3 & \text { Porosimetria de mercúrio } & 70\end{array}$

$\begin{array}{lll}4.4 & \text { Permeabilidade saturada } & 70\end{array}$

4.4.1 Permeâmetro de Guelph $\quad 70$

4.4.2 Permeâmetro de carga constante com parede flexível 71 
$\begin{array}{lll}4.5 & \text { Ensaios de resistência } & 72\end{array}$

5 Ensaios de caracterização 75

$\begin{array}{lll}5.1 & \text { Caracterização física } & 75\end{array}$

5.1.1 Índices físicos $\quad 75$

$\begin{array}{lll}5.1 .2 & \text { Análise granulométrica } & 75\end{array}$

5.1.3 Limites de Consistência $\quad 76$

$\begin{array}{lll}5.1 .4 & \text { Classificação do solo } & 77\end{array}$

$\begin{array}{lll}5.2 & \text { Caracterização química } & 77\end{array}$

5.3 Caracterização mineralógica 78

5.4 Porosimetria de mercúrio 82

5.5 Curva característica de retenção de água 84

6 Ensaios de resistência e permeabilidade 90

$\begin{array}{lll}6.1 & \text { Ensaios de resistência } & 90\end{array}$

6.1.1 Condição submersa 90

6.1.2 Condição seca 97

6.1.3 Envoltórias não saturadas 103

$\begin{array}{lll}6.2 & \text { Ensaios de permeabilidade } & 105\end{array}$

6.2.1 Permeâmetro de Guelph 105

6.2.2 Permeâmetro de carga constante com parede flexível 106

7 Análises Numéricas 107

$\begin{array}{lll}7.1 & \text { Perfil do terreno } & 107\end{array}$

$\begin{array}{lll}7.2 & \text { Análise de infiltração } & 109\end{array}$

7.2.1 Descrição da malha 109

7.2.2 Parâmetros hidráulicos 110

7.2.3 Dados climáticos 112

7.2.4 Condições de contorno e perfil de poropressões inicial 115

7.2.5 Resultados e discussões 116

$\begin{array}{lll}7.3 & \text { Análise de estabilidade } & 119\end{array}$

$\begin{array}{lll}\text { 7.3.1 Parâmetros de resistência } & 120\end{array}$

$\begin{array}{lll}\text { 7.3.2 Resultados e discussões } & 121\end{array}$

8 Conclusões e Sugestões 126

$\begin{array}{lll}8.1 & \text { Conclusões } & 126\end{array}$

8.1.1 Caracterização das amostras coletadas 126

$\begin{array}{lll}\text { 8.1.2 Permeabilidade saturada } & 127\end{array}$

$\begin{array}{lll}\text { 8.1.3 Parâmetros de resistência } & 127\end{array}$

8.1.4 Análises numéricas 127

$\begin{array}{lll}8.2 & \text { Sugestões para futuros trabalhos } & 128\end{array}$ 
9 Referências bibliográficas 130

Anexo I-Perfis de sondagem $\quad 139$

Anexo II - Locação dos furos de sondagem 159

Anexo III - Perfis de SPT, umidade, e densidade real dos grãos 160 


\section{Lista de Figuras}

Figura 2.1- Processos formadores do solo não saturado (Gerscovich, 2016)

Figura 2.2 - Elemento de solo não saturado com fase gasosa contínua (Adaptado de Fredlund e Morgenstern, 1977)

Figura 2.3 - Tipos de fluxo para o método do papel filtro (Adaptado de Marinho e Oliveira, 2005)

Figura 2.4 - Curvas de calibração para os papéis filtro Schleicher \& Schuell no 589 e Whatman 42 (Marinho, 1994).

Figura 2.5 - Potenciômetro WP4C (a) Equipamento (b) Vista interna do equipamento e da câmara (Rocha et al., 2014)

Figura 2.6 - Parâmetros de uma curva de retenção com a quantidade de água representada pelo grau de saturação (Gitirana Jr. et al., 2015)

Figura 2.7 - Alguns formatos típicos de curvas características (Gitirana Jr. et al., 2015).

Figura 2.8 - Envoltórias resistência plana e curva (Caso, 2014)

Figura 2.9 - Perfil de intemperismo para rochas metamórficas e ígneas intrusivas (Deere e Paton, 1971, apud Calle, 2000)

Figura 2.10 - Variação do fator de segurança de uma encosta não saturada com a sucção (Ignacius et al., 1991 apud De Campos, 1997)

Figura 2.11 - Distribuição da taxa preciptada ao longo do tempo

(Gerscovich, 2016)

Figura 2.12 - Evolução de uma frente de saturação com o tempo (Gerscovich, 2016)

Figura 2.13 - Divisão da superfície de ruptura potencial em fatias (adaptado de Abramson et al., 2001)

Figura 2.14 - Forças atuantes em uma fatia (adaptado de Fredlund et al., 2012)

Figura 3.1 - Localização da área de estudo 
Figura 3.2 - localização do Centro Histórico de Salvador (Ribeiro, 2011)

Figura 3.3 - Esquema da falha de Salvador (Projeto Caminhos Geológicos da Bahia, 2004)

Figura 3.4 - Aspecto dos materiais visualizadas no local: (a) camada superficial, provável aterro, (b) e (c) solo residual e (d) rocha fraturada (Geoeng, 2014)

Figura 3.5 - Afloramento de rocha no pé do talude 53

Figura 3.6 - Presença de ravinas no terreno (Correia et al., 2009)

Figura 3.7 - Temperaturas máximas, mínimas e médias anuais em Salvador (Adaptado de Climate-Data) 55

Figura 3.8 - Preciptação diária de novembro de 2011 (INMET)

Figura 3.9 - Preciptação média mensal de Salvador dos últimos 20 anos (INMET)

Figura 3.10 - Preciptação mensal de 2011 (INMET)

Figura 3.11 - Vegetação presente no talude, com caules inclinados devido à alta declividade do terreno (Correia et al., 2006)

Figura 3.12 - Ação humana na encosta: (a) Sistema de esgotamento precário (Martins et al., 2012); (b) vegetação removida para passagem de moradores; (c) escada de sacaria para acesso (Geoeng, 2014) e (d) Deposição de lixo.

Figura 3.13 - Vista dos deslizamentos ocorridos no talude (Campos, 2011)

Figura 3.14 - Vista do maior deslizamento (Campos, 2011) 60

Figura 3.15- Detalhe do maior deslizamento (CODESAL, 2011) 60

Figura 3.16 - Evolução das fissuras em casa do dia 9 para o dia 12/11 (CODESAL, 2011)

Figura 3.17 - Evolução das trincas no solo do dia 12 para o dia 17/11 (CODESAL, 2011)

Figura 3.18 - Localização dos blocos coletados

Figura 3.19 - Coleta de bloco no campo (AM 2)

Figura 3.20 - Poço para coleta de amostras em profundidade (AM 4 e 5)

Figura 3.21 - Bloco na caixa para transporte 
Figura 3.22 - Visual das amostras coletadas

Figura 4.1 - Embrulhos para impedir a perda de umidade nos corpos de prova e pesagem do papel filtro em balança de precisão de quatro casas decimais

Figura 4.2 - Permeâmetro de Guelph utilizado nos ensaios de campo 71

Figura 4.3 - Permeâmetro de parede flexível 72

Figura 4.4 - Equipamento de cisalhamento direto da PUC-Rio 73

Figura 4.5 - Corpo de prova moldado para ensaio de cisalhamento direto

Figura 4.6 - Critério de definição dos pontos de ruptura (De campos e Delgado, 1995, apud Oliveira, 2013) 74

Figura 5.1 - Curvas granulométricas das amostras 76

Figura 5.2 - Difratograma para a AM 1 (método do pó) 79

Figura 5.3 - Difratograma para a AM 2 (método do pó) 79

Figura 5.4 - Difratograma para a AM 3 (método do pó) 79

Figura 5.5 - Difratograma para a AM 4 (método do pó) 80

Figura 5.6 - Difratograma para a AM 5 (método do pó) 80

Figura 5.7 - Difratograma para a AM 5 (método da lâmina orientada) $\quad 80$

Figura 5.8 - Difratograma para a fração areia da AM 5 (método da lâmina orientada)

Figura 5.9 - Difratograma para a fração silte da AM 5 (método da lâmina orientada)

Figura 5.10 - Difratograma para a fração argila da AM 5 (método da lâmina orientada)

Figura 5.11 - Distribuição dos poros para as amostras 1 e $3 \quad 82$

Figura 5.12 - Distribuição dos poros para as amostras 2, 4 e 5

Figura 5.13 - Distribuição acumulada dos diâmetros dos poros 83

Figura 5.14 - Solução gráfica para determinação dos parâmetros de ajuste de Fredlund e Xing (1994) (Soares, 2005) 86

Figura 5.15 - Curva característica da amostra 1

Figura 5.16 - Curva característica da amostra $2 \quad 87$

Figura 5.17 - Curva característica da amostra $3 \quad 87$

Figura 5.18 - Curva característica da amostra $4 \quad 88$

Figura 5.19 - Curva característica da amostra 5 
Figura 6.1 - Curvas para a amostra 1

Figura 6.2 - Curvas para a amostra $2 \quad 92$

Figura 6.3 - Curvas para a amostra $3 \quad 93$

Figura 6.4 - Curvas para a amostra $4 \quad 94$

Figura 6.5 - Curvas para a amostra 5

Figura 6.6 - Envoltórias obtidas pelos ensaios de cisalhamento direto na condição submersa para as amostras 1, 2 e 4

Figura 6.7 - Envoltórias obtidas pelos ensaios de cisalhamento direto na condição submersa para as amostras 3 e 5

Figura 6.8 - Curvas para a amostra 2

Figura 6.9 - Curvas para a amostra $4 \quad 100$

Figura 6.10 - Curvas para a amostra $5 \quad 101$

Figura 6.11 - Envoltória seca para as amostras 2 e 4

Figura 6.12 - Envoltória seca para a amostra 5

Figura 6.13 - Variação de $\phi b$ em função da sucção para as amostras 2 e $4 \quad 104$

Figura 6.14 - Variação de $\phi b$ em função da sucção para a amostra 5105 Figura 7.1 - Locação dos furos de sondagem 107

Figura 7.2 - Seção transversal do local antes e após o deslizamento 108 Figura 7.3 - Perfil 3D do talude estudado 108 Figura 7.4 - Malha aplicada nas análises $\quad 110$ Figura 7.5 - Condutividades hidráulicas não saturadas para as permeabilidades saturadas encontradas em laboratório

Figura 7.6 - Condutividades hidráulicas não saturadas para as permeabilidades saturadas encontradas em campo 112

Figura 7.7 - Dados diários de temperatura média do ar (INMET) 113

Figura 7.8 - Dados diários de umidade relativa (INMET) 113

Figura 7.9 - Dados diários de evapotranspiração potencial (INMET) 114

Figura 7.10 - Dados diários de preciptação (INMET) 114

Figura 7.11 - Dados diários de precipitação somados com a ação antrópica

Figura 7.12 - Condições de contorno sem águas servidas $\quad 116$

Figura 7.13 - Condições de contorno considerando águas servidas 116

Figura 7.14 - Perfil de poropressões para o caso 1 após 254 dias 117 
Figura 7.15 - Perfil de poropressões para o caso 2 após 254 dias

Figura 7.16 - Perfil de poropressões para o caso 3 após 254 dias 118

Figura 7.17 - Perfil de poropressões para o caso 4 após 254 dias 118

Figura 7.18 - Evolução da poropressão com o tempo para os pontos

A e B

Figura 7.19 - Condições iniciais para as análises de estabilidade $\quad 120$

Figura 7.20 - Variação de $\phi b$ com a sução para o solo residual jovem 121

Figura 7.21 - Fator de segurança para a série 1

Figura 7.22 - Fator de segurança para a série 2

Figura 7.23 - Preciptação, poropressão e fator de segurança em função do tempo para os últimos 10 dias de análise

Figura 7.24 - Segundo deslizamento 124

Figura 7.25 - Terceiro deslizamento $\quad 124$

Figura 7.26 - Quarto deslizamento 125

Figura A.1 - Locação dos furos de sondagem (Adaptado de Geoeng, 2014)

Figura A.2 - SPT e teor de umidade x profundidade para o SPT $01 \quad 160$

Figura A.2 - Densidade real dos grãos x profundidade para o SPT 01160

Figura A.4 - SPT e teor de umidade x profundidade para o SPT $02 \quad 161$

Figura A.5 - Densidade real dos grãos x profundidade para o SPT 02161 


\section{Lista de Tabelas}

Tabela 2.1 - Técnicas de medição da sucção em solos (Adaptado de Fredlund e Rahardjo, 1993)

Tabela 2.2 - Tempo de equilíbrio sugerido para medição de sucção total no método do papel filtro (Marinho, 1994)

Tabela 2.3 - Descrição das camadas de um perfil de intemperismo (Adaptado de Deere e Patton, 1971, apud Augusto Filho e Virgili, 1998)

Tabela 2.4 - Agentes e causas de movimentos de massa (Guidicini e Nieble, 1983, apud Santos, 2017)

Tabela 2.5 - Característcas dos tipos de movimento de massa (Augusto Filho, 1992)

Tabela 3.1 - Principais deslizamentos registrados na área de estudo e entornos desde o início da ocupação de Salvador (Dias, 2014; Silva, 2006; Jesus, 2008)

Tabela 3.2 - Dados das amostras coletadas

Tabela 4.1 - Programa experimental

Tabela 5.1 - Índices físicos médios das amostras 75

Tabela 5.2 - Distribuição granulométrica do material estudado (\%) 75

Tabela 5.3 - Limites de consistência e grau de atividade das amostras 77 Tabela 5.4 - Classificação do material coletado de acordo com o SUCS

Tabela 5.5 - Componentes químicos das amostras 78

Tabela 5.6 - Perda por calcinação das amostras $\quad 78$

Tabela 5.7 - Dados obtidos nos ensaios das amostras 1 a $3 \quad 84$

Tabela 5.8 - Dados obtidos nos ensaios das amostras 4 e 5

Tabela 5.9 - Parâmetros de ajuste pelo método de Fredlund e Xing (1994).

Tabela 5.10 - Umidades volumétricas e sucções de entrada de ar e residuais para as amostras 
Tabela 6.1 - Índices físicos dos corpos de prova ensaiados na condição submersa

Tabela 6.2 - Tensões normais de ensaio e dados da ruptura na condição submersa

Tabela 6.3 - Parâmetros de resistência das amostras na condição submersa

Tabela 6.4 - Índices físcos iniciais dos corpos de prova ensaiados na condição seca

Tabela 6.5 - Índices físicos após o adensamento e finais dos corpos de prova ensaiados na condição seca

Tabela 6.6 - Tensões normais de ensaio e dados da ruptura na condição seca

Tabela 6.7 - Parâmetros de resistência das amostras na condição seca

Tabela 6.8 - Equações das envoltórias não saturadas

Tabela 6.9 - Condutividades hidráulicas saturadas obtidas pelo permeâmetro de Guelph, em cm/s (Adaptado de Cajado e Campos, 2017).

Tabela 6.10 - Condutividades hidráulicas saturadas obtidas pelo permeâmetro de parede flexível

Tabela 7.1 - Casos estudados nas análises de infiltração 


\section{Lista de Símbolos}

\begin{tabular}{|c|c|c|}
\hline & $\theta$ & Umidade volumétrica \\
\hline & $\theta_{s}$ & Umidade volumétrica de entrada de ar \\
\hline & $\theta_{r}$ & Umidade volumétrica residual \\
\hline & $\psi$ & Sucção total \\
\hline & $\psi_{m}$ & Sucção mátrica \\
\hline & $\psi_{o}$ & Sucção osmótica \\
\hline & $\psi_{b}$ & Sucção de entrada de ar \\
\hline & $\psi_{o m}$ & Sucção residual \\
\hline & $u_{a}$ & Pressão de ar \\
\hline & $u_{w}$ & Pressão de água \\
\hline త্ & $\chi$ & Parâmetro de tensões efetivas \\
\hline 产 & $w$ & Umidade gravimétrica \\
\hline$\frac{1}{0}$ & $w_{\text {campo }}$ & Umidade gravimétrica de moldagem no campo \\
\hline 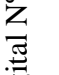 & $w_{p}$ & Umidade do papel filtro \\
\hline م) & $\tau_{r}$ & Resistência ao cisalhamento não saturado na ruptura \\
\hline 焉 & $\sigma^{\prime}$ & Tensão normal efetiva \\
\hline 賕 & $c^{\prime}$ & Coesão efetiva do solo \\
\hline$\frac{1}{2}$ & $\phi^{\prime}$ & Ângulo de atrito interno efetivo \\
\hline & $\phi^{b}$ & $\begin{array}{l}\text { Parâmetro que representa o incremento na resistência ao } \\
\text { cisalhamento devido ao aumento na sucção mátrica }\end{array}$ \\
\hline & $\left(u_{a}-u_{w}\right)$ & Sucção mátrica \\
\hline & $\left(u_{a}-u_{w}\right)_{r}$ & Sucção mátrica na ruptura \\
\hline & $\left(\sigma-u_{a}\right)_{r}$ & Tensão normal líquida no plano de ruptura, na ruptura \\
\hline & $R$ & Constante universal dos gases \\
\hline & $T$ & Temperatura de equilíbrio do solo \\
\hline & $M$ & Massa molecular da água \\
\hline & $p$ & Pressão de vapor do ar \\
\hline & $p_{0}$ & Pressão de vapor do ar de condensação \\
\hline & $a, b$ & $\begin{array}{l}\text { Parâmetros da equação de Vilar (2006), relacionados à } \\
\text { curva característica }\end{array}$ \\
\hline & $F S$ & Fator de segurança \\
\hline
\end{tabular}




\begin{tabular}{|c|c|c|}
\hline & $W$ & Peso da fatia \\
\hline & $N$ & Força normal na base da fatia \\
\hline & $S_{m}$ & Força cisalhante mobilizada na base da fatia \\
\hline & $E_{L}, E_{R}$ & Componente horizontal das forças entre fatias \\
\hline & $X_{L}, X_{R}$ & Componente vertical das forças entre fatias \\
\hline & $A_{L}$ & Força hidrostática \\
\hline \multirow{24}{*}{ 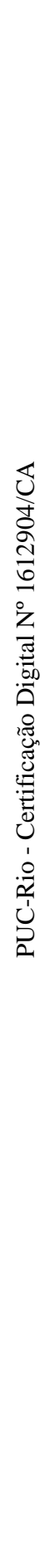 } & $a_{L}$ & $\begin{array}{l}\text { Distância perpendicular da resultante hidrostática para o } \\
\text { centro de rotação }\end{array}$ \\
\hline & $h$ & $\begin{array}{l}\text { Distância vertical entre o centro da base da fatia para a } \\
\text { linha superior }\end{array}$ \\
\hline & $b$ & Largura da fatia \\
\hline & $f$ & $\begin{array}{l}\text { Distância perpendicular entre entre a força normal e o } \\
\text { centro de rotação dos momentos }\end{array}$ \\
\hline & $\beta$ & Comprimento da fatia \\
\hline & $T$ & Força tangencial entre fatias \\
\hline & E & Força normal entre fatias \\
\hline & $\lambda$ & fator escalar obtido pela solução do fator de segurança \\
\hline & $f(x)$ & $\begin{array}{l}\text { Função arbitrária dependente da relação entre as forças } \\
\text { normais e tangenciais }\end{array}$ \\
\hline & $x$ & Abcissa da fatia \\
\hline & $\alpha$ & Inclinação da fatia \\
\hline & $\vartheta_{\text {res }}$ & Inclinação da resultante de Morgenstern e Price (1965) \\
\hline & $W$ & Peso da fatia \\
\hline & $\mathrm{a}, \mathrm{m}, \mathrm{n}$ & Parâmetros de ajuste de Fredlund e Xing (1994) \\
\hline & A & Grau de atividade de Skempton \\
\hline & $\gamma_{\text {nat }}$ & Peso específico natural \\
\hline & $\gamma_{d}$ & Peso específico seco \\
\hline & $G_{s}$ & Peso específico real dos grãos \\
\hline & $e$ & Índice de vazios \\
\hline & $n$ & Porosidade \\
\hline & $S$ & Grau de saturação \\
\hline & LL & Limite de liquidez \\
\hline & LP & Limite de plasticidade \\
\hline & IP & Índice de plasticidade \\
\hline
\end{tabular}


"Vá firme na direção das suas metas, porque o pensamento cria, o desejo atrai e a fé realiza."

Lauro Trevisan 


\section{1 \\ Introdução}

Escorregamentos de taludes, tanto naturais como construídos, são uma importante questão de segurança para a Engenharia Civil, sendo um fator controlador de projetos e até mesmo questão de ordem pública quanto à ocupação do solo urbano (Gerscovich, 2016).

Nas regiões de clima tropical, é comum se ver taludes de solos residuais. Estes têm suas características herdadas da rocha-mãe e dependem do clima, vegetação, topografia, ação antrópica e fatores geológico-geotécnicos, que lhes proporcionam características próprias e uma heterogeneidade. Estão sempre sujeitos a mudanças em suas características, através dos processos físico-químicos que ocorrem continuamente, e geralmente se apresentam não saturados por conta das variações de umidade sofridas em consequência do clima típico destes locais. Estes fatores dificultam o estudo deste tipo de solo, devendo ser realizado um minuncioso programa de investigação para se conhecer suas características.

Por conta destas variações de umidade, é gerada uma pressão negativa de água nos seus poros, chamada de sucção, que contribui na resistência ao cisaIhamento do material através do aumento da coesão aparente. Nos períodos de chuva, a água infiltrada no solo reduz a sucção. Em contrapartida, a evaporação e evapotranspiração das plantas irão provocar um aumento da sucção, com esses processos alternando-se constantemente. A zona não saturada do solo é uma interface dinâmica do talude com o ambiente, e como resultado, seu fator de segurança é afetado dinamicamente pelas mudanças climáticas (Rahardjo et al., 2011).

As análises de estabilidade costumam ser realizadas na pior situação possível, quando o solo está saturado. Porém, o maciço pode vir a romper sem que esteja completamente saturado, estando os movimentos de massa em solos residuais ligados à uma perda de sucção matricial no solo. Assim, faz-se necessário o estudo da estabilidade destes taludes na condição não saturada.

Os mecanismos de ruptura de solos tropicais são associados, muitas vezes, à infiltração de água no solo por consequência de chuvas intensas e/ou prolongadas. Gerscovich (1994) afirma que os fatores que provocam a instabilidade de taludes se dividem em três grupos: variações no estado de tensões totais, redução 
dos parâmetros de resistência e variação das poropressões. Assim, outras possibilidades devem ser também estudadas, afim de se prevenir futuros deslizamentos de acordo com o provável mecanismo dominante no local.

Este trabalho tem como objetivo avaliar o provável mecanismo de ruptura de um talude natural localizado na cidade de Salvador/BA, através de uma retroanálise da ruptura ocorrida em novembro de 2011, após dois dias de fortes chuvas.

Os objetivos específicos são:

1) Realizar a caracterização física, química e mineralógica do material coletado, além de ensaios em campo e laboratório para obtenção dos parâmetros de resistência e permeabilidade;

2) Analisar os resultados dos ensaios;

3) Realizar as análises numéricas de infiltração e estabilidade com os parâmetros obtidos, buscando possíveis mecanismos para a ruptura de 2011.

O trabalho está estruturado em 7 capítulos, organizados da seguinte maneira:

O capítulo 2 apresenta uma revisão bibliográfica dos conceitos de solos não saturados e sua influência na estabilidade de taludes, análise de estabilidade e infiltração em taludes naturais.

No capítulo 3, é apresentada a área de estudo e são descritos os procedimentos de amostragem.

O programa experimental, bem como os equipamentos e técnicas utilizadas estão alocados no capítulo 4.

O capítulo 5 exibe os resultados e análises dos ensaios de caracterização. Os resultados obtidos nos ensaios de resistência e de permeabilidade, além da análise destes, serão abordados no capítulo 6 .

As análises numéricas e seus resultados são apresentados no capítulo 7 .

Finalmente, o capítulo 8 apresenta as conclusões deste estudo e sugestões para futuros trabalhos. 


\section{2 \\ Revisão Bibliográfica}

2.1

\section{Solos não saturados}

\subsection{1}

\section{Origem}

O surgimento dos solos não saturados está fortemente ligado ao clima, estando o solo superficial mais exposto a um processo de dessaturação, desenvolvendo pressões negativas de água, segundo Fredlund e Rahardjo (1993). No ciclo hidrológico, a água das chuvas é direcionada em parte para o solo, parte para a vegetação e parte para os mares, rios e lagos (Gercovich, 2016). Parte do volume dessa água volta para a atmosfera por evaporação e/ou evapotranspiração das plantas e parte se infiltra no solo (Figura 2.1).

Ao ocorrer um período de chuva, seguido por um de seca, como nas regiões de clima tropical, a água presente no solo passa por um processo de evaporação, com a poropressão tendo seu valor reduzido e tornando-se negativa em relação à pressão atmosférica. Assim, o solo não saturado pode ser originado a partir da condição saturada, após a ocorrência dos processos mencionados (Caso, 2014).

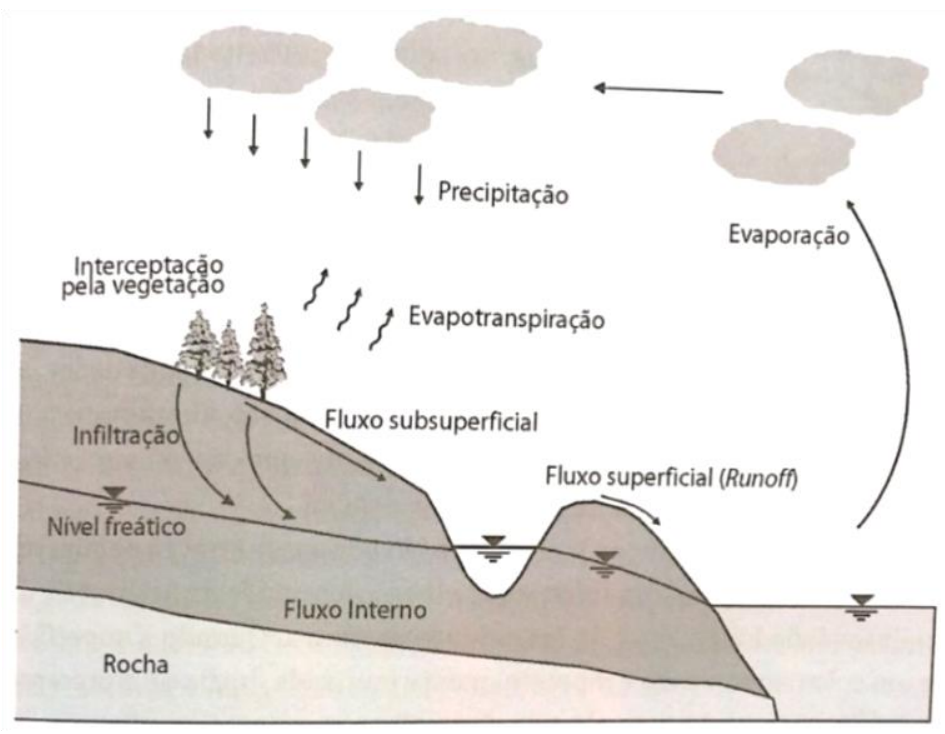

Figura 2.1- Processos formadores do solo não saturado (Gerscovich, 2016) 


\subsection{2}

\section{Fases constituintes}

Na mecânica dos solos clássica, cujos estudos ocorrem na condição saturada, o solo é entendido como um sistema bifásico, composto por água e partículas sólidas. Já o solo não saturado é considerado como trifásico (Figura 2.2), constituído por, além das fases sólida líquida, a fase gasosa. A fase sólida consta nos grãos de solo, a gasosa é formada por ar livre e vapor d'água, e a líquida pela água livre e adsorvida, podendo haver ar e/ou sais minerais dissolvidos.

Fredlund e Morgenstern (1977) propuseram ainda a existência de uma quarta fase na interface ar-água, chamada "mebrana contráctil”, já que esta apresenta propriedades diferentes das outras, como um material independente.

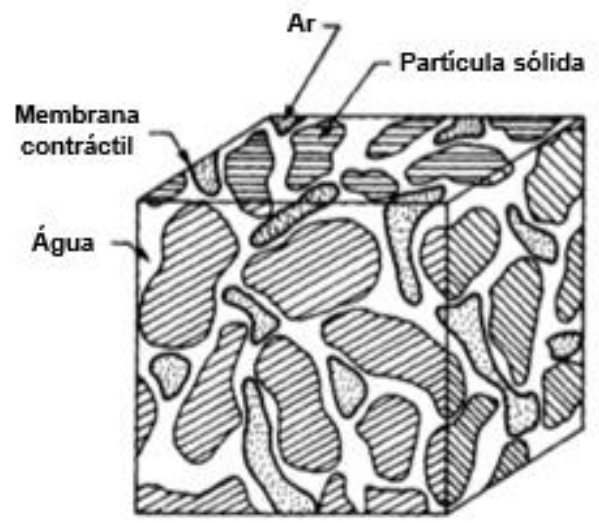

Figura 2.2 - Elemento de solo não saturado com fase gasosa contínua (Adaptado de Fredlund e Morgenstern, 1977)

Como as forças de atração na fase líquida atraem mais intensamente as moléculas de água na superfície do que a fase gasosa, para que ocorra o equilíbrio do sistema, a superfície do líquido se contrai e fica tracionada, o que dá origem à membrana, que se comporta como um material elástico. Esta tração deve-se a uma propriedade chamada tensão superficial, que se associa ao fenômeno da capilaridade. A tensão superficial aproxima as partículas sólidas, aumentando as forças entre estas, surgindo assim a coesão aparente (Motta, 2016), que desaparece com a saturação do solo.

Como o peso e volume da membrana contráctil são desprezíveis, considerase esta como parte da fase líquida sem o aparecimento de erros consideráveis (Fredlund e Rahardjo, 1993). O solo pode ser considerado como um sistema trifásico então, com a fase gasosa contínua (ou seja, sem bolhas de ar ou água intersticial oclusas); caso contrário, considera-se um sistema bifásico. 


\subsection{3}

Sucção

O comportamento mecânico dos solos não saturados está estreitamente ligado à sucção, sendo esta uma componente da sua resistência ao cisalhamento. Diversos estudos foram desenvolvidos desde o século XIX, primeiramente na área da agricultura, tendo sido direcionados para a engenharia geotécnica a partir das décadas de 50 e 60, a exemplo de Fredlund (1987), De Campos (1974), Marinho (1977), Fredlund e Morgenstern (1977), Lu e Likos (2004).

Quando ocorre fluxo de água livre em um solo não saturado, esta poderá ser retida ou adsorvida por ele, sendo necessária a aplicação de uma força externa para desprendê-la. Tal energia aplicada por unidade de volume é denominada de sucção (Lee e Way, 1995, apud Lopes, 2006).

As componentes da sucção podem ser divididas em duas principais parcelas, sendo a sucção matricial $\left(\Psi_{m}\right)$ a resultante de forças de adsorção e capilaridade e a osmótica $\left(\Psi_{o}\right)$ correspondente à pressão osmótica da água no solo:

$\Psi_{t}=\Psi_{m}+\Psi_{o}$

A sucção matricial (ou mátrica) é representada pela diferença entre as pressões de ar e água no solo $\left(u_{a}-u_{w}\right)$, também conhecida como proropressão negativa e equivale à total quando o líquido presente no solo é idêntico à água padrão (destilada), restando somente o efeito da matriz do solo. Já a sucção osmótica refere-se ao potencial osmótico (ou de soluto), associada à diferença de concentração de solutos no solo.

Tratando-se do comportamento do solo não saturado, Edil et al. (1981) verificaram, através de ensaios triaxiais com sucção controlada, que apenas a sucção mátrica o influencia, sendo esta parcela suficiente para seu estudo. Blight (1983) considerou que a sucção osmótica não contribui significativamente na resistência ao cisalhamento. Assim, com base nestas afirmações e no fato dos solos tropicais brasileiros apresentarem pouca ou nenhuma salinidade (Campos, 1984), este trabalho levará apenas em consideração a sucção mátrica para a obtenção dos parâmetros de resistência ao cisalhamento do material estudado, sendo desprezada a sucção osmótica. 


\subsection{4}

\section{Técnicas de medição da sucção}

A medição da sucção no solo pode ser realizada por vários métodos, que são divididos em diretos e indiretos. O primeiro grupo mede a energia de água nos poros, a exemplo do tensiômetro. Os métodos indiretos são baseados na correlação de um parâmetro como umidade relativa, resistividade e condutividade com a sucção do solo através de uma calibração, sendo o principal exemplo o método do papel filtro.

A Tabela 2.1 apresenta as técnicas mais utilizadas na geotecnia. Serão detalhados neste trabalho os métodos do papel filtro e potenciômetro de ponto de orvalho, que foram as utilizadas para a obtenção das curvas características de sucção do material estudado. 1993)

Tabela 2.1 - Técnicas de medição da sucção em solos (Adaptado de Fredlund e Rahardjo,

\begin{tabular}{c|c|c|c}
\hline Técnica & $\begin{array}{c}\text { Medida de } \\
\text { sucção }\end{array}$ & Intervalo (kPa) & $\begin{array}{c}\text { Tempo de } \\
\text { equilíbrio }\end{array}$ \\
\hline Psicrômetro & Total & 100 a 71000 & Minutos \\
\hline Papel filtro (com contato) & Mátrica & 30 a 30000 & 7 dias \\
\hline Papel filtro (sem contato) & Total & 400 a 30000 & Ver Tabela 2.2 \\
\hline Bloco poroso & Mátrica & 30 a 30000 & Semanas \\
\hline $\begin{array}{c}\text { Sensor de condutividade } \\
\text { térmica }\end{array}$ & Mátrica & 0 a 300 & Semanas \\
\hline Placa de sucção & Mátrica & 0 a 90 & Horas \\
\hline Placa de pressão & Mátrica & 0 a 1500 & Horas \\
\hline Tensiômetro padrão & Mátrica & 0 a 100 & Minutos \\
\hline Tensiômetro osmótico & Mátrica & 0 a 1500 & horas \\
\hline $\begin{array}{c}\text { Tensiômetro tipo Imperial } \\
\text { College }\end{array}$ & Mátrica & 0 a 1800 & Minutos \\
\hline $\begin{array}{c}\text { Potenciômetro de ponto de } \\
\text { orvalho }\end{array}$ & Total & 0 a 300000 & Minutos \\
\hline
\end{tabular}

Tabela 2.2 - Tempo de equilíbrio sugerido para medição de sucção total no método do papel filtro (Marinho, 1994)

\begin{tabular}{|c|c|}
\hline $\begin{array}{l}\text { Nível de sucção } \\
\text { total }(\mathrm{kPa})\end{array}$ & Tempo de equilíbrio sugerido \\
\hline $0-100$ & $\begin{array}{c}\text { Não designado, mas certamente }>30 \\
\text { dias }\end{array}$ \\
\hline $100-250$ & 30 dias \\
\hline $250-1000$ & 15 dias \\
\hline $1000-30000$ & 7 dias \\
\hline
\end{tabular}




\subsubsection{1}

\section{Método do papel filtro}

Este método tem como princípio a utilização do fenômeno da absorção para a medida da sucção. Trata-se de uma técnica simples, de baixo custo e rápida. Ao colocar o solo em contato direto ou indireto com um material poroso que tenha a capacidade de absorver água (papel filtro), ocorrerá um fluxo do solo para o material, e estes irão entrar em equilíbrio de pressão, porém com diferentes valores de umidade.

Para que o equilíbrio seja alcançado, é importante que os materiais sejam deixados em contato pelo tempo adequado, devendo ser obedecidas as especificações das Tabelas 2.1 e 2.2 .

A passagem de água do solo para o papel pode acontecer de forma direta, quando o papel é colocado em contato com o solo, ocorrendo o fluxo de fluido (capilar), que permite a medida da sucção mátrica; ou de forma indireta, quando o papel não fica em contato diretamente com o solo e o fluxo que ocorre é de vapor de água, permitindo a medida da sucção total.

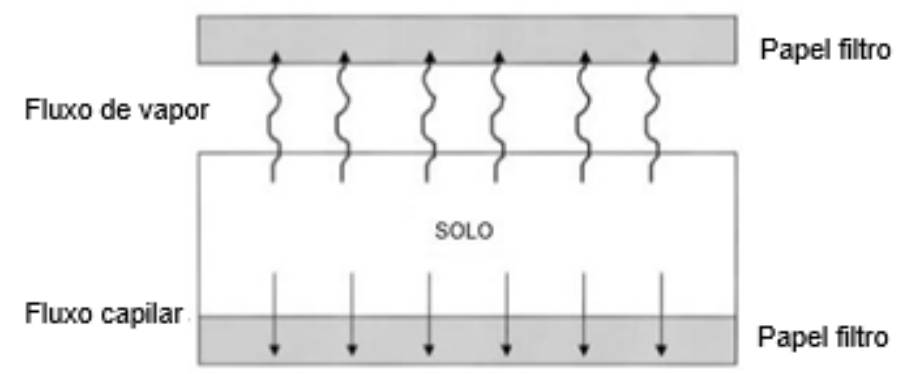
2005)

Figura 2.3 - Tipos de fluxo para o método do papel filtro (Adaptado de Marinho e Oliveira,

Os tipos de papel filtro mais usados são o Schleicher \& Schuell $n^{\circ} 589$ e o Whatman $n^{\circ} 42$, cujas calibrações foram feitas por vários pesquisadores e são aplicáveis tanto para a determinação da sucção matricial como da total. A Figura 2.4 ilustra as curvas mais conhecidas na literatura. Neste trabalho, foi aplicada a equação proposta por Chandler et al. (1992), para o papel filtro Whatman no 42:

$$
\begin{aligned}
& \text { Para } w_{p} \leq 47 \%: \\
& \Psi=10^{\left(4,84-0,0622 \log w_{p}\right)}
\end{aligned}
$$




$$
\begin{aligned}
& \text { Para } w_{p}>47 \%: \\
& \Psi=10^{\left(\left(6,05-2,48 \log w_{p}\right)\right.}
\end{aligned}
$$

Sendo $w_{p}$ a umidade do papel filtro.

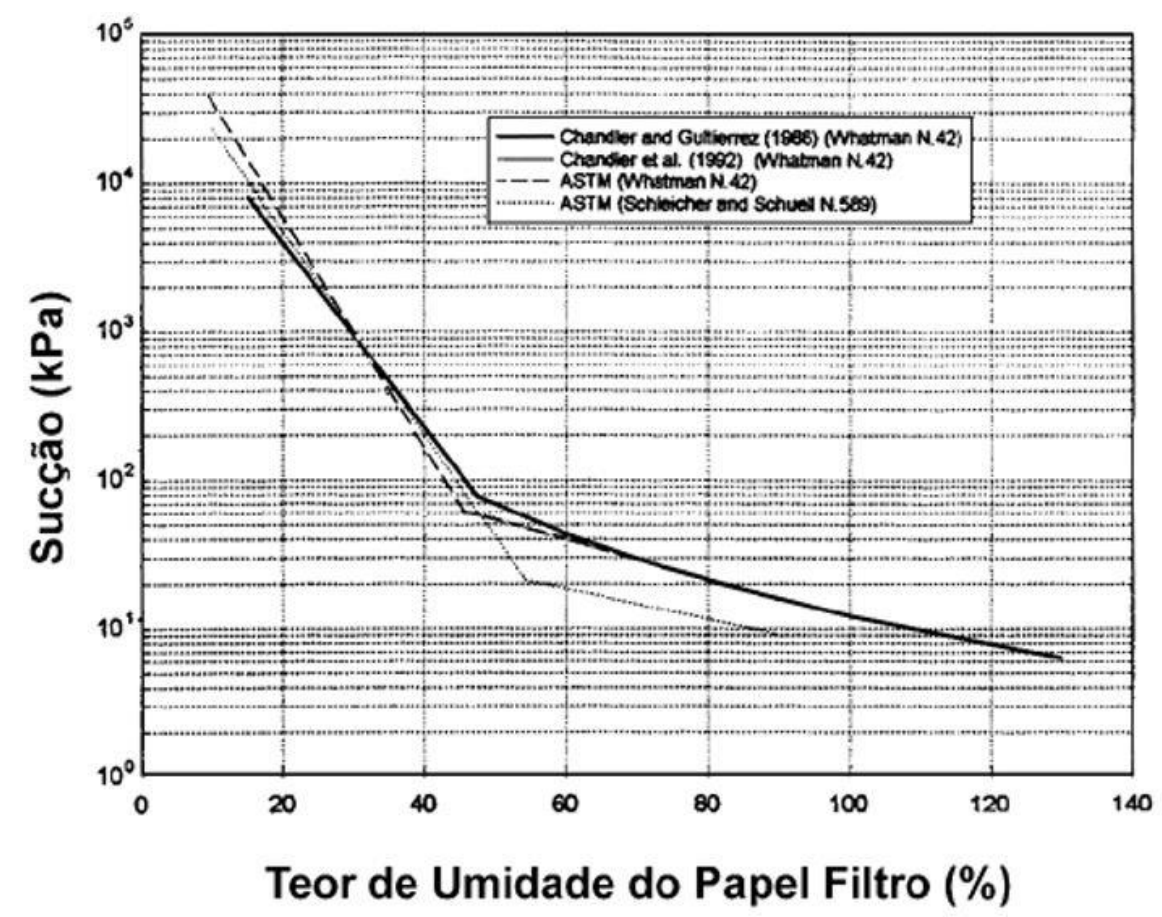

Figura 2.4 - Curvas de calibração para os papéis filtro Schleicher \& Schuell nํ589 e Whatman 42 (Marinho, 1994).

Para garantir a eficácia do método, devem ser considerados, além do tipo de papel filtro, conhecimento da sucção que se quer medir (matricial ou total), calibração e tempo de equalização, a precisão $(0,0001 \mathrm{~g})$ e calibração da balança e a variação de temperatura. Tais aspectos devem ser observados por conta da alta sensibilidade do papel filtro, logo as amostras devem ser armazenadas isoladas termicamente, em ambiente com mínima variação de temperatura.

\subsubsection{2}

\section{Potenciômetro de ponto de orvalho (WP4C)}

Capaz de determinar a sucção de um material de forma rápida e prática, o equipamento usa o ponto de orvalho, ou seja, a temperatura na qual o vapor de água presente no ar passa para o estado líquido através da condensação por gotas (ocorrendo o equilíbrio entre a sucção do solo e a pressão de vapor do ar), para medir a sucção total das amostras. 
Coloca-se a amostra em uma cápsula, que é inserida no aparelho da Figura 2.5 e depois selada, ligando-o então, para verificação da temperatura antes da medição da sucção, que só será realizada se a temperatura da amostra, medida por um sensor infravermelho termoelétrico, for a mesma do ar existente dentro do aparelho, medida por um ponto de orvalho (Motta, 2016; Rocha et al., 2014).

Os resultados obtidos através deste aparelho são melhores para níveis de sucção médios a altos, sendo as leituras de 0 a $100 \mathrm{KPa}$ consideradas de baixa precisão.

O cálculo da sucção é realizado através da equação 2.4, quando o potencial de energia de água na amostra se iguala ao do ar no aparelho.

$$
\Psi=\frac{R T}{M} \ln \frac{p}{p_{0}}
$$

Onde:

$\Psi$ - sucção;

$R$ - constante universal dos gases $(8,31 \mathrm{~J} / \mathrm{mol} . \mathrm{K})$;

$T$ - temperatura de equilíbrio do solo, em Kelvin;

$M$ - massa molecular da água;

$p$ - pressão de vapor do ar;

$p_{0}$ - pressão de vapor do ar de condensação (ou saturação).
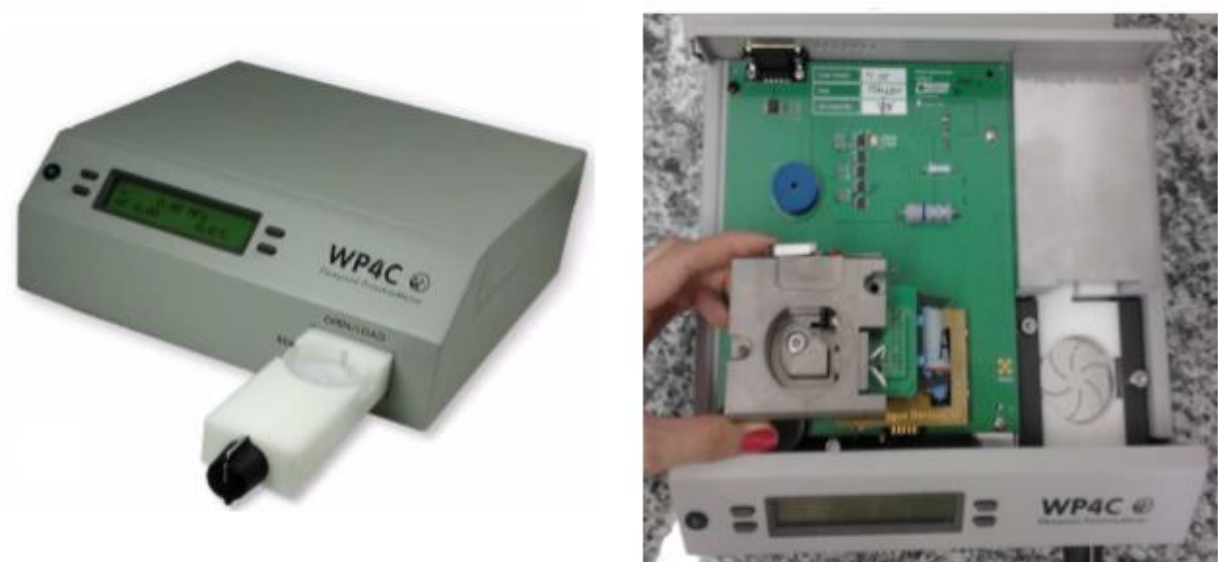

Figura 2.5 - Potenciômetro WP4C (a) Equipamento (b) Vista interna do equipamento e da câmara (Rocha et al., 2014)

\subsection{5}

\section{Curva característica de retenção de água}

A curva característica tem um papel importante na determinação das propriedades de um solo não saturado. Segundo Gitirana Jr et al. (2015), esta expressa 
a relação entre a água que se encontra no material poroso e a energia necessária para removê-la, ou seja, representa a forma como o solo administra a presença de água no seu interior. O teor de água pode ser referido como umidade gravimétrica $(w)$, umidade volumétrica $(\theta)$ ou grau de saturação $(S)$, sendo o segundo o mais utilizado.

Destacam-se dois pontos na curva: a pressão de entrada de ar, que representa o valor de sucção no qual a água começa a ser drenada nos maiores poros $\left(\psi_{b}\right)$ e a umidade residual $\left(\theta_{r}\right)$, na qual inicia-se o estágio residual de dessaturação do solo, sendo necessário fluxo em forma de vapor para a remoção da água dos poros (Lopes, 2006).

Estes pontos dividem a curva em três partes (Figura 2.6), de acordo com Vanapalli et al. (1999). A zona saturada representa o trecho onde todos os poros estão preenchidos por água e onde localiza-se o teor de umidade referente à saturação de $100 \%\left(\theta_{s}\right)$. Na fase de transição (ou zona de dessaturação), a água livre é drenada com o aumento da sucção. Na residual, os acréscimos de sucção provocam variações mínimas na quantidade de água presente no solo.

O valor de entrada de ar é determinado através da interseção da reta horizontal que passa pela umidade de saturação com a reta que passa pelo ponto de inflexão. A umidade residual é obtida da mesma forma, intersectando a reta anterior inclinada com a que aproxima a curva para altos valores de sucção (Caso, 2014).

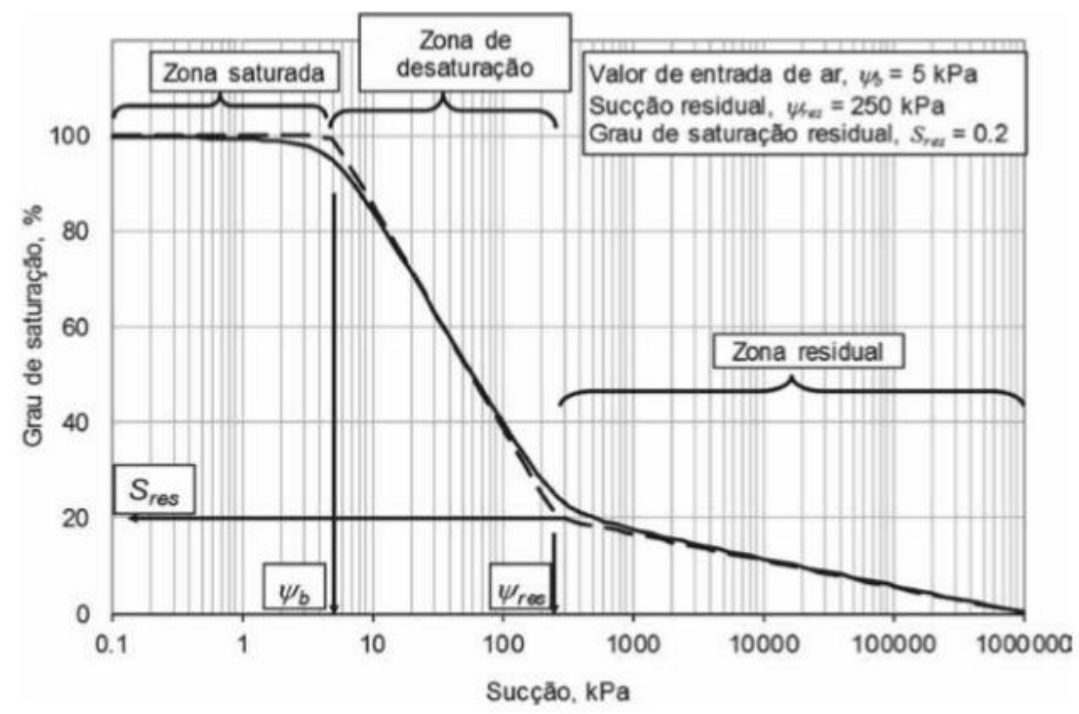

Figura 2.6 - Parâmetros de uma curva de retenção com a quantidade de água representada pelo grau de saturação (Gitirana Jr. et al., 2015)

Pode-se obter a curva para procedimentos de umedecimento e secagem em um mesmo solo, o que gera duas curvas diferentes, cujo afastamento entre elas é chamado de histerese. Isto é provocado pela geometria dos poros, influência do 
ângulo de molhamento nos dois procedimentos e aprisionamento de ar nos poros do solo.

A curva apresentará diferentes formas a depender do tipo de solo (Figura 2.7). Os solos argilosos, que apresentam poros mais uniformes, vão ter uma relação gradual entre teor de umidade e sucção. Já os solos arenosos, que possuem poros maiores por conta dos seus grãos maiores, o que facilita o fluxo de água, apresentam uma queda mais acentuada do teor de umidade com a sucção.

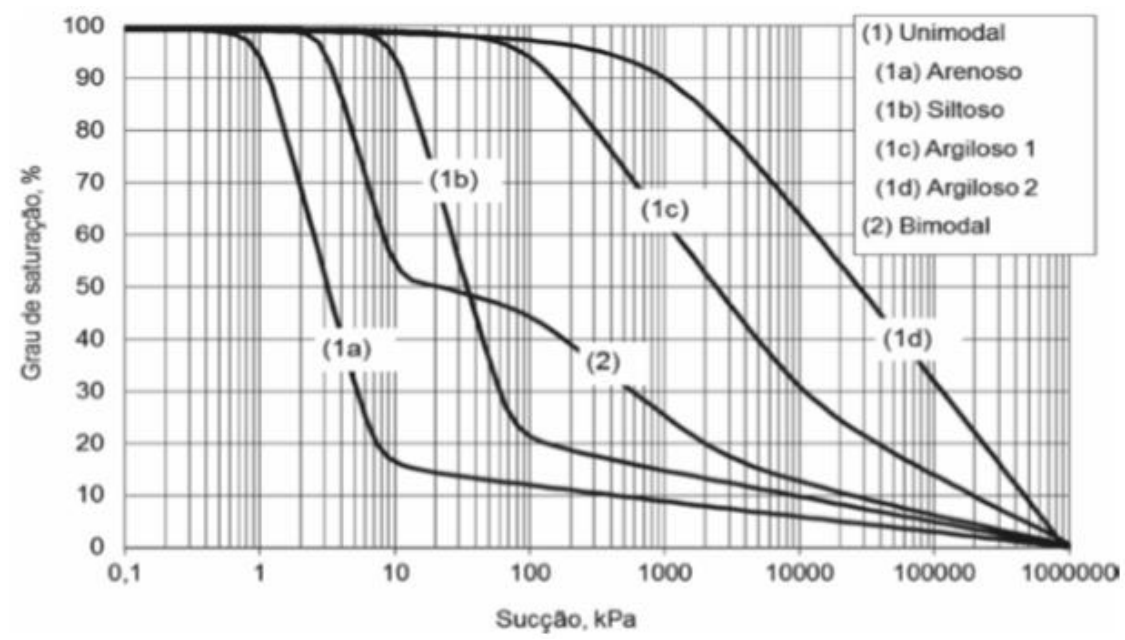

Figura 2.7 - Alguns formatos típicos de curvas características (Gitirana Jr. et al., 2015).

Alguns solos, em especial os solos residuais e coluvionares presentes em regiões tropicais, não apresentam o formato usual da curva de retenção. Estes materiais, devido principalmente ao seu processo de formação, à estrutura de poros e à distribuição granulométrica descontínua, apresentam um comportamento denominado bimodal (Motta, 2016). Estes materiais apresentam dois valores de pressão de entrada de ar e umidade residual, de acordo com seus macroporos e microporos.

\subsection{6}

\section{Resistência ao cisalhamento}

A saturação do solo simula a condição mais desfavorável, e permite conhecer só um aspecto do seu comportamento: a resistência mínima. No entanto, em decorrência da ampla faixa de sucção que pode ser encontrada na natureza, fazse necessário o estudo da variação da resistência associada à variação de umidade, obtendo-se um conhecimento mais aprofundado do seu comportamento (Delgado, 1993). 
Para os solos não saturados, que são formados por um sistema trifásico, não há apenas a ação da água, devendo ser considerada também a presença de ar no solo. Bishop (1959) apresentou a primeira relação para determinação da resistência ao cisalhamento de solos não saturados, baseado no princípio das tensões efetivas e critério de Mohr-Coulomb, de acordo com a equação 2.5:

$$
\tau_{r}=c^{\prime}+\left(\sigma-u_{a}\right)_{r} \operatorname{tg} \phi^{\prime}+\chi\left(u_{a}-u_{w}\right)_{r} \operatorname{tg} \phi^{\prime}
$$

Onde:

$\tau_{r}$ - resistência ao cisalhamento não saturado na ruptura;

$c^{\prime}$ e $\phi^{\prime}$ - parâmetros de resistência do solo saturado;

$\left(\sigma-u_{a}\right)_{r}$ - tensão normal líquida que atua no plano de ruptura, na ruptura;

$\chi$ - parâmetro dependente do grau de saturação do solo;

$\left(u_{a}-u_{w}\right)_{r}$ - sucção mátrica na ruptura;

$u_{a}$ - pressão de ar nos poros;

$u_{w}$ - poropressão.

O parâmetro $\chi$ pode variar de 0 a 1, da condição saturada à seca, respectivamente. Porém, devido às dificuldades encontradas para se obter seu valor, Fredlund et al. (1978) propuseram a equação 2.6, embasando-se no conceito de variáveis de tensão:

$$
\tau_{r}=c^{\prime}+\left(\sigma-u_{a}\right)_{r} \operatorname{tg} \phi^{\prime}+\left(u_{a}-u_{w}\right)_{r} \operatorname{tg} \phi^{b}
$$

Sendo $\phi^{b}$ o parâmetro que representa o incremento na resistência ao cisaIhamento provocado pelo aumento da sucção mátrica.

De Campos (1997) concluiu que, apesar das equações 2.5 e 2.6 apresentarem conceituações teóricas diferentes, estas são equivalentes, tendo-se a seguinte correlação:

$$
\chi \operatorname{tg} \phi^{\prime}=\operatorname{tg} \phi^{b}
$$

A envoltória proposta por Fredlund et al. (1978), também conhecida como envoltória extendida de Mohr-Coulomb, possui representação planar, com os ângulos $\phi^{\prime}$ e $\phi^{b}$ constantes. Na ordenada, plota-se a resistência ao cisalhamento, e nas abcissas as variáveis de tensão, que são a sucção matricial e a tensão normal líquida. 
Diversos autores verificaram experimentalmente a teoria da envoltória tridimensional em diferentes materiais, concluindo que o valor de $\phi^{b}$ varia com a sucção. De Campos (1997) sugere que as variações de $\phi^{b}$ e $\phi^{\prime}$ devem ser analisadas para cada caso individualmente e que a envoltória de resistência de um solo não saturado pode ser representada por uma curva. Segundo Fredlund et al. (2012), a partir do ponto correspondente à entrada de ar, a curva resistência ao cisalhamento x sucção matricial começa a exibir comportamento não linear, com $\phi^{b}$ reduzindo de valor até ficar constante na condição residual.

Quando o solo está saturado, com sucção nula, a influência da tensão normal e poropressão na resistência ao cisalhamento são caracterizados por $\phi^{\prime}$, logo um acréscimo na sucção tem o mesmo efeito nas duas. Atingida a sucção correspondente à entrada de ar, um acréscimo na sucção matricial não provoca um aumento na resistência ao cisalhamento tão considerável quanto um aumento na tensão normal líquida, havendo uma redução no valor de $\phi^{b}$, que atinge um valor constante, praticamente nulo, a partir do valor de sucção correspondente à umidade residual.

(a) Envoltória de Ruptura

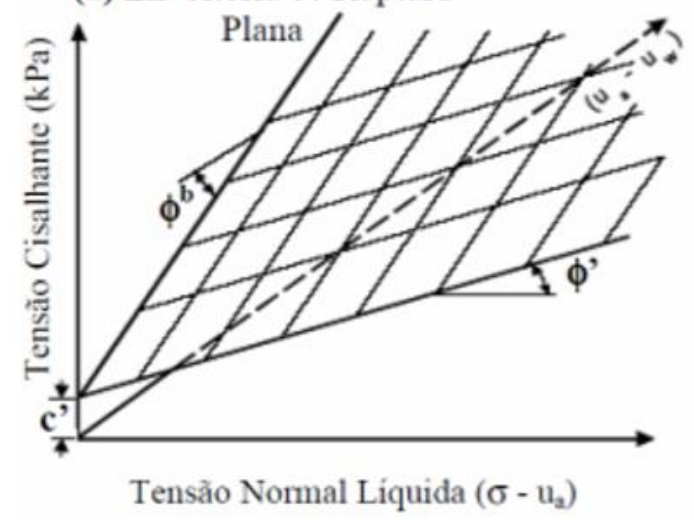

(b) Envoltória de Ruptura

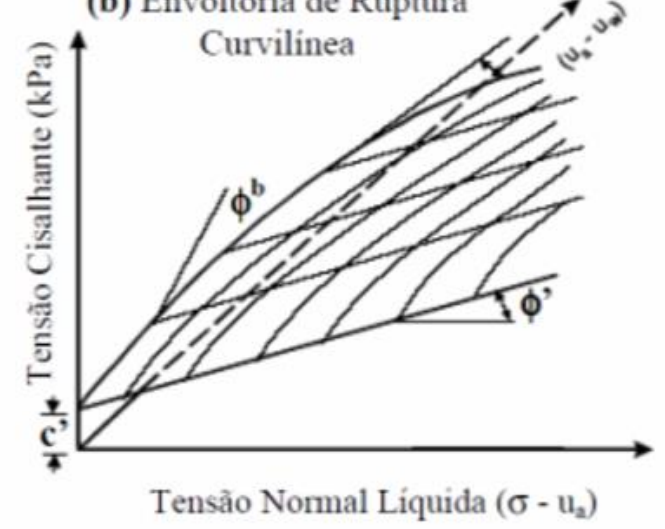

Figura 2.8 - Envoltórias resistência plana e curva (Caso, 2014)

\subsubsection{1}

\section{Estimativa de Vilar (2006)}

As equações anteriormente citadas determinam a resistência ao cisalhamento através de parâmetros não saturados, obtido a partir de ensaios de laboratório. Há, porém, grande dificuldade na obtenção desses dados, seja por falta do equipamento adequado para aplicar e manter a sucção constante, de pessoal especializado ou de tempo hábil para a realização dos ensaios, que são demorados. 
Diantes destas dificuldades, alguns autores como Oberg e Salfors (1997), Lytton (1996), Vanapalli et al (1996), Khalili e Khabbaz (1998), entre outros, propuseram equações para avaliar indiretamente a resistência ao cisalhamento de solos não saturados. Vilar (2006) apresentou um procedimento simplificado, testado para os solos tropicais brasileiros, no qual são utilizados os parâmetros saturados e na umidade residual, quando se admite que a contribuição da sucção na resistência ao cisalhamento chega ao seu valor máximo. Este método considera que a resistência ao cisalhamento aumenta juntamente com a sucção, através de um incremento na coesão do material.

Baseado na equação de Fredlund et al. (1978), Vilar (2006) usou uma função hiperbólica para representar a influência da sucção mátrica na resistência ao cisalhamento, chegando a resultados satisfatórios com solos brasileiros. Foi então sugerida a equação 2.8:

$$
c=c^{\prime}+\frac{\psi}{(a+b \psi)}
$$

Onde:

c - intercepto coesivo;

$c^{\prime}$ - intercepto coesivo efetivo;

$\Psi$ - sucção;

$a$ e $b$ - parâmetros de ajuste da curva característica.

O parâmetro $a$ pode ser determinado para valores de sucção tendendo a zero, quando a relação entre a sucção e o intercepto coesivo atinge seu menor valor, tendo-se então:

$$
\begin{aligned}
& \left.\frac{d c}{d \psi}\right|_{\psi \rightarrow 0}=\frac{1}{a}=\operatorname{tg} \phi^{\prime} \\
& a=\frac{1}{t g \phi^{\prime}}
\end{aligned}
$$

Já quando a sucção tente a infinito, assume-se que a resistência ao cisalhamento atinge seu maior valor, tendo-se então $c_{u l t}$ ou $\tau_{u l t}$, de onde se tira o parâmetro $b$ :

$$
\lim _{\psi \rightarrow \infty} c=c_{u l t}=c^{\prime}+\frac{1}{b}
$$




$$
b=\frac{1}{c_{u l t}-c^{\prime}}
$$

Dados de Reis (2004), Futai (2002) e Escario (1988) foram usados para testar a aplicabilidade desta metodologia, também testada por Miao et al. (2001) e Georgetti (2010), chegando-se a resultados satisfatórios.

\section{2 \\ Solos residuais}

Os solos residuais são formados através da intemperização das rochas e permanecem em seu local de origem, sendo o grau de intemperismo variável com a profundidade. Quanto mais próximo da superfície, mais o material estará exposto às intempéries e mais modificado este será, ou seja, apresentará menos características da rocha-mãe.

Nos países tropicais, há uma prevalência do material residual, que, em consequência do clima ao qual estão submetidos, apresentam-se não saturados em campo e possuem alta permeabilidade, levando à conclusão de que suas propriedades de engenharia são facilmente afetadas pelas chuvas. De acordo com Brand (1985), a camada rochosa é intemperizada pela abundância de água (chuvas) e temperaturas relativamente elevadas, fundamentais nas mudanças químicas que sofrem as rochas de origem (Calle, 2000).

A morfologia do terreno também é importante na formação de solos residuais, pois pode contribuir para a infiltração e, consequentemente, para um maior fluxo de água através do maciço, favorecendo a ação dos processos de intemperismo e originando perfis de solo espessos, destacando-se os solos residuais jovens (Antunes et al., 2015).

Por conta destes fatores, os solos residuais são muito heterogêneos, o que dificulta a representatividade do maciço no processo de amostragem. É importante a definição do perfil de intemperismo, visto que cada camada terá características diferentes, tanto de resistência como de permeabilidade (Tabela 2.3). Para Guidicini e Nieble (1983) os perfis de intemperismo resultam de vários fatores, entre os principais a litologia, estrutura do maciço rochoso, topografia, variáveis climáticas locais e condições de percolação da água.

O solo coluvionar é originado por qualquer rocha-mãe transportada pela ação da gravidade, e apresenta muitas das suas características falando-se no 
contexto da engenharia. Como é comum o depósito de material coluvionar "cobrindo" o solo residual, a exemplo dos cones de despejo no pé de um talude, as vezes há uma dificuldade em dinstinguí-lo do solo residual (Calle, 2000).
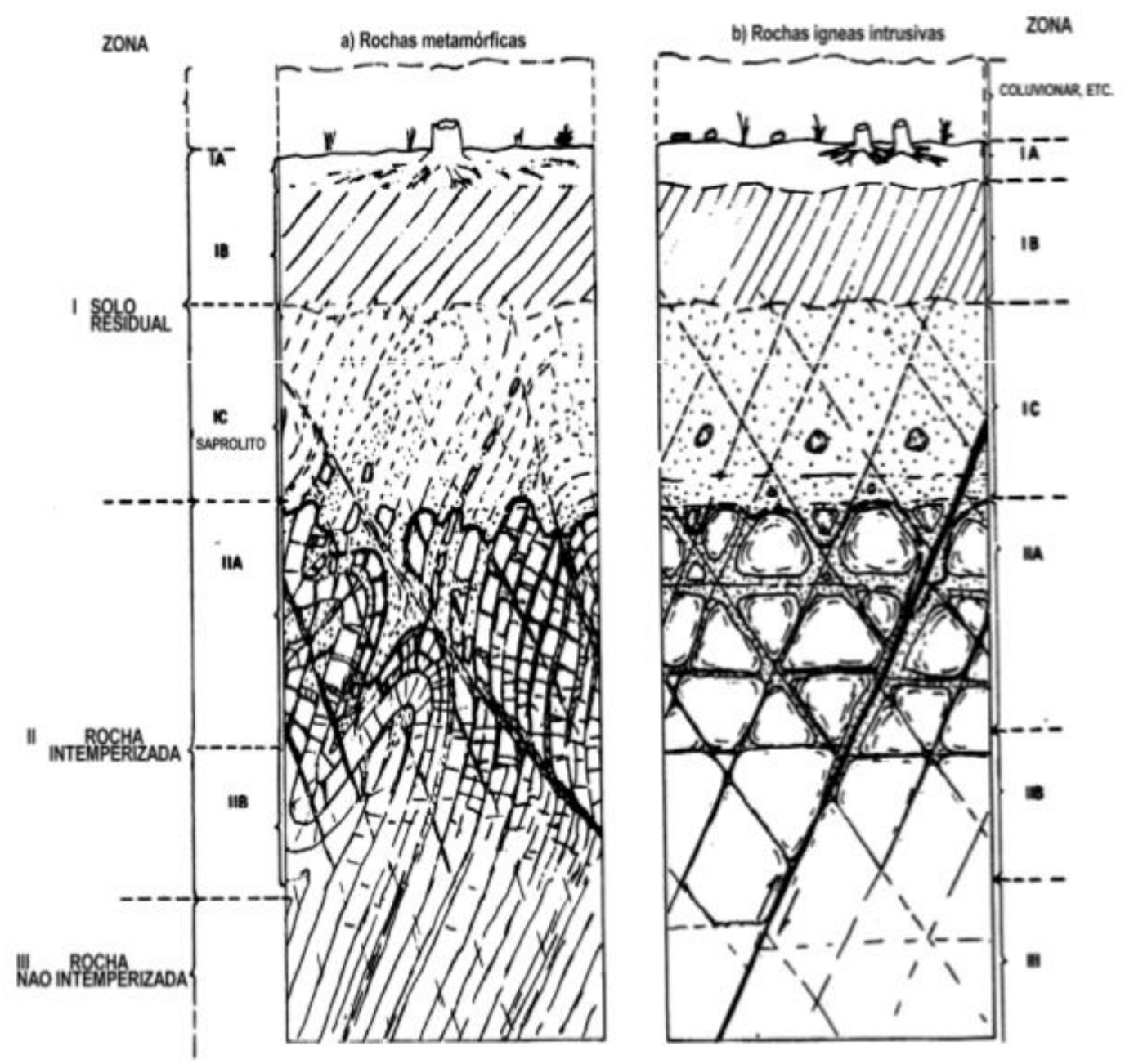

Figura 2.9 - Perfil de intemperismo para rochas metamórficas e ígneas intrusivas (Deere e Paton, 1971, apud Calle, 2000)

O processo de formação dos solos residuais resulta em características singulares nestes, dependentes da composição da rocha-mãe e do ambiente no qual foram desenvolvidos. São materiais relativamente frágeis e, geralmente, com baixo grau de cimentação. Como consequência, os conceitos básicos da mecânica dos solos clássica, fundamentados com base no comportamento de solos sedimentares de zonas temperadas, são inapropriados para descrever o comportamento tensão-deformação-resistência de solos residuais tropicais (Vaughan, 1988, apud Silva, 2017). 
Tabela 2.3 - Descrição das camadas de um perfil de intemperismo (Adaptado de Deere e Patton, 1971, apud Augusto Filho e Virgili, 1998)

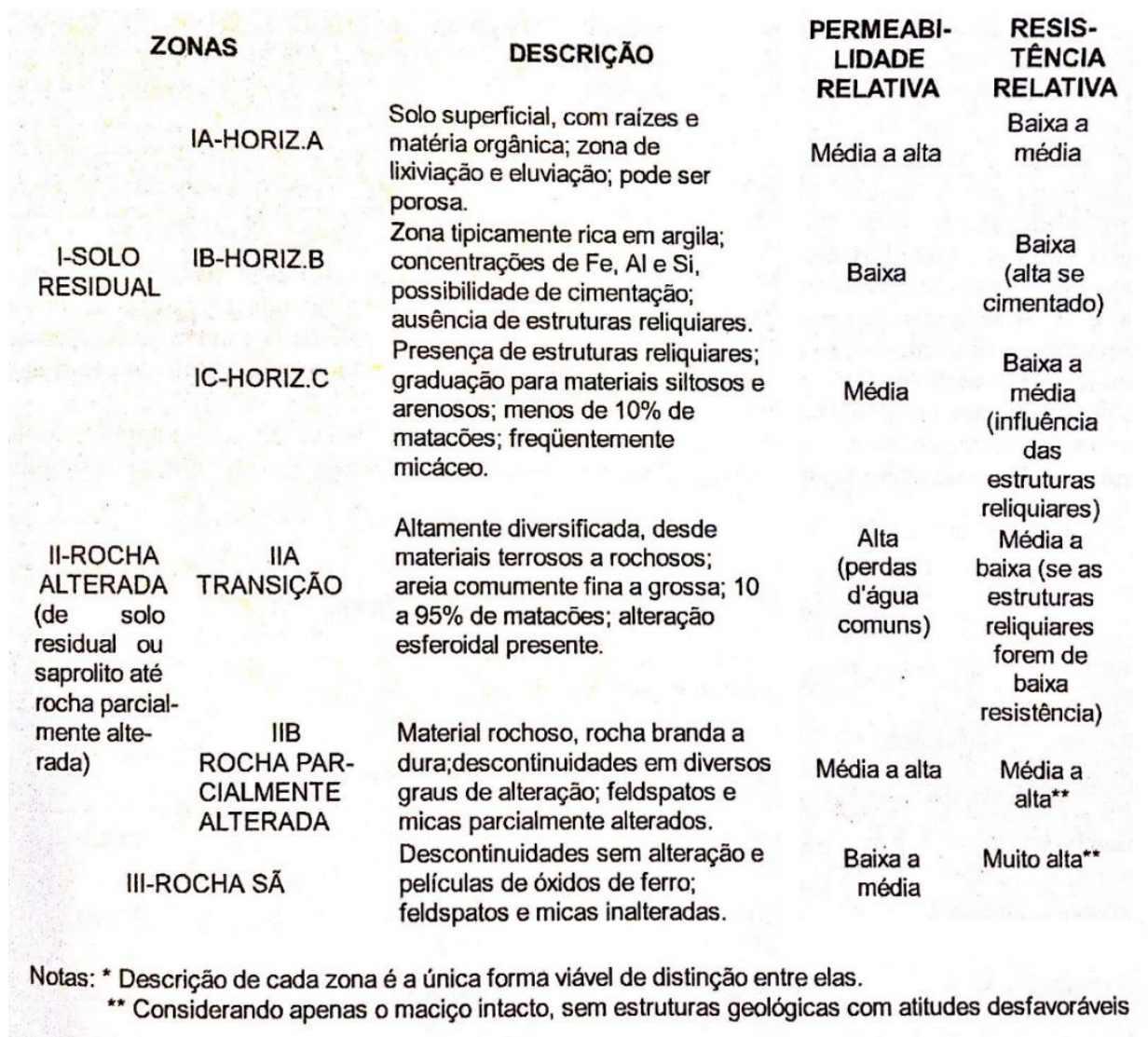

\section{3 \\ Estabilidade de taludes}

Define-se talude como qualquer superfície inclinada de um maciço de solo ou rocha, que pode ser natural, chamado também de encosta, ou executado pelo homem, como os aterros e cortes (Gerscovich, 2016).

Em diversas situações, como no projeto de estradas, túneis ou estruturas no subsolo, escavações, barragens de terra ou de rejeitos, e na prevenção de desastres ocasionados por deslizamos de terra, é necessária a análise da estabilidade de um talude, atribuindo-se para este um fator de segurança, que relaciona as forças resistentes com as atuantes.

Para isto, são realizados estudos que devem levar em conta a geologia, topografia, propriedades mecânicas do material, vegetação, clima e hidrologia, sendo o fator de segurança alterado de acordo com as mudanças que venham a ocorrer nestes fatores. 


\subsection{1}

\section{Movimentos de massa}

Taludes com baixo grau de segurança estão propensos a sofrer movimentos de massa, ou seja, a ter um volume de solo ou rocha deslocado. No Brasil, estes costumam ser vistos nos períodos de fortes chuvas, típicas de regiões de clima tropical. O relevo com inclinações acentuadas e a ocupação dos taludes, com a remoção da vegetação, depósito de lixo e escoamento de esgoto para o terreno, que modificam as condições naturais do talude, também são fatores que facilitam a ocorrência deste tipo de evento.

Guidicini e Nieble (1983) chamam atenção para os conceitos de agentes e causas de movimentos de massa (Tabela 2.4). Denomina-se como causa o modo de atuação de um agente, em outras palavras, um agente se expressa por uma ou mais causas. Por exemplo, o agente água tem influência na instabilidade de um talude pelo aumento na umidade do material não saturado, sendo a causa o aumento da poropressão.

Tabela 2.4 - Agentes e causas de movimentos de massa (Guidicini e Nieble, 1983, apud Santos, 2017)

\begin{tabular}{|c|c|c|c|}
\hline \multicolumn{4}{|c|}{ AGENTES/CAUSAS DOS ESCORREGAMENTOS } \\
\hline \multirow[t]{3}{*}{ AGENTES } & PREDISPONENTES & \multicolumn{2}{|c|}{$\begin{array}{l}\text { Complexo geológico, complexo morfológico, } \\
\text { complexo climático-hidrológico, gravidade, calor } \\
\text { solar, tipo de vegetação original }\end{array}$} \\
\hline & \multirow[t]{2}{*}{ EFETIVOS } & Preparatórios & $\begin{array}{l}\text { Pluviosidade, erosão pela água e } \\
\text { vento, congelamento e degelo, } \\
\text { variação de temperatura, } \\
\text { dissolução química, ação de } \\
\text { fontes e mananciais, oscilação } \\
\text { de nível de lagos, marés e do } \\
\text { lençol freático, ação de animais e } \\
\text { humana, inclusive } \\
\text { desflorestamento }\end{array}$ \\
\hline & & Imediatos & $\begin{array}{l}\text { Chuvas intensas, fusão do gelo e } \\
\text { neve, erosão, terremotos, ondas, } \\
\text { ventos, ação do homem }\end{array}$ \\
\hline \multirow[t]{3}{*}{ CAUSAS } & INTERNAS & \multicolumn{2}{|c|}{$\begin{array}{l}\text { Efeito das oscilações térmicas, redução dos } \\
\text { parâmetros de resistência por intemperismo }\end{array}$} \\
\hline & EXTERNAS & \multicolumn{2}{|c|}{$\begin{array}{l}\text { Mudança na geometria do sistema, efeitos de } \\
\text { vibração, mudanças naturais na inclinação das } \\
\text { camadas }\end{array}$} \\
\hline & INTERMEDIÁRIAS & \multicolumn{2}{|c|}{$\begin{array}{l}\text { Elevação do nível piezométrico em massas } \\
\text { "homogêneas", elevação da coluna da água em } \\
\text { descontinuidades, rebaixamento rápido do lençol } \\
\text { freático, erosão subterrânea retrogressiva } \\
\text { ("piping"), diminuição do efeito de coesão } \\
\text { aparente }\end{array}$} \\
\hline
\end{tabular}

Augusto Filho (1992) divide os tipos de movimentos de massa em rastejos, escorregamentos, quedas e corridas, conforme demonstrado na Tabela 2.5: 
Tabela 2.5 - Característcas dos tipos de movimento de massa (Augusto Filho, 1992)

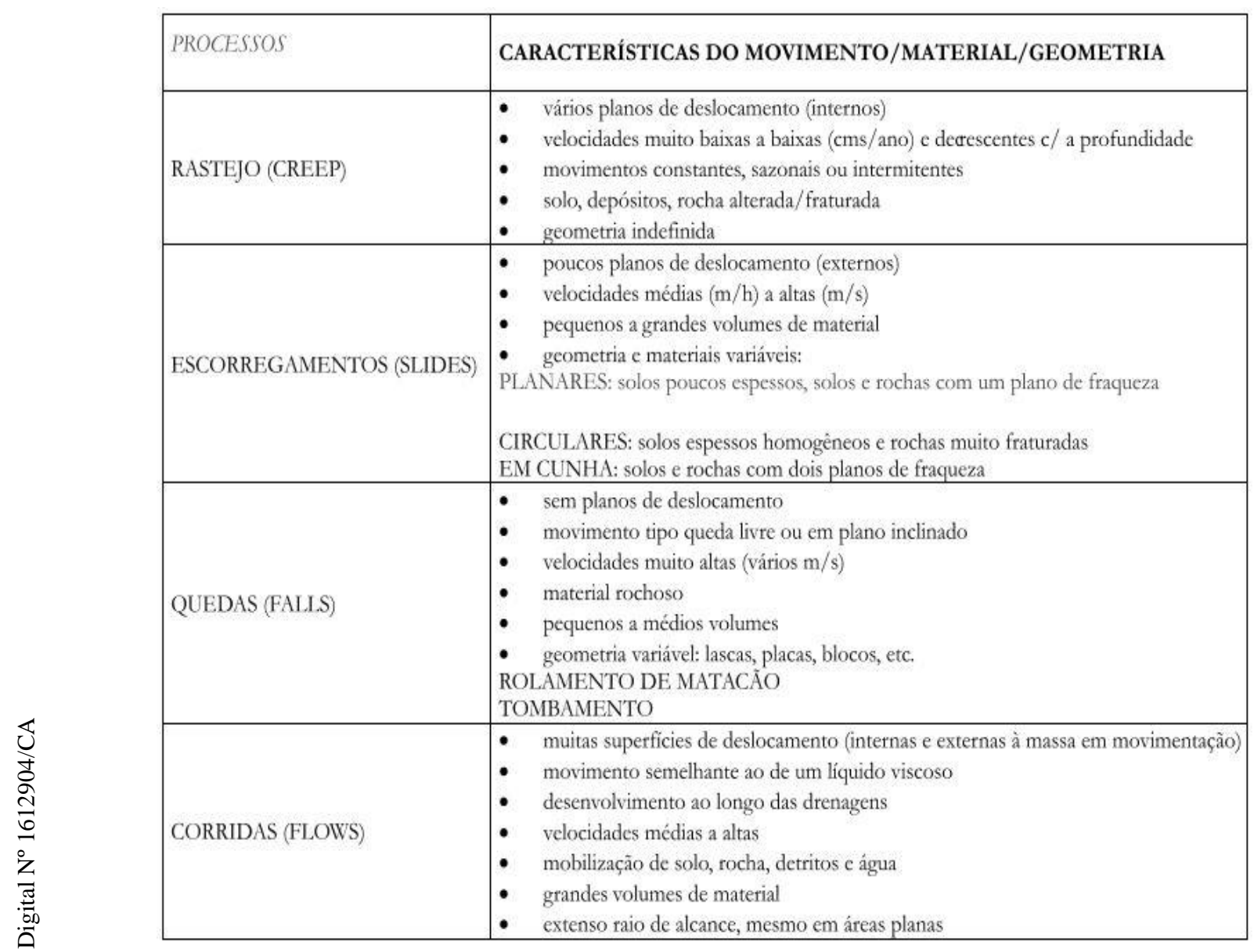

Dos movimentos de massa, Guidicini e Nieble (1983) definem como escoamento os movimentos contínuos, que podem apresentar ou não uma superfície de movimentação definida. Rastejos, escorregamentos e corridas são tipos de escoamentos, respectivamente do mais lento ao mais rápido.

Os rastejos ocorrem por ação da gravidade, associada aos efeitos das variações de temperatura e umidade, e podem envolver grandes massas. Como é um movimento lento e contínuo, seu progresso pode ser verificado através da formação de trincas no terreno e modificações na verticalidade e deslocamento de árvores, postes, cercas, etc.

Já os escorregamentos, são rápidos e de curta duração, com superfície de ruptura bem definida. Ocorrem na zona menos resistente do terreno, quando é atingida a resistência ao cisalhamento do material. Podem ser dividivos em planares, circulares ou em cunha. 
Os escorregamentos circulares (ou rotacionais), apresentam uma superfície de formato arredondado, e ocorrem em taludes mais íngremes, em solos espessos e rochas muito fraturadas. Os planares (ou translacionais) ocorrem em camadas de solo superficiais, ao longo de uma superfície plana. Classifica-se como escorregamento em cunha aqueles que se dão na interseção entre planos de fraqueza de rochas ou camadas não paralelas à superfície

Quando a estrutura do material é destruída, anulando sua resistência ao cisalhamento e com este se comportando como fluido, tem-se uma corrida. O principal fator para a ocorrência deste tipo de movimento são as águas acumuladas em chuvas intensas.

Nas quedas ou desabamentos, os blocos de rocha, que se desprendem do maciço através do intemperismo, vibrações, desconfinamento, entre outros fatores, caem por ação da gravidade, podendo ser através de rolamento ou tombamento.

\subsection{2 \\ Estabilidade de taludes de solos residuais}

Os deslizamentos de taludes naturais normalmente estão associados às épocas de chuvas intensas, ocorrendo no final da estação. Assim, as análises de estabilidade costumam ser realizadas baseando-se na teoria de que há um aumento na poropressão positiva através das redes de percolação. Porém, em muitos taludes de solos residuais, o nível d'água se localiza abaixo da superfície de ruptura, impedindo que o deslizamento seja explicado pelo mecanismo citado (Campos, 1984).

De acordo com Blight (1997), os taludes de solo residual geralmente parecem estáveis; porém este estado pode ser modificado por pequenos eventos na natureza ou intervenção humana. Estão associadas à sua instabilidade as precipitações longas e intensas, eventos sísmicos e intervenção antrópica.

Por serem solos não saturados, a estabilidade de solos residuais está associada ao nível de sucção ao qual este está submetido. De Campos (1997) apresentou a relação entre fator de segurança e sucção estabelecida por Ignacius et al. (1991) (Figura 2.10) para ilustrar que, mesmo para baixos valores desta, é possível manter estável uma encosta não saturada mesmo sob a infiltração de águas de chuvas. 


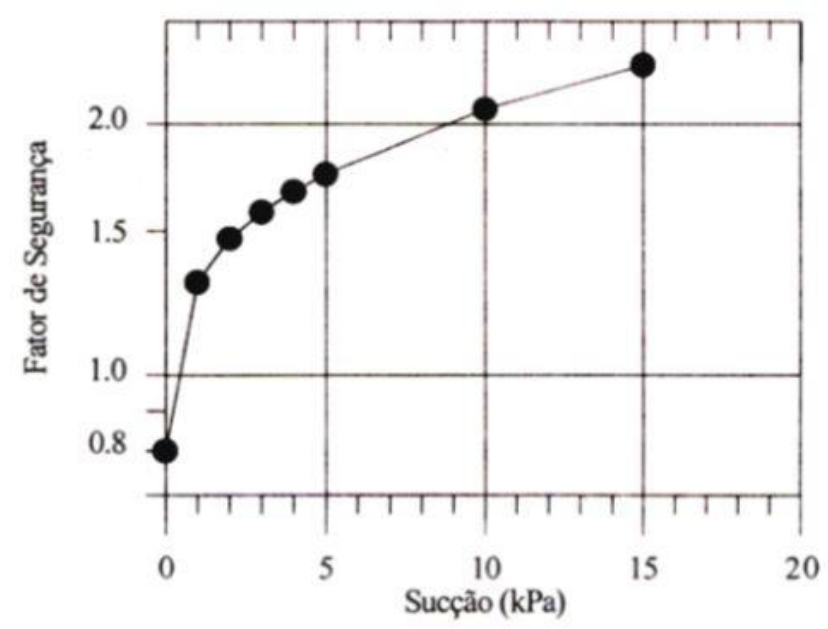

Figura 2.10 - Variação do fator de segurança de uma encosta não saturada com a sucção (Ignacius et al., 1991 apud De Campos, 1997)

O mecanismo de ruptura em solos residuais está quase sempre associado ao aumento de umidade devido à infliltração da água da chuva na zona vadosa, o que depende das propriedades hidráulicas do solo, do seu grau de saturação e da duração e intensidade da chuva (Santos, 2017). O aumento da umidade leva à redução da coesão aparente do solo, com consequente redução da resistência ao cisalhamento, resultando na instabilidade do talude.

De Campos et al. (2018) reuniram alguns outros mecanismos de ruptura que podem ser considerados em análises de estabilidade:

- Formação de linha freática transiente, pela infiltração de águas das chuvas, desaparecendo rapidamente no final do evento;

- Geração de poropressão positiva no contato solo-rocha, através de um caminho preferencial pelas fraturas para infiltração da água, que pode ocorrer por causas naturais ou interferência humana;

- Falha progressiva, associada à formação de poropressões positivas no subsolo, não estando necessariamente ligadas à ocorrência de fortes chuvas, como foi o caso da ruptura da Lagoa, RJ, em 2001.

Segundo Lumb (1975), a quantidade de água infiltrada nunca é capaz de saturar uma zona espessa de solo, com o efeito da precipitação limitando-se aos primeiros $6 \mathrm{~m}$ de profundidade, e a ação das águas das chuvas dependerá da duração e intensidade da precipitação, assim como da precipitação ocorrida anteriormente ao evento. 
A capacidade de infiltração de um solo está ligada à condutividade hidráulica na zona superficial e às condições de umidade. Assim, de acordo com a duração e intensidade da chuva e inclinação do talude, podem ser vistos casos em que toda a água é absorvida pelo solo e casos em que parte desse volume escorre superficialmente, chamado de runoff. Para chuvas mais longas, a capacidade de infiltração do solo irá diminuir, tornando a parcela de runoff mais significativa, conforme a Figura 2.11. Este costuma ser menor em áreas com vegetação mais densa e maior em áreas ocupadas (Gerscovich, 2016).

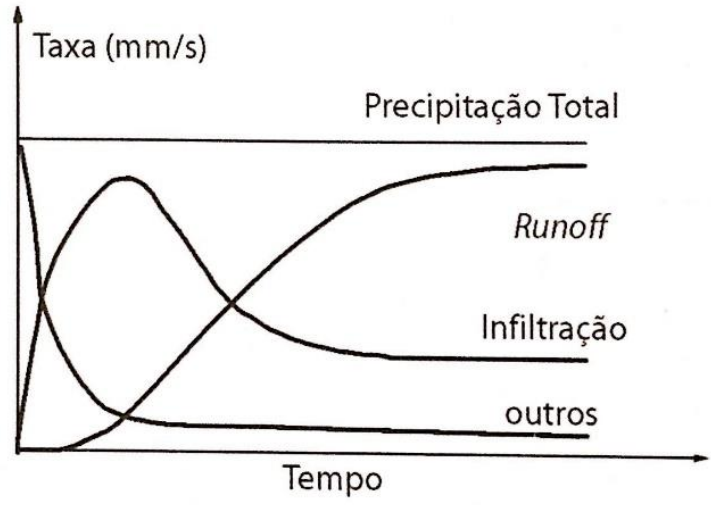

Figura 2.11 - Distribuição da taxa preciptada ao longo do tempo (Gerscovich, 2016)

A taxa de infiltração de um solo depende da sua condutividade hidráulica, capacidade de infiltração e intensidade da chuva. Ao dar-se início ao processo de infiltração, a princípio este ocorrerá mais rapidamente e mais próximo à superfície e depois avançará para regiões mais profundas e com menores velocidades (Figura 2.12).

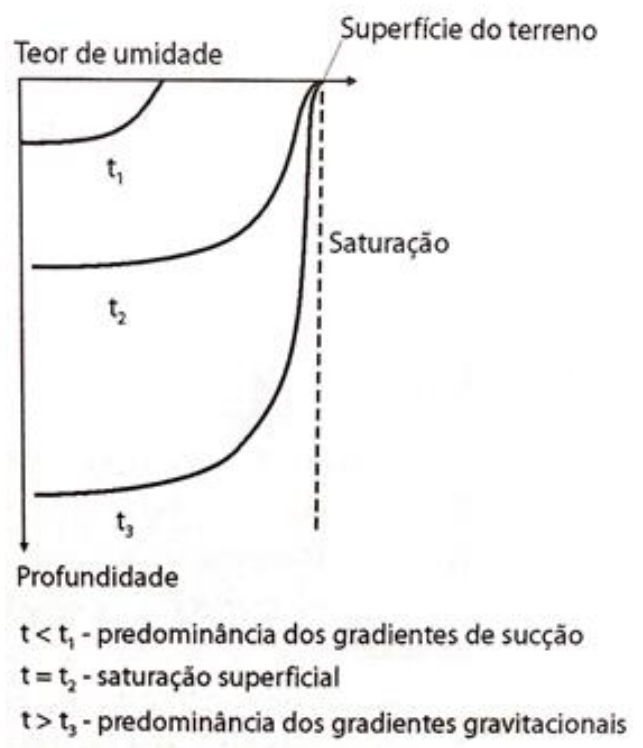

Figura 2.12 - Evolução de uma frente de saturação com o tempo (Gerscovich, 2016) 
A influência da vegetação na estabilidade de um talude de solo pode ser vista por duas vertentes. Mecanicamente, a vegetação contribui para a resistência ao cisalhamento através das raízes, que funcionam como reforço ao maçico. No ciclo hidrológico, a parcela de água que entra em contato com o solo e volta para a atmosfera, se dá, em parte, pela evapotranspiração das plantas; além destas absorverem parte da água infiltrada, reduzindo sua quantidade no solo (Campos, 1984). Ainda há a proteção contra os efeitos climáticos que esta exerce sobre o solo (Gerscovich et al., 2015).

A intervenção antrópica tem seu papel na instabilidade de taludes de forma indireta, sendo as ações cujas consequências são mais marcantes a remoção da vegetação, execução de cortes e aterros e o depósito de água e entulho (conforme mencionado no item 2.3.1), que tem como principais efeitos as mudanças nas condições de infiltração e geometria do talude, aumento da tensão solicitante por sobrecarga e redução na resistência ao cisalhamento.

\subsection{3}

\section{Análise de estabilidade}

A análise de estabilidade visa avaliar o grau de estabilidade de um talude, indicando a possibilidade de ocorrência de movimentos de massa.

De acordo com Augusto Filho e Virgili (1998), os métodos de análise de estabilidade estão dividos em três grupos:

- Métodos observacionais: As análises são realizadas com base na experiência aculumada de análises anteriores, através de ábacos de projeto, opiniões de especialistas, retroanálises, etc.

- Métodos experimentais: Utilizam-se Modelos físicos dos taludes equivalentes em pequena escala.

- Métodos analíticos: Baseados na teoria do equilíbrio limite, a qual obtém um fator de segurança (abordagem determinística) ou a probabilidade de ruptura para o talude (abordagem probabilística); ou na relação tensão $x$ deformação dos materiais do talude.

Geralmente, as análises de estabilidade são feitas por métodos de equilíbrio limite, que considera que as forças atuantes são balanceadas pelas resistentes, avaliando a estabilidade global do talude. Um fator de segurança igual à unidade 
representa a condição de equilíbrio limite, devendo ser maior que 1 para que o talude esteja estável (equação 2.13).

$$
F S=\frac{\text { Forças resistentes }}{\text { Forças atuantes }}
$$

Apesar de não levar em consideração o comportamento tensão $x$ deformação do solo, sua formulação simplificada e não abordar a variabilidade dos parâmetros do material; este método apresenta bons resultados, sendo capaz de reproduzir satisfatoriamente situações reais. Gidicini e Nieble (1983) justificam seu uso na afirmação de que a análise não deve ser mais complexa que o nível de conhecimento do próprio talude. Assim, para a obtenção de bons resultados, é necessário que sejam obtidos dados confiáveis e de qualidade do talude e do material que o compõe.

Segundo Abramson et al. (2001), os métodos de análise de estabilidade baseados na teoria do equilíbrio limite mais utilizados dividem o maciço em fatias, como ilustra a Figura 2.13. Em cada uma, há a atuação de um sistema de forças. Os mais difundidos são os de Fellenius (1936), Bishop simplificado (1955), Janbu simplificado (1954) e generalizado (1973), Morgenstern e Price (1965), Spencer (1967) e Sarma (1973).

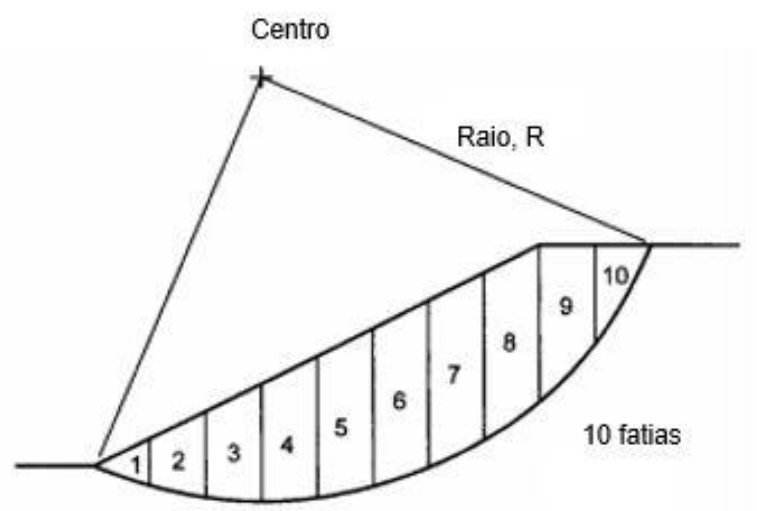

Figura 2.13 - Divisão da superfície de ruptura potencial em fatias (adaptado de Abramson et al., 2001)

A superfície de ruptura é dividida em fatias e são aplicadas as hipóteses de que esta é bem delimitada; o fator de segurança é o mesmo para todas as fatias; o critério de Mohr-Coulomb é satisfeito e a ruptura é generalizada. O fator de segurança então será obtido através do equilíbrio de forças horizontais, verticais e/ou momentos em cada fatia (Figura 2.14), cada método com sua proposta. 
Quanto maior a quantidade de fatias, menor será a espessura de cada uma e, consequentemente, mais precisos serão os resultados.

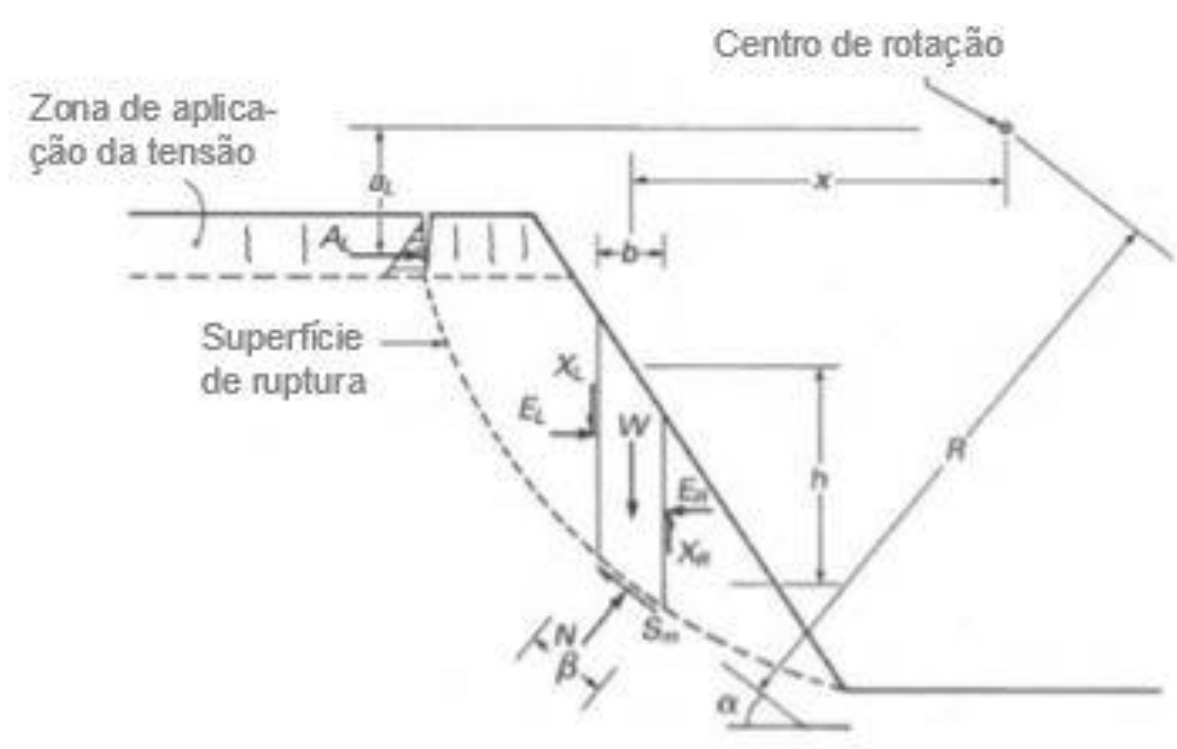

Figura 2.14 - Forças atuantes em uma fatia (adaptado de Fredlund et al., 2012)

Sendo:

$W$ - peso da fatia;

$N$ - força normal na base da fatia;

$S_{m}$ - força cisalhante mobilizada na base da fatia;

$E_{L}, E_{R}$ - componente horizontal das forças entre fatias;

$X_{L}, X_{R}$ - componente vertical das forças entre fatias;

$A_{L}$ - força hidrostática exercida pela água que preenche a trinca;

$a_{L}$ - distância perpendicular entre a linha de ação da resultante hidrostática e o centro de rotação dos momentos;

$\alpha$ - ângulo entre a reta tangente ao centro da base da fatia e a horizontal;

$h$ - distância vertical entre o centro da base da fatia para o centro do topo da fatia;

$b$ - largura da fatia;

$x$ - distância horizontal entre a linha de ação do peso da fatia e o centro de rotação dos momentos;

$\beta$ - comprimento da base da fatia.

A força resistente mobilizada, para um solo saturado, é dada pela equação 2.14:

$S_{m}=\frac{\beta}{F S}\left(c^{\prime}+\sigma^{\prime} \operatorname{tg} \phi^{\prime}\right)$ 
A análise de estabilidade por métodos de equilíbrio limite é realizada através de suposições que intencionam reduzir o número de incógnitas, que será o mesmo de equações de equilíbrio. Porém, nem todos eles satisfazem as mesmas condições. O método generalizado de Jambu e Morgenstern e Price satisfazem todas as condições de equilíbrio, com duas equações de equilíbrio de forças (horizontais e verticais) e uma de momento para cada fatia, com $3 \mathrm{~N}$ equações (sendo $\mathrm{N}$ o número de fatias). O método de Bishop simplicado não satisfaz o equilíbrio de forças horizontais, enquanto o de Fellenius não promove o equilíbrio em todas as fatias (Calle, 2000). O método de Janbu simplificado faz uso apenas do equilíbrio de forças horizontais, gerando fatores de segurança menos confiáveis.

Sarma propôs um método tão rigoroso quanto o de Morgenstern e Price, com a vantagem de não requisitar um programa de computador para resolver o problema, bastando ter-se em mãos uma calculadora ou uma planilha eletrônica para se obter o fator de segurança (Fabrício, 2006).

Os métodos de Spencer e Morgenstern e Price se diferenciam basicamente pela superfície ruptura (o primeiro considera circular e o segundo qualquer) e pela inclinação da resultante da força de contato entre as fatias (respectivamente, constante e variável). Neste trabalho, será utilizado o método de Morgenstern e Price, por ser o mais completo entre os disponíveis nos programas atuais.

Para a avaliação de eventos já ocorridos, é utilizada uma técnica denominada de retroanálise, que tem como finalidade avaliar as condições que levaram o fator de segurança se igualar à unidade, ou seja, procedimento contrário à análise convencional. Considera-se que os parâmetros de resistência devem satisfazer a situação em que FS=1 na superfície crítica.

\subsubsection{1}

\section{Método de Morgenstern e Price}

É um método rigoroso de equilíbrio limite para uma superfície de ruptura qualquer, cujas condições de equilíbrio de forças (verticais e horizontais) e momentos são satisfeitas. A inclinação da força resultante enre as fatias infinitesimais $\left(\theta_{\text {res }}\right)$ e a horizontal é calculada por uma função arbitrária $f(x)$, que estabelece uma relação entre as componentes normal $(E)$ e tangencial $(T)$, variando ao longo da superfície de ruptura em uma distância $x$. Este artifício é usado para que o problema se torne determinado.

Tem-se então as equações 2.15 e 2.16 : 


$$
\begin{aligned}
& T=\lambda f(x) E \\
& \operatorname{tg} \theta_{\text {res }}=\frac{T}{E}=\lambda f(x)
\end{aligned}
$$

Onde $\lambda$ é um fator escalar obtido pela solução do fator de segurança.

Com base no equilíbrio de forças horizontais e verticais e no critério de Mohr-Coulomb, chega-se à equação para o cálculo de $E$. O equilíbrio de momentos $(M)$ deve considerar que a soma destes no centro da base é nula, para que não haja rotação da fatia.

A solução do problema é encontrada atribuindo-se valores para FS e $\lambda$ e calculando-se $E(x)$ e $M(x) . f(x)$ pode ser constante, trapezoidal, senoidal ou outra forma qualquer. São feitas diversas interações, até que se encontre um mesmo valor para o fator de segurança para as equações dos equilíbrios de forças $\left(F S_{f}\right)$ e momentos $\left(F S_{m}\right)$, satisfazendo as condições de contorno.

\subsubsection{2}

\section{Contribuição da sucção}

Para os solos não saturados, a análise de estabilidade deve contar, ainda, com a parcela da resistência ao cisalhamento associada à sucção, acrescentando a parcela referente à $\phi^{b}$ da equação 2.6. Considera-se, então, a influência das poropressões positiva e negativa na resistência ao cisalhamento.

A força cisalhante mobilizada em cada fatia (Figura 2.14) será dada pela equação 2.17, baseando-se na equação de Fredlund et al. (1978):

$$
S_{m}=\frac{1}{F S}\left[c^{\prime}+\left(\sigma-u_{a}\right)_{r} \operatorname{tg} \phi^{\prime}+\left(u_{a}-u_{w}\right)_{r} \operatorname{tg} \phi^{b}\right] \beta
$$

Assumindo-se que $u_{a}=0$ (pressão atmosférica), a força normal na base de uma fatia é dada por:

$$
\begin{aligned}
& N=\frac{W-\left(X_{L}-X_{R}\right)-\frac{C^{\prime} \beta \operatorname{sen} \alpha}{F S}+u_{a} \frac{\beta \operatorname{sen} a}{F S}\left(\operatorname{tg} \phi^{\prime}-\operatorname{tg} \phi^{b}\right)+u_{w} \frac{\beta \operatorname{sen} a}{F S} \operatorname{tg} \phi^{b}}{m_{a}} \\
& m_{a}=\cos \alpha+\frac{F S}{\operatorname{sen} \alpha \operatorname{tg} \phi^{\prime}}
\end{aligned}
$$


Fredlund e Krahn (1977) apresentaram as equações 2.20 e 2.21 para o cálculo do fator de segurança a partir do equilíbrio de forças e momentos para um solo não saturado:

$$
\begin{aligned}
& F S_{f}=\frac{\sum\left[c^{\prime} \beta \cos \alpha+\left(N-u_{w} \beta \frac{\operatorname{tg} \phi^{b}}{\operatorname{tg} \phi^{\prime}}\right) \operatorname{tg} \phi^{\prime} \cos \alpha\right]}{A_{L}+\sum N \operatorname{sen} \alpha} \\
& F S_{m}=\frac{\sum\left[c^{\prime} \beta R+\left(N-u_{w} \beta \frac{\operatorname{tg} \phi^{b}}{\operatorname{tg} \phi^{\prime}}\right) R \operatorname{tg} \phi^{\prime}\right]}{A_{L} a_{L}+\sum W x-\sum N f}
\end{aligned}
$$

O equilíbrio de momentos é satisfeito a partir de um ponto arbitrário acima do centro da superfície de ruptura, sendo o centro de rotação para uma superfície circular o mesmo que o dos momentos. Para o equilíbrio de forças, utiliza-se a função arbitrária do método de Morgenstern e Price (equação 2.15) para relacionar as componentes normal e tangencial da força resultante entre fatias.

As análises de estabilidade de taludes que incluem a influência da poropressão negativa podem ser formuladas como uma extensão das análises de equilíbrio limite convencional. Vários aspectos do estudo saturado permanecem os mesmos para o não saturado, porém, são necessárias extensões dos ensaios tradicionais para a caracterização de resistência ao cisalhamento do solo, podendo ser utilizados os procedimentos de estimativa para aproximar a envoltória não saturada. As ferramentas analíticas usadas para incorporar a poropressão no cálculo do fator de segurança necessitam de ampliação para abranger o comportamento não saturado (Fredlund et al., 2012). 


\section{3 \\ Área de Estudo}

\section{1 \\ Localização}

A área em estudo, localiza-se no Centro Histórico de Salvador/BA, no bairro do Santo Antônio Além do Carmo, identificada nas Figuras 3.1 e 3.2. É um dos bairros mais antigos da cidade, destacando-se suas construções antigas, de arquitetura colonial, igrejas, entre outros monumentos históricos.

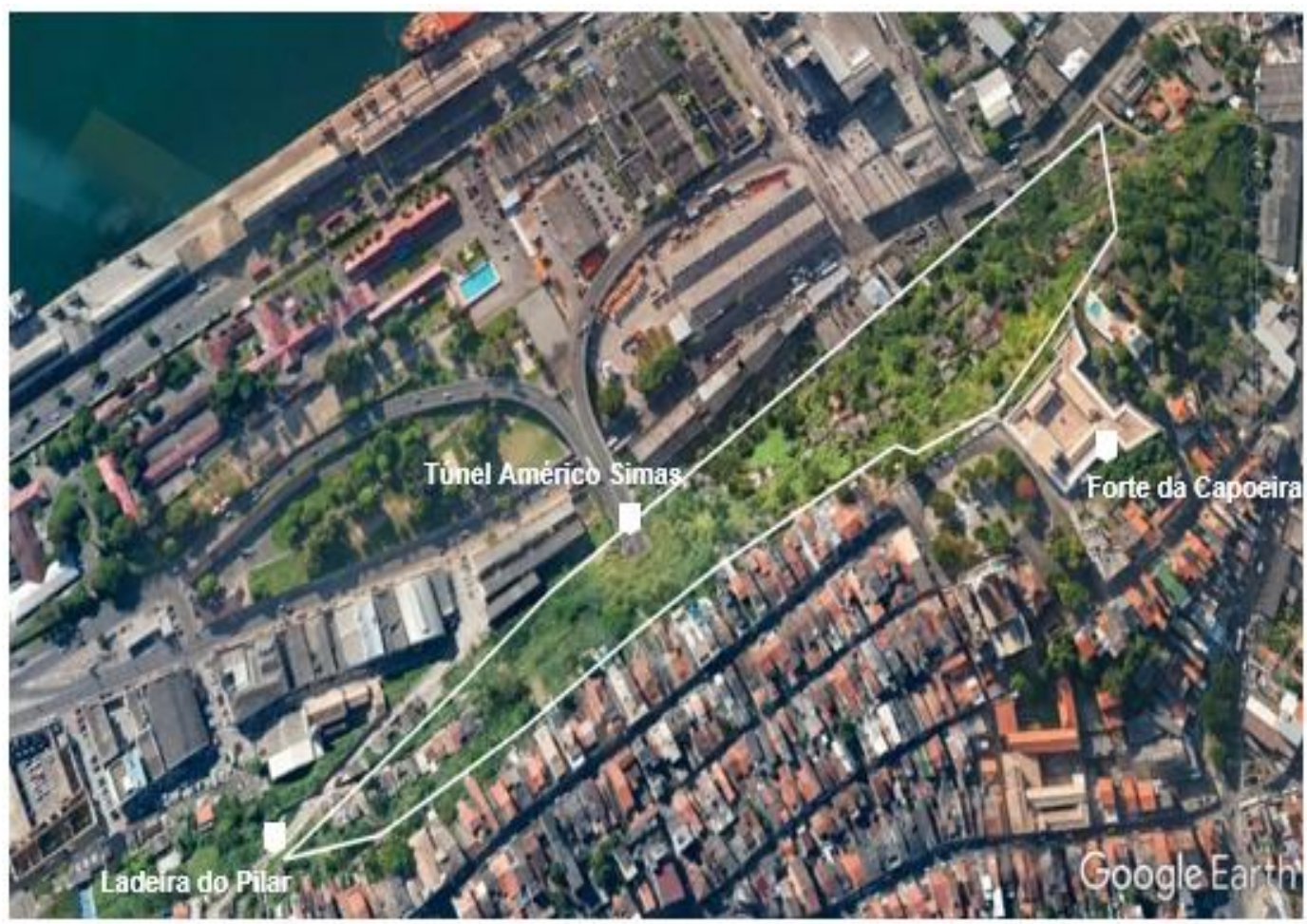

Figura 3.1 - Localização da área de estudo 


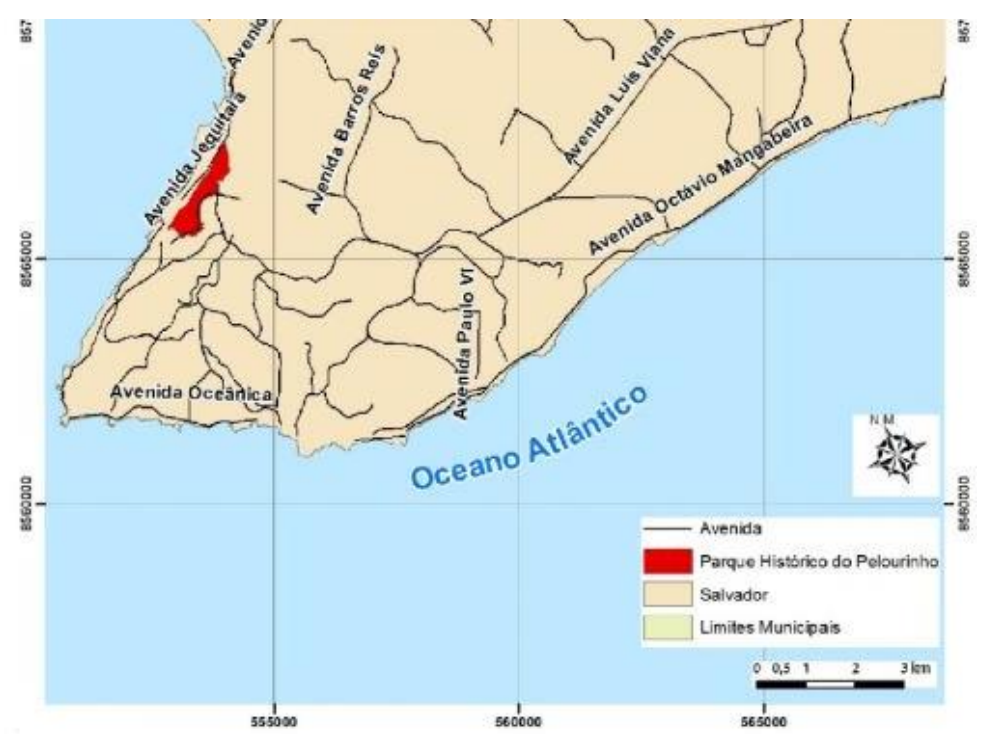

Figura 3.2 - localização do Centro Histórico de Salvador (Ribeiro, 2011)

\section{2}

\section{Aspectos geológicos, geomorfológicos e hidrológicos}

O Plano Diretor de Encostas de Salvador (PDE) (PMS, 2004) divide o sítio urbano da cidade em 5 unidades informais, chamadas de Domínios GeológicoGeotécnicos, estando a área em estudo localizada no domínio denominado Escarpa da Falha de Salvador, dividindo-a em Cidade Alta e Cidade Baixa (Figura 3.3)

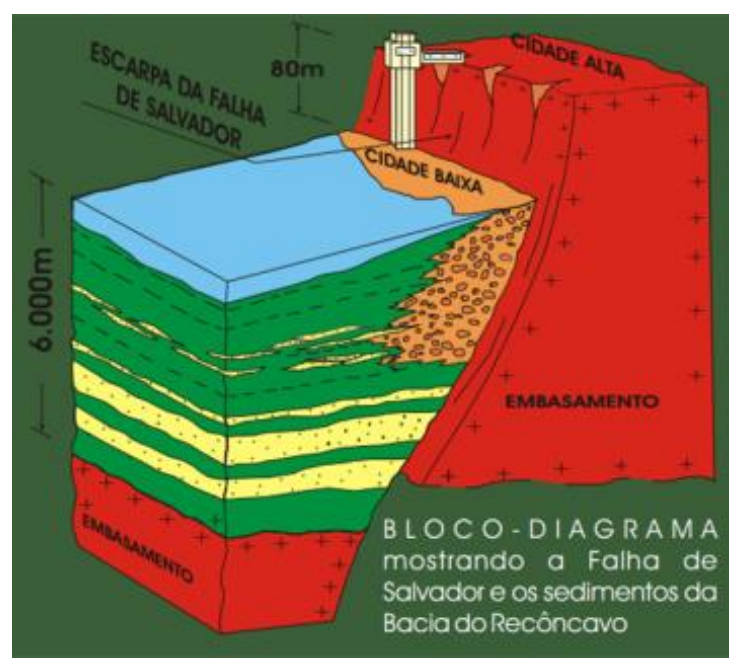

Figura 3.3 - Esquema da falha de Salvador (Projeto Caminhos Geológicos da Bahia, 2004)

Segundo Correia et al. (2009), sua origem está associada à abertura de instalação do rift da Bacia do Recôncavo durante o período Mesozóico. Sua elevada declividade proporciona instabilidade, principalmente, nas encostas desnudadas 
ou nas áreas com infraestrutura urbana precária, favorecendo os movimentos de massa.

Esse domínio é descrito como um compartimento geológico-geotécnico composto por rochas do embasamento cristalino da falha e rochas sedimentares da Bacia do Recôncavo, as primeiras relacionadas à área de estudo. A encosta ou escarpa foi esculpida a partir da erosão do bloco alto da Falha de Salvador. O maciço rochoso apresenta pelo menos 5 famílias de fraturas que segmentam a rocha, formando um padrão de descontinuidades intercruzadas com predominância das fraturas com mergulho elevado (PMS, 2004).

A rocha local, classificada como granulito-gnaisse, geralmente se encontra coberta por uma média de 10 a 20m de camada de solo residual com cor amarronzada a amarelada e de composição areno-argilosa, argilo-siltosa ou argilo-arenosa, com a camada superficial composta por material colvionar ou aterro. Este pode ser visto, por vezes, sustentando matacões e/ou exposições da rocha. $\mathrm{Na}$ maioria das vezes, a estrutura original da rocha mãe está preservada, sendo possível observar veios de quartzo, ou grãos de feldspato alterados para caulim. (Correia et al., 2009; PMS, 2004).

As figuras 3.4 e 3.5 exibem os diferentes materiais identificados no local. Observou-se a presença de minerais félsicos nos afloramentos de rocha encontrados, associados com a rocha-mãe da área.
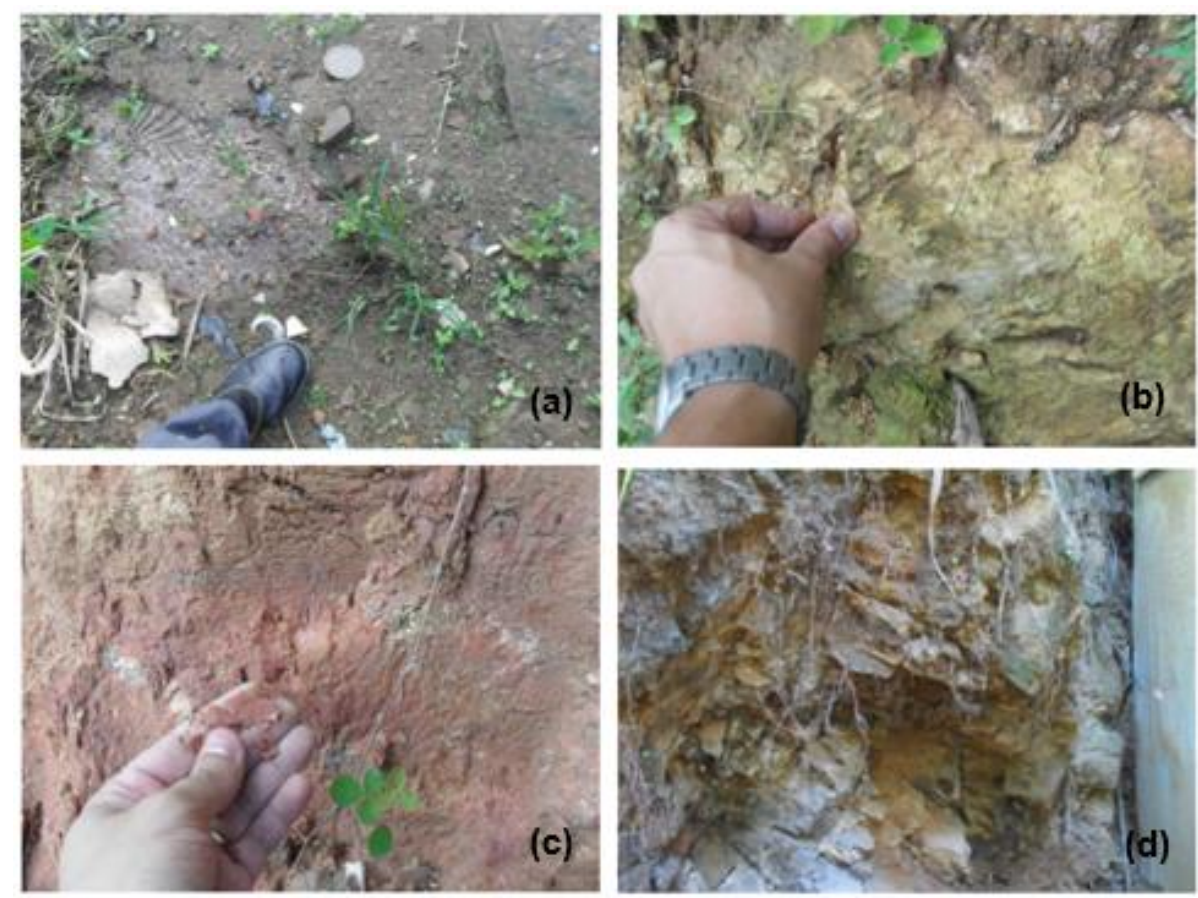

Figura 3.4 - Aspecto dos materiais visualizadas no local: (a) camada superficial, provável aterro, (b) e (c) solo residual e (d) rocha fraturada (Geoeng, 2014) 

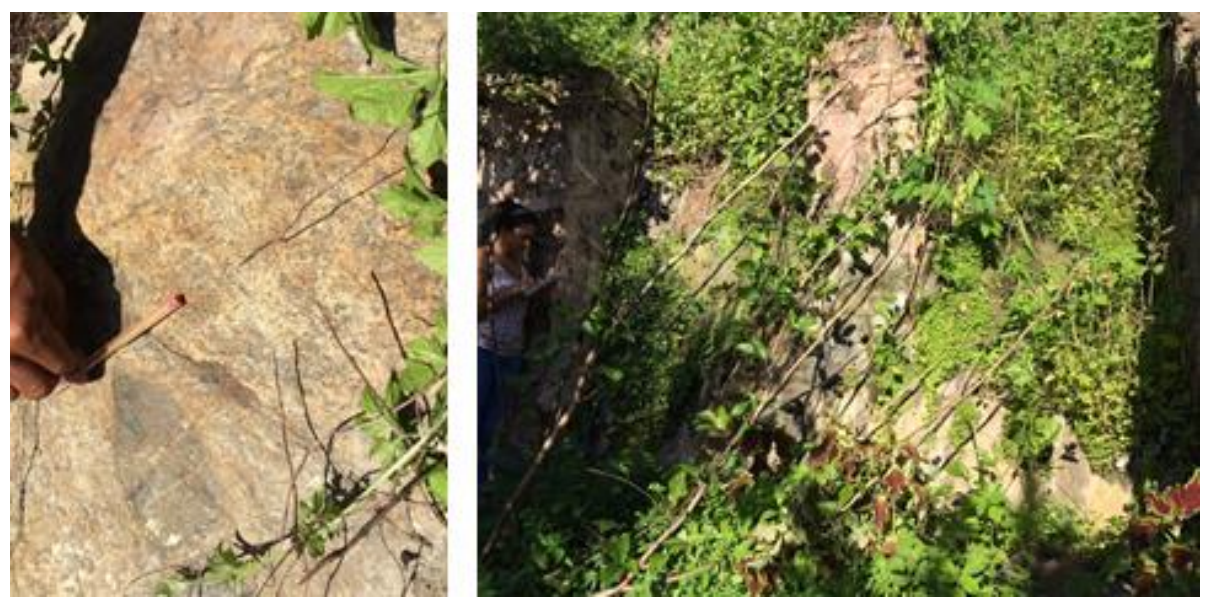

Figura 3.5 - Afloramento de rocha no pé do talude

O PDE (PMS, 2004) localiza o Santo Antônio Além do Carmo na unidade geomorfológica do Planalto Dissecado no Embasamento Cristalino, caracterizada principalmente pela presença de morros, vales e colinas. Entre os processos morfodinâmicos mais atuantes, estão o escoamento superficial difuso e concentrado, infiltração e a erosão provocada pela ação do homem. Há uma tendência à instabilidade dos taludes que são desprovidos de drenagem superficial e/ou de contenções, com a presença de sulcos e ravinas (Figura 3.6).

Observou-se que o local com maior número de eventos de escorregamentos do terreno está associado às áreas de ocorrência desta unidade, com destaque para a Chácara Santo Antônio, onde inclusive foi registrado um número significativo de casas com rachaduras, indicativas de movimentações do terreno. Observou-se também a ocorrência de ravinas nesta unidade, em locais onde foi constatada a retirada de vegetação (Correia et al., 2009).

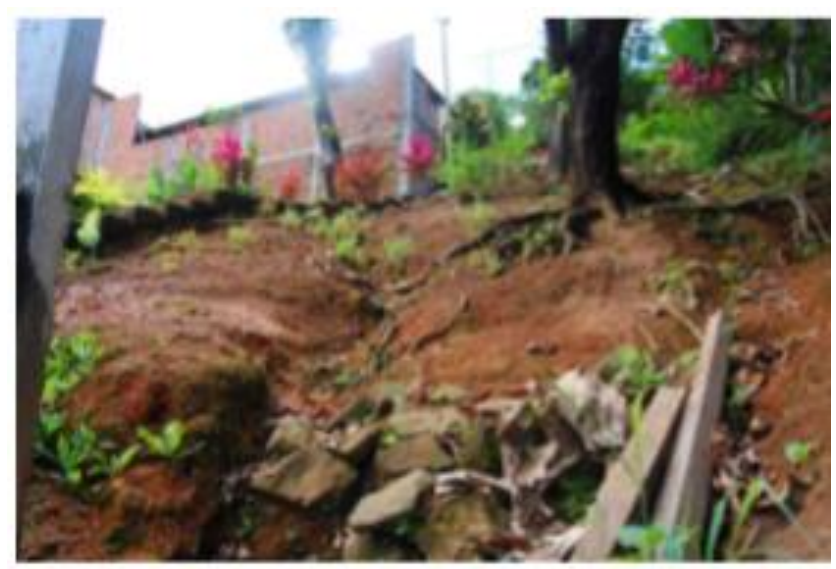

Figura 3.6 - Presença de ravinas no terreno (Correia et al., 2009)

Quando aos aspectos hidrológicos, a área de estudo apresenta apenas alguns minadouros naturais e pequenas fontes, que aparecem como resultado da 
interseção do nível hidrostático com a escarpa da falha. A água lançada pelas casas das comunidades que ocupam o talude (que possuem um sistema de esgotamento precário) juntamente com a água da chuva, infiltra no solo e se mistura com a água subterrânea que circula pelas fraturas do maciço, criando um cenário favorável à sua saturação (Geoeng, 2014).

De acordo com o PDE (PMS, 2004), dois mecanismos de ruptura, associados aos fatores listados anteriormente, são esperados na região:

- Ruptura não circular em fatias no saprólito/solo quando, além das fissuras de tração, o sistema de fraturas do embasamento cristalino influencia o mecanismo;

- Ruptura circular rasa nas proximidades do contato entre o solo residual jovem e o solo residual maduro.

\section{3}

\section{Aspectos climáticos}

A cidade apresenta clima tropical úmido a superúmido, com umidade relativa do ar média de $85 \%$ (não variando significativamente durante o ano) e temperatura variando entre $21^{\circ} \mathrm{C}$ e $31^{\circ} \mathrm{C}$ durante o ano, entre mínimas e máximas, segundo dados do INMET (Instituto Nacional de Meteorologia) e Climate-Data (Figura 3.7). Normalmente, os meses com maior índice pluviométrico são os de abril a junho, sendo os meses de dezembro a fevereiro os mais secos.

Em novembro de 2011, uma chuva atípica, fora de época, atingiu a cidade, com uma precipitação de quase $200 \mathrm{~mm}$ em 48h, como mostra a Figura 3.8, quando ocorreu o evento aqui estudado, levando a entender que o mecanismo de ruptura do talude está relacionado com o alto índice pluviométrico. Apesar dos altos índices mensais do período de chuvas típico, estas ocorreram de forma distribuída entre os dias, não tendo sido vistas durante o ano chuvas tão intensas ocorrendo em dois dias seguidos como as citadas.

A Figura 3.9 mostra as precipitações médias mensais na cidade dos últimos 20 anos, de onde é possível se identificar os períodos de chuva e de seca. Comparando esta com as chuvas mensais de 2011 da Figura 3.10, percebe-se que foi um ano de precipitações incomuns, principalmente para o mês de novembro, cujo alto índice se deve às chuvas dos dias 8 e 9. 


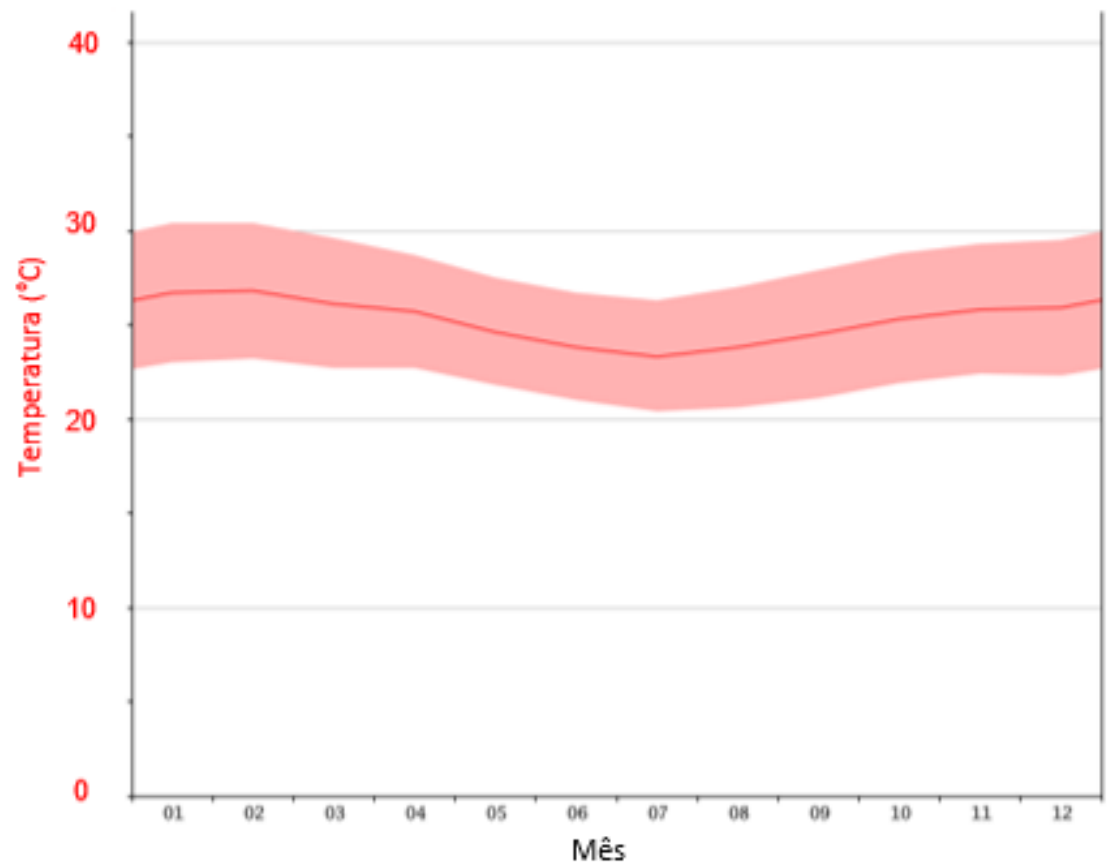

Figura 3.7 - Temperaturas máximas, mínimas e médias anuais em Salvador (Adaptado de Climate-Data)

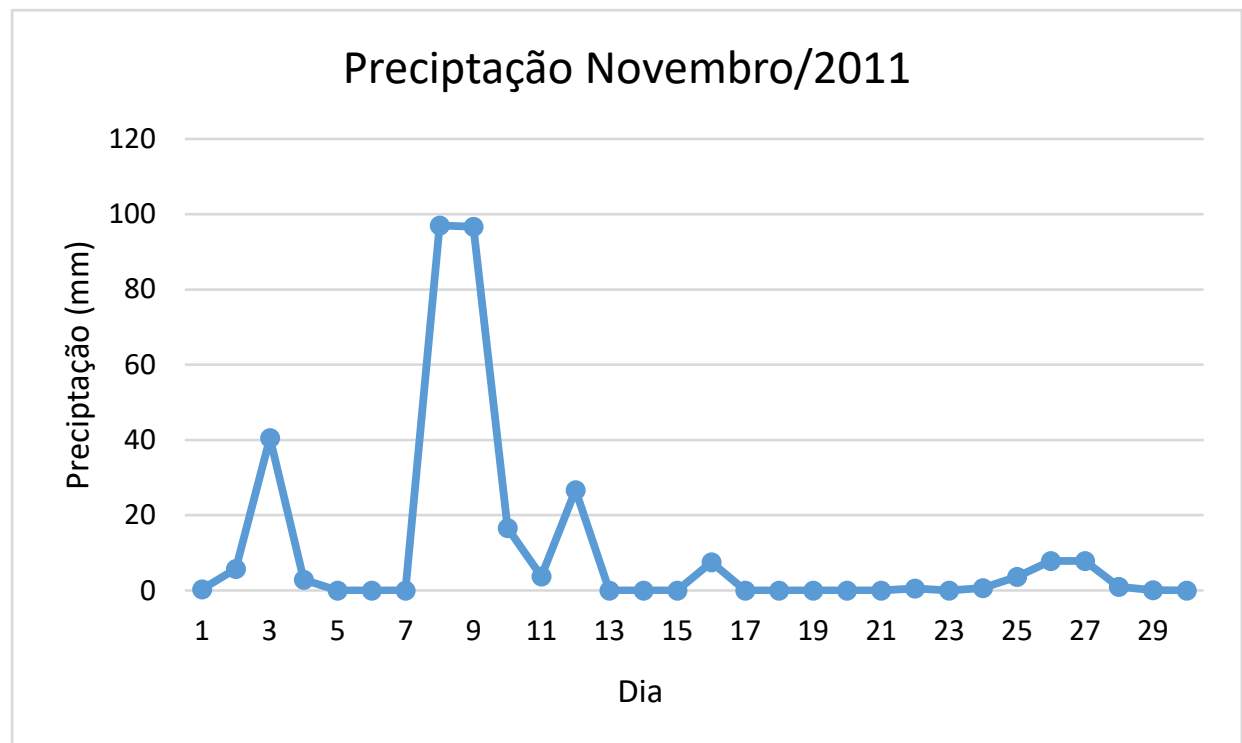

Figura 3.8 - Preciptação diária de novembro de 2011 (INMET) 


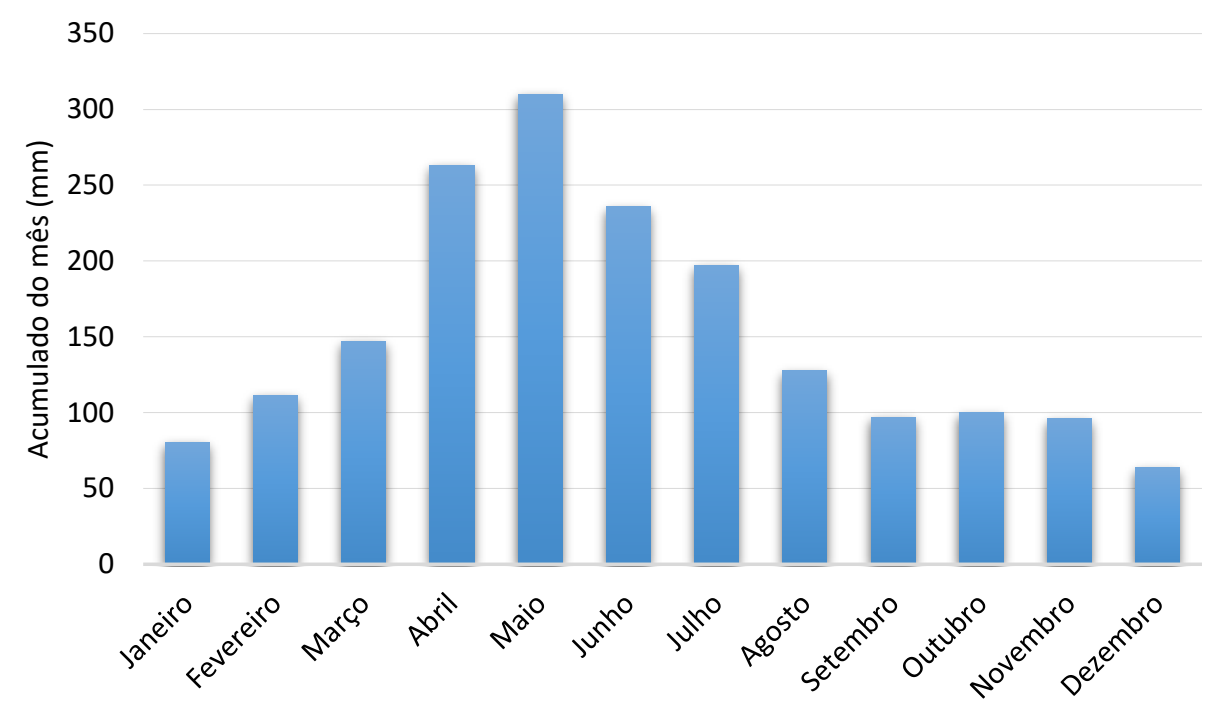

Figura 3.9 - Preciptação média mensal de Salvador dos últimos 20 anos (INMET)

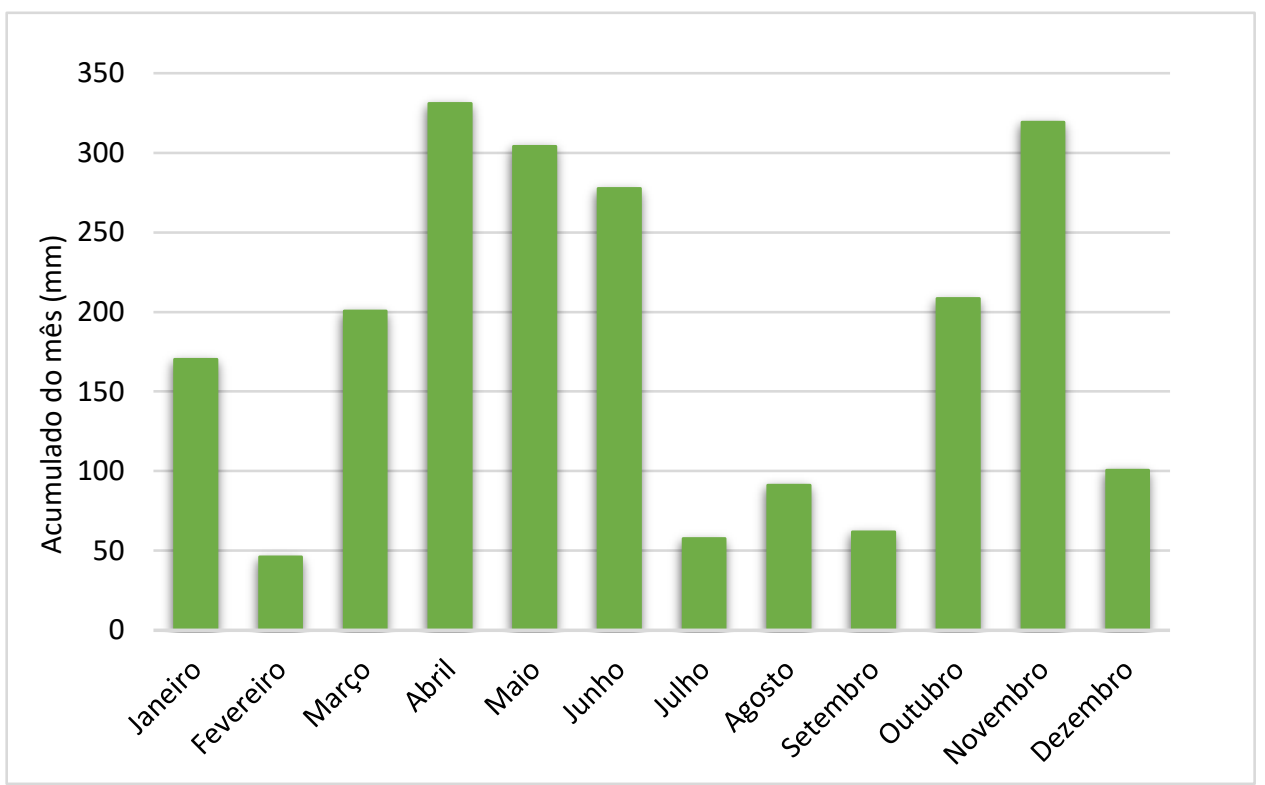

Figura 3.10 - Preciptação mensal de 2011 (INMET)

\section{4}

\section{Vegetação}

Predomina a vegetação rasteira (gramínea e arbustiva), sendo também vistas árvores frutíferas, como abacateiros, mangueiras e bananeiras, esta última sendo um fator negativo em relação à estabilidade do talude, por conta de sua capacidade de armazenar água. A Figura 3.11 ilustra a vegetação local. 


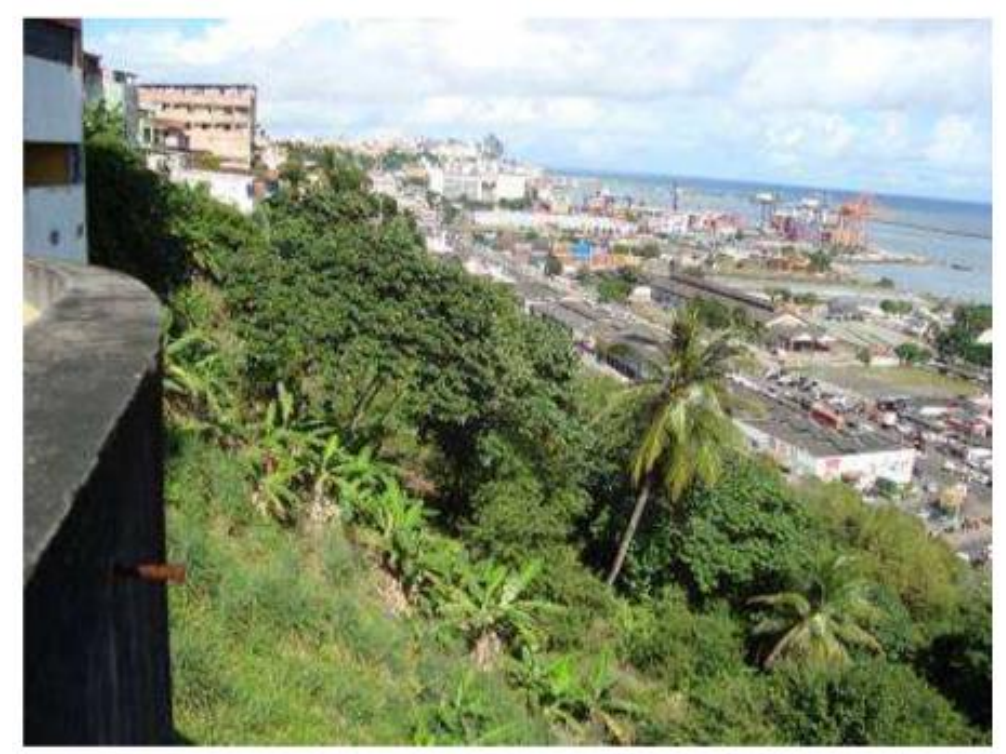

Figura 3.11 - Vegetação presente no talude, com caules inclinados devido à alta declividade do terreno (Correia et al., 2006)

\section{5 \\ Ocupação e Histórico}

A área de estudo é predominantemente residencial. O local é ocupado, além das casas antigas no topo, pela comunidade da Chácara do Santo Antônio, onde, segundo relatório da Geoeng (2014), estão alocadas mais de 100 famílias.

Durante a ocupação da cidade, na época da sua fundação (século XVI), as áreas de encosta da Falha de Salvador foram gradativamente ocupadas devido à sua importância estratégica e defensiva, ao proporcionar uma observação permanente da Baía de Todos os Santos, que precisava ser defendida do ataque de invasores (Elbachá, 1992).

Com o processo de crescimento da cidade, os entornos da região foram sendo ocupados desordenadamente, havendo retirada de parte da vegetação, depósito de lixo, esgoto e águas servidas no talude (atualmente, nem todas as casas contam com sistema de esgotamento do estado, e parte das instalações existentes estão danificadas), além da execução de aterros e cortes sem controle para a instalação de residências.

Somando as práticas inadequadas de uso e ocupação do solo, como exemplifica a Figura 3.12, com os altos índices pluviométricos dos períodos mais chuvosos, ocorreram os primeiros deslizamentos na região, ainda no século $\mathrm{XVI}$, registrados em textos de emissários da coroa portuguesa. A Tabela 3.1 lista os principais eventos ocorridos na área de estudo e entornos, com os descritos neste trabalho destacados em vermelho. 
Tabela 3.1 - Principais deslizamentos registrados na área de estudo e entornos desde o início da ocupação de Salvador (Dias, 2014; Silva, 2006; Jesus, 2008)

\begin{tabular}{l|c|l}
\hline \multicolumn{1}{c|}{ LOCAL } & ANO & \multicolumn{1}{c}{ DANOS } \\
\hline Conceição da Praia & 1631 & Perdas humanas e materiais \\
\hline $\begin{array}{l}\text { Ladeiras da Preguiça e da Con- } \\
\text { ceição }\end{array}$ & $\begin{array}{c}1714,1716 \\
\text { e } 1721\end{array}$ & Perdas materiais \\
\hline Castelo de São Bento & 1732 & Perdas humanas e materiais \\
\hline $\begin{array}{l}\text { Ladeira da Montanha e Encosta } \\
\text { do Pilar }\end{array}$ & 1748 & Perdas materiais \\
\hline Catedral da Sé & 1754 & Perdas materiais \\
\hline $\begin{array}{l}\text { Pilar, Santo Antônio Além do } \\
\text { Carmo e Lapinha }\end{array}$ & 1813 & Perdas materiais \\
\hline Túnel Américo Simas & 1971 & Perdas materiais \\
\hline Ladeira da Conceição & 1978 & Perdas humanas e materiais \\
\hline Liberdade & 1990 & Perdas humanas e materiais \\
\hline Santo Antônio Além do Carmo & 2011 & Perdas materiais \\
\hline
\end{tabular}
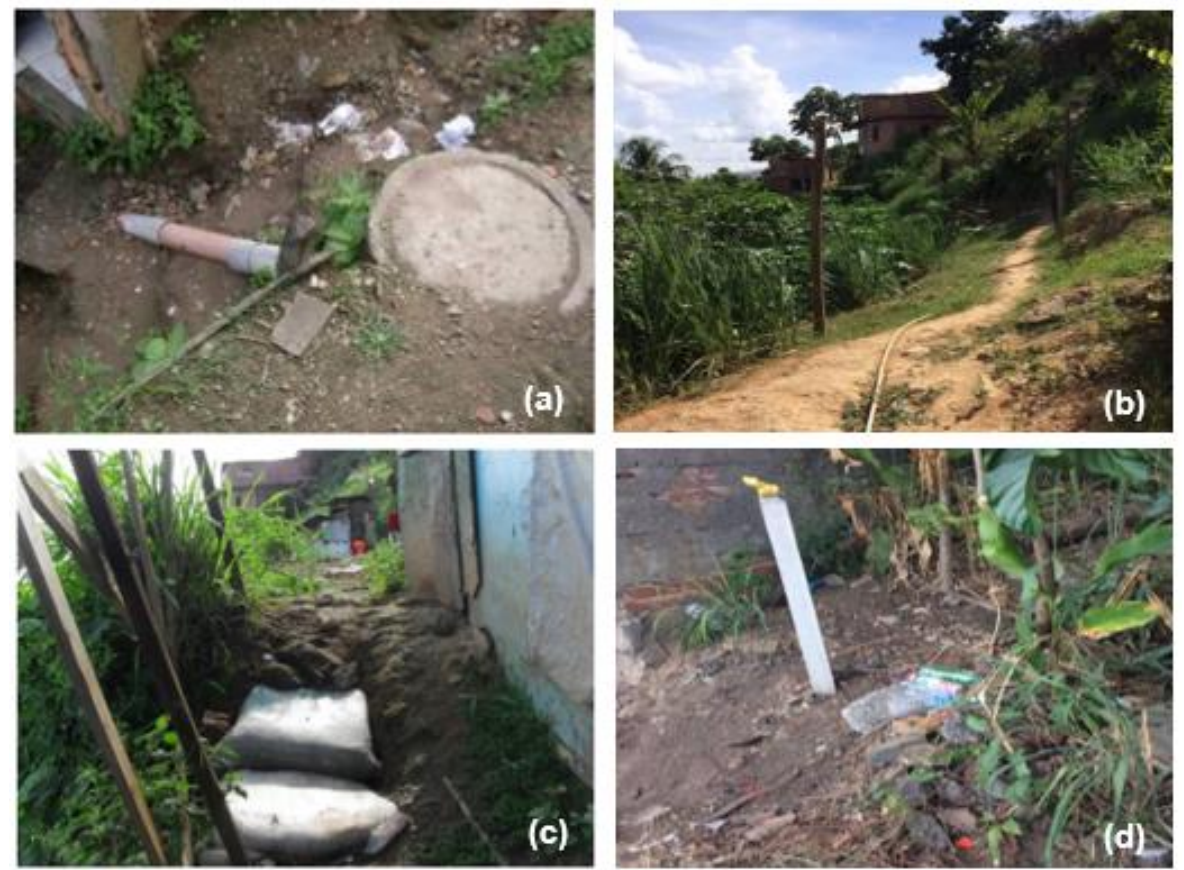

Figura 3.12 - Ação humana na encosta: (a) Sistema de esgotamento precário (Martins et al., 2012); (b) vegetação removida para passagem de moradores; (c) escada de sacaria para acesso (Geoeng, 2014) e (d) Deposição de lixo.

O deslizamento do Túnel Américo Simas, localizado às beiras do talude aqui estudado, ocorreu após uma precipitação acumulada de 500 mm em 3 dias, no mês de abril. Silva (2006) descreveu o evento, no qual a superfície do deslizamento se mostrou circular, passando pelo contato entre a rocha alterada e o solo 
argilo-arenoso caulinizado. É possível, segundo o autor, afirmar que a direção do escorregamento é a mesma do plano de fratura dominante no local.

O limite inferior da superfície se deu pela cortina atirantada existente nos arredores do local da ruptura, acima da cota $30 \mathrm{~m}$. O referido autor atribuiu às causas do deslizamento, além da precipitação acima da média, as condições geológicas, a alta declividade da encosta, as propriedades do material e condições de drenagem. Como consequência, diversas residências foram perdidas e o túnel foi interditado temporariamente.

O caso de 2011, no Santo Antônio Além do Carmo, se assemelha ao de 1971, tendo também ocorrido após chuvas intensas, conforme já relatado. O deslizamento teve como resultado 103 casas condenadas e 2 desabadas, conforme o Plano de Ação da Defesa Civil de Salvador (CODESAL). O evento constou em diversos deslizamentos ao longo da extensão do talude (Figura 3.13), sendo o principal o objeto de estudo deste trabalho (Figuras 3.14 e 3.15).

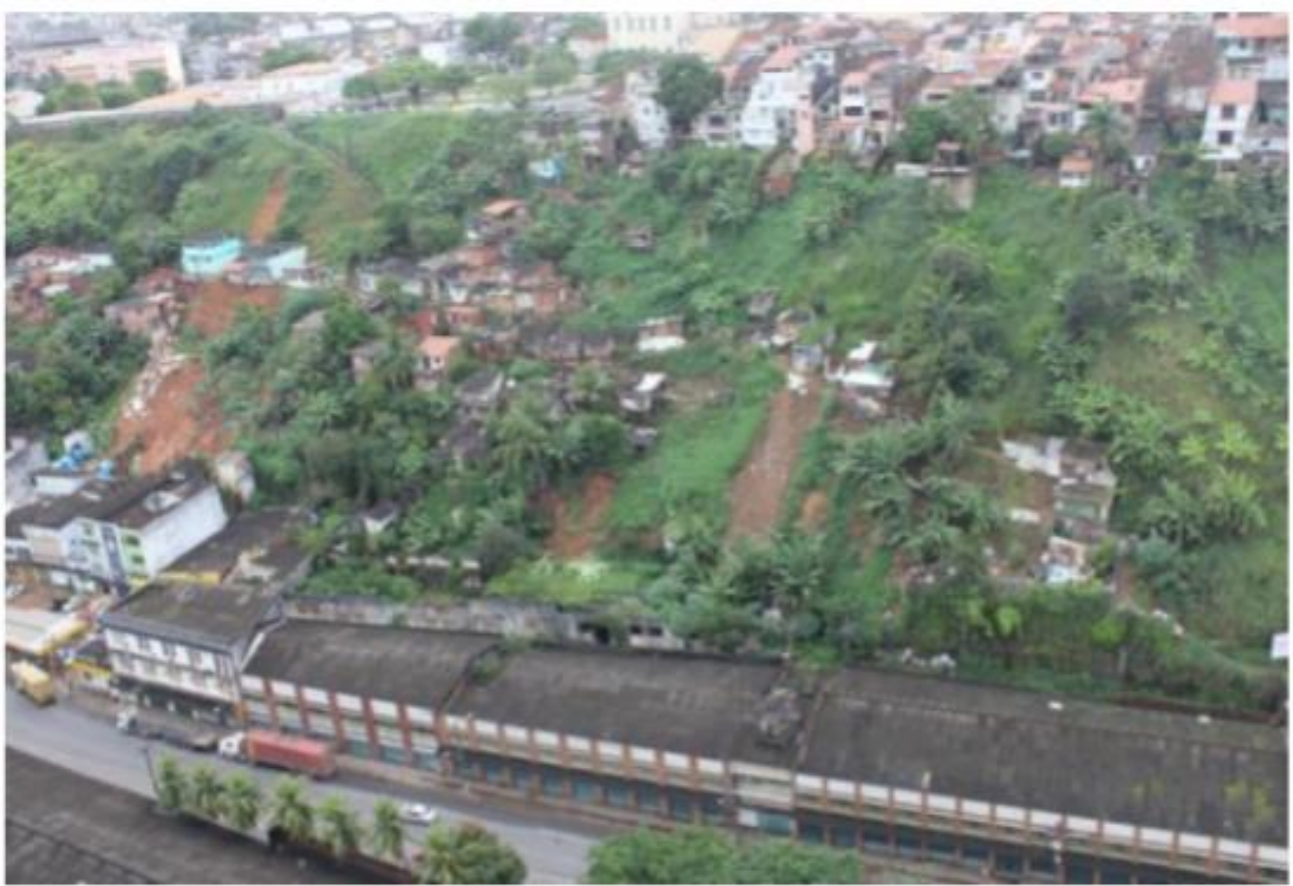

Figura 3.13 - Vista dos deslizamentos ocorridos no talude (Campos, 2011) 


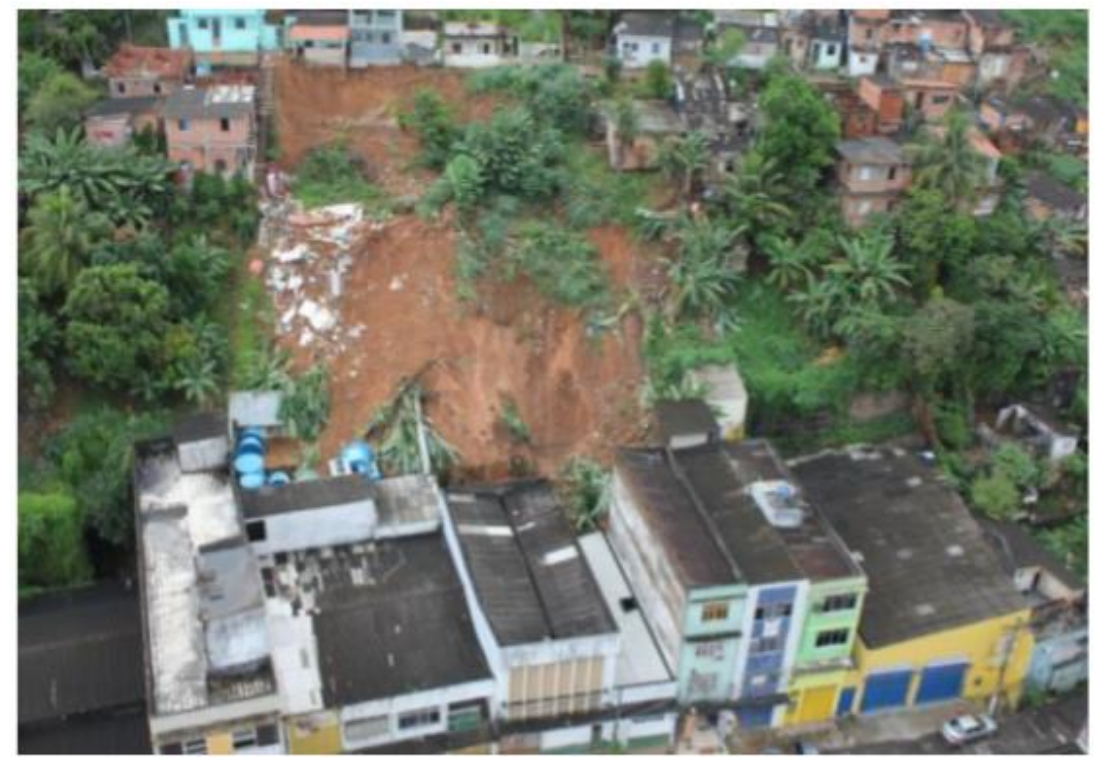

Figura 3.14 - Vista do maior deslizamento (Campos, 2011)

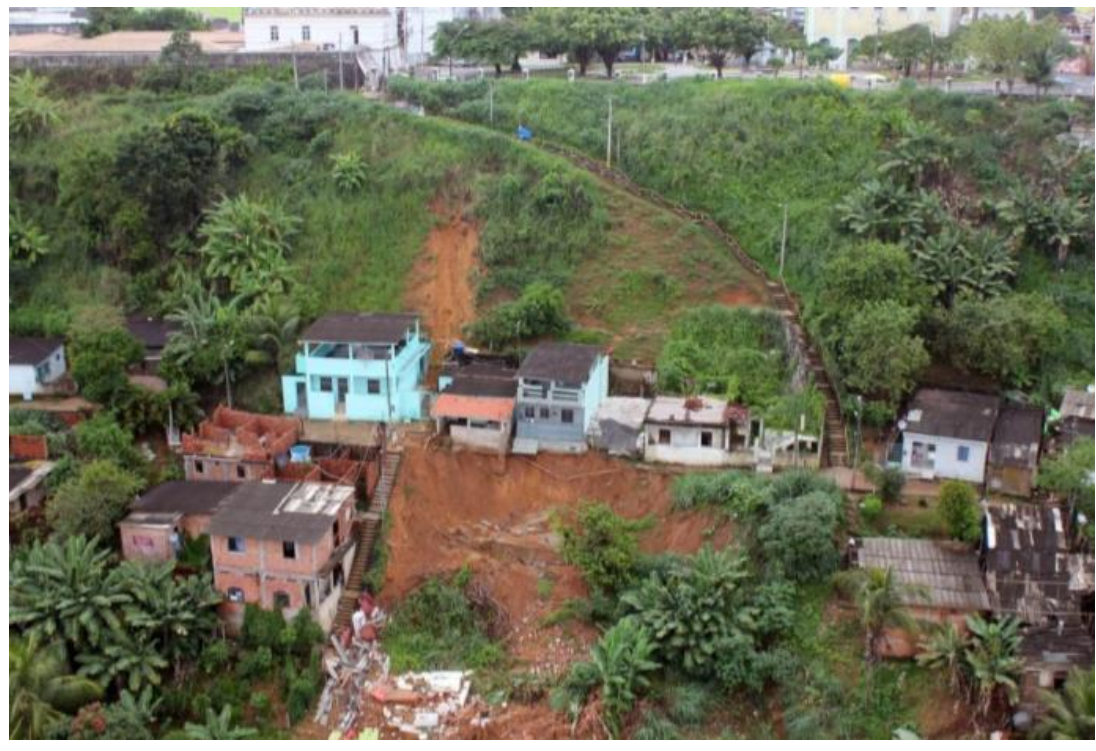

Figura 3.15- Detalhe do maior deslizamento (CODESAL, 2011)

Em visita ao local na época da ruptura, foram indentificadas fissuras no terreno e nas residências, que evoluíram com tempo, conforme ilustram as figuras 3.16 e 3.17 , constatando a contínua movimentação do maciço. O material deslizado atingiu diversas edificações instaladas no pé do talude, espalhando-se até a rua. 
As fotos da ruptura e observações de campo levam ao entendimento de que a superfície de ruptura tende a ser circular, de pequena profundidade, tendo mobilizado apenas a camada superficial, o que será verificado neste trabalho. Não há registros de sondagens ou coleta de amostras na época, sendo desconhecidos o nível d'água e a umidade do solo na ruptura.
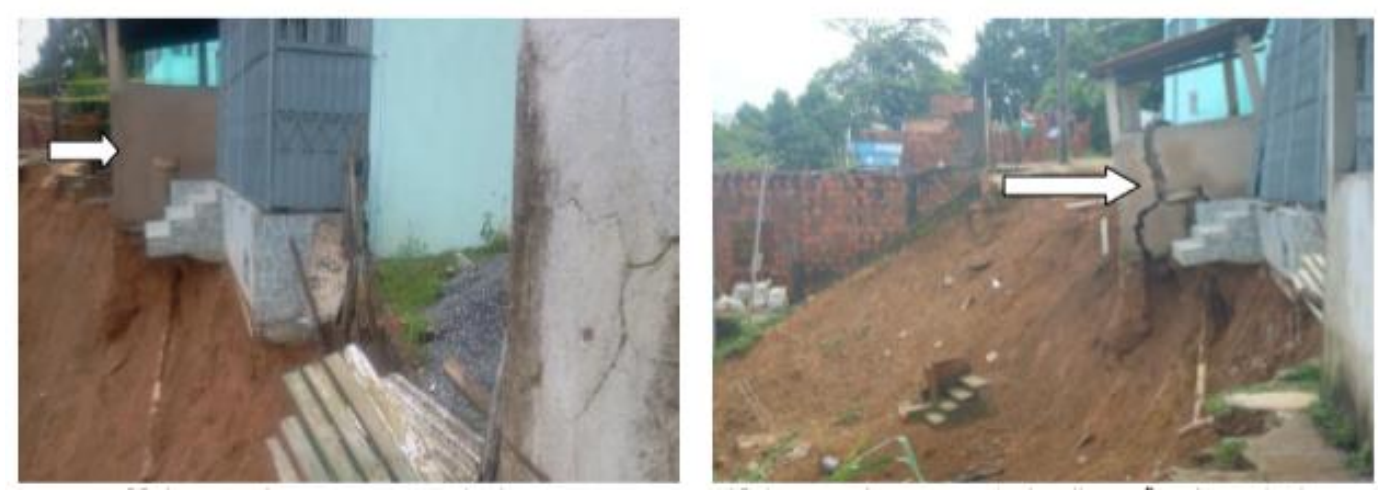

Figura 3.16 - Evolução das fissuras em casa do dia 9 para o dia 12/11 (CODESAL, 2011)
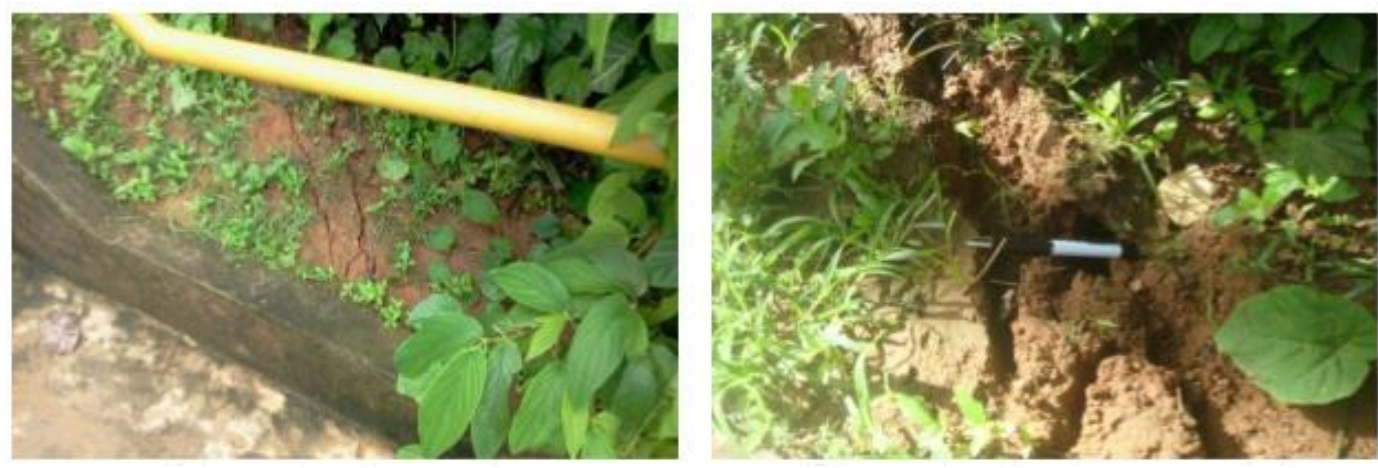

Figura 3.17 - Evolução das trincas no solo do dia 12 para o dia 17/11 (CODESAL, 2011)

\section{6} Investigação do subsolo

Para este trabalho, foram utilizados perfis de três campanhas de sondagem, realizadas em 2014, 2016 e 2017. Os principais perfis utilizados neste trabalho estão apresentados no anexo I e a planta de locação dos furos no anexo II. Para a campanha de 2017, foi possível ainda a obtenção do teor de umidade e densidade real dos grãos para cada metro, apresentados no anexo III.

O solo foi identificado como camadas de silte arenoso intercaladas com silte argiloso com areia. O SPT varia, no geral, entre 5 e 20 golpes, podendo ser vistos valores na faixa de 35 .

A camada superficial foi identificada na maioria dos perfis como provável aterro (vale ressaltar que grande parte dos furos foram realizados nos patamares 
onde ficam localizadas as casas, provavelmente pela facilidade de acesso), tendo sido encontrado lixo e entulho e, em alguns locais, material orgânico.

Obeserva-se nos perfis, após o aterro, a presença de material com pedregulho, seguido por um material composto por solo de alteração de rocha.

Para todas as sondagens, verificou-se a ausência de nível d'água no solo, estando este então localizado no material rochoso, conforme previsto no PDE (PMS, 2004). Como não foram realizadas sondagens rotativas, não se tem conhecimento da cota do NA. Observa-se, porém, que as campanhas foram realizadas no período de seca (janeiro a março) quando o NA provavelmente atinge sua menor cota.

\section{7 \\ Amostragem}

Foram coletadas amostras indeformadas e amolgadas de diferentes pontos da região, afim de se comparar seus parâmetros. Os pontos de coleta (Figura 3.18) foram escolhidos levando em consideração a acessibilidade e segurança. As Figuras 3.19 e 3.20 exemplificam a coleta de blocos no campo e o poço aberto para as amostras em profundidade.

Os blocos indeformados, com dimensões de aproximadamente $30 \times 30 \times 30 \mathrm{~cm}$, foram envoltos com papel alumínio, tecido e parafina, para conservação da umidade natural. Para o transporte, foram confeccionadas caixas de madeirite, tomando-se os devidos cuidados para que os blocos estivessem protegidos, como mostra a Figura 3.21.

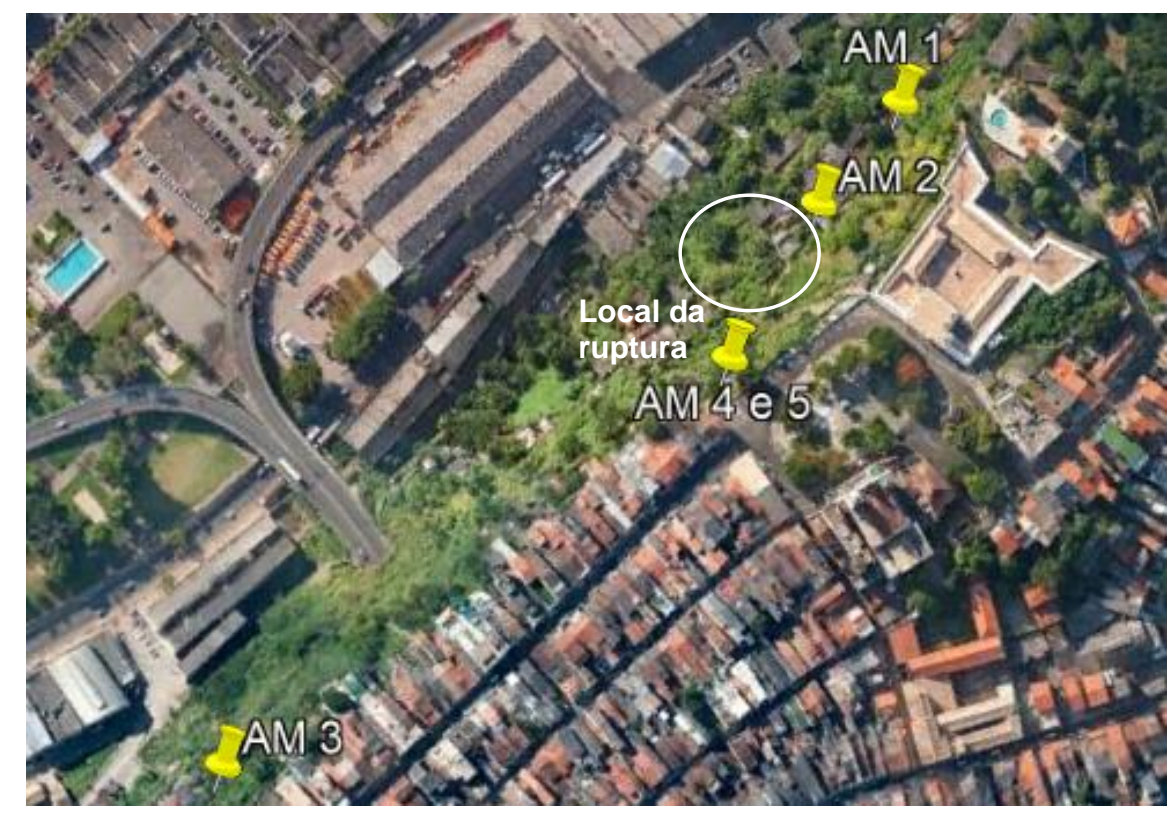

Figura 3.18 - Localização dos blocos coletados 


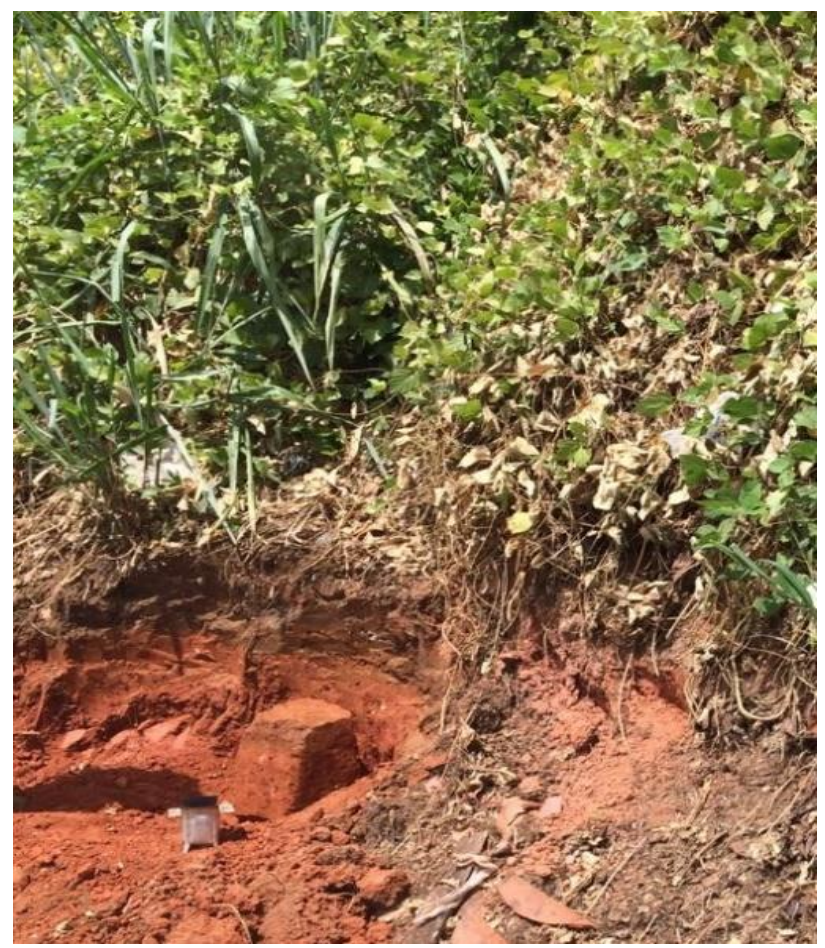

Figura 3.19 - Coleta de bloco no campo (AM 2)

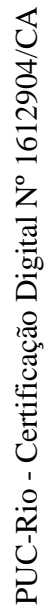

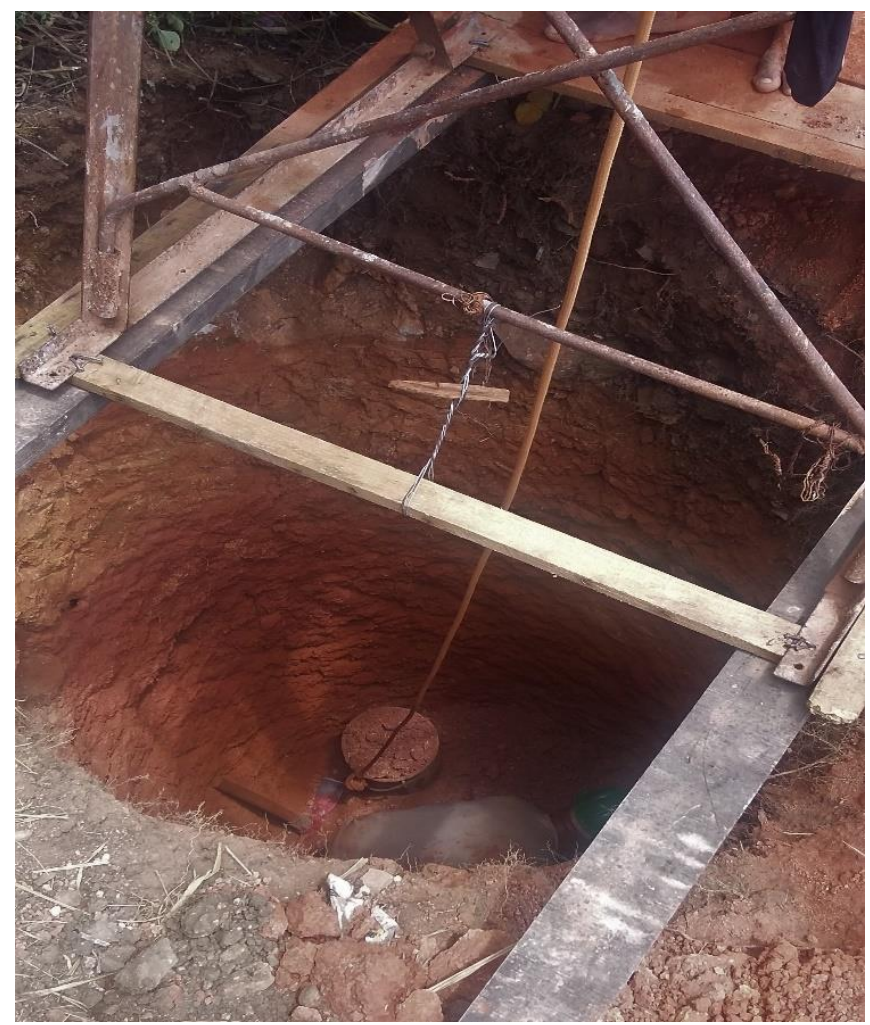

Figura 3.20 - Poço para coleta de amostras em profundidade (AM 4 e 5) 


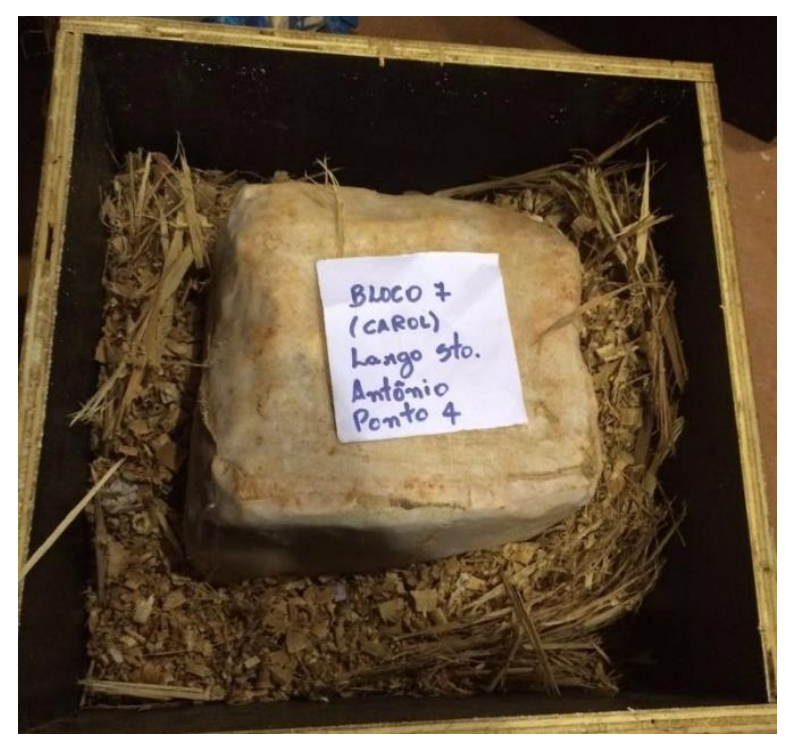

Figura 3.21 - Bloco na caixa para transporte

A Tabela 3.2 reune as principais informações das amostras coletadas neste trabalho. Estas apresentaram características próximas visualmente e ao tato, com apenas o solo da amostra 5 destacando-se dos demais, por apresentar material mais frágil à manipulação e coloração mais clara, além do maior teor de pedreguIho. Para as outras amostras, de cor avermelhada ou marrom mais escuro, percebe-se a presença de areia pelo tato.

Todas as amostras apresentaram plasticidade na presença de água, com destaque para a amostra 5 , na qual observou-se certa expansão quando saturada e contração quando seca.

Tabela 3.2 - Dados das amostras coletadas

\begin{tabular}{c|c|c|c|c|c|c}
\hline Amostra & $\begin{array}{c}\text { Data de } \\
\text { coleta }\end{array}$ & $\begin{array}{c}\text { Coordenadas } \\
(\mathbf{U T M})\end{array}$ & $\begin{array}{c}\text { Cota } \\
(\mathbf{m})\end{array}$ & $\begin{array}{c}\text { Prof. } \\
(\mathbf{m})\end{array}$ & Coloração & $\begin{array}{c}\boldsymbol{w}_{\text {campo }} \\
(\%)\end{array}$ \\
\hline AM 1 & $08 / 03 / 2017$ & $\begin{array}{c}553826 \mathrm{E} \\
8567001 \mathrm{~S}\end{array}$ & 39,0 & 0,5 & Marrom & 20,5 \\
\hline AM 2 & $08 / 03 / 2017$ & $\begin{array}{c}553802 \mathrm{E} \\
8566946 \mathrm{~S}\end{array}$ & 36,5 & 0,5 & Avermelhada & 21,0 \\
\hline AM 3 & $09 / 03 / 2017$ & $\begin{array}{c}553604 \mathrm{E} \\
8566625 \mathrm{~S}\end{array}$ & 40,0 & 0,5 & Avermelhada & 23,3 \\
\hline AM 4 & $28 / 03 / 2017$ & $553781 \mathrm{E}$ & 62,0 & 2,0 & Marrom & 22,1 \\
\cline { 1 - 4 } AM 5 & $29 / 03 / 2017$ & \begin{tabular}{c}
$8566867 \mathrm{~S}$ \\
\cline { 5 - 7 }
\end{tabular} & 60,0 & 4,0 & $\begin{array}{c}\text { Marrom, com } \\
\text { alguns pontos } \\
\text { amarelados }\end{array}$ & 24,9 \\
\hline
\end{tabular}




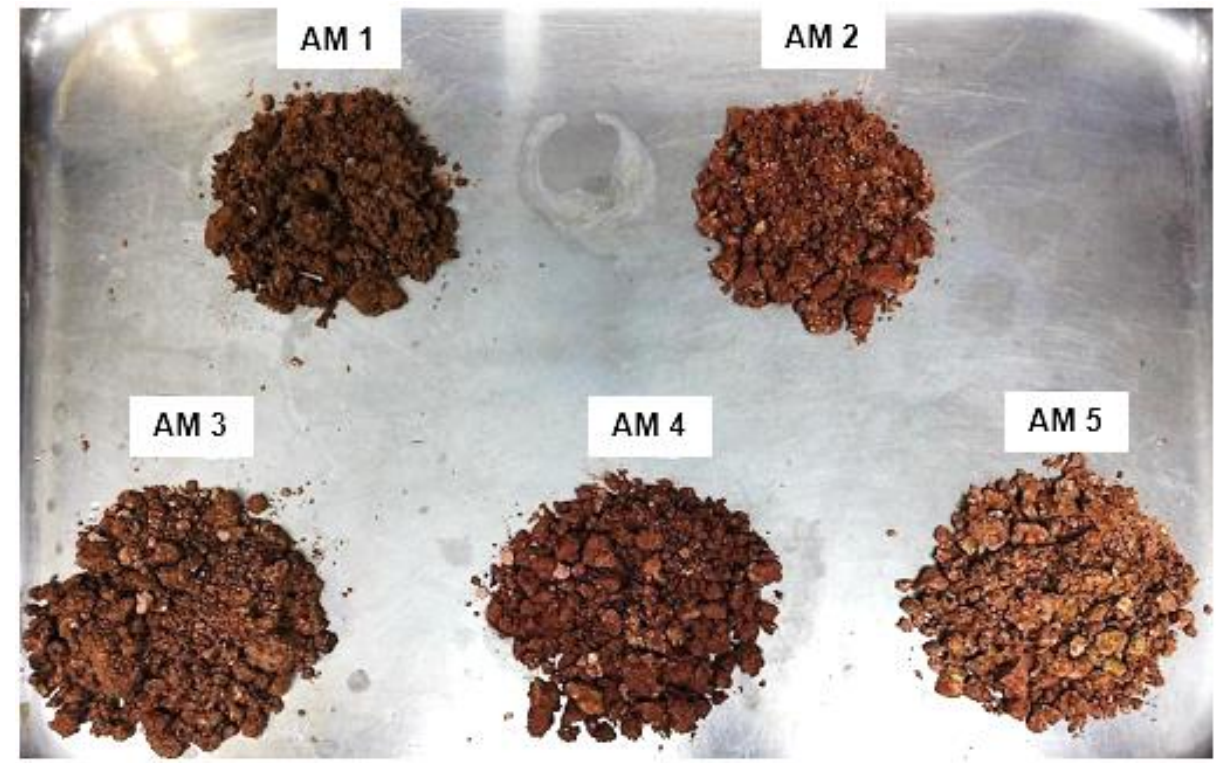

Figura 3.22 - Visual das amostras coletadas 


\section{4}

\section{Equipamentos, técnicas e programa experimental}

Para a caracterização e obtenção dos parâmetros de resistência e permeabilidade do material coletado, foi estabelecido um programa de ensaios, conforme a Tabela 4.1.

A primeira etapa englobou os ensaios de caracterização física, química e mineralógica, além das curvas características, complementadas pela porosimetria de mercúrio.

Na segunda etapa, foram realizados os ensaios para obtenção dos parâmetros de resistência, por meio de ensaios de cisalhamento direto nas amostras indeformadas. Foram realizados ensaios nas condições submersa e seca. Os ensaios na condição seca, utilizados na determinação das envoltórias não saturadas através da equação de Vilar (2006), foram realizados apenas nos blocos mais próximos ao local da ruptura.

Para a determinação da permeabilidade saturada, foram realizados ensaios de permeabilidade de laboratório (permeâmetro de carga constante com parede flexível) e campo (permeâmetro de Guelph). 
Tabela 4.1 - Programa experimental

\begin{tabular}{|c|c|c|c|c|c|}
\hline \multirow{2}{*}{ ENSAIO } & \multicolumn{5}{|c|}{ AMOSTRA } \\
\hline & AM 1 & AM 2 & AM 3 & AM 4 & AM 5 \\
\hline \multicolumn{6}{|l|}{ CARACTERIZAÇÃO } \\
\hline \multicolumn{6}{|l|}{ Física } \\
\hline Granulometria & $X$ & $X$ & $X$ & $X$ & $X$ \\
\hline Limites de consistência & $X$ & $x$ & $X$ & $X$ & $X$ \\
\hline Densidade relativa dos grãos & $X$ & $X$ & $X$ & $X$ & $X$ \\
\hline \multicolumn{6}{|l|}{ Química } \\
\hline Fluorescência de raio-x & $\mathrm{X}$ & $\mathrm{X}$ & $\mathrm{X}$ & $\mathrm{X}$ & $\mathrm{X}$ \\
\hline \multicolumn{6}{|l|}{ Mineralógica } \\
\hline Difração de raio-x (método do pó) & $\mathrm{X}$ & $x$ & $x$ & $x$ & $\mathrm{X}$ \\
\hline Difração de raio-x (lâmina orientada) & - & - & - & - & $X$ \\
\hline CURVA CARACTERÍSTICA & $X$ & $X$ & $x$ & $X$ & $X$ \\
\hline POROSIMETRIA DE MERCÚRIO & $X$ & $X$ & $X$ & $X$ & $\mathrm{X}$ \\
\hline \multicolumn{6}{|l|}{ PERMEABILIDADE SATURADA } \\
\hline Permeâmetro de Guelph & - & $X$ & $X$ & $X$ & $X$ \\
\hline Permeâmetro carga constante & $\mathrm{X}$ & $X$ & $\mathrm{X}$ & $\mathrm{X}$ & $X$ \\
\hline \multicolumn{6}{|l|}{ RESISTÊNCIA } \\
\hline Cisalhamento direto - submerso & $X$ & $X$ & $X$ & $X$ & $X$ \\
\hline Cisalhamento direto - seco & - & $\mathrm{X}$ & - & $\mathrm{X}$ & $\mathrm{X}$ \\
\hline
\end{tabular}

\section{1}

\section{Caracterização das amostras}

\subsection{1}

\section{Caracterização física}

Para determinação das características físicas das amostras, foram realizados ensaios de granulometria, limites de Atterberg e densidade relativa dos grãos, no Laboratório de Geotecnia da Universidade Federal da Bahia. Os procedimentos foram realizados com base nas seguintes normas:

- $\quad$ NBR 7181/84 - Análise granulométrica;

- NBR 6459/84 - Limite de Liquidez;

- NBR 7180/84 - Limite de Plasticidade;

- NBR 6508/84 - Determinação da massa específica. 
Com base nos resultados, foi possível a classificação das amostras de acordo com sistema unificado (SUCS). Obteve-se também os índices físicos das amostras através da determinação da umidade e correlações básicas.

\subsection{2}

\section{Caracterização química}

A determinação da porcentagem dos principais elementos químicos que compõem o solo e seu grau de intemperismo deram-se através ensaios de fluorescência de raio-x no Laboratório de Espectometria e Fluorescência de Raios-X do CETEM. Foi realizada uma análise semiquantitativa, em espectrômetro de fluorescência WDS-2, modelo AXIOS, usando como aglomerante ácido bórico na proporção de 1:0,3 da amostra seca à $100^{\circ} \mathrm{C}$.

A perda por calcinação das amostras foi feita em equipamento Leco TGA701. O ensaio era finalizado após 3 pesagens sequenciais idênticas.

\subsection{3 Caracterização mineralógica}

A caracterização mineralógica foi realizada primeiramente para todas as amostras através de difração de raio-x pelo método do pó. Para a AM 5, realizouse esta, ainda, pelo método da lâmina orientada, afim de detectar a presença de algum argilomineral expansivo nas frações areia ou silte do solo, por conta do grau de atividade médio encontrado na caracterização física e comportamento na presença de água.

Para o método do pó, as amostras integrais foram previamente destorroadas. No caso da lâmina orientada, primeiramente lavou-se o solo na peneira \# 200 para separar as frações grossa e fina; a separação do silte e da argila foi obtida pela sedimentação do material. As lâminas foram então confeccionadas, para as três frações separadas, e para o solo, usando-se o método do gotejamento.

Os ensaios foram realizados no laboratório do Departamento de Ciência dos Materiais e Metalurgia (DCMM) da PUC-Rio, com o uso do difratômetro Siemens D5000. 


\section{2 \\ Curva característica de retenção de água}

Conforme já mencionado, as curvas características do material estudado foram obtidas pelos métodos do papel filtro e potenciômetro de ponto de orvalho. Para o primeiro, seguiu-se o procedimento descrito por Marinho (1994), enquanto para o segundo, foi usado o manual do fabricante (Decagon Devices, 2010).

Foram moldados corpos de prova pela cravação nos blocos indeformados de anéis metálicos de, em média, $47 \mathrm{~mm}$ de diâmetro e $20 \mathrm{~mm}$ de altura. Cada anel foi medido e pesado individualmente. Na moldagem dos corpos de prova, retirouse material do topo e da base para determinação da umidade. Com os índices físicos do material, foi possível calcular a quantidade de água a ser adicionada ou removida para se chegar ao teor de umidade desejado.

Para cada amostra, foram inicialmente confeccionados 10 corpos de prova, sendo 4 submetidos a um processo de secagem ao ar, 5 a um processo de umedecimento, pelo gotejamento de água, e 1 permaneceu em sua umidade natural. Não foi objetivo deste trabalho se obter a histerese das curvas, tendo os ajustes sido feitos como unimodal ou bimodal em função dos resultados da porosimetria de mercúrio.

Com os corpos de prova na umidade desejada, estes foram envoltos em papel filme e papel alumínio e inseridos em uma caixa de isopor por um período de $24 \mathrm{~h}$, para que ocorresse a equalização da umidade. Após este procedimento, eram colocados papéis filtro em contato direto no topo e na base do material, que foram novamente embrulhados com papel filme e papel alumínio, e ainda fechados em sacos (Figura 4.1), e colocados na caixa de isopor por 7 dias. A manipulação do papel filtro foi realizada sempre com o uso de pinça e luvas.
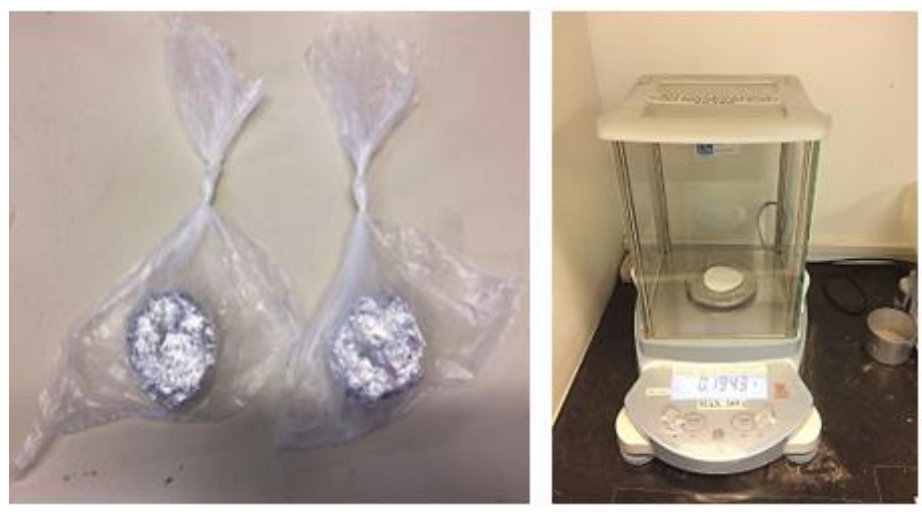

Figura 4.1 - Embrulhos para impedir a perda de umidade nos corpos de prova e pesagem do papel filtro em balança de precisão de quatro casas decimais 
Após este período, os embrulhos foram abertos, individualmente, ao lado de uma balança de $0,0001 \mathrm{~g}$ de precisão, onde os papéis filtro foram pesados em intervalos de tempo de 10 s nos dois primeiros minutos e de 15 s no último minuto. Então, os papéis filtro foram colocados na estufa a $110^{\circ} \mathrm{C}$ por um período de $2 \mathrm{~h}$, pesando-os novamente, no mesmo procedimento anterior.

A massa do papel filtro no tempo zero foi obtida através da extrapolação da curva de variação da massa do papel filtro $x$ tempo. Com as massas úmida e seca do papel filtro, é possível se determinar sua umidade e, através da curva de calibração de Chandler et al. (1992), sua sucção. Os corpos de prova também eram pesados e colocados na estufa por $24 \mathrm{~h}$ para determinação de sua umidade final.

Para os intervalos que não foram comtemplados após a primeira execução dos ensaios, foram realizados ensaios adicionais, com os pontos para sucções a partir de $100 \mathrm{kPa}$ realizados no potenciômetro de ponto de orvalho. A utilização do segundo método se justificou na maior simplicidade e rapidez de execução.

\section{3 Porosimetria de mercúrio}

O tamanho e distribuição dos poros, que pode ocorrer de forma unimodal ou bimodal, pode ser detectada pela porosimetria de mercúirio. O procedimento de ensaios consiste em injetar mercúrio sob pressão na amostra de solo seca, aplicando-se então vácuo para que o mercúrio penetre nos poros do solo sem que haja interferência da água e ar, medindo-se o volume de mercúrio penetrado em cada estágio (Reis, 2004, apud Delcourt, 2015)

Os ensaios foram realizados no Laboratório de Apoio à Física e à Química da Universidade de São Paulo, unidade São Carlos.

\section{4}

\section{Permeabilidade saturada}

\subsection{1}

\section{Permeâmetro de Guelph}

Os ensaios foram realizados com o permeâmetro da UFBA, da marca Soilmoisture. O solo foi perfurado com trado e, através de um prolongamento feito de tubos de PVC, foi possível a realização de ensaios em furos de até $6 \mathrm{~m}$ de profundidade. 
O equipamento (Figura 4.2) é composto por um vaso de Mariotte, que tem a função de manter constante a carga d'água no meio poroso, apoiado em um tripé, que permite a adaptação à terrenos irregulares.

O procedimento de ensaio consistiu em permitir o fluxo d'água, gerando um bulbo de saturação, com a taxa de infiltração no solo tornando-se constante após um determinado tempo. Nos materiais cuja infiltração era rápida, o ensaio foi realizado utilizando-se o tubo externo, e para infiltrações mais demoradas (menor permeabilidade), o tubo interno.

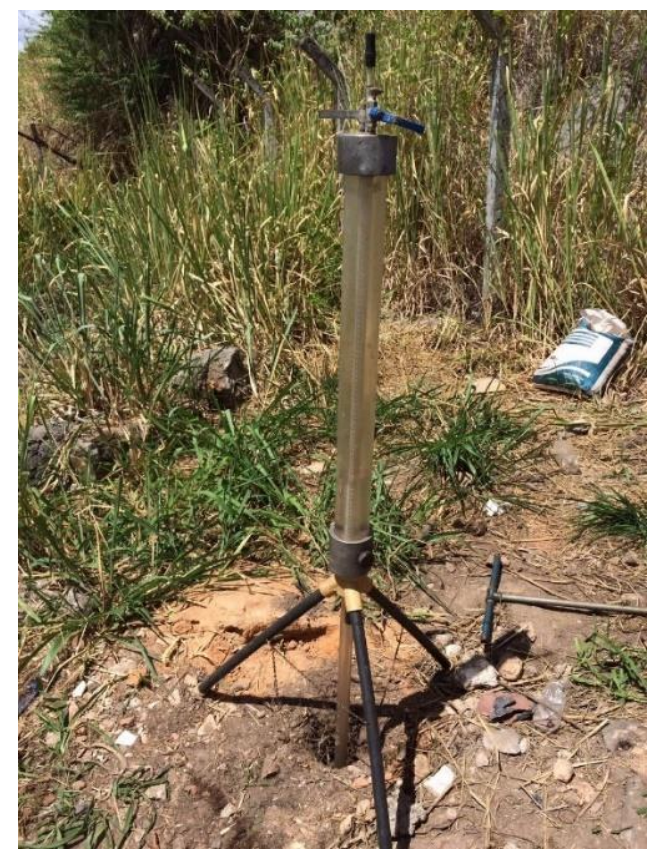

Figura 4.2 - Permeâmetro de Guelph utilizado nos ensaios de campo

\subsection{2}

\section{Permeâmetro de carga constante com parede flexível}

Estes ensaios foram realizados em uma célula triaxial, no LGMA da PUCRio, como ilustra a Figura 4.3, em amostras de aproximadamente $38 \mathrm{~mm}$ de diâmetro e 79,5mm de altura. Na primeira etapa do ensaio, o corpo de prova era saturado, percolando-se água neste por uma diferença de carga de entre o topo e a base até que se atingisse um parâmetro $B$ de pelo menos 0,95.

Com o material saturado, media-se o volume de água percolado por pelo menos um enchimento e esvaziamento do medidor de variação de volume acoplado ao equipamento, com o tempo necessário para tal. 


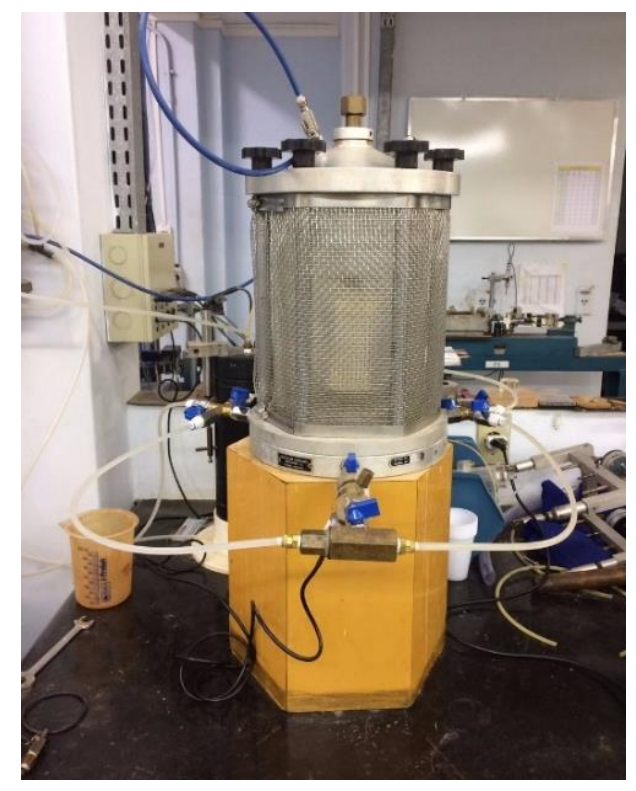

Figura 4.3 - Permeâmetro de parede flexível

\section{5}

\section{Ensaios de resistência}

Os ensaios de cisalhamento direto foram realizados no Laboratório de Geotecnia e Meio Ambiente da PUC-Rio, utilizando os equipamentos da marca Wykeham Farrance mostrados na Figura 4.4. Foram realizados ensaios para tensões normais de 50, 100 e $200 \mathrm{kPa}$, em corpos de prova de aproximadamente 100 $\mathrm{mm}$ de lado e $20 \mathrm{~mm}$ de altura, como o da Figura 4.5. Para garantir que os ensaios ocorreriam na condição drenada, foi adotada uma velocidade de cisalhamento de $0,0122 \mathrm{~mm} / \mathrm{min}$, aproximadamente 10 vezes menor que a calculada pelo método de Gibson e Henkel (1954).

Para os ensaios submersos, foi adicionada água destilada, deixando-se o corpo de prova adensar. Os corpos de prova para os ensaios secos foram deixados secar ao ar até que atingissem uma umidade menor ou igual à residual, de acordo com suas respectivas curvas características. 

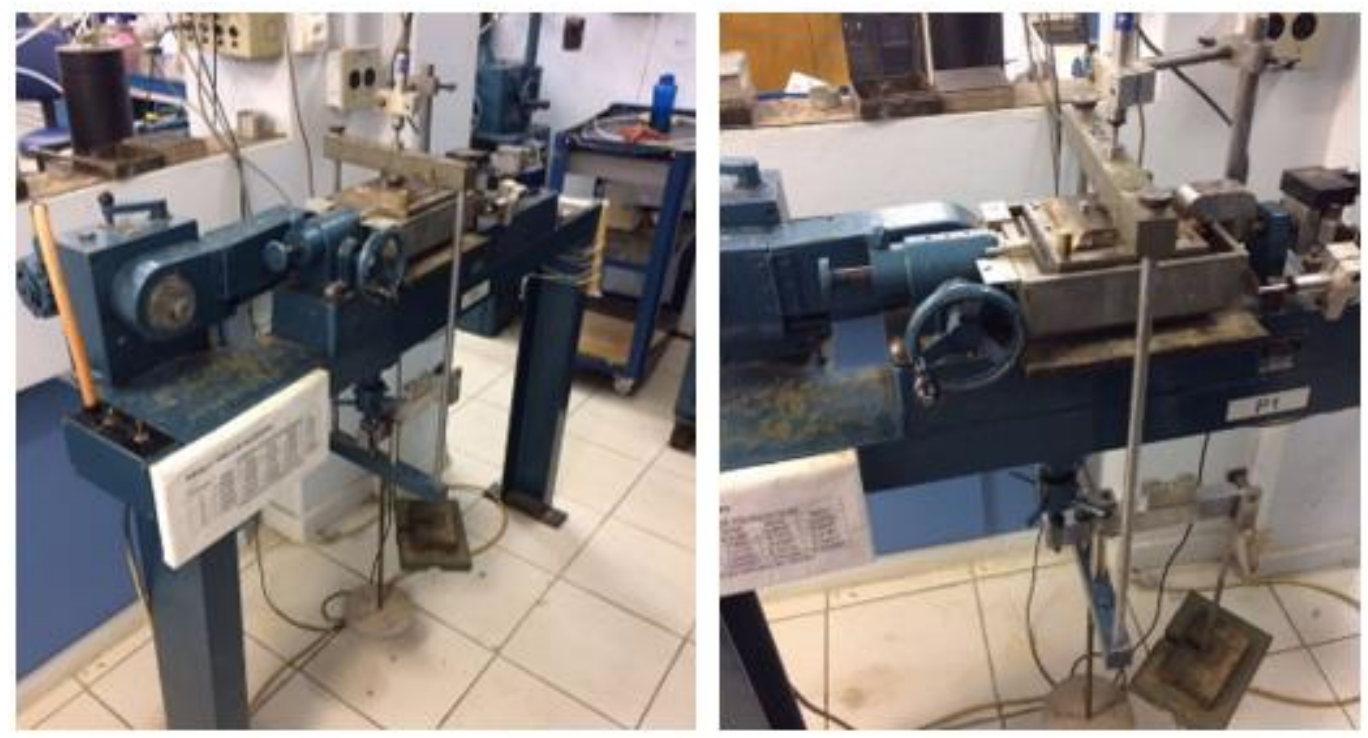

Figura 4.4 - Equipamento de cisalhamento direto da PUC-Rio

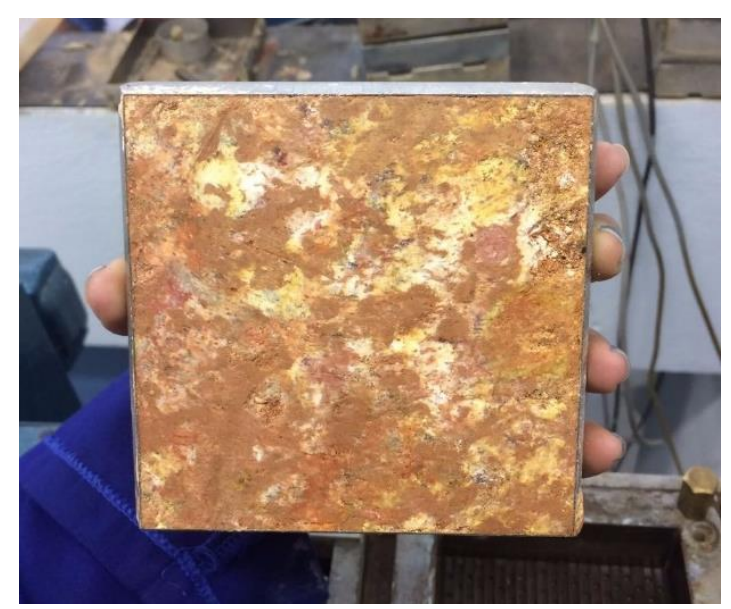

Figura 4.5 - Corpo de prova moldado para ensaio de cisalhamento direto

Para as curvas que não apresentaram pico, as tensões na ruptura foram determinadas pelo critério de De Campos e Delgado (1995), o qual considera que a ruptura ocorre quando a curva tensão x deformação atinge uma inclinação constante (Figura 4.6). As curvas que apresentaram pico tiveram seus pares de tensões na ruptura definido a partir do valor máximo de tensão cisalhante atingido no ensaio. 


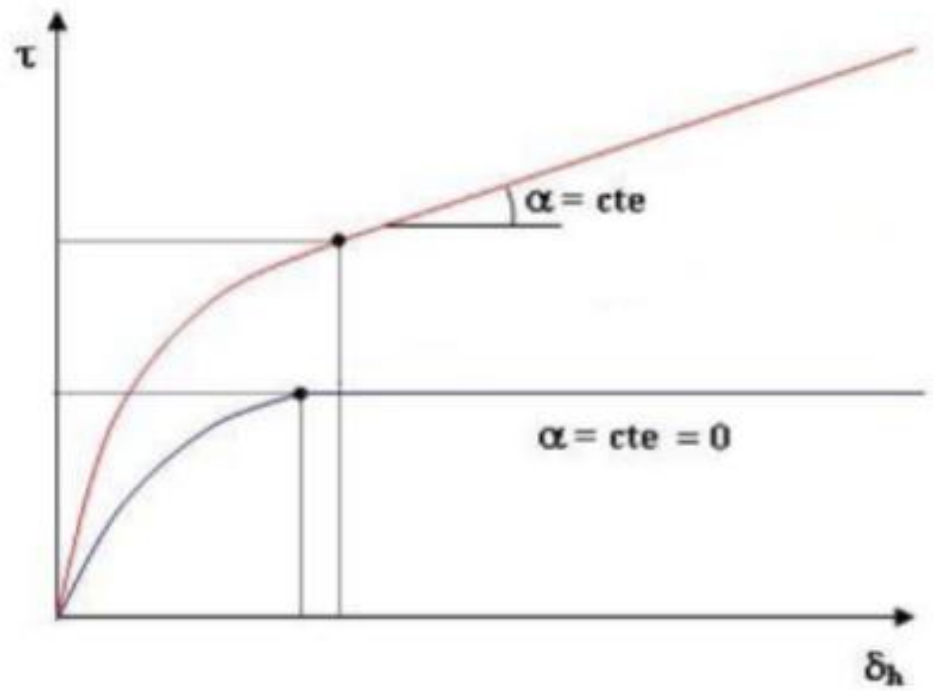

Figura 4.6 - Critério de definição dos pontos de ruptura (De campos e Delgado, 1995, apud Oliveira, 2013) 


\section{Ensaios de caracterização}

5.1

\section{Caracterização física}

\section{1 .1}

Índices físicos

Os índices físicos dos solos estudados foram calculados para anéis cravados nos blocos indeformados, chegando-se aos valores médios da Tabela 5.1:

Tabela 5.1 - Índices físicos médios das amostras

\begin{tabular}{c|c|c|c|c|c|c|c}
\hline Amostra & Gs & $\boldsymbol{\gamma}_{\text {nat }}\left(\mathbf{K N} / \mathbf{m}^{\mathbf{3}}\right)$ & $\boldsymbol{\gamma}_{\boldsymbol{d}}\left(\mathrm{KN} / \mathbf{m}^{\mathbf{3}}\right)$ & $\mathbf{e}$ & $\mathbf{n}$ & $\mathbf{w}(\%)$ & $\mathbf{S}(\%)$ \\
\hline AM 1 & 2,69 & 16,74 & 14,82 & 0,78 & 0,44 & 12,93 & 44,55 \\
\hline AM 2 & 2,78 & 16,25 & 13,38 & 1,04 & 0,51 & 21,45 & 57,34 \\
\hline AM 3 & 2,70 & 15,44 & 13,50 & 0,97 & 0,49 & 14,36 & 40,43 \\
\hline AM 4 & 2,76 & 17,77 & 14,23 & 0,91 & 0,47 & 24,90 & 75,94 \\
\hline AM 5 & 2,78 & 15,54 & 11,59 & 1,36 & 0,58 & 34,11 & 70,05 \\
\hline
\end{tabular}

\section{1 .2}

\section{Análise granulométrica}

Os resultados dos ensaios de granulometria realizados estão dispostos na Tabela 5.2 e Figura 5.1.

Tabela 5.2 - Distribuição granulométrica do material estudado (\%)

\begin{tabular}{|c|c|c|c|c|c|c|c|c|}
\hline \multirow{2}{*}{ Amostra } & \multirow{2}{*}{ Pedreg. } & \multicolumn{3}{|c|}{ Areia } & \multirow{2}{*}{$\%$ Grossos } & \multirow{2}{*}{ Silte } & \multirow{2}{*}{ Argila } & \multirow{2}{*}{$\%$ Finos } \\
\hline & & Grossa & Média & Fina & & & & \\
\hline AM 1 & 7 & 14 & 13 & 10 & 44 & 17 & 39 & 56 \\
\hline AM 2 & 8 & 10 & 8 & 9 & 35 & 25 & 40 & 65 \\
\hline AM 3 & 0 & 10 & 16 & 15 & 41 & 33 & 26 & 59 \\
\hline AM 4 & 0 & 7 & 14 & 11 & 32 & 25 & 43 & 68 \\
\hline AM 5 & 27 & 10 & 9 & 9 & 55 & 26 & 19 & 45 \\
\hline
\end{tabular}




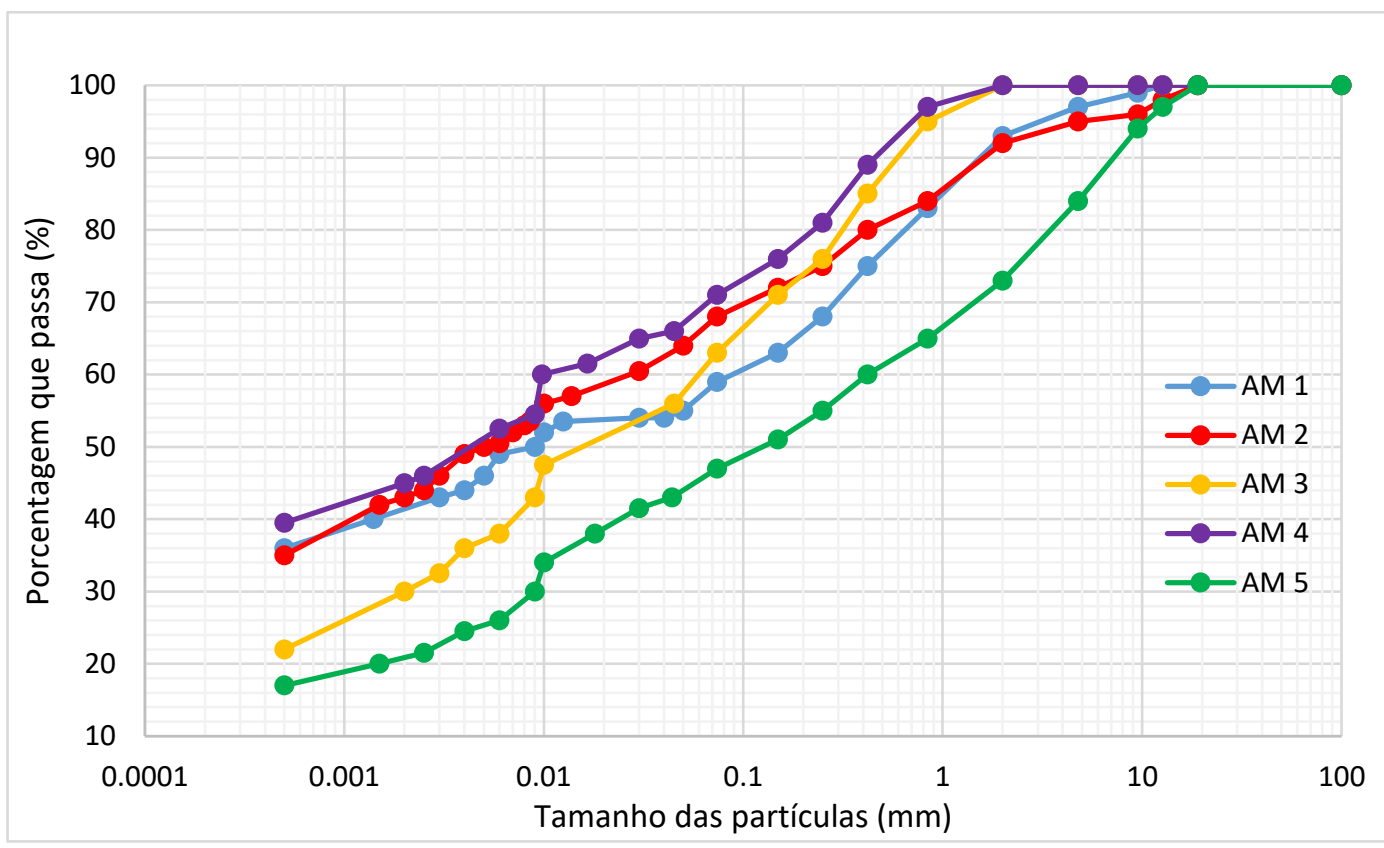

Figura 5.1 - Curvas granulométricas das amostras

Pelos teores das frações e curvas granulométricas, pode ser verificado que as amostras 1, 2 e 4 apresentam distribuições próximas, com as amostras 3 e 5 indicando distribuições próprias.

Observou-se que apenas o solo 5 apresenta uma proporção maior de material grosso com $55 \%$, predominando no restante das amostras o material fino, entre 56 e $68 \%$. Este material também se destaca pela maior porcentagem de pedregulho, de $27 \%$, e menor teor de argila (19\%), destoando dos outros solos.

Apesar do solo 3 também possuir maior teor de finos (59\%), este se diferencia das amostras 1, 2 e 4 pelo menor teor de argila, igual a $26 \%$, enquanto as outras apresentam valores próximos a $40 \%$.

\subsection{3}

\section{Limites de Consistência}

A Tabela 5.3 mostra os limites de consistência encontrados para as amostras, que indicam a mudança de estado da fração fina do solo. Calculou-se, ainda, o grau de atividade de Skempton $(A)$ para cada amostra, conforme a equação 5.1 :

$$
A=\frac{I P}{\%<0,02 \mathrm{~mm}}
$$


Tabela 5.3 - Limites de consistência e grau de atividade das amostras

\begin{tabular}{c|c|c|c|c}
\hline Amostra & LL (\%) & LP (\%) & IP (\%) & A \\
\hline AM 1 & 53 & 33 & 20 & 0,51 \\
\hline AM 2 & 57 & 31 & 26 & 0,65 \\
\hline AM 3 & 39 & 26 & 13 & 0,50 \\
\hline AM 4 & 52 & 33 & 19 & 0,44 \\
\hline AM 5 & 45 & 27 & 18 & 0,95 \\
\hline
\end{tabular}

Assim como na análise granulométrica, são observados três comportamentos nos limites, um para as amostras 1,2 e 4, com os maiores valores de limite de liquidez e plasticidade e IP entre $19 \%$ e $26 \%$; outro para a amostra 3 com os menores valores para os limites e o menor IP, de 13\%; e um terceiro para a amostra 5 , com $18 \%$ de IP. O maior limite de liquidez da amostra 2 rendeu à mesma 0 maior índice de plasticidade.

As amostras de 1 a 4 foram classificadas como de baixa atividade (menor que 0,75), enquanto o material da AM 5 apresentou um grau de atividade de 0,95, consideravelmente maior que as outras, classificando-se como de atividade média (entre 0,75 e 1,25). Esta pode ser atribuída à baixa porcentagem de argila deste material. Uma possível explicação pode ser vista mais adiante.

\section{1 .4}

\section{Classificação do solo}

Com os resultados da caracterização física, foi possível classificar o material de acordo com o Sistema Unificado (SUCS), conforme exposto na Tabela 5.4.

Tabela 5.4 - Classificação do material coletado de acordo com o SUCS

\begin{tabular}{c|c|c}
\hline Amostra & Simbologia & Descrição \\
\hline AM 1 & MH & Silte de alta plasticidade \\
\hline AM 2 & & Silte pouco plástico \\
\hline AM 3 & ML & Silte de alta plasticidade \\
\hline AM 4 & MH & Areia siltosa \\
\hline AM 5 & SM & \\
\hline
\end{tabular}

\section{2}

\section{Caracterização química}

As Tabelas 5.5 e 5.6 apresentam os resultados encontrados: 
Tabela 5.5 - Componentes químicos das amostras

\begin{tabular}{c|c|c|c|c|c|c|c|c|c|c}
\hline Amostra & $\mathbf{M g O}$ & $\mathbf{A l}_{2} \mathbf{O}_{\mathbf{3}}$ & $\mathbf{S i O}_{\mathbf{2}}$ & $\mathbf{P}_{\mathbf{2}} \mathbf{O}_{\mathbf{5}}$ & $\mathbf{S O}_{\mathbf{3}}$ & $\mathbf{K}_{\mathbf{2}} \mathbf{O}$ & $\mathbf{C a O}$ & $\mathbf{T i O}_{\mathbf{2}}$ & $\mathbf{F e}_{\mathbf{2}} \mathbf{O}_{\mathbf{3}}$ & $\mathbf{Z r O}_{\mathbf{2}}$ \\
\hline AM 1 & ND & 36,5 & 39,5 & 0,3 & $<0,1$ & $<0,1$ & $<0,1$ & 2 & 11,5 & $<0,1$ \\
\hline AM 2 & 0,15 & 36,4 & 38,1 & 0,52 & 0,17 & $<0,1$ & 0,11 & 2 & 10,7 & 0,13 \\
\hline AM 3 & 0,18 & 33,3 & 52,4 & 0,35 & $<0,1$ & 0,2 & 0,51 & 0,59 & 4,1 & $<0,1$ \\
\hline AM 4 & ND & 36,8 & 39,2 & 0,3 & $<0,1$ & $<0,1$ & $<0,1$ & 2 & 11,4 & $<0,1$ \\
\hline AM 5 & $<0,1$ & 39,6 & 39 & 0,33 & $<0,1$ & $<0,1$ & 0,13 & 1,4 & 5,9 & $<0,1$ \\
\hline
\end{tabular}

Tabela 5.6 - Perda por calcinação das amostras

\begin{tabular}{c|c}
\hline Amostra & PPC \\
\hline AM 1 & 9,8 \\
\hline AM 2 & 11,3 \\
\hline AM 3 & 8,4 \\
\hline AM 4 & 9,9 \\
\hline AM 5 & 13,2 \\
\hline
\end{tabular}

Pelos teores de óxidos de ferro, titânio, alumínio e sílica, as amostras provavelmente apresentam 3 origens diferentes, uma para AM 1, 2 e 4 (cujos teores encontram-se sempre próximos), outra para AM 3 e uma terceira para AM 5, com teores diferentes das outras.

Os solos 1 e 2 e 4 parecem apresentar minerais máficos, pelos seus maiores tores de ferro, entre 10,7 e 11,4, levando à conclusão de que este solo provavelmente não foi formado pela rocha-mãe local, rica em minerais félsicos, devendo estes então se tratarem de solos coluvionares.

Quanto à perda por calcinação, que depende da quantidade de argilominerais, matéria orgânica e materiais amorfos; o maior valor da amostra 5, de 13,2, deve-se, provavelmente, ao seu maior teor de argilominerais.

\section{3}

\section{Caracterização mineralógica}

As Figuras 5.2 a 5.6 apresentam os resultados encontrados para as difrações de raio-x realizadas nas amostras preparadas pelo método do pó. Conforme já mencionado, a AM 5 contou ainda com ensaios para as amostras preparadas pelo método da lâmina orientada, cujos resultados estão dispostos nas Figuras 5.7 a 5.10 . 


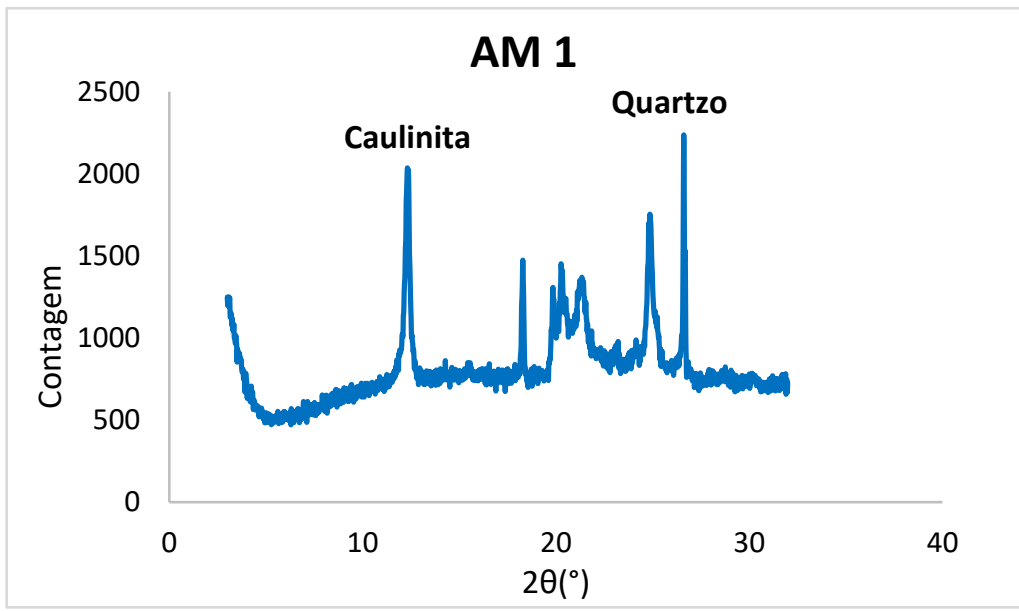

Figura 5.2 - Difratograma para a AM 1 (método do pó)

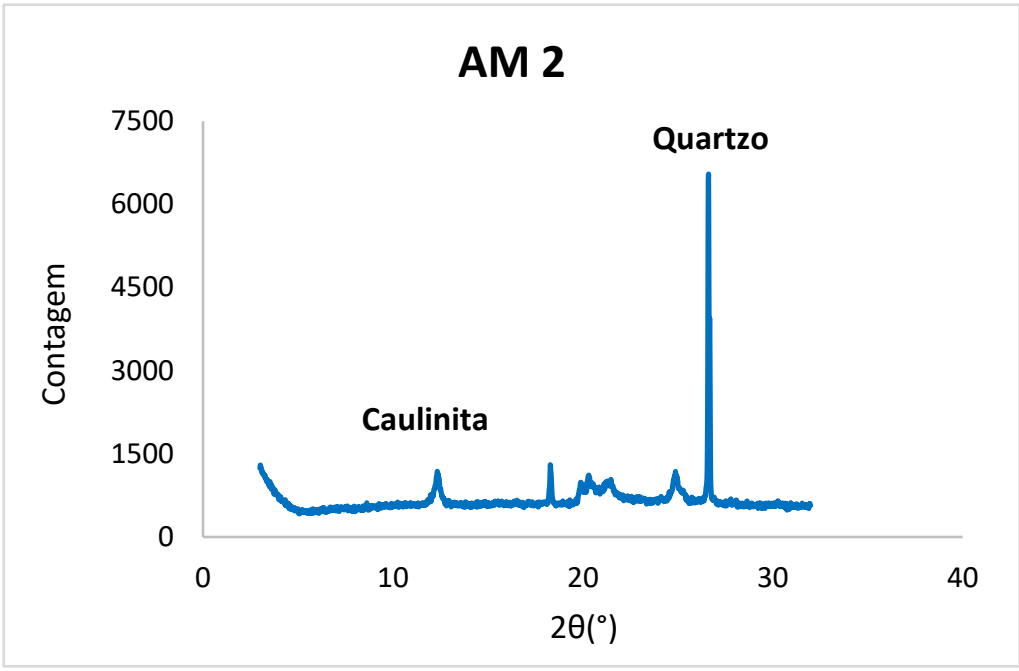

Figura 5.3 - Difratograma para a AM 2 (método do pó)

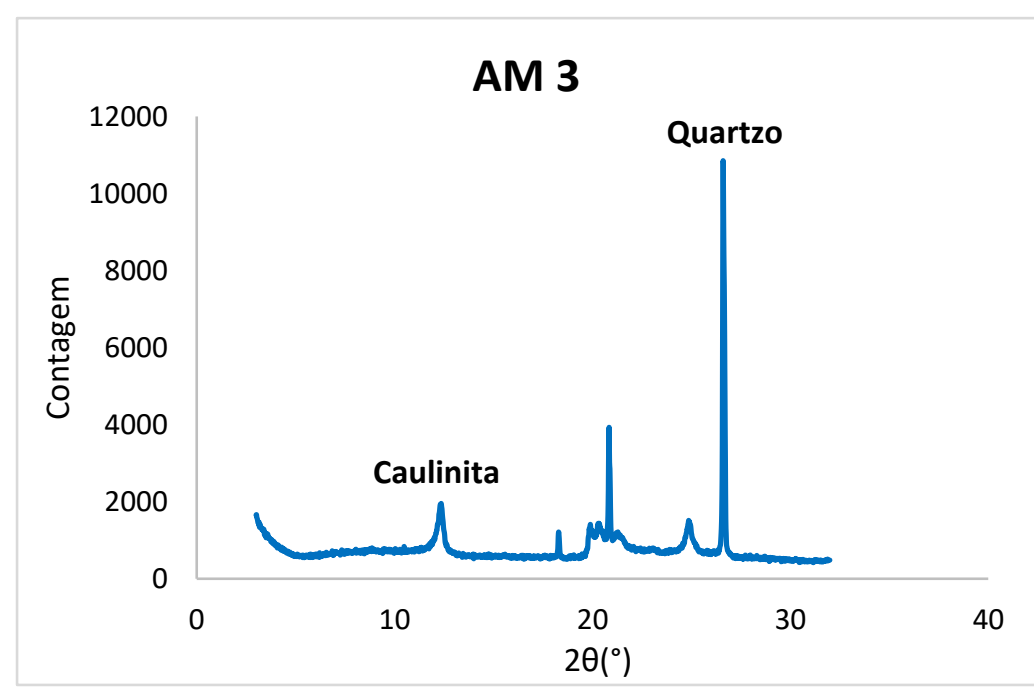

Figura 5.4 - Difratograma para a AM 3 (método do pó) 


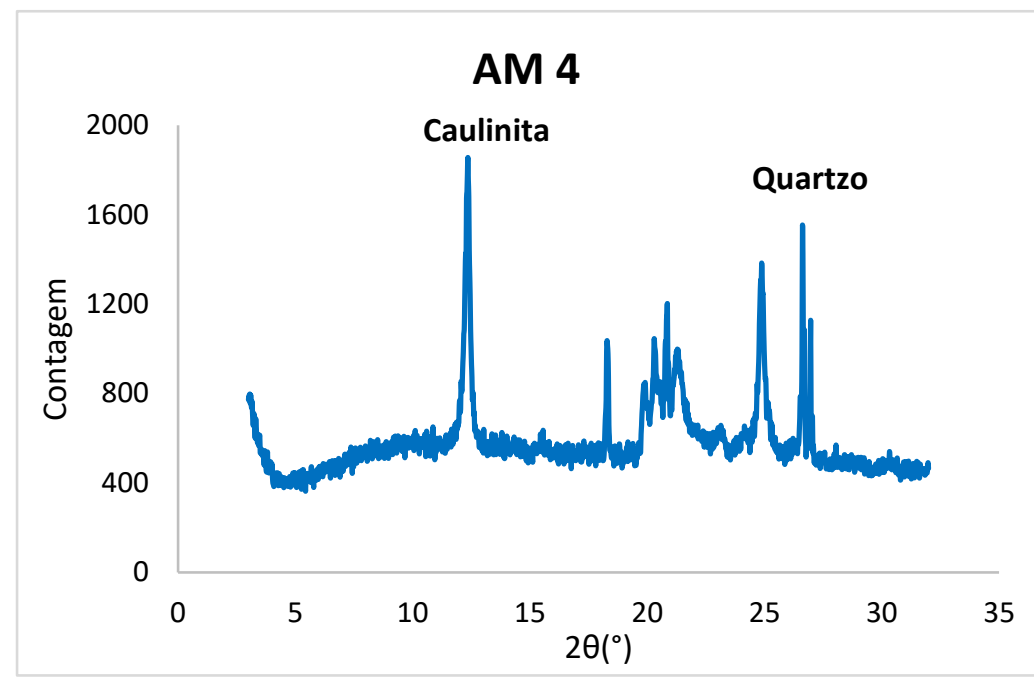

Figura 5.5 - Difratograma para a AM 4 (método do pó)

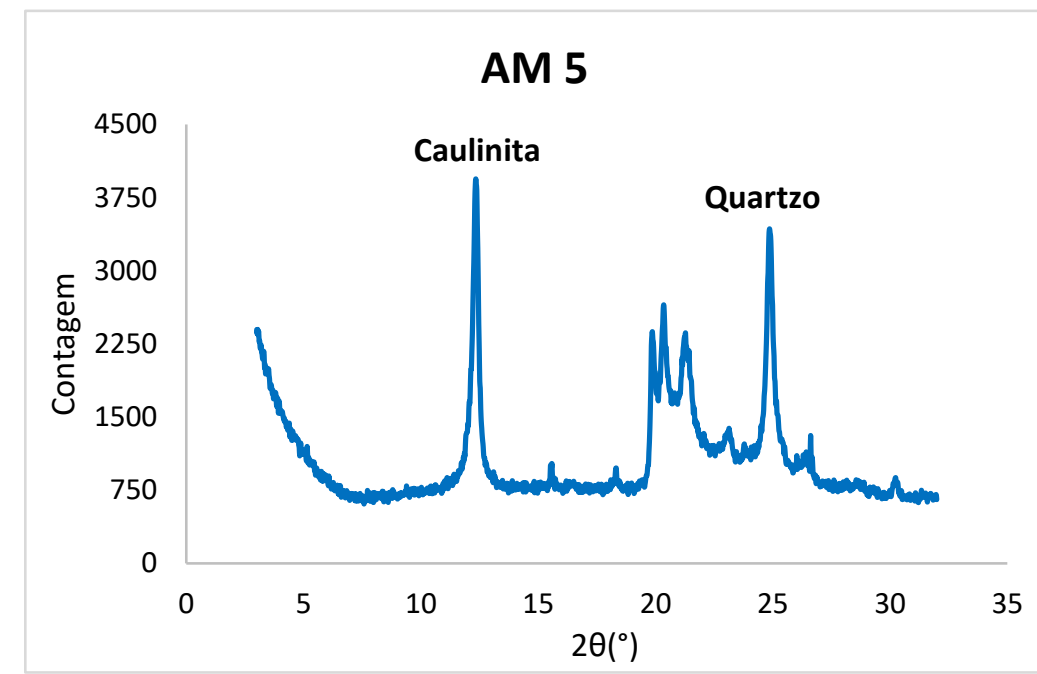

Figura 5.6 - Difratograma para a AM 5 (método do pó)

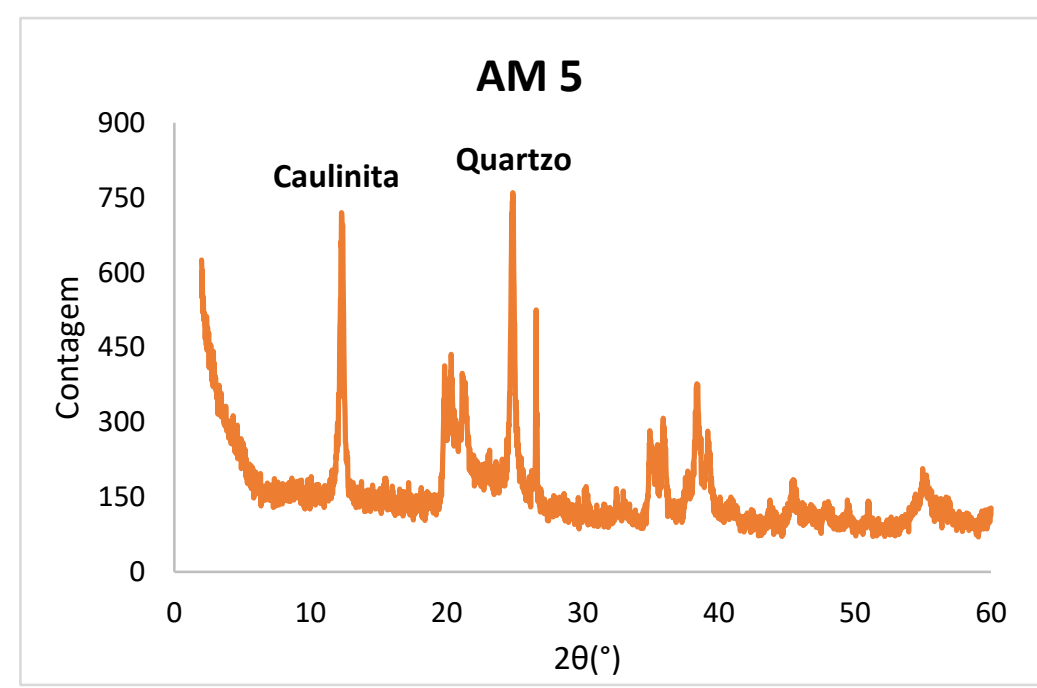

Figura 5.7 - Difratograma para a AM 5 (método da lâmina orientada) 


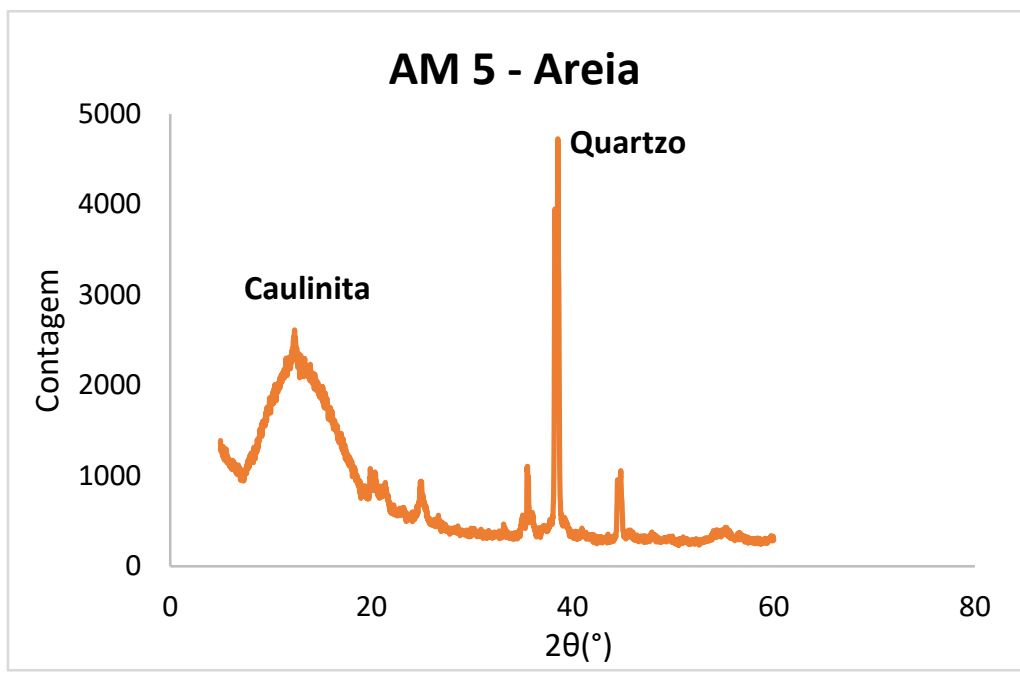

Figura 5.8 - Difratograma para a fração areia da AM 5 (método da lâmina orientada)

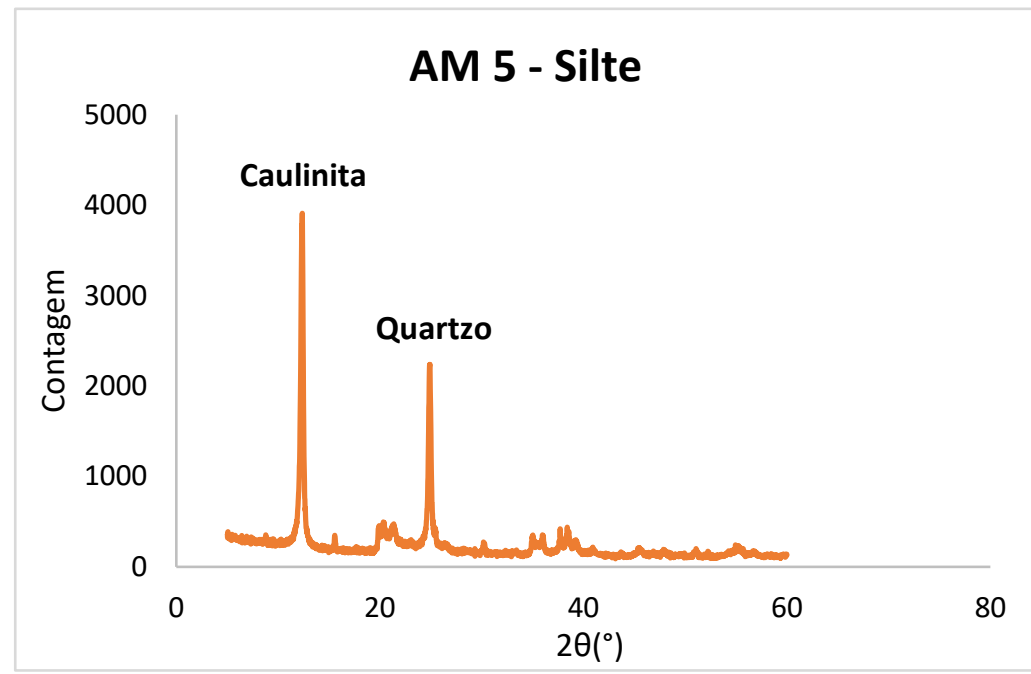

Figura 5.9 - Difratograma para a fração silte da AM 5 (método da lâmina orientada)

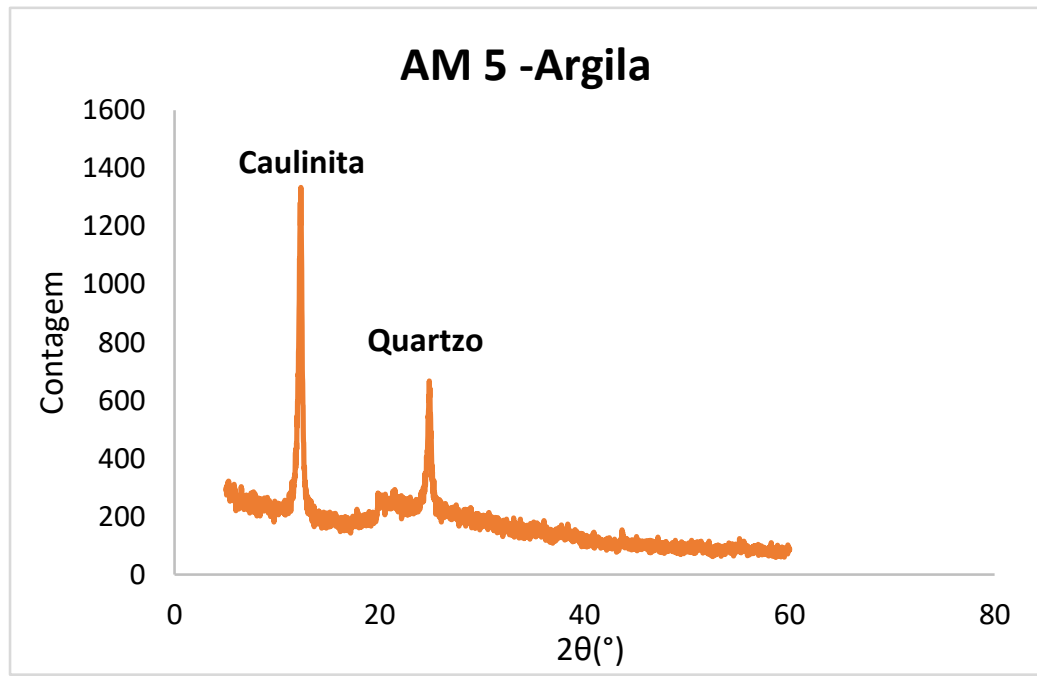

Figura 5.10 - Difratograma para a fração argila da AM 5 (método da lâmina orientada) 
Para as amostras em geral, predominam os argilominerais do grupo da caulinita. Os maiores teores de caulinita estariam nas amostras 1, 4 e 5, pelas alturas dos seus picos difratados principais. Os picos mais abaulados representam caulinita mal cristalizada e os simétricos e agudos, bem cristalizada (Antunes, 2018).

Nos ensaios com amostras preparadas pelo método da lâmina orientada, encontrou-se a presença de caulinita mal cristalizada na fração areia (Figura 4.8), o que pode the proporcionar a atividade média encontrada. Apesar de ter sido encontrada caulinita mal cristalizada nas amostras 2 e 3, estas apresentaram baixo teor (picos baixos).

\section{4 \\ Porosimetria de mercúrio}

As Figuras 4.11 a 4.13 mostram os resultados encontrados nos ensaios.

A divisão entre macroporos, mesoporos e microporos foi estabelecida tomando como base que os poros são aproximadamente 10x vezes menores que os grãos, com tamanhos conforme a NBR 6502/95:

- Microporos - relacionado à fração argila: menores que $2 \mu \mathrm{m}$;

- Mesoporos - relacionado à fração silte: entre 2 e $6 \mu \mathrm{m}$;

- Macroporos - relacionado à fração areia: maiores que $6 \mu \mathrm{m}$

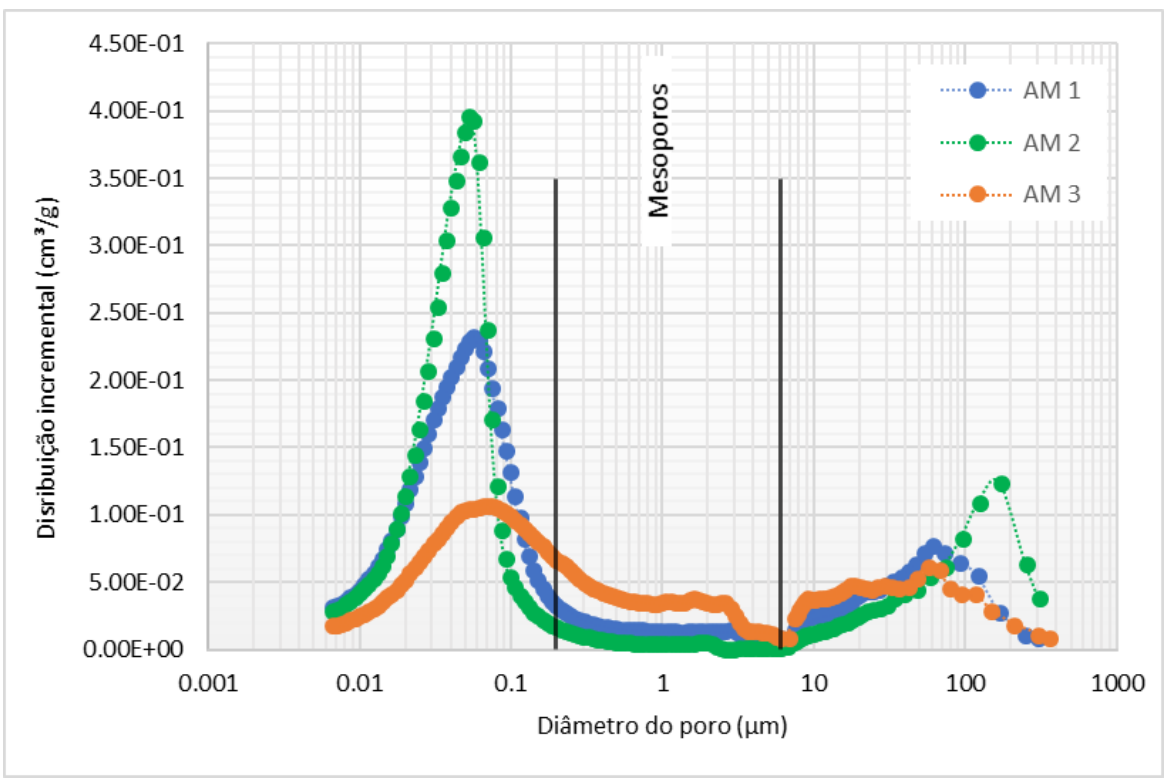

Figura 5.11 - Distribuição dos poros para as amostras 1 e 3 


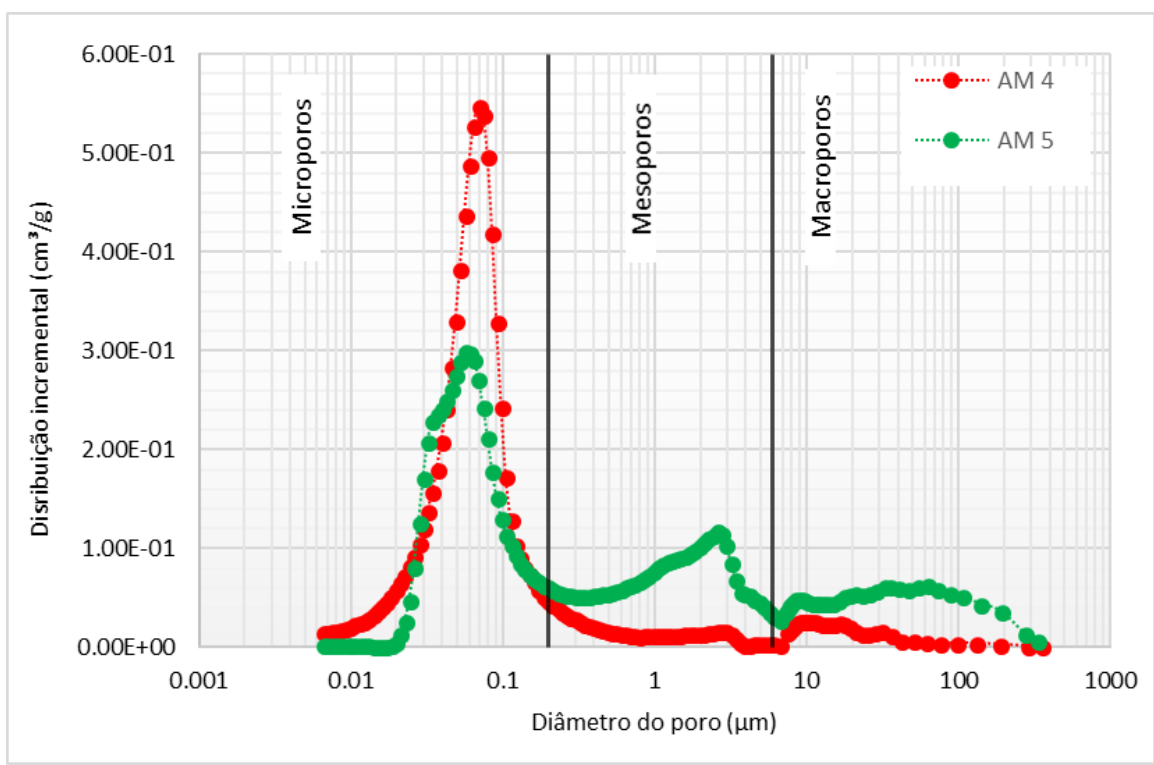

Figura 5.12 - Distribuição dos poros para as amostras 2, 4 e 5

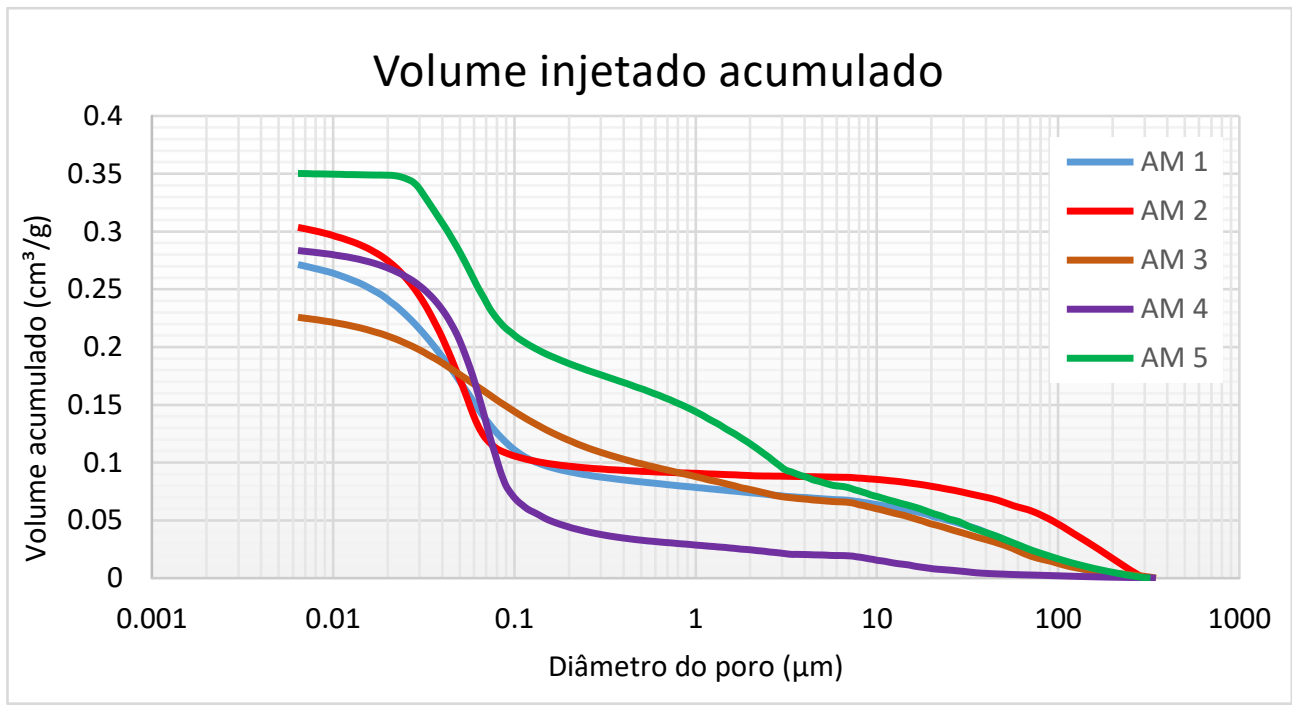

Figura 5.13 - Distribuição acumulada dos diâmetros dos poros

Observa-se que, para os solos das amostras 1 a 3, o comportamento é bimodal, apresentando picos bem definidos de macroporos e microporos, enquanto os solos 4 e 5 não apresentam picos nos macroporos, sendo classificado então como unimodais. A AM 5 teve o maior volume injetado acumulado, o que concorda com a maior porosidade encontrada para esta nos índices físicos.

Estes resultados serão utilizados para os ajustes nas curvas características de retenção de água, no item a seguir. 


\section{5}

\section{Curva característica de retenção de água}

Os resultados das médias entre topo e base para cada corpo de prova estão demonstrados nas Tabelas 5.7 e 5.8. Os dados obtidos pelo potenciômetro estão em vermelho e os obtidos pelo papel filtro em preto.

Tabela 5.7 - Dados obtidos nos ensaios das amostras 1 a 3

\begin{tabular}{c|c|c|c|c|c}
\hline \multicolumn{2}{c|}{ AM 1 } & \multicolumn{2}{c|}{ AM 2 } & \multicolumn{2}{c}{ AM 3 } \\
\hline $\begin{array}{c}\text { Umidade } \\
\text { volumétrica }\end{array}$ & $\begin{array}{c}\text { Sucçaão } \\
(\mathbf{k P a})\end{array}$ & $\begin{array}{c}\text { Umidade } \\
\text { volumétrica }\end{array}$ & $\begin{array}{c}\text { Sucção } \\
\text { (kPa) }\end{array}$ & $\begin{array}{c}\text { Umidade } \\
\text { volumétrica }\end{array}$ & $\begin{array}{c}\text { Sucção } \\
(\mathbf{k P a})\end{array}$ \\
\hline 0,059 & 18445,50 & 0,0551 & 19159,95 & 0,038 & 28864,09 \\
\hline 0,081 & 16338,58 & 0,0895 & 9559,44 & 0,089 & 10983,50 \\
\hline 0,125 & 10923,31 & 0,1718 & 6220,61 & 0,124 & 7948,98 \\
\hline 0,140 & 9288,75 & 0,2640 & 4475,38 & 0,157 & 4342,07 \\
\hline 0,198 & 5722,11 & 0,2716 & 1734,16 & 0,194 & 2777,79 \\
\hline 0,245 & 2951,50 & 0,3234 & 1197,34 & 0,234 & 1359,18 \\
\hline 0,261 & 2790,94 & 0,3387 & 887,49 & 0,243 & 250,00 \\
\hline 0,275 & 28,31 & 0,3438 & 178,74 & 0,282 & 100,00 \\
\hline 0,283 & 70,83 & 0,3643 & 68,92 & 0,294 & 57,62 \\
\hline 0,297 & 13,55 & 0,3985 & 8,65 & 0,294 & 42,01 \\
\hline 0,307 & 618,65 & 0,4053 & 22,25 & 0,302 & 63,79 \\
\hline 0,310 & 11,11 & 0,4393 & 4,88 & 0,344 & 18,09 \\
\hline 0,342 & 10,11 & 0,4702 & 4,96 & 0,360 & 12,28 \\
\hline 0,387 & 5,51 & - & - & 0,387 & 4,15 \\
\hline- & - & - & - & 0,411 & 4,68 \\
\hline
\end{tabular}


Tabela 5.8 - Dados obtidos nos ensaios das amostras 4 e 5

\begin{tabular}{c|c|c|c}
\hline \multicolumn{2}{c|}{ AM 4 } & \multicolumn{2}{c}{ AM 5 } \\
\hline $\begin{array}{c}\text { Umidade } \\
\text { volumétrica }\end{array}$ & $\begin{array}{c}\text { Sucção } \\
(\mathbf{k P a})\end{array}$ & $\begin{array}{c}\text { Umidade } \\
\text { volumétrica }\end{array}$ & $\begin{array}{c}\text { Sucção } \\
\text { (kPa) }\end{array}$ \\
\hline 0,040 & 19712,93 & 0,046 & 12164,12 \\
\hline 0,094 & 10318,08 & 0,097 & 11554,43 \\
\hline 0,194 & 7380,36 & 0,142 & 8434,96 \\
\hline 0,263 & 4181,89 & 0,167 & 9122,12 \\
\hline 0,329 & 3305,64 & 0,175 & 6348,04 \\
\hline 0,376 & 1988,38 & 0,275 & 4367,30 \\
\hline 0,377 & 410,00 & 0,309 & 1490,00 \\
\hline 0,387 & 210,00 & 0,311 & 1660,53 \\
\hline 0,419 & 47,82 & 0,339 & 1669,09 \\
\hline 0,421 & 18,88 & 0,379 & 869,88 \\
\hline 0,427 & 24,50 & 0,400 & 566,77 \\
\hline 0,431 & 142,52 & 0,410 & 354,67 \\
\hline 0,452 & 16,71 & 0,411 & 210,00 \\
\hline- & - & 0,440 & 48,19 \\
\hline- & - & 0,468 & 20,21 \\
\hline & & &
\end{tabular}

Os melhores ajustes das curvas foram encontrados pela metodologia proposta por Fredlund e Xing (1994), na qual os parâmetros de ajuste a, m e n são obtidos de acordo com as equações 5.4 a 5.8 e a Figura 5.14. Primeiramente, os dados experimentais devem ser ajustados para uma sucção máxima de $10^{6} \mathrm{kPa}$ com o parâmetro de correção (equações 5.2 e 5.3):

$$
\begin{aligned}
& \begin{array}{l}
\theta(\Psi, a, n, m)=C(\Psi) \frac{}{\ln } \\
C(\Psi)=1-\frac{\ln \left(1+\Psi / \Psi_{r}\right)}{\ln \left(1+10^{6} / \Psi_{r}\right)}
\end{array} \\
& a=\Psi_{i} \\
& m=3,67 \ln \left[\frac{\theta_{s} C\left(\Psi_{i}\right)}{\theta_{i}}\right] \\
& n=\frac{1,31^{m+1}}{m C\left(\Psi_{i}\right)} 3,72 s^{*}
\end{aligned}
$$

Sendo:

$$
S^{*}=\frac{s}{\theta_{s}}-\frac{\Psi_{i}}{1,31^{m}\left(\Psi_{i}-\Psi_{r}\right) \ln \left(1+10^{6} / \Psi_{r}\right)}
$$


$S=\frac{\theta_{i}}{\ln \left(\Psi_{p} / \Psi_{i}\right)}$

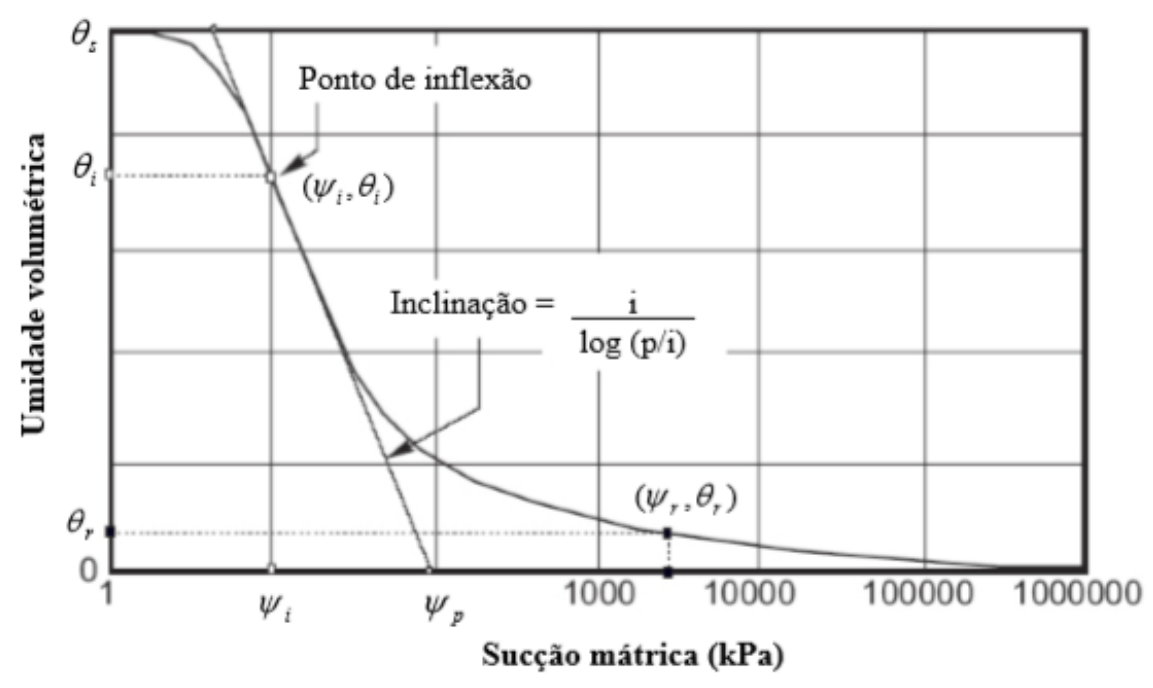

Figura 5.14 - Solução gráfica para determinação dos parâmetros de ajuste de Fredlund e Xing (1994) (Soares, 2005)

A definição se as curvas seriam unimodais ou bimodais deu-se a partir dos resultados da porosimetria de mercúrio, como já foi afirmado. Como os solos 1 a 3 apresentaram em sua estrutura macroporos e microporos, foram realizados ajustes bimodais. Para as amostras 4 e 5 , os ajustes foram unimodais, já que estes apresentaram apenas microporos em sua estrutura.

Utilizando-se o programa SVFlux (SoilVision, 2017), foram obtidas as curvas (Figuras 4.16 a 4.20), de onde foram retirados os parâmetros exibidos nas Tabelas 4.9 e 4.10 .

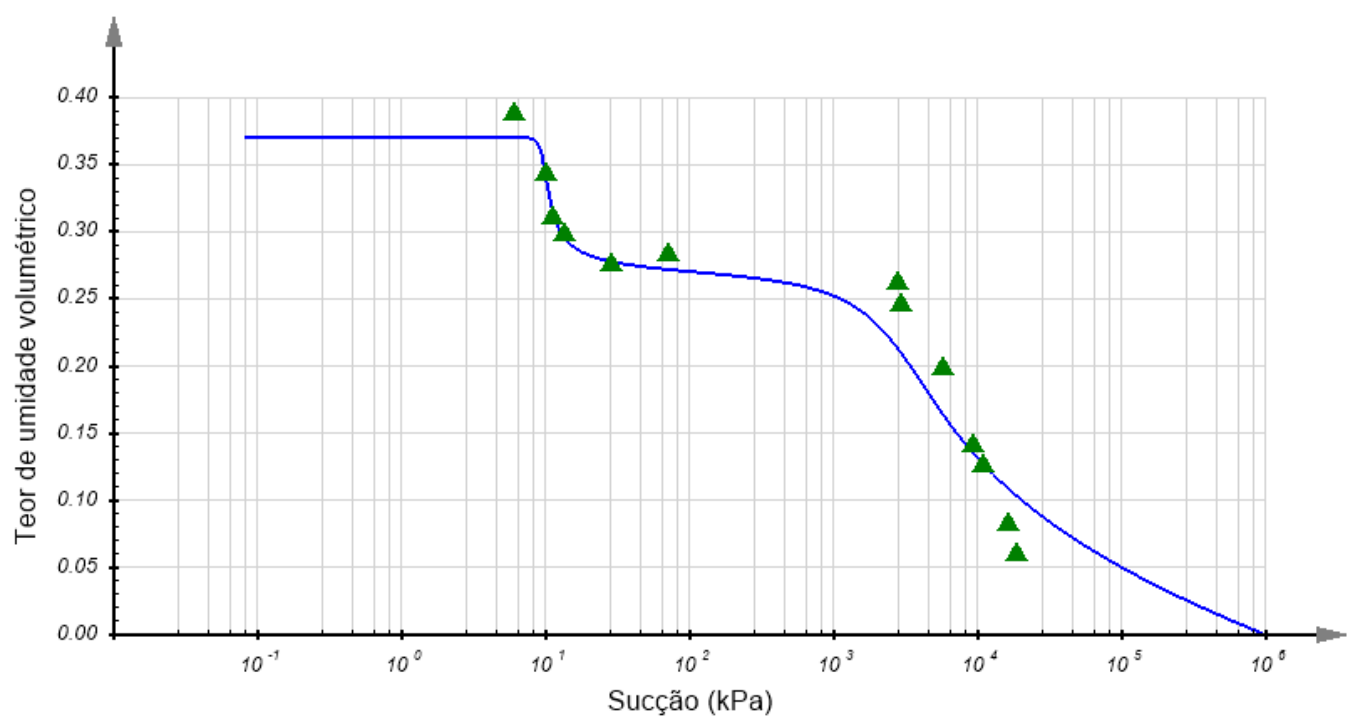

Figura 5.15 - Curva característica da amostra 1 


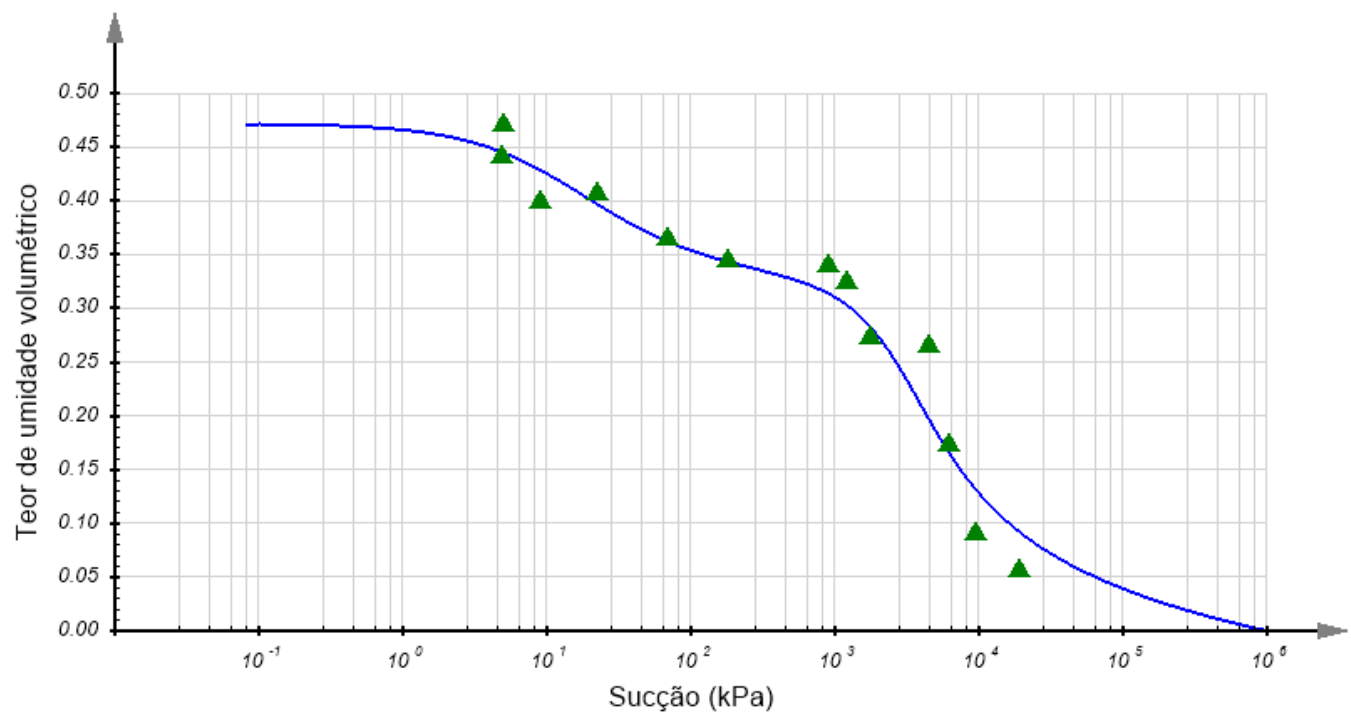

Figura 5.16 - Curva característica da amostra 2

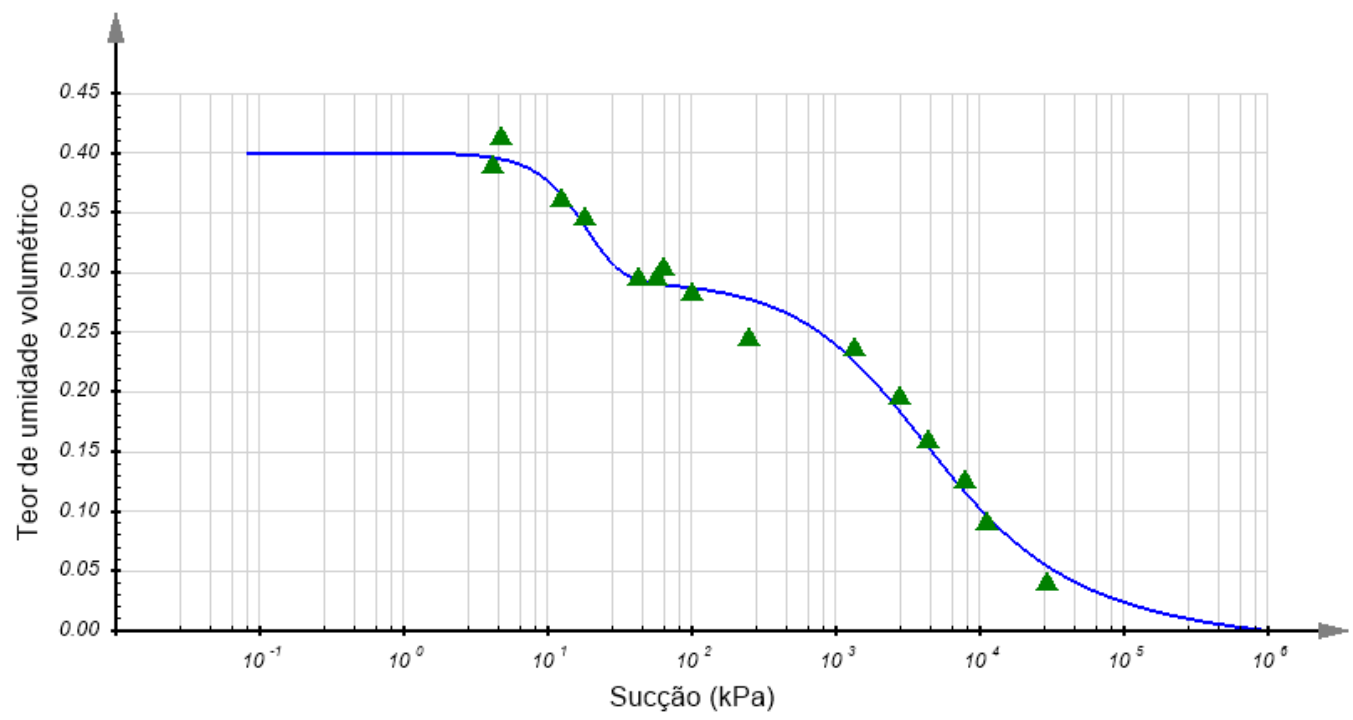

Figura 5.17 - Curva característica da amostra 3 


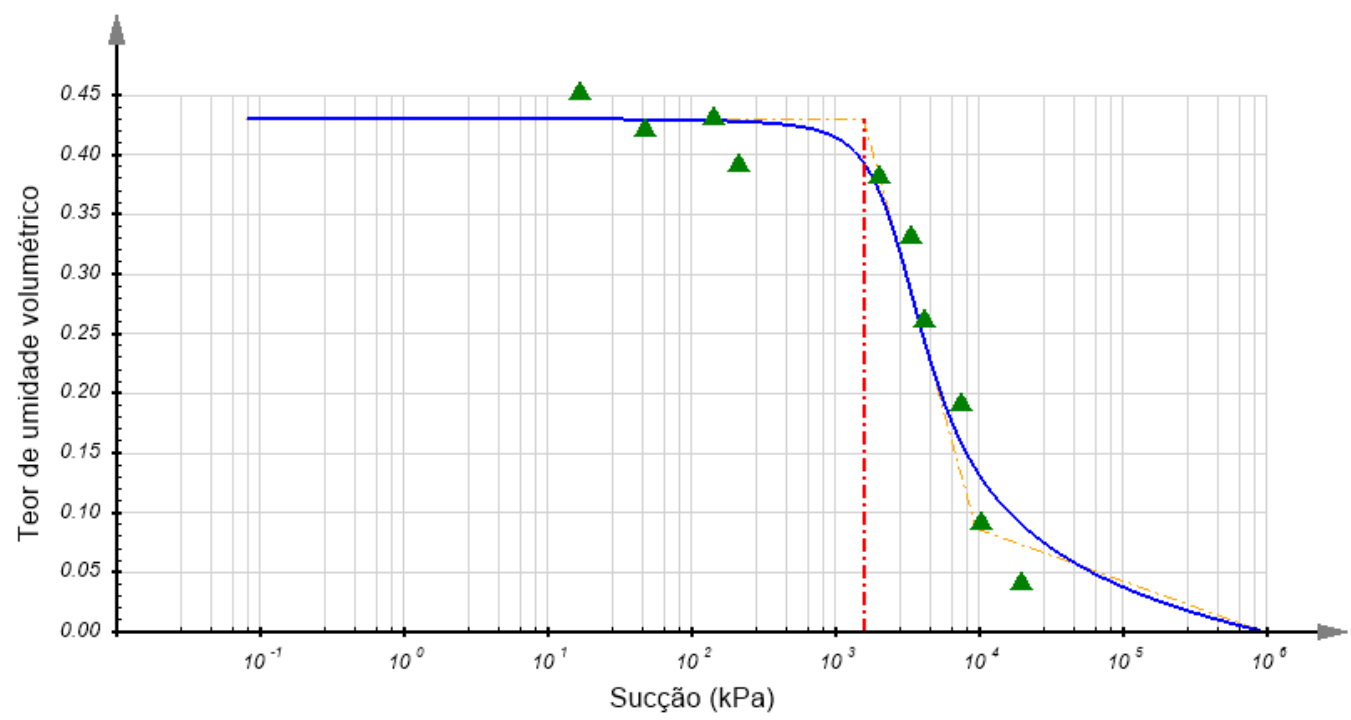

Figura 5.18 - Curva característica da amostra 4

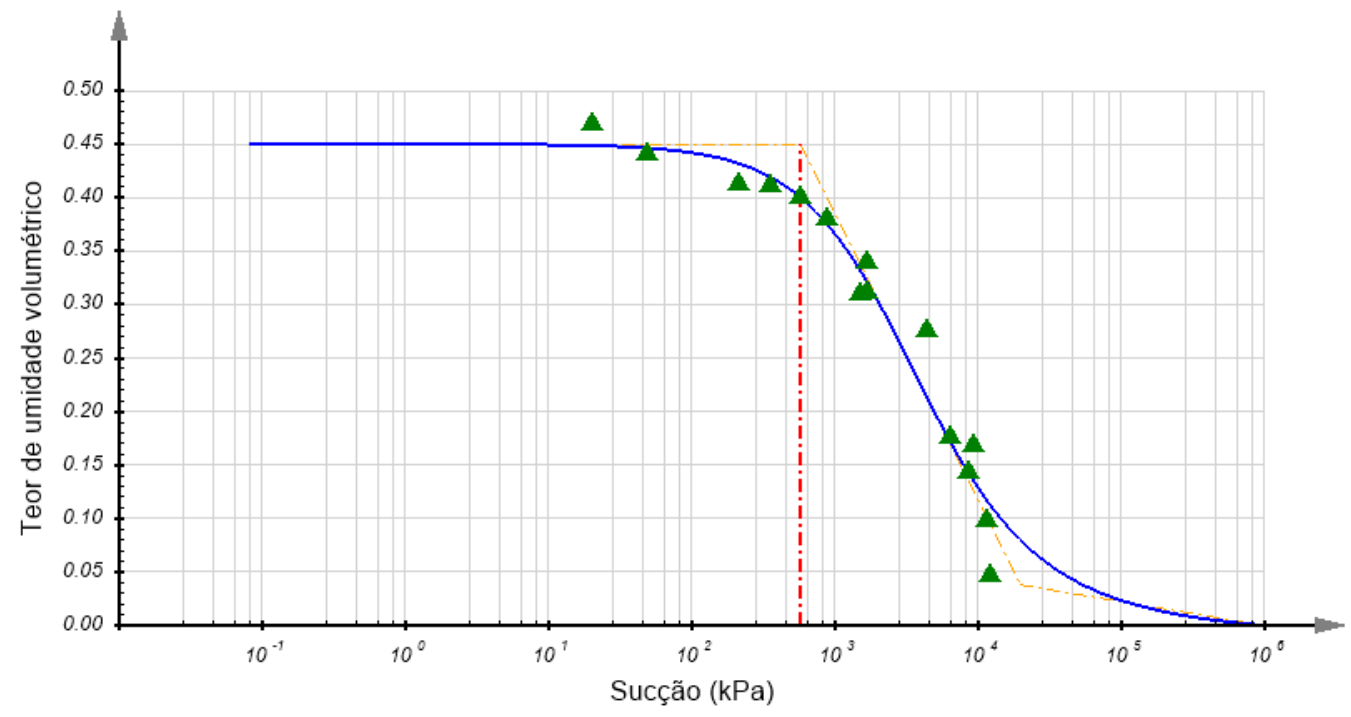

Figura 5.19 - Curva característica da amostra 5

Tabela 5.9 - Parâmetros de ajuste pelo método de Fredlund e Xing (1994).

\begin{tabular}{c|c|c|c|c}
\hline Amostra & $\mathbf{a}$ & $\mathbf{m}$ & $\mathbf{n}$ & $\boldsymbol{R}^{\mathbf{2}}$ \\
\hline AM 1 & 95,20 & 0,5976 & 20,000 & 0,9364 \\
\hline AM 2 & 13,48 & 17,785 & 10,540 & 0,9473 \\
\hline AM 3 & 31,23 & 84,670 & 22,137 & 0.9949 \\
\hline AM 4 & 2499,99 & 0,6986 & 30,741 & 0,9531 \\
\hline AM 5 & 2499,97 & 16,5350 & 11,109 & 0,9555 \\
\hline
\end{tabular}


Tabela 5.10 - Umidades volumétricas e sucções de entrada de ar e residuais para as amostras

\begin{tabular}{c|c|c|c|c|c|c|c|c}
\hline \multirow{2}{*}{ Amostra } & \multicolumn{4}{|c|}{ Macroporos } & \multicolumn{4}{c}{ Microporos } \\
\cline { 2 - 9 } & $\boldsymbol{\theta}_{\boldsymbol{s}}$ & $\boldsymbol{\Psi}_{\boldsymbol{s}}$ & $\boldsymbol{\theta}_{\boldsymbol{r}}$ & $\boldsymbol{\Psi}_{\boldsymbol{r}}$ & $\boldsymbol{\theta}_{\boldsymbol{s}}$ & $\boldsymbol{\Psi}_{\boldsymbol{s}}$ & $\boldsymbol{\theta}_{\boldsymbol{r}}$ & $\boldsymbol{\Psi}_{\boldsymbol{r}}$ \\
\hline AM 1 & 0,37 & 9,5 & 0,28 & 12,5 & 0,26 & 1450 & 0,089 & 10000 \\
\hline AM 2 & 0,47 & 2,4 & 0,36 & 60,0 & 0,32 & 1550 & 0,085 & 12500 \\
\hline AM 3 & 0,40 & 7,0 & 0,36 & 30,0 & 0,31 & 560 & 0,038 & 25000 \\
\hline AM 4 & - & - & - & - & 0,43 & 1450 & 0,087 & 10000 \\
\hline AM 5 & - & - & - & - & 0,45 & 530 & 0,038 & 16000 \\
\hline
\end{tabular}

Nota-se que todas as amostras apresentaram altos valores de umidade residual, a partir de $10.000 \mathrm{kPa}$, com a AM 3 se destacando das demais, com 25.000 $\mathrm{kPa}$. Os solos 1, 2 e 4 apresentaram umidades e sucções residuais próximas. 
6

Ensaios de resistência e permeabilidade

6.1

\section{Ensaios de resistência}

\subsection{1}

\section{Condição submersa}

A seguir, são apresentadas as curvas obtidas através dos ensaios de cisaIhamento direto na condição submersa (Figuras 6.1 a 6.5), bem como os parâmetros de resistência. A Tabela 6.1 mostra os dados iniciais, após adensamento e finais das amostras.

Tabela 6.1 - Índices físicos dos corpos de prova ensaiados na condição submersa

\begin{tabular}{|c|c|c|c|c|c|c|c|c|c|}
\hline \multirow[b]{2}{*}{ Amostra } & \multirow[b]{2}{*}{$\sigma(\mathrm{kPa})$} & \multicolumn{5}{|c|}{ Inicial } & \multirow{2}{*}{$\begin{array}{c}\text { AA } \\
\mathrm{e}\end{array}$} & \multicolumn{2}{|c|}{ Final } \\
\hline & & $\begin{array}{c}\gamma_{n a t} \\
\left(\mathbf{k N} / \mathbf{m}^{3}\right)\end{array}$ & $\begin{array}{c}\gamma_{d} \\
\left(\mathrm{kN} / \mathrm{m}^{3}\right) \\
\end{array}$ & e & w (\%) & S (\%) & & w (\%) & e \\
\hline \multirow{3}{*}{ AM 1} & 50 & 17,07 & 14,97 & 0,76 & 13,99 & 49,42 & 0,75 & 32,09 & 0,74 \\
\hline & 100 & 15,73 & 13,78 & 0,91 & 14,14 & 41,64 & 0,90 & 29,94 & 0,89 \\
\hline & 200 & 15,66 & 13,99 & 0,92 & 13,97 & 40,92 & 0,91 & 33,56 & 0,90 \\
\hline \multirow{3}{*}{ AM 2} & 50 & 14,92 & 13,95 & 0,95 & 6,99 & 20,35 & 0,94 & 30,92 & 0,94 \\
\hline & 100 & 15,51 & 12,74 & 1,14 & 21,75 & 53,07 & 1,12 & 35,02 & 1,10 \\
\hline & 200 & 16,06 & 13,16 & 1,07 & 22,03 & 57,17 & 1,02 & 33,00 & 1,01 \\
\hline \multirow{3}{*}{ AM 3} & 50 & 14,20 & 12,88 & 1,06 & 10,21 & 26,12 & 1,04 & 33,08 & 1,03 \\
\hline & 100 & 14,58 & 13,25 & 1,00 & 10,06 & 27,18 & 0,97 & 31,57 & 0,96 \\
\hline & 200 & 14,76 & 13,56 & 0,95 & 8,88 & 25,16 & 0,91 & 26,80 & 0,90 \\
\hline \multirow{3}{*}{ AM 4} & 50 & 17,54 & 14,25 & 0,91 & 23,08 & 70,26 & 0,89 & 34,98 & 0,88 \\
\hline & 100 & 17,30 & 13,93 & 0,96 & 24,20 & 70,26 & 0,94 & 33,20 & 0,93 \\
\hline & 200 & 15,71 & 13,44 & 1,03 & 16,93 & 45,74 & 1,00 & 30,92 & 0,99 \\
\hline \multirow{3}{*}{ AM 5} & 50 & 14,86 & 11,19 & 1,44 & 32,77 & 63,43 & 1,43 & 48,03 & 1,42 \\
\hline & 100 & 14,95 & 11,41 & 1,39 & 30,96 & 61,98 & 1,37 & 48,33 & 1,36 \\
\hline & 200 & 14,99 & 11,42 & 1,39 & 31,18 & 62,52 & 1,35 & 42,05 & 1,33 \\
\hline
\end{tabular}


Tensão cisalhante $\mathrm{x}$ Deslocamento horizontal

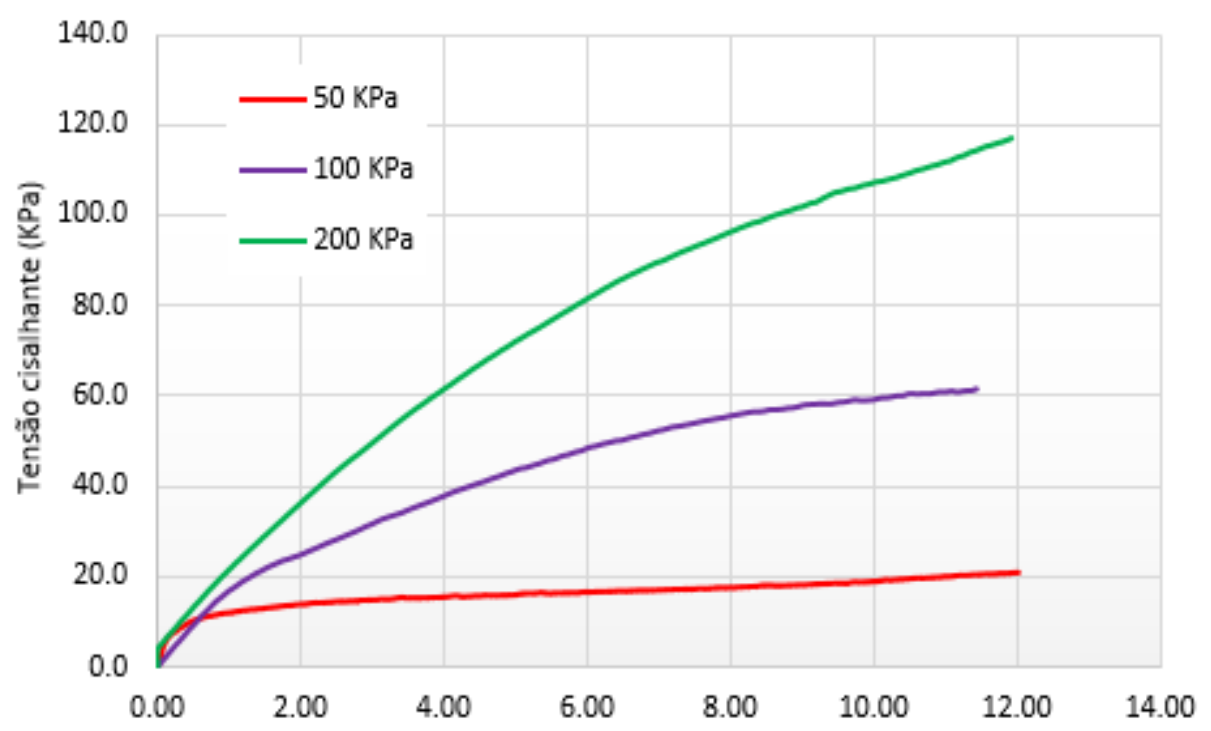

Deslocamento vertical $\mathrm{x}$ horizontal

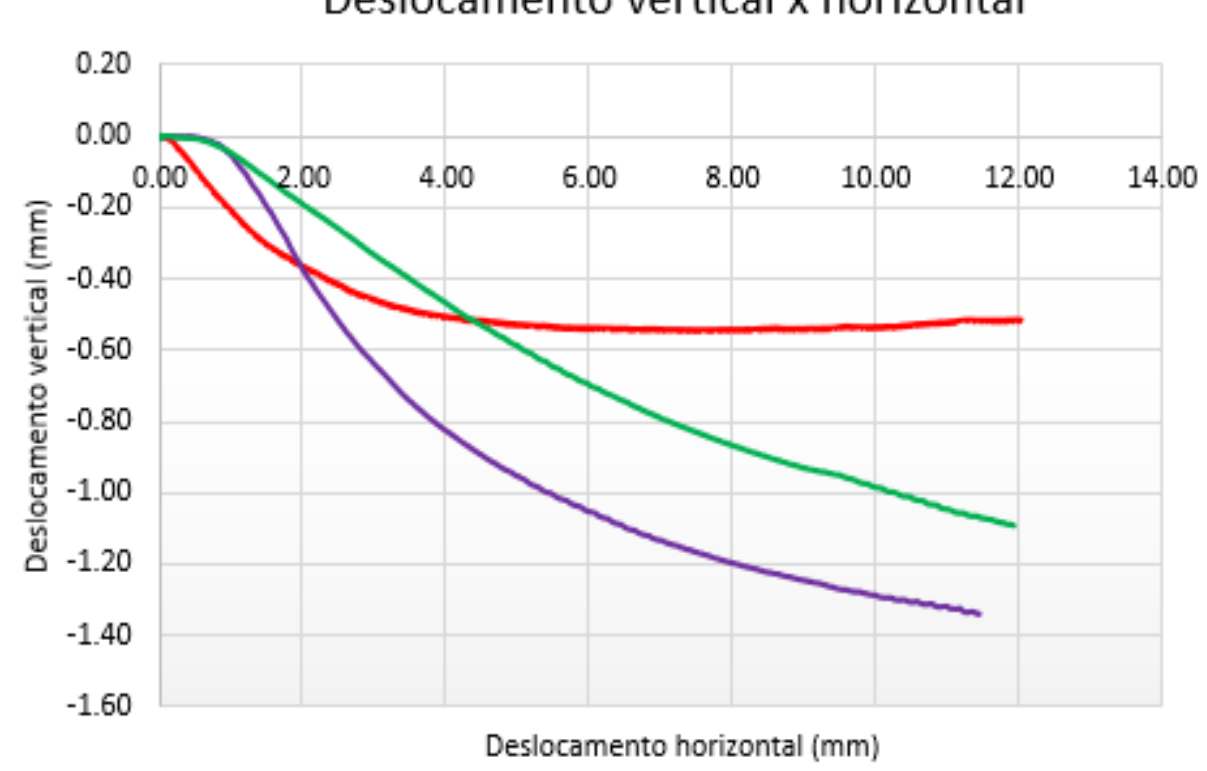

Figura 6.1 - Curvas para a amostra 1 

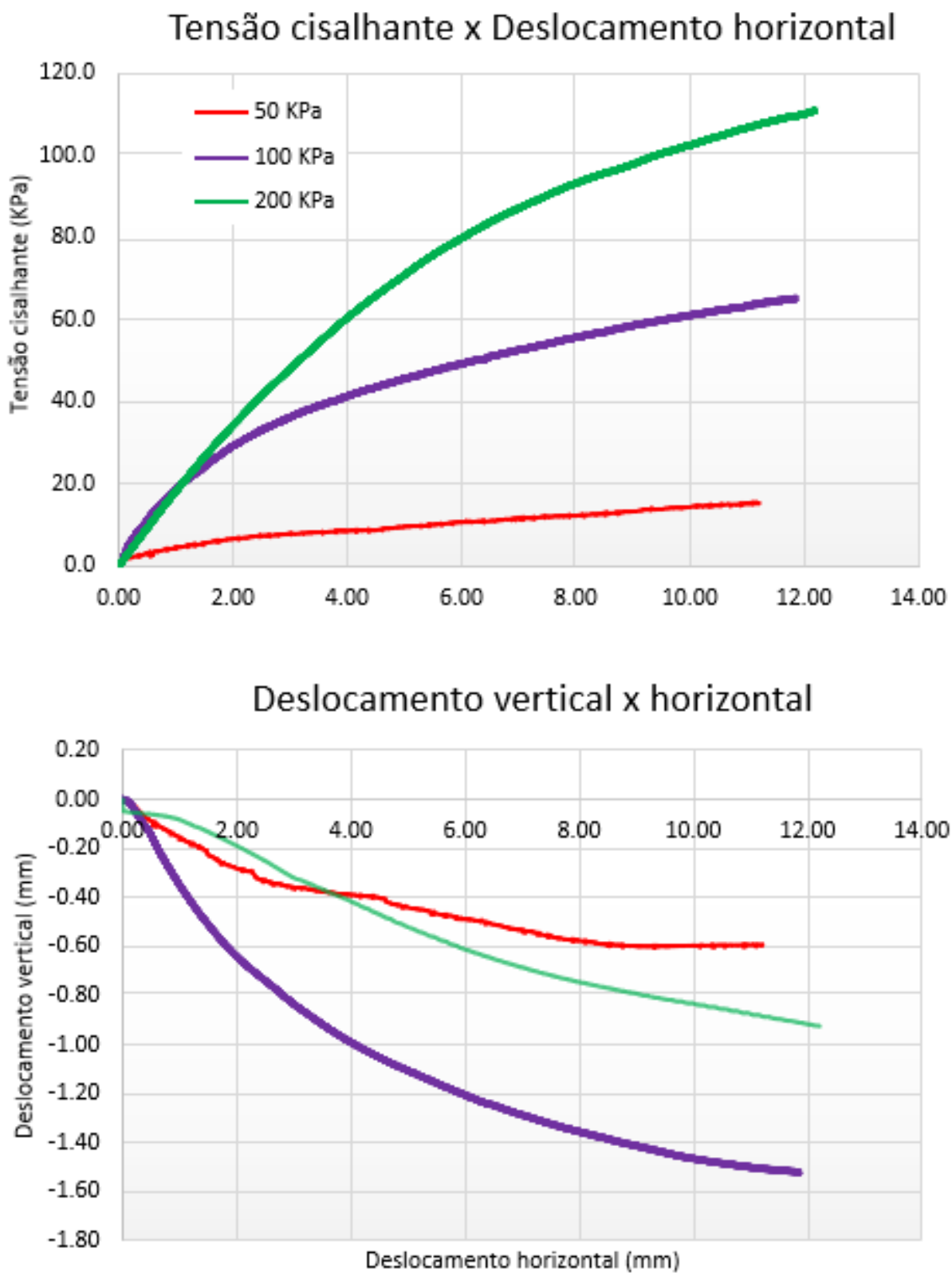

Figura 6.2 - Curvas para a amostra 2 

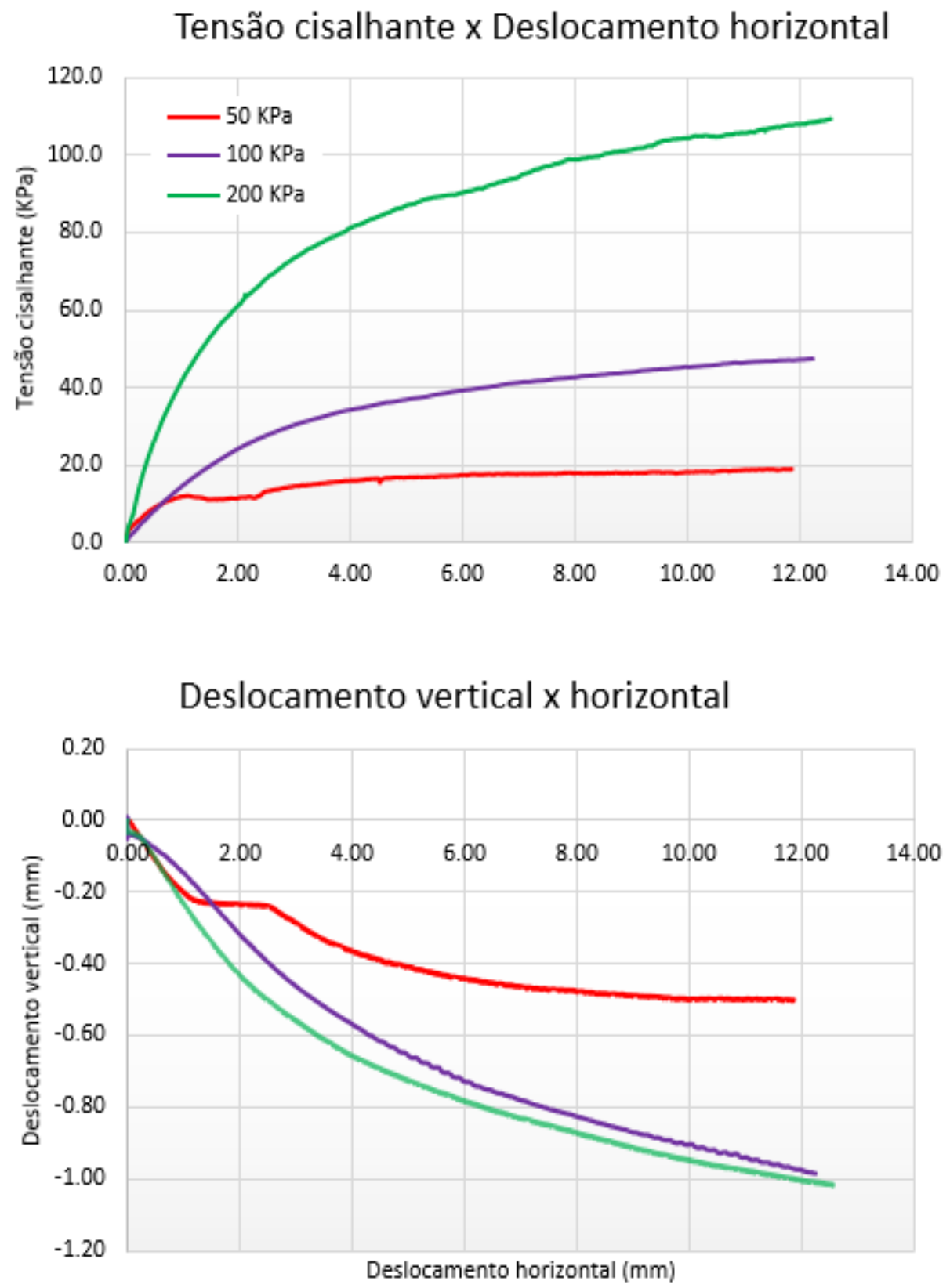

Figura 6.3 - Curvas para a amostra 3 


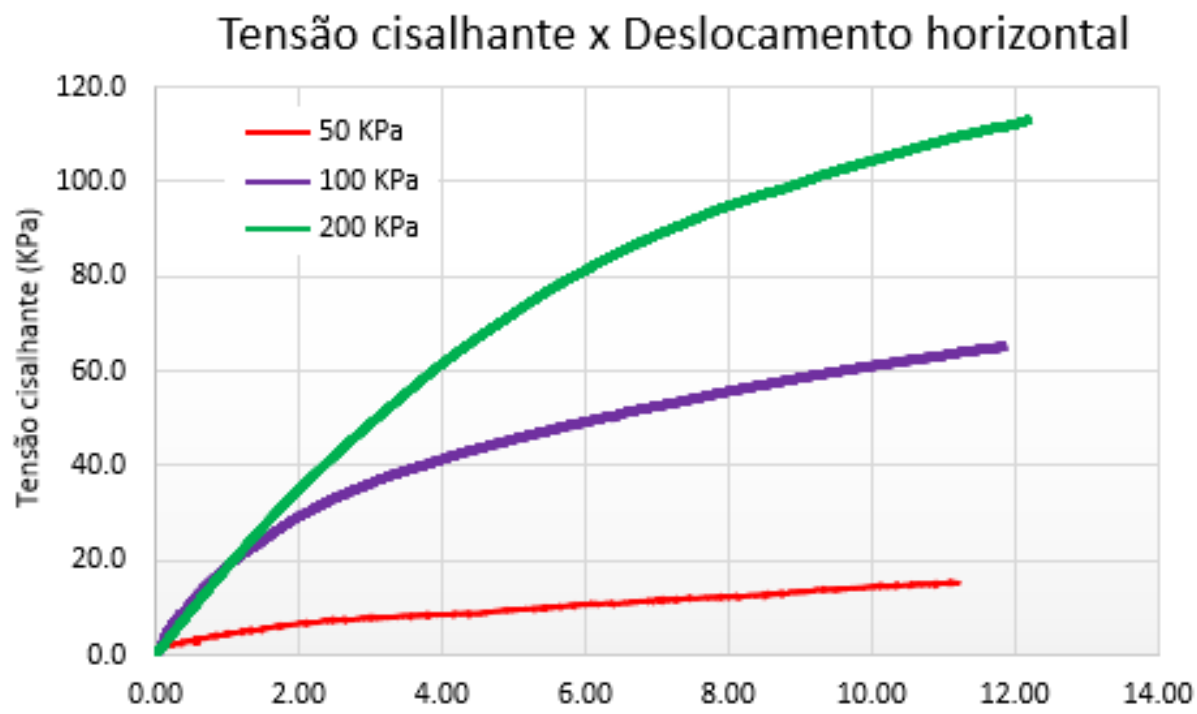

Deslocamento vertical $\mathrm{x}$ horizontal

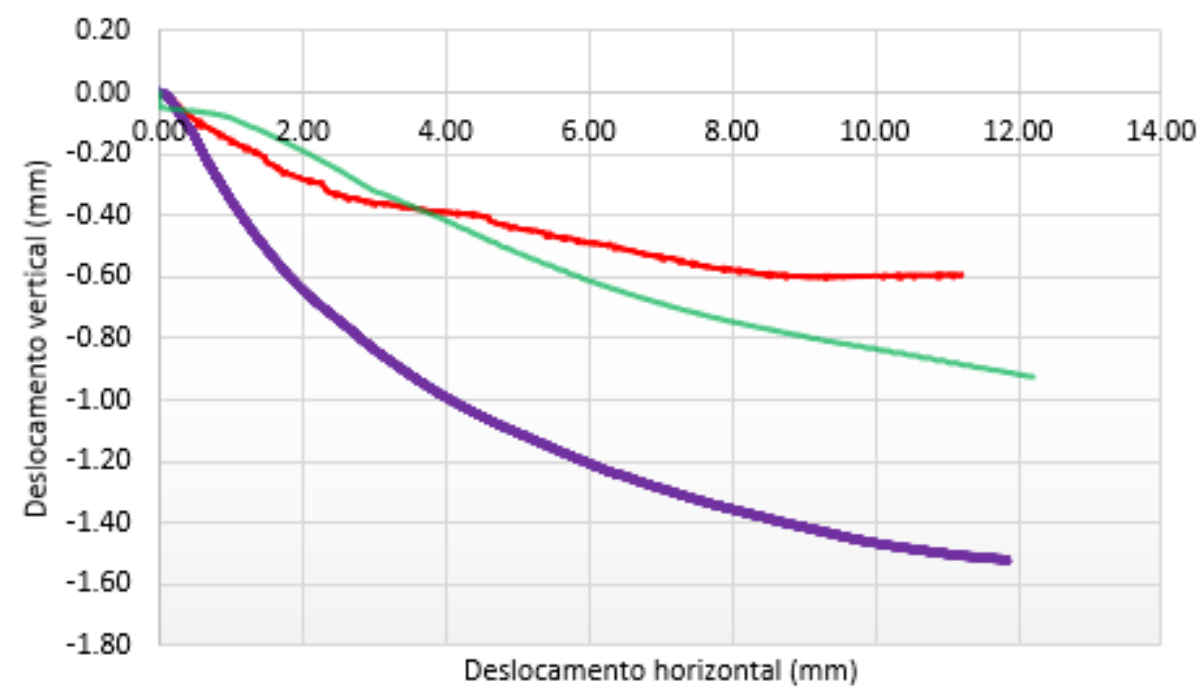

Figura 6.4 - Curvas para a amostra 4 

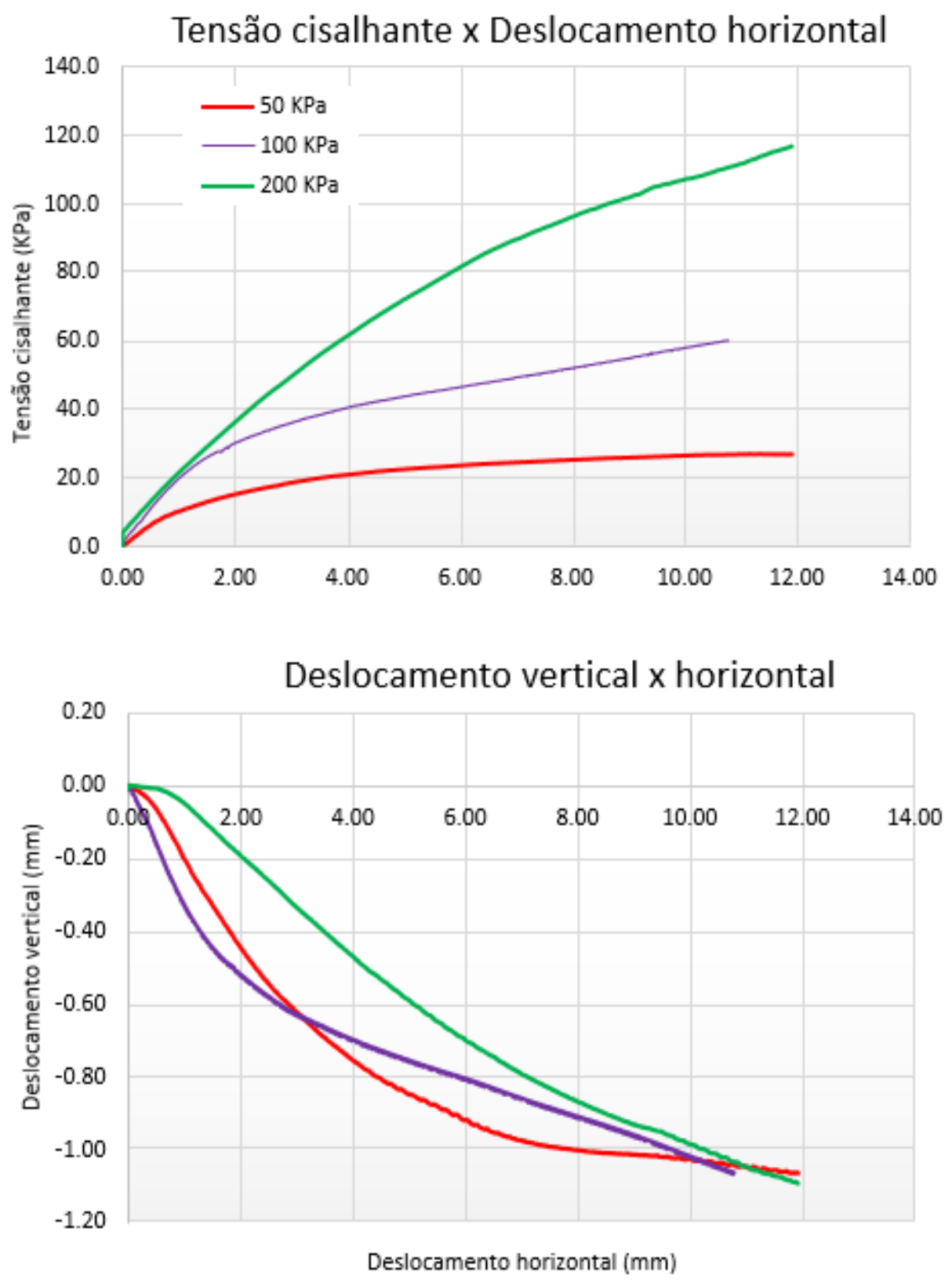

Figura 6.5 - Curvas para a amostra 5 
A Tabela 6.2 resume os valores de tensão normal inicial, tensões normal e cisalhante na ruptura e deslocamento na ruptura, determinadas pelo método de De Campos e Delgado (1995), descrito item 4.5.

Tabela 6.2 - Tensões normais de ensaio e dados da ruptura na condição submersa

\begin{tabular}{|c|c|c|c|c|}
\hline Amostra & $\sigma(k P a)$ & $\sigma_{r}(\mathrm{kPa})$ & $\tau_{r}(\mathrm{kPa})$ & $\delta_{r}(\mathrm{~mm})$ \\
\hline \multirow{3}{*}{ AM 1} & 50 & 52,5 & 13,8 & 1,95 \\
\hline & 100 & 106,2 & 55,1 & 7,88 \\
\hline & 200 & 210,7 & 92,3 & 7,39 \\
\hline \multirow{3}{*}{ AM 2} & 50 & 51,8 & 7,0 & 2,28 \\
\hline & 100 & 103,1 & 49,1 & 5,91 \\
\hline & 200 & 213,9 & 95,0 & 8,37 \\
\hline \multirow{3}{*}{ AM 3} & 50 & 51,9 & 15,3 & 3,54 \\
\hline & 100 & 106,0 & 42,2 & 7,65 \\
\hline & 200 & 209,6 & 98,2 & 7,77 \\
\hline \multirow{3}{*}{ AM 4} & 50 & 51,5 & 6,1 & 1,73 \\
\hline & 100 & 103,1 & 49,0 & 5,92 \\
\hline & 200 & 212,9 & 92,9 & 7,95 \\
\hline \multirow{3}{*}{ AM 5} & 50 & 53,0 & 22,4 & 4,93 \\
\hline & 100 & 102,3 & 41,7 & 4,34 \\
\hline & 200 & 209,8 & 95,3 & 7,85 \\
\hline
\end{tabular}

Pelos resultados, observou-se que as amostras 1, 2 e 4 eram compatíveis em termos de resistência, tendo sido determinada uma única envoltória para estas (Figura 6.6). O mesmo ocorreu com as amostras 3 e 5 (Figura 6.7):

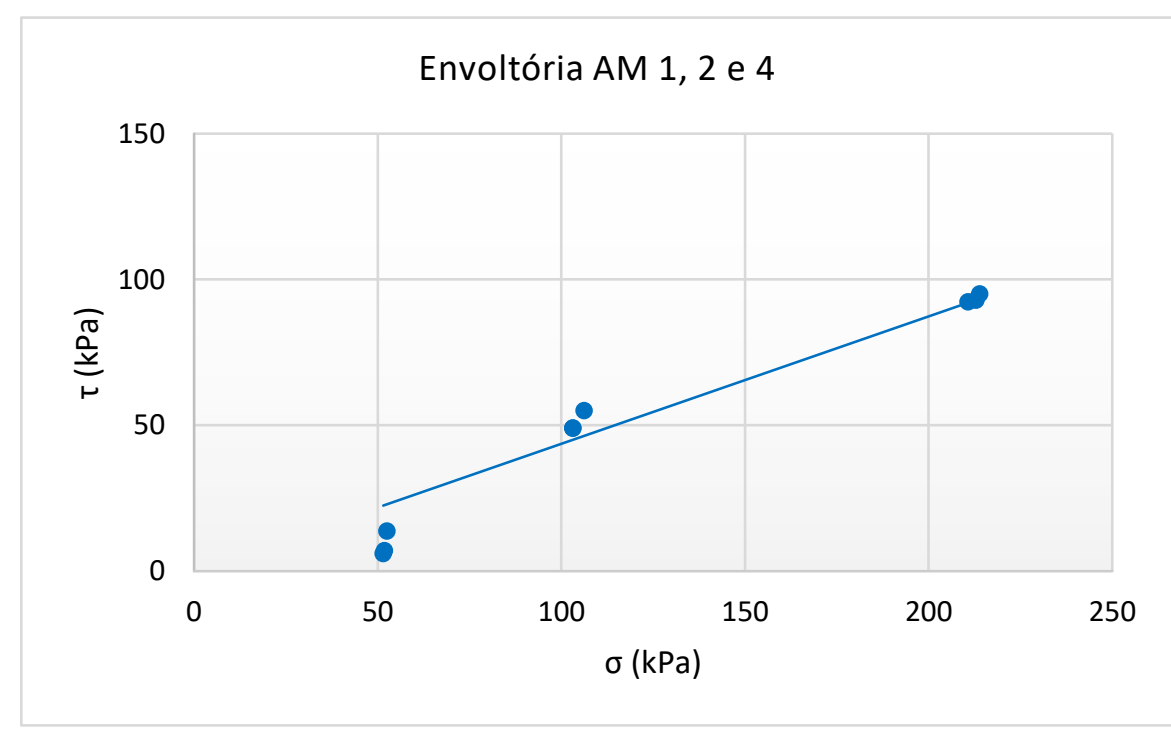

Figura 6.6 - Envoltórias obtidas pelos ensaios de cisalhamento direto na condição submersa para as amostras 1, 2 e 4 


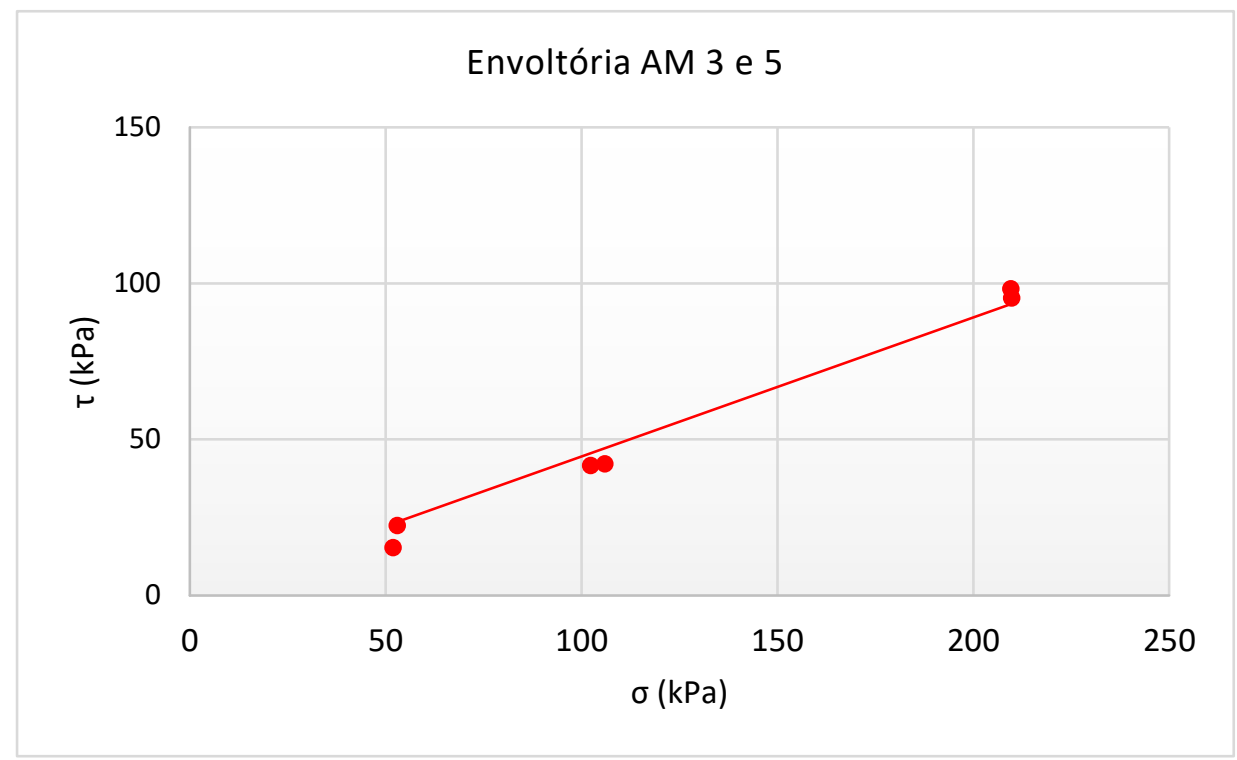

Figura 6.7 - Envoltórias obtidas pelos ensaios de cisalhamento direto na condição submersa para as amostras 3 e 5

A partir das envoltórias traçadas, foram encontrados os parâmetros de resistência da Tabela 6.3.

Tabela 6.3 - Parâmetros de resistência das amostras na condição submersa

\begin{tabular}{c|c|c|c}
\hline Amostra & $\mathbf{c}^{\prime}(\mathbf{k P a})$ & $\boldsymbol{\phi}^{\prime}\left(^{\circ}\right)$ & $\boldsymbol{R}^{\mathbf{2}}$ \\
\hline AM 1, 2 e 4 & 0 & 23,6 & 0,9799 \\
\hline AM 3 e 5 & 0 & 24,0 & 0,9434 \\
\hline
\end{tabular}

Nas amostras 1, 2 e 4, para a tensão normal de $50 \mathrm{kPa}$, foram encontradas baixas tensões de ruptura, aumentando a inclinação da envoltória e levando a um intercepto coesivo menor que zero, tendo este sido aproximado para tal, já que a situação encontrada não é real. Estes resultados também foram encontrados por Maia et al. (2017) e em ensaios realizados no Laboratório de Geotecnia da UFBA, para amostras na umidade natural coletadas na mesma região.

\section{1 .2}

\section{Condição seca}

As Figuras 6.8 a 6.10 apresentam as curvas obtidas pelos ensaios com amostras com umidade menor ou igual à residual. Foram ensaiadas as amostras 2,4 e 5 .

Para a AM 5, houve uma redução em suas dimensões na ordem de $2 \%$, por conta do procedimento de secagem ao ar, além do surgimento de pequenas fis- 
suras no corpo de prova, o que instigou a avaliação mais detalhada de sua mineralogia, conforme mencionado nos capitulos 4 e 5 . A redução de volume sofrida pelo solo foi computada no cálculo de seus índices físicos, expostos nas Tabelas 6.4 e 6.5 .

Tabela 6.4 - Índices físcos iniciais dos corpos de prova ensaiados na condição seca

\begin{tabular}{|c|c|c|c|c|c|c|c|}
\hline \multirow[b]{2}{*}{ Amostra } & \multirow{2}{*}{$\begin{array}{c}\sigma \\
(k P a)\end{array}$} & \multicolumn{6}{|c|}{ Inicial } \\
\hline & & $\begin{array}{c}\gamma_{n a t} \\
\left(\mathrm{KN} / \mathrm{m}^{3}\right)\end{array}$ & $\begin{array}{c}\gamma_{d} \\
\left(K N / m^{3}\right)\end{array}$ & e & w (\%) & $\theta(\%)$ & S (\%) \\
\hline \multirow{3}{*}{ AM 2} & 50 & 12,73 & 12,50 & 1,11 & 1,85 & 2,36 & 4,48 \\
\hline & 100 & 14,13 & 13,96 & 0,89 & 1,20 & 1,71 & 3,64 \\
\hline & 200 & 14,10 & 13,88 & 0,90 & 1,58 & 2,23 & 4,72 \\
\hline \multirow{3}{*}{ AM 4} & 50 & 14,05 & 13,90 & 0,95 & 1,10 & 1,56 & 3,21 \\
\hline & 100 & 14,25 & 14,10 & 0,92 & 1,05 & 1,51 & 3,16 \\
\hline & 200 & 14,28 & 13,84 & 0,96 & 3,15 & 4,44 & 9,10 \\
\hline \multirow{3}{*}{ AM 5} & 50 & 11,01 & 10,93 & 1,50 & 0,74 & 0,84 & 1,38 \\
\hline & 100 & 11,49 & 11,67 & 1,34 & 2,56 & 3,04 & 5,32 \\
\hline & 200 & 11,80 & 11,47 & 1,38 & 2,94 & 3,44 & 5,93 \\
\hline
\end{tabular}

Tabela 6.5 - Índices físicos após o adensamento e finais dos corpos de prova ensaiados na condição seca

\begin{tabular}{c|c|c|c|c}
\hline \multirow{2}{*}{ Amostra } & $\begin{array}{c}\text { Após } \\
\text { adensamento }\end{array}$ & \multicolumn{3}{|c}{ Final } \\
\cline { 2 - 5 } & $\mathbf{e}$ & $\mathbf{e}$ & $\mathbf{w}(\%)$ & $\boldsymbol{\theta}(\%)$ \\
\hline \multirow{3}{*}{ AM 2 } & 1,11 & 1,12 & 1,80 & 2,29 \\
\cline { 2 - 5 } & 0,89 & 0,90 & 1,31 & 1,86 \\
\cline { 2 - 5 } & 0,89 & 0,89 & 1,36 & 1,92 \\
\hline \multirow{3}{*}{ AM 4 } & 0,94 & 0,96 & 1,44 & 2,05 \\
\cline { 2 - 5 } & 0,91 & 0,92 & 1,14 & 1,65 \\
\cline { 2 - 5 } & 0,95 & 0,94 & 2,27 & 3,21 \\
\hline \multirow{3}{*}{ AM 5 } & 1,49 & 1,50 & 3,10 & 3,46 \\
\cline { 2 - 5 } & 1,33 & 1,34 & 4,04 & 4,80 \\
\cline { 2 - 5 } & 1,37 & 1,37 & 1,48 & 1,73 \\
\hline
\end{tabular}



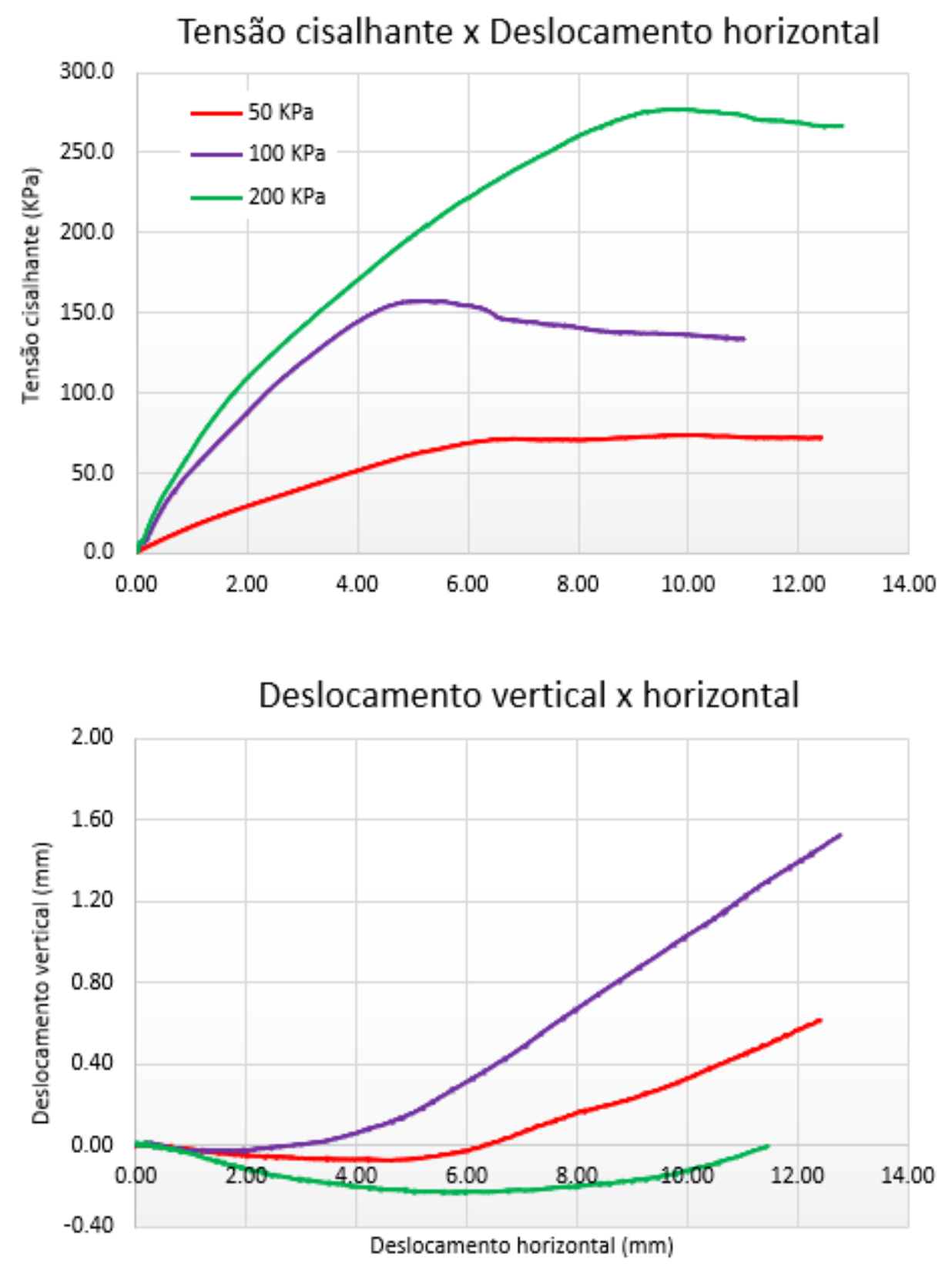

Figura 6.8 - Curvas para a amostra 2 


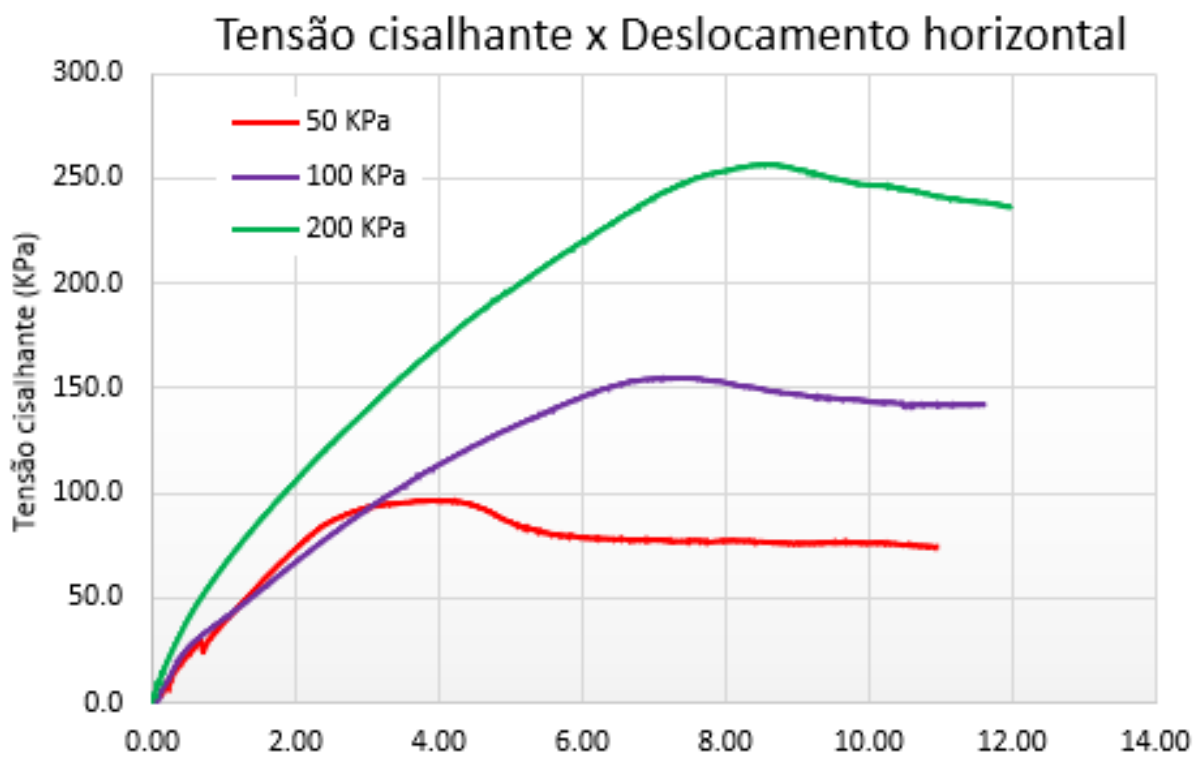

Deslocamento vertical $\mathrm{x}$ horizontal

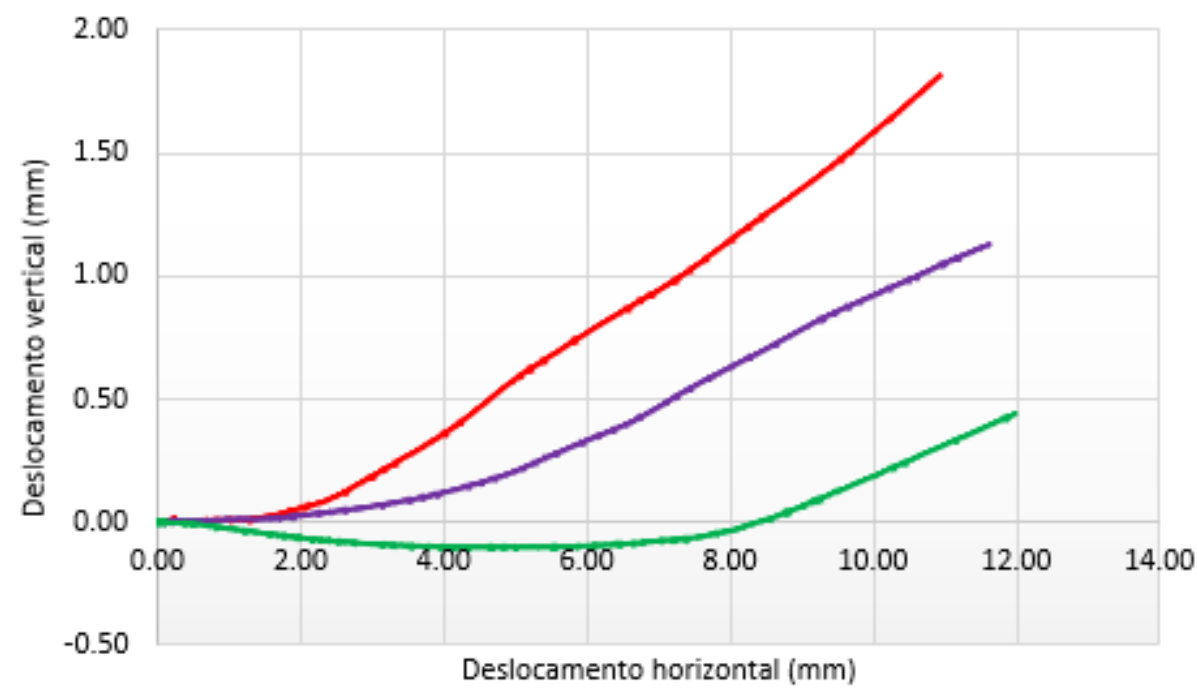

Figura 6.9 - Curvas para a amostra 4 

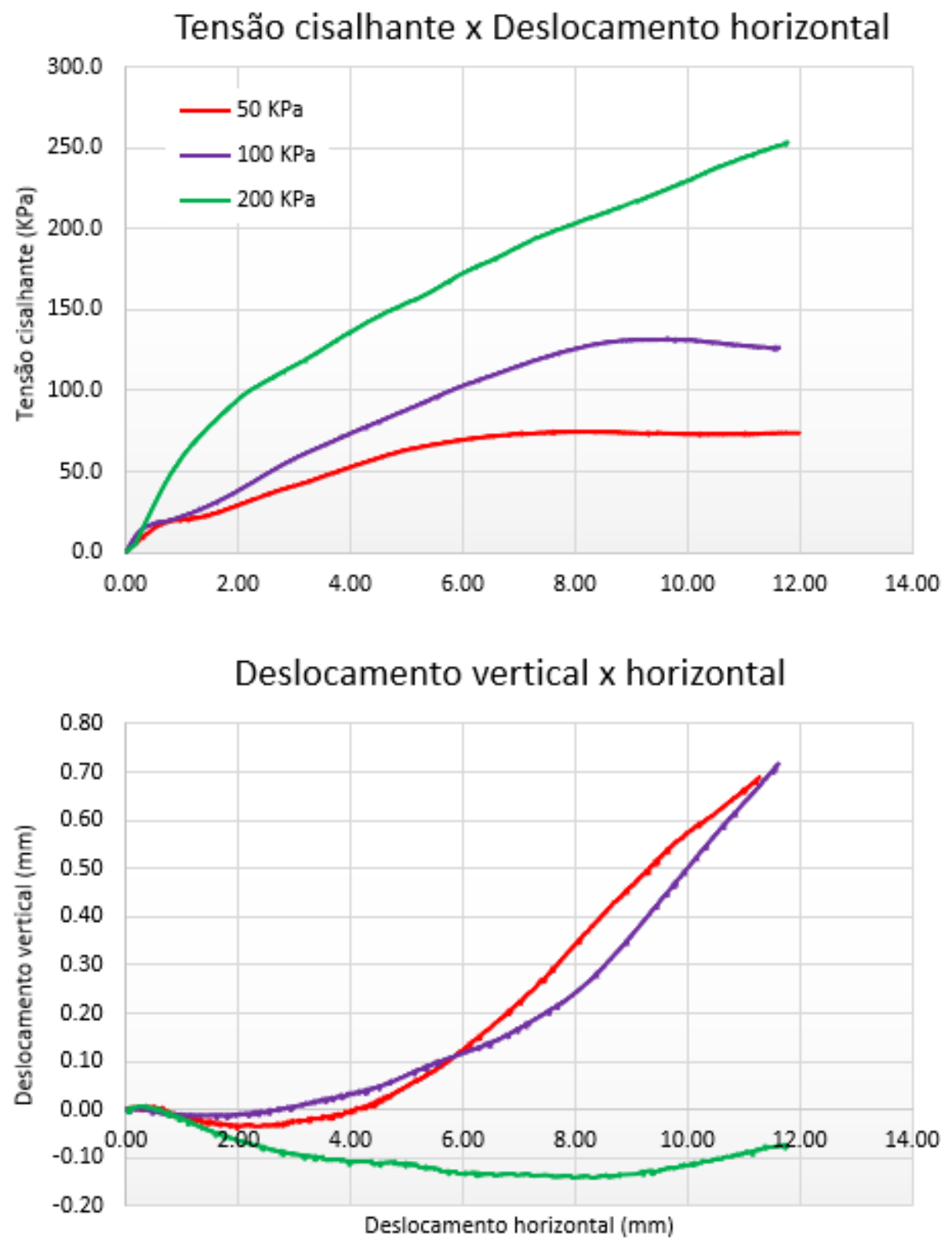

Figura 6.10 - Curvas para a amostra 5

Neste caso, as amostras apresentaram um aumento de volume, com picos pouco acentuados. Este comportamento pode ser associado à uma cimentação no solo nesta condição. Para a tensão normal de 200 kPa, a AM 5 voltou a não apresentar pico em sua curva tensão x deformação, tendo seu volume reduzido no ensaio. Assim, seus pares de tensões na ruptura foram definidos pelo método de De campos e Delgado (1995) e o restante pela tensão cisalhante de pico.

As tensões na ruptura, juntamente com os deslocamentos na ruptura obtidos nos ensaios, estão exibidos na Tabela 6.6. 
Tabela 6.6 - Tensões normais de ensaio e dados da ruptura na condição seca

\begin{tabular}{c|c|c|c|c}
\hline \multirow{2}{*}{ Amostra } & $\boldsymbol{\sigma}(\mathbf{k P a})$ & $\sigma_{\boldsymbol{r}}(\mathbf{k P a})$ & $\tau_{\boldsymbol{r}}(\mathbf{k P a})$ & $\boldsymbol{\delta}_{\boldsymbol{r}}(\mathbf{m m})$ \\
\hline \multirow{3}{*}{ AM 2 } & 50 & 56,1 & 74,4 & 10,13 \\
\cline { 2 - 5 } & 100 & 103,7 & 156,4 & 5,55 \\
\cline { 2 - 5 } & 200 & 213,8 & 276,7 & 9,93 \\
\hline \multirow{3}{*}{ AM 4 } & 50 & 52,4 & 97,0 & 3,94 \\
\cline { 2 - 5 } & 100 & 104,4 & 154,7 & 7,45 \\
\cline { 2 - 5 } & 200 & 213,3 & 256,5 & 8,54 \\
\hline \multirow{3}{*}{ AM 5 } & 50 & 55,1 & 75,1 & 8,25 \\
\cline { 2 - 5 } & 100 & 110,8 & 131,2 & 9,53 \\
\cline { 2 - 5 } & 200 & 216,6 & 191,9 & 7,15 \\
\hline
\end{tabular}

As envoltórias, representadas nas Figuras 6.12 e 6.13, foram determinadas usando o mesmo critério que na condição submersa, visto que os solos 2 e 4 também apresentaram resultados semelhantes. A Tabela 6.7 mostra os parâmetros de resistência obtidos.

Envoltória AM 2 e 4

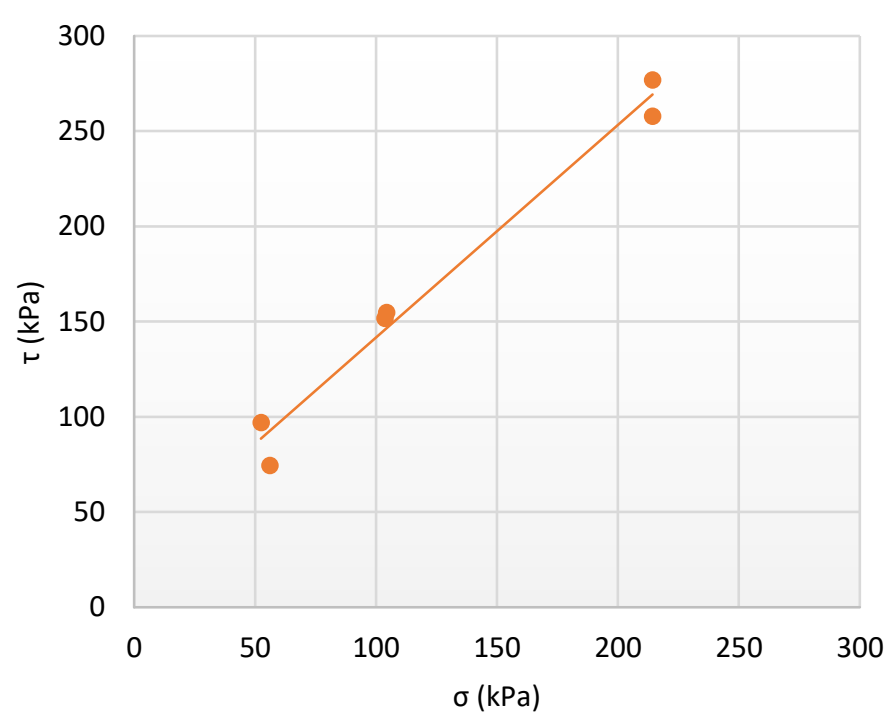

Figura 6.11 - Envoltória seca para as amostras 2 e 4 


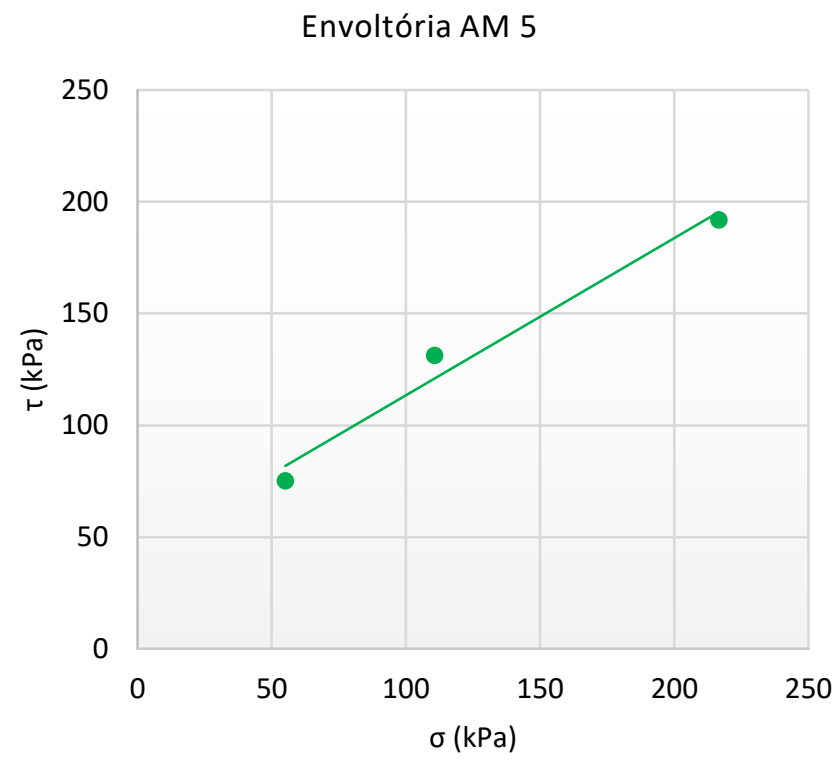

Figura 6.12 - Envoltória seca para a amostra 5

Tabela 6.7 - Parâmetros de resistência das amostras na condição seca

\begin{tabular}{c|c|c|c}
\hline Amostra & $\boldsymbol{c}_{\boldsymbol{u l t}}^{\prime}(\mathbf{k P a})$ & $\boldsymbol{\Phi}^{\prime}\left(^{\circ}\right)$ & $\boldsymbol{R}^{\mathbf{2}}$ \\
\hline AM 2 e 4 & 30,0 & 48,1 & 0,9797 \\
\hline AM 5 & 43,0 & 35,1 & 0,9761 \\
\hline
\end{tabular}

Os incrementos nos parâmetros de resistência ocorreram de formas diferentes entre os materiais. Na envoltória dos solos 2 e 4, o maior aumento foi visto no ângulo de atrito, que dobrou de valor; enquanto para a AM 5 o maior aumento se deu na coesão, que foi acrescida em cerca de $40 \mathrm{kPa}$.

\subsection{3}

\section{Envoltórias não saturadas}

Conforme já mencionado, as envoltórias não saturadas dos materiais foram estimadas pela proposta de Vilar (2006). Os resultados dos ensaios nas condições submersa e seca foram aplicados nas equações 2.10 e 2.12, chegando-se às envoltórias da Tabela 6.8 . 
Tabela 6.8 - Equações das envoltórias não saturadas

\begin{tabular}{c|c}
\hline Amostra & Envoltória não saturada \\
\hline AM 2 e 4 & $\tau=\frac{\left(u_{a}-u_{w}\right)}{2,2987+0,0333\left(u_{a}-u_{w}\right)}+\left(\sigma-u_{a}\right) \operatorname{tg} 23,60^{\circ}$ \\
\hline AM 5 & $\tau=\frac{\left(u_{a}-u_{w}\right)}{2,2513+0,0232\left(u_{a}-u_{w}\right)}+\left(\sigma-u_{a}\right) \operatorname{tg} 24,01^{\circ}$ \\
\hline
\end{tabular}

Substituindo-se a equação 2.8 pela parcela referente à coesão da equação deMohr-Coulomb, tem-se:

$$
\tau=c^{\prime}+\frac{\left(u_{a}-u_{w}\right)}{a+b\left(u_{a}-u_{w}\right)}+\left(\sigma-u_{a}\right) \tan \phi^{\prime}
$$

Comparando esta com a equação 2.6, conclui-se que:

$$
\tan \phi^{b}=\frac{1}{a+b\left(u_{a}-u_{w}\right)}
$$

Sendo possível assim obter os valores de $\phi^{b}$ em função da sucção mátrica, plotados nas Figuras 6.14 e 6.15 .

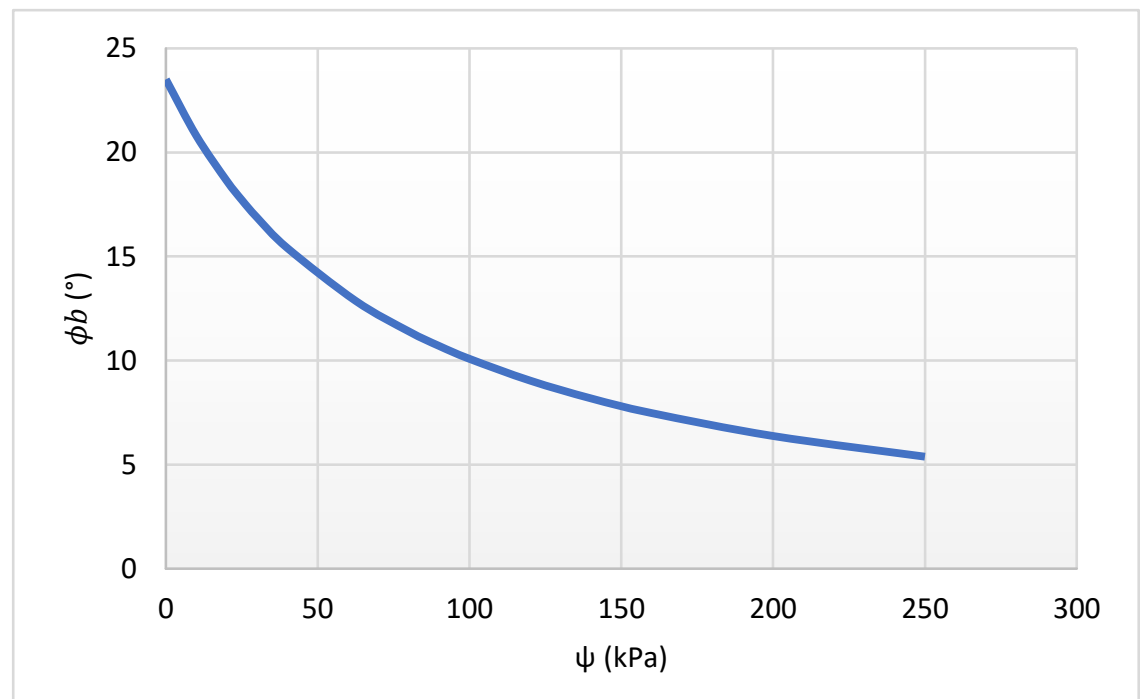

Figura 6.13 - Variação de $\phi^{b}$ em função da sucção para as amostras 2 e 4 


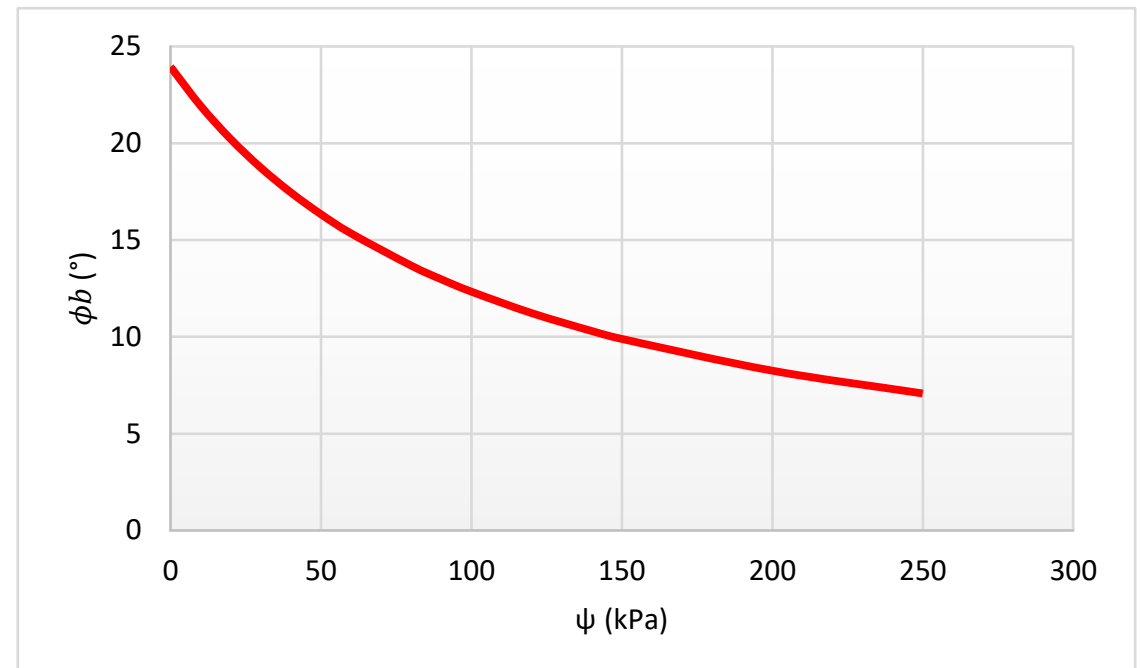

Figura 6.14 - Variação de $\phi^{b}$ em função da sucção para a amostra 5

\section{2}

\section{Ensaios de permeabilidade}

\subsection{1}

\section{Permeâmetro de Guelph}

Os resultados do permeâmetro de Guelph usados neste trabalho (Tabela 6.9) foram apresentados por Cajado e Campos (2017), calculados pela formulação proposta por Reynolds e Elrick (1985).

Tabela 6.9 - Condutividades hidráulicas saturadas obtidas pelo permeâmetro de Guelph, em cm/s (Adaptado de Cajado e Campos, 2017).

\begin{tabular}{c|c|c|c|c}
\hline Prof. (m) & G-1 $\left(^{*}\right)$ & AM 2 & AM 3 & AM 4 e 5 \\
\hline 0,60 & $2,52 \mathrm{E}-02$ & $2,54 \mathrm{E}-03$ & $8,80 \mathrm{E}-06$ & $1,88 \mathrm{E}-02$ \\
\hline 1,00 & $4,15 \mathrm{E}-04$ & $1,42 \mathrm{E}-04$ & $1,95 \mathrm{E}-03$ & $1,87 \mathrm{E}-03$ \\
\hline 2,00 & $1,81 \mathrm{E}-05$ & $3,19 \mathrm{E}-05$ & $4,20 \mathrm{E}-04$ & $4,72 \mathrm{E}-03$ \\
\hline 3,00 & $1,60 \mathrm{E}-04$ & - & - & $2,82 \mathrm{E}-04$ \\
\hline 4,00 & $1,40 \mathrm{E}-04$ & - & - & $8,15 \mathrm{E}-03$ \\
\hline 5,00 & $2,36 \mathrm{E}-04$ & - & - & $3,83 \mathrm{E}-03$ \\
\hline 6,00 & $1,09 \mathrm{E}-04$ & - & - & - \\
\hline
\end{tabular}

$\left({ }^{*}\right)$ Ver anexo II. 


\subsection{2}

\section{Permeâmetro de carga constante com parede flexível}

Para os ensaios de laboratório, conhecendo-se o gradiente hidráulico, a área da seção transversal à percolação e a vazão, a permeabilidade saturada de laboratório pode ser calculada pela Lei de Darcy. Os resultados estão exibidos na Tabela 6.10: flexíve

Tabela 6.10 - Condutividades hidráulicas saturadas obtidas pelo permeâmetro de parede

\begin{tabular}{c|c}
\hline Amostra & $\mathbf{k}(\mathbf{c m} / \mathbf{s})$ \\
\hline AM 1 & $7,47 \mathrm{E}-06$ \\
\hline AM 2 & $1,51 \mathrm{E}-04$ \\
\hline AM 3 & $3,89 \mathrm{E}-06$ \\
\hline AM 4 & $6,45 \mathrm{E}-05$ \\
\hline AM 5 & $4,58 \mathrm{E}-05$ \\
\hline
\end{tabular}

Percebe-se que as condutividades hidráulicas de campo são cerca de 2 ordens de grandeza maiores que as de laboratório, exceto para a AM 3, que apresentou a mesma ordem de grandeza para os dois casos. Este resultado pode ser justificado pelo fato dos ensaios de laboratório não levarem em conta a configuração do maciço, que pode conter fissuras, buracos e raízes e, por ser um maciço heterogêneo, a condutividade hidráulica pode variar consideravelmente para cada ponto. Além disto, a saturação do corpo de prova para realização do ensaio é melhor controlada em laboratório que em campo.

Para os ensaios realizados no G-1, AM 2 e AM 4 e 5, foram encontradas camadas superficiais mais permeáveis, seguidas de camadas de permeabilidades mais uniformes. 


\section{7 \\ Análises Numéricas}

7.1

\section{Perfil do terreno}

O perfil do terreno foi obtido a partir das sondagens mencionadas no item 3.6, com furos localizados conforme a Figura 6.1:

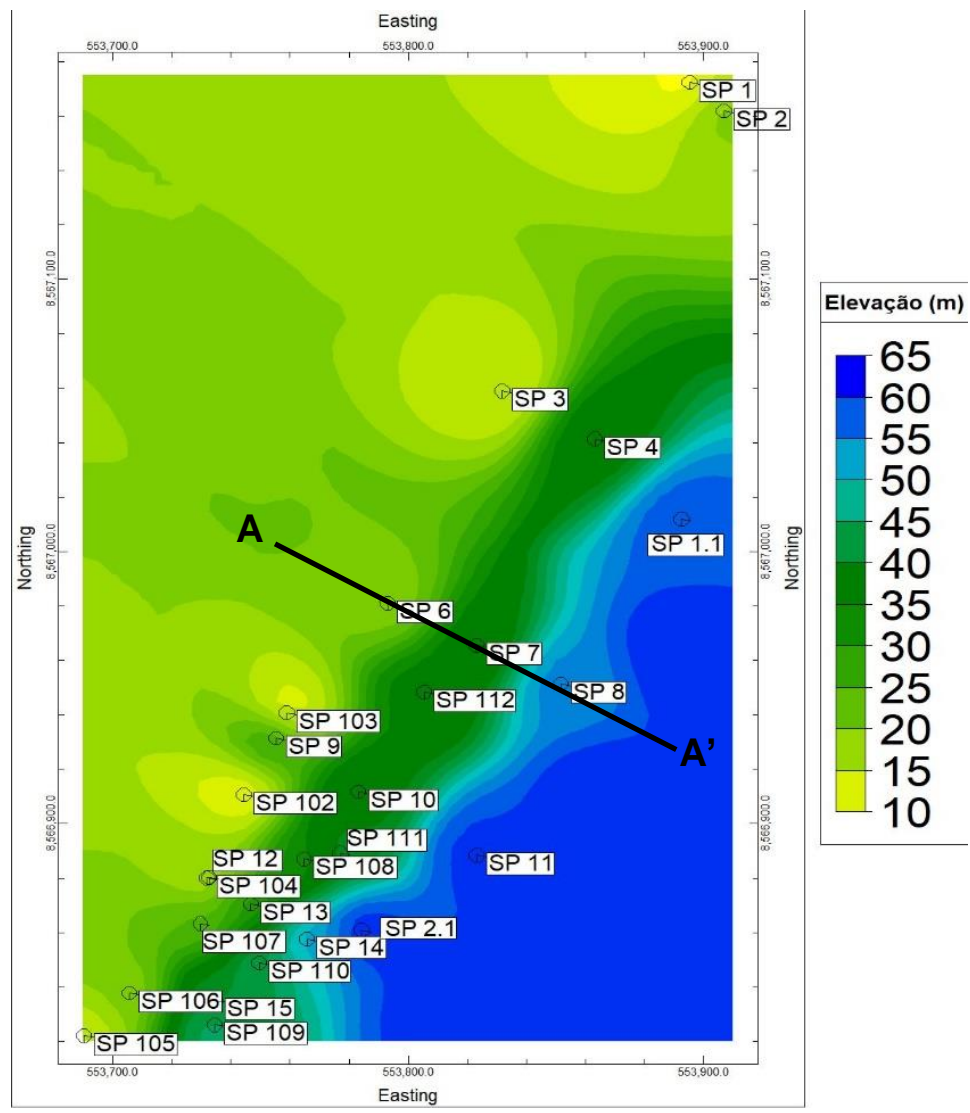

Figura 7.1 - Locação dos furos de sondagem

A partir da interpolação dos pontos das curvas de nível situados à esquerda e à direita do local do deslizamento, chegou-se à topografia aproximada anterior a este, ocorrido na seção formada pelos furos SP-06, SP-07 e SP-08, exibidos no anexo I. O perfil transversal encontrado está exposto na Figura 6.2, na qual a linha tipo cerca indica a topografia antiga e a linha cheia a topografia atual.

A estratigrafia do terreno foi determinada a partir dos furos de sondagem mencionados e dos e dos resultados dos ensaios de caracterização das amostras 
coletadas, chegando-se à seguinte divisão de camadas, ilustrada na Figura 6.2. Foram aplicados os parâmetros das amostras mais próximas do local da ruptura, especificadas adiante.

1) Aterro / colúvio;

2) Solo residual maduro;

3) Solo residual jovem.

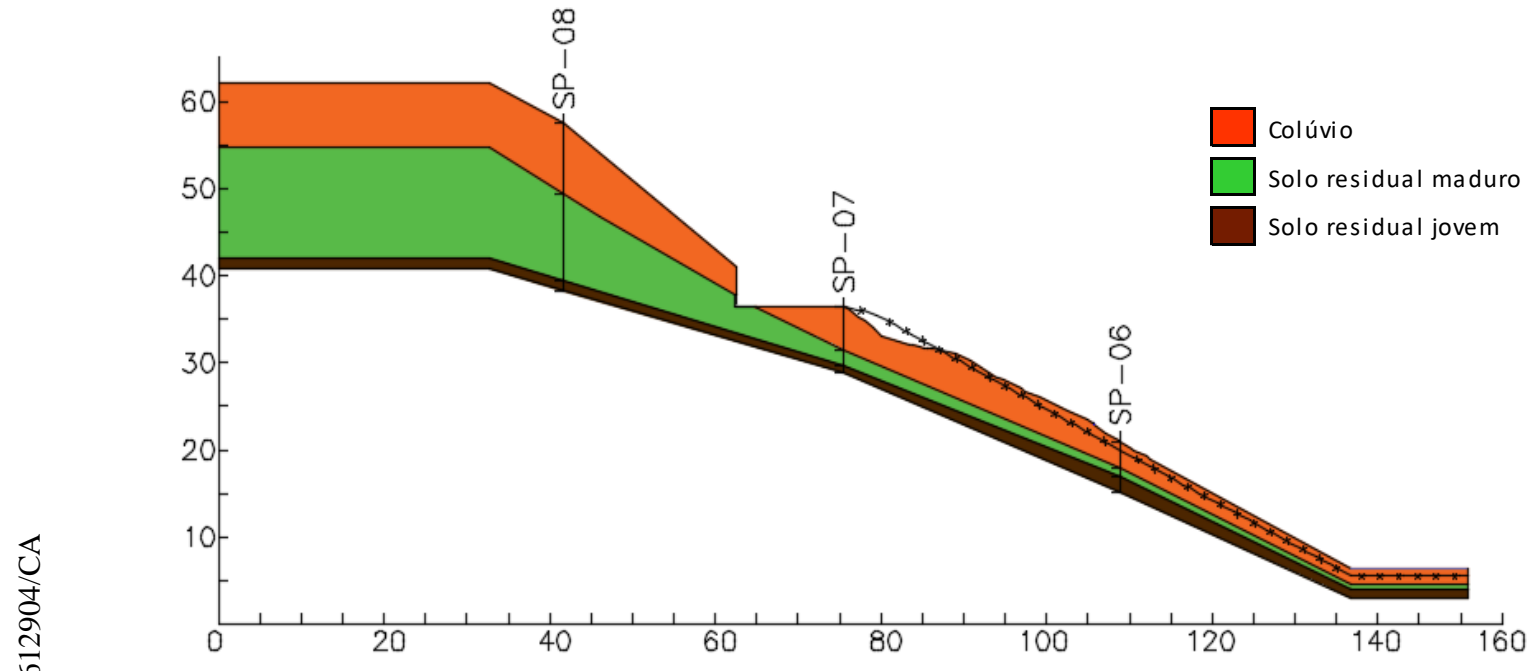

Figura 7.2 - Seção transversal do local antes e após o deslizamento

Com os dados topográficos e perfis de sondagem, foi possível traçar o perfil 3D do terreno no programa Rockworks 17, apresentado na Figura 7.3.

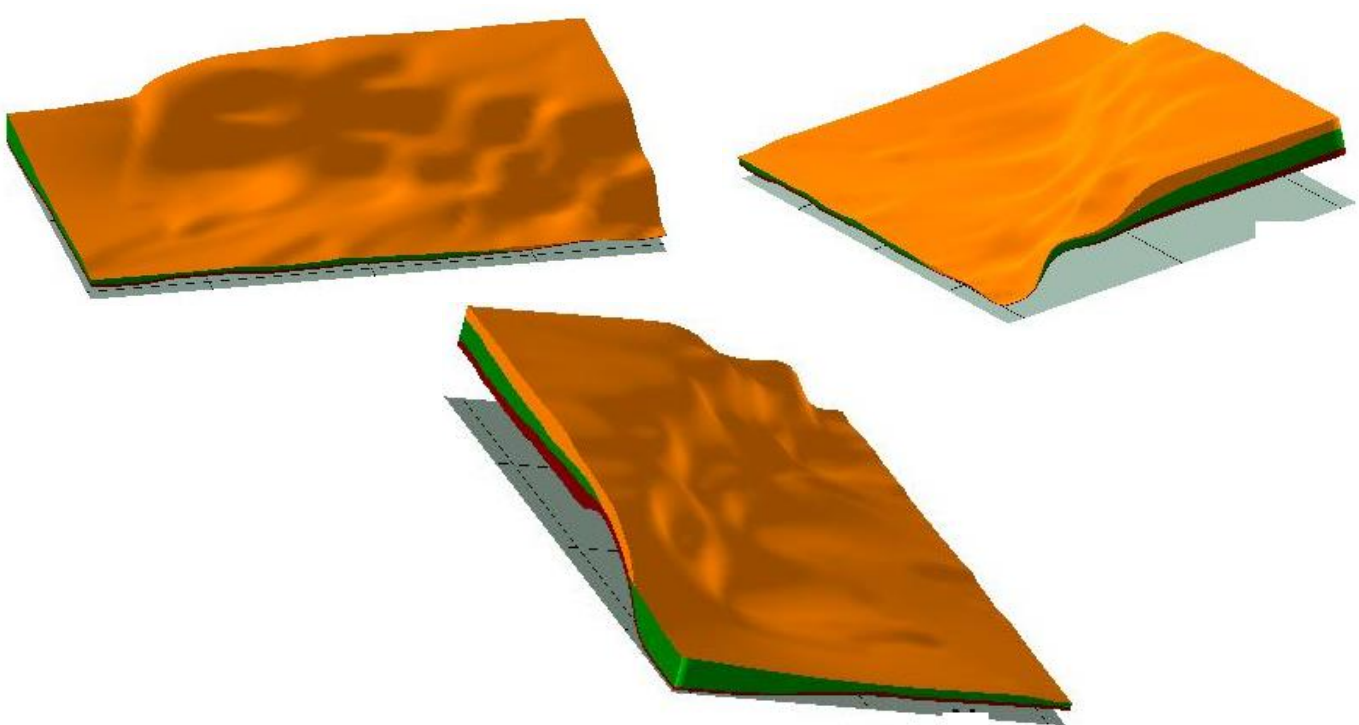

Figura 7.3 - Perfil 3D do talude estudado 


\section{2}

\section{Análise de infiltração}

Nesta etapa, simulou-se uma situação de fluxo em regime transiente, provocado pelas condições climáticas e águas servidas despejadas pela população no talude (item 7.2.3), através do programa Seep/w (GeoStudio, 2018).

Foram estudados 4 casos, com e sem a aplicação das águas servidas e com as permeabilidades saturadas de laboratório e campo, organizados na Tabela 7.1:

Tabela 7.1 - Casos estudados nas análises de infiltração

\begin{tabular}{c|c}
\hline Caso & Descrição \\
\hline 1 & Permeabilidade laboratório, sem águas servidas \\
\hline 2 & Permeabilidade laboratório, com águas servidas \\
\hline 3 & Permeabilidade campo, sem águas servidas \\
\hline 4 & Permeabilidade campo, com águas servidas \\
\hline
\end{tabular}

Não se dispôs de dados de sondagem e umidade do solo na época da ruptura, não sendo possível conhecer a posição do nível d'água e as poropressões no talude. Neste caso, foram adotadas as umidades de coleta das amostras (realizada no mês de março), assumindo-se que, para a mesma época do ano de 2011, as umidades no local seriam as mesmas. Assim, a análise foi executada para o período de março até o dia da ruptura, totalizando 254 dias. Os valores de sucção inicial encontrados são especificados no item 7.2.2.

\subsection{1}

\section{Descrição da malha}

O programa utiliza o método numérico dos elementos finitos, no qual o maciço é subdividido em pequenos pedaços, estudando-se o comportamento de cada um individualmente, para serem em seguida reconectados, representando 0 talude como um todo (GeoStudio, 2018).

Foi então aplicada uma malha composta por quadrados e triângulos de 0,5m de lado, cada elemento com quatro ou três nós, respectivamente, conforme ilustra a Figura 7.4. Tal configuração se mostrou satisfatória, não tendo sido acusado pelo programa problemas de convergência nos resultados. 


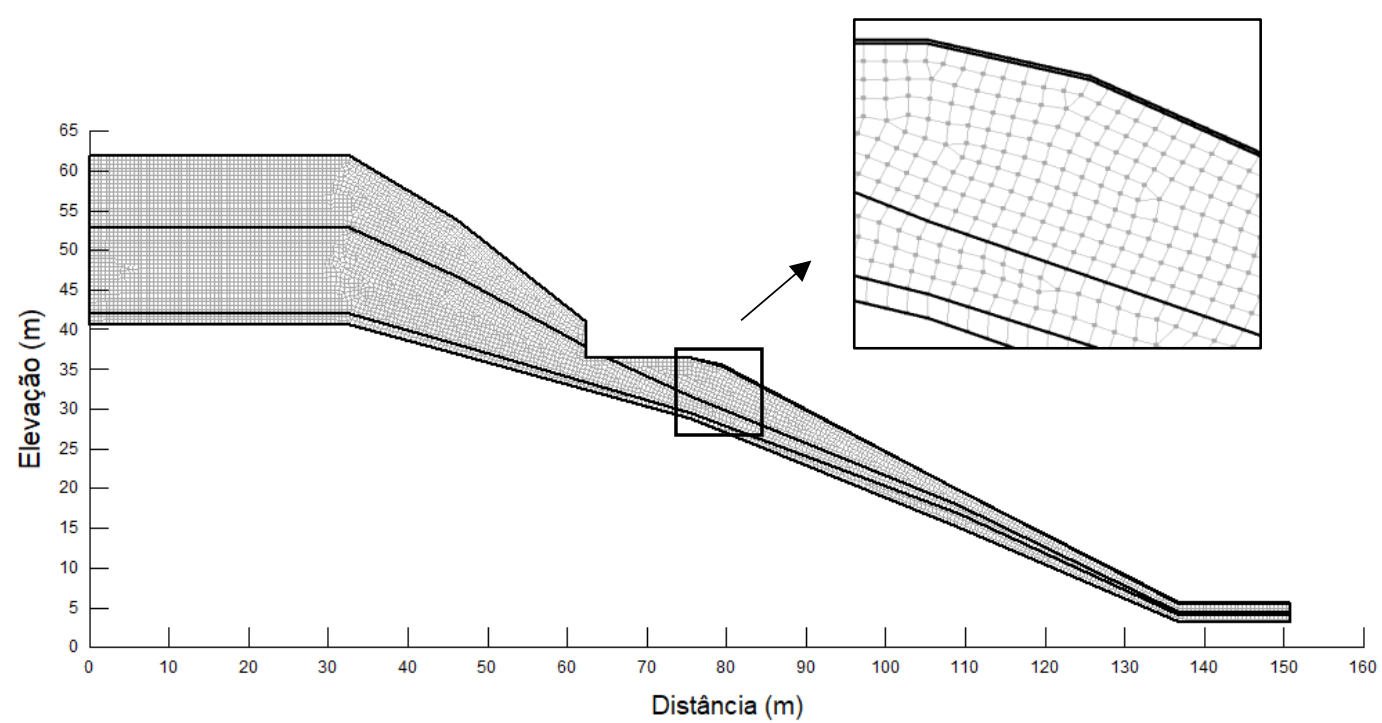

Figura 7.4 - Malha aplicada nas análises

\subsection{2}

\section{Parâmetros hidráulicos}

Conforme já mencionado, na camada do colúvio, foi encontrada uma maior permeabilidade nos ensaios de campo realizados para $0,6 \mathrm{~m}$ de profundidade. No laboratório, a AM 2 apresentou maior permeabilidade e curva característica bimodal, enquanto na AM 4, coletada em maior profundidade que a anterior, observouse uma permeabilidade com menor ordem de grandeza e curva característica unimodal. É importante a representação deste cenário, pois a presença de uma camada de permeabilidade mais alta que as precipitações diárias resulta na ausência de runoff no talude.

Assim, o colúvio foi dividido em duas partes para as análises de infiltração: a primeira com $0,80 \mathrm{~m}$ (média entre 0,6 e 1) e o restante até o contato com a camada subjacente.

Os parâmetros hidráulicos aplicados, obtidos através do programa experimental, estão resumidos na Tabela 7.2.

Ressalta-se que os parâmetros do solo residual jovem foram estimados, tendo sido aplicada a este a curva característica da camada superior, admitindose que esta é menos permeável e a umidade aumenta com a profundidade, reduzindo a sucção. Foram testados outros valores de sucção inicial, que não provocaram alterações nos resultados. 
Tabela 7.2 - Parâmetros hidráulicos do perfil estudado

\begin{tabular}{c|c|c|c|c|c}
\hline Camada & AM & $\boldsymbol{\theta}_{\text {coleta }}(\%)$ & $\boldsymbol{\psi}_{\boldsymbol{i}}(\mathbf{k P a})$ & $\boldsymbol{k}_{\text {sat, } \text { campo }}(\mathrm{cm} / \mathbf{s})$ & $\boldsymbol{k}_{\text {sat, lab }}(\mathrm{cm} / \mathbf{s})$ \\
\hline Colúvio 1 & 2 & 28,7 & 1500 & $1,55 \mathrm{E}-02$ & $1,51 \mathrm{E}-04$ \\
\hline Colúvio 2 & 4 & 32,1 & 2000 & $4,09 \mathrm{E}-03$ & $6,45 \mathrm{E}-05$ \\
\hline SRM & 5 & 29,5 & 1700 & $1,39 \mathrm{E}-03$ & $4,58 \mathrm{E}-05$ \\
\hline SRJ & - & - & 1400 & \multicolumn{4}{|c}{$1,00 \mathrm{E}-05$} \\
\hline
\end{tabular}

As curvas de permeabilidade não saturada dos materiais, apresentadas nas Figuras 7.5 e 7.6, foram obtidas pelo método de Fredlund e Xing (1994) no próprio programa.

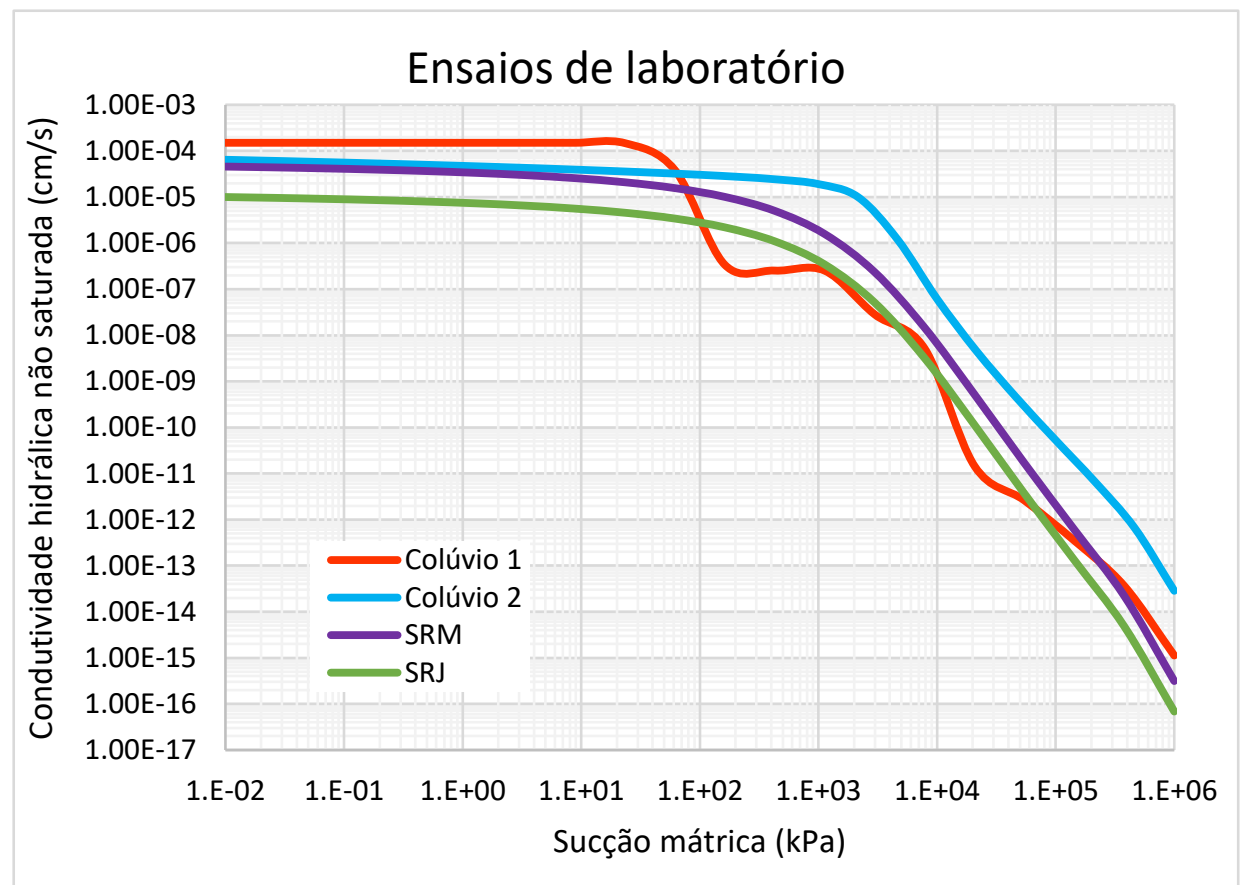

Figura 7.5 - Condutividades hidráulicas não saturadas para as permeabilidades saturadas encontradas em laboratório 


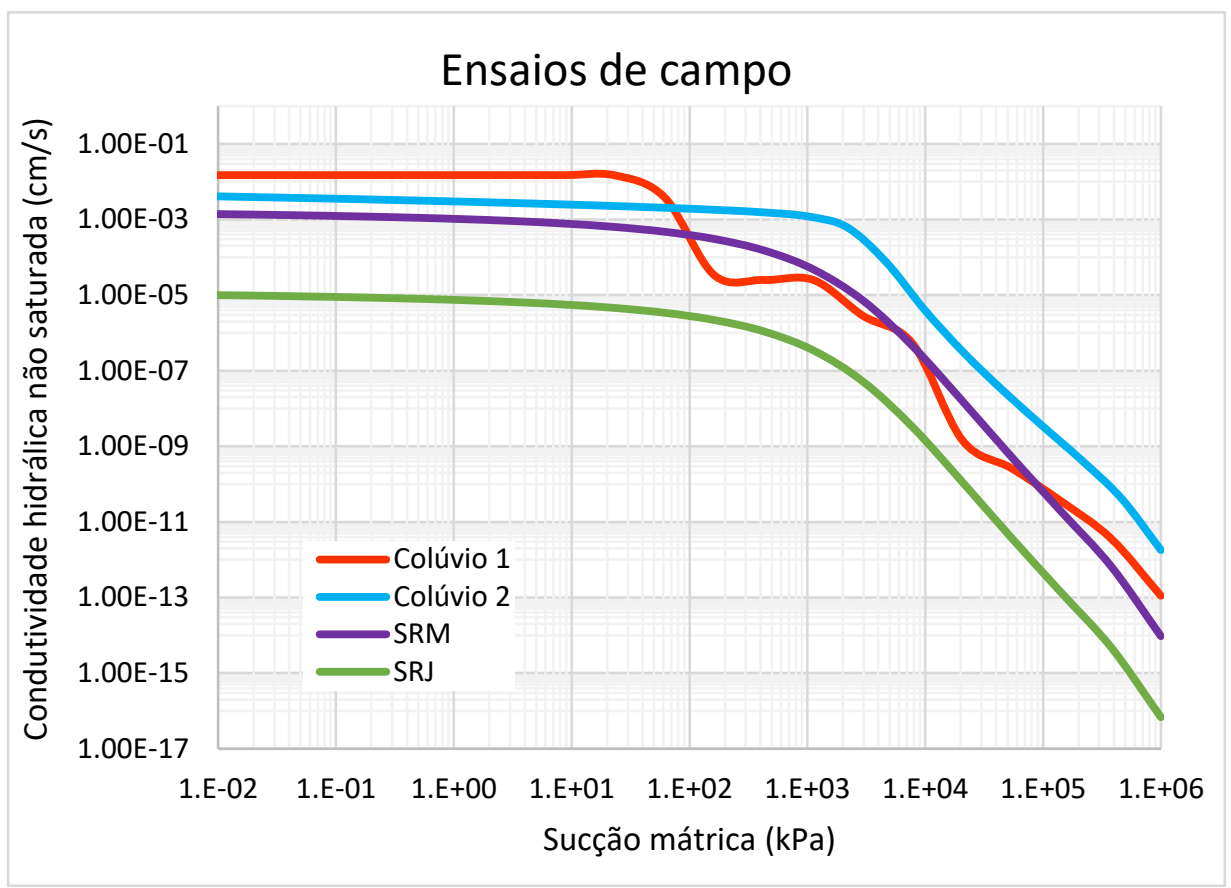

Figura 7.6 - Condutividades hidráulicas não saturadas para as permeabilidades saturadas encontradas em campo

\subsection{3}

Dados climáticos

Para as análises, o programa requeriu, além dos dados diários de precipitação e evapotranspiração, os dados de temperatura média e umidade relativa do ar, sendo possível simular a interação do solo com as condições impostas pelo clima.

Os dados climáticos diários, exibidos nas Figuras 7.7 a 7.10, foram coletados na platafotma do INMET, da estação Ondina, localizada a cerca de 4,5 km da área de estudo. 


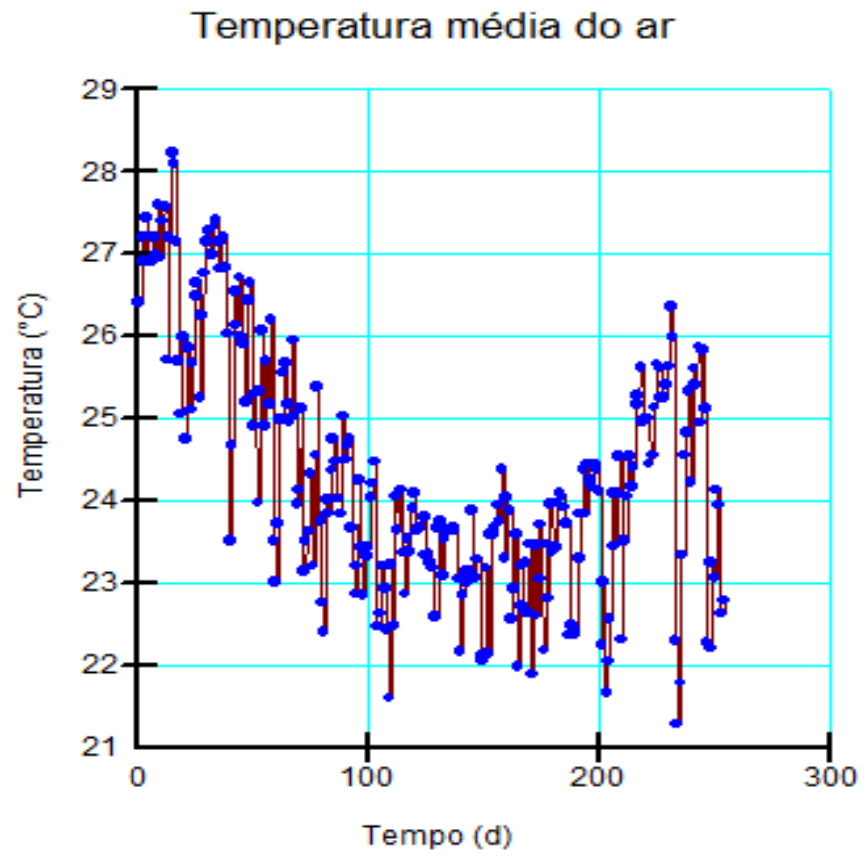

Figura 7.7 - Dados diários de temperatura média do ar (INMET)

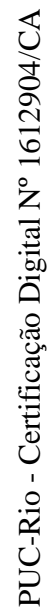

Umidade relativa do ar

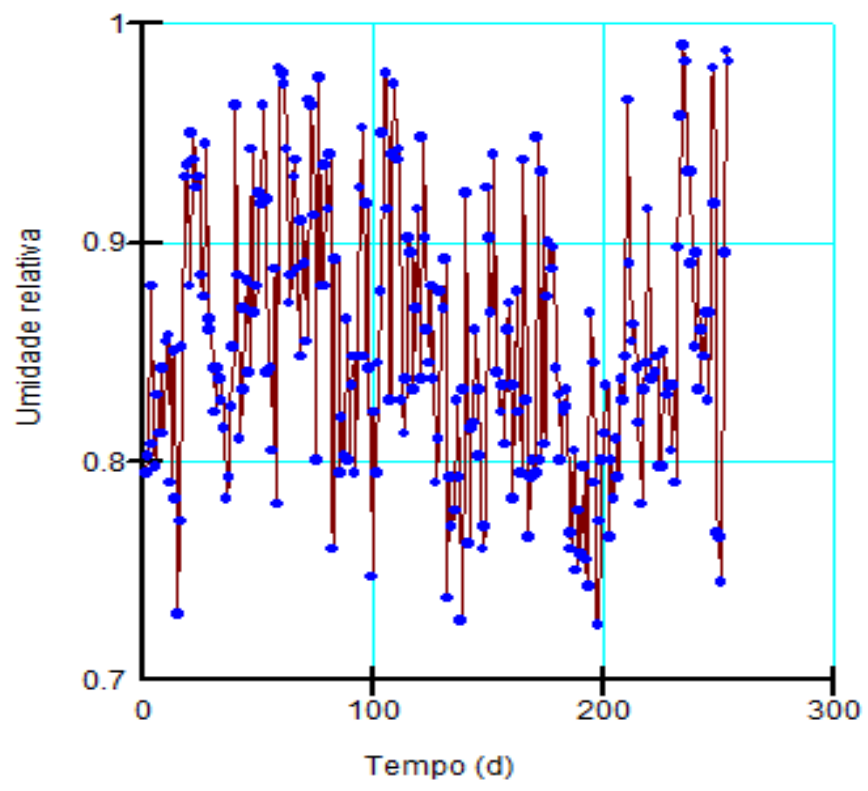

Figura 7.8 - Dados diários de umidade relativa (INMET) 


\section{Evapotranspiração potencial}

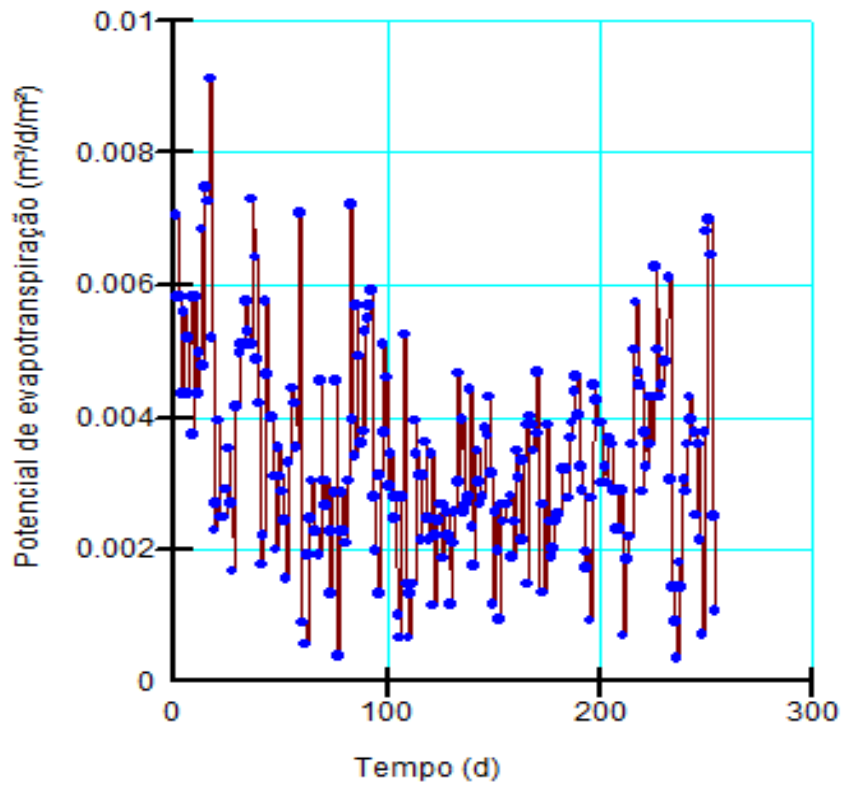

Figura 7.9 - Dados diários de evapotranspiração potencial (INMET)

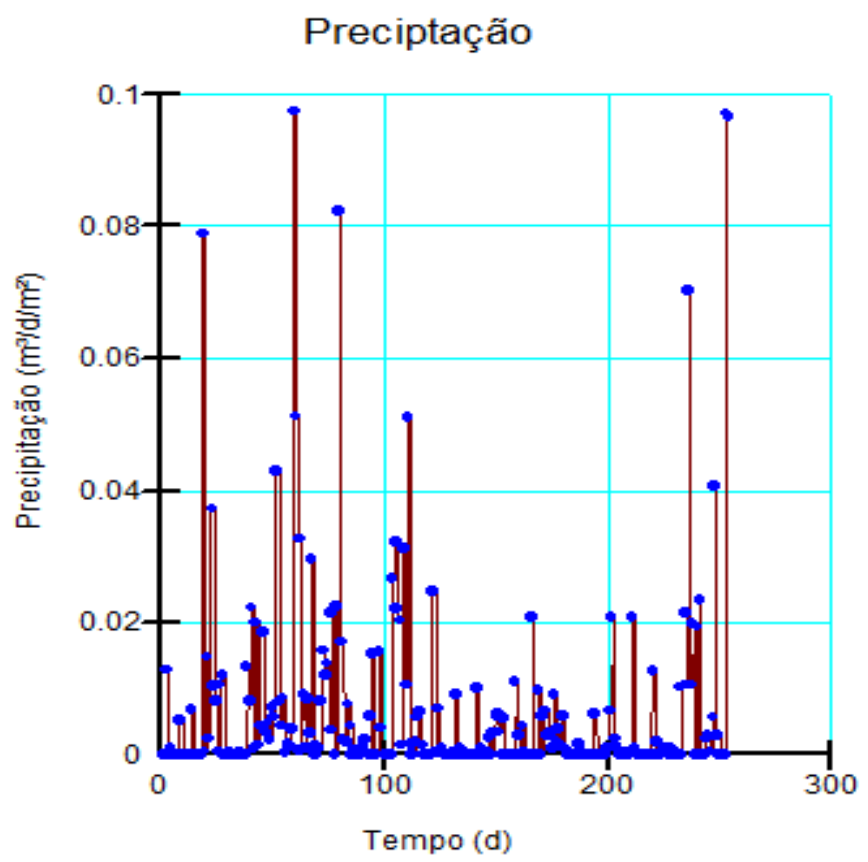

Figura 7.10 - Dados diários de preciptação (INMET)

Para as águas servidas, foi utilizada a proposta de Assunção (2005), que quantificou, para uma comunidade típica de Salvador, uma vazão de 3,43 mm/dia para cada metro quadrado de residência, ou seja, uma precipitação diária equivalente. Para a condição de contorno que inclui a ação antrópica, este valor foi adicionado à precipitação diária, como mostra a Figura 7.11: 


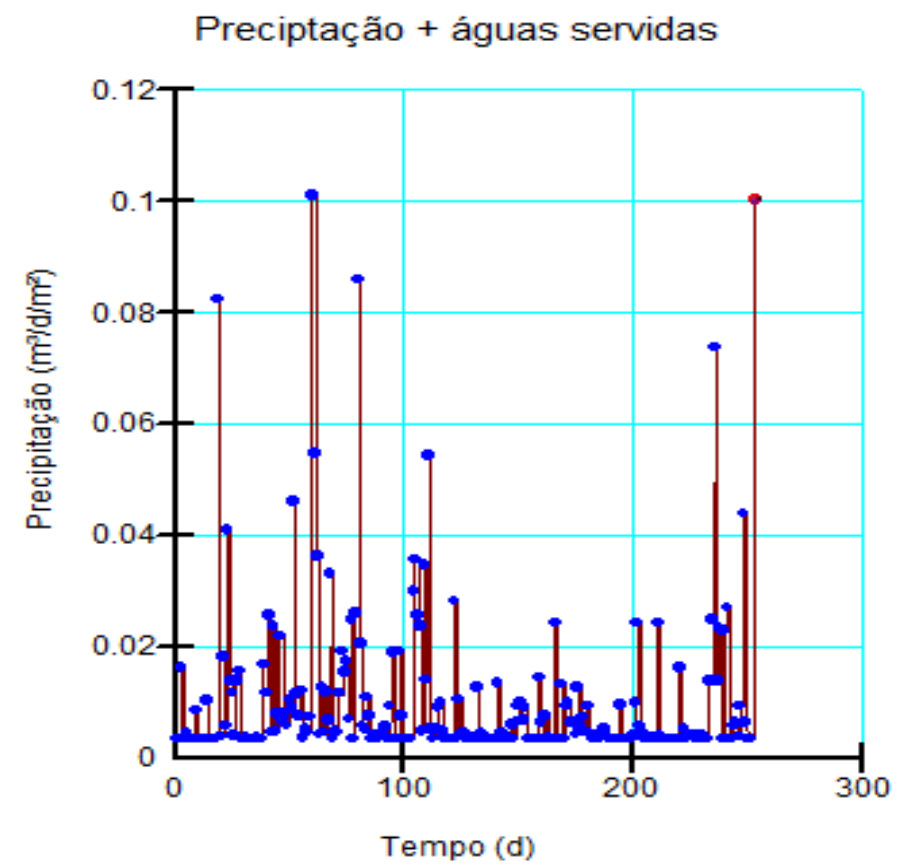

Figura 7.11 - Dados diários de precipitação somados com a ação antrópica

\subsection{4 \\ Condições de contorno e perfil de poropressões inicial}

As condições de contorno estudadas, bem como o perfil de poropressões inicial, estão apresentadas nas Figuras 7.12 e 7.13.

A ação antrópica só foi considerada nos locais em que havia edificações, sendo a interação Terra-clima representada pela cor roxa e a interação Terraclima + águas servidas pela cor vermelha.

$\mathrm{Na}$ crista do talude, foi identificada uma calçada cimentada, tornando o local impermeável, condição indicada pela cor verde. $\mathrm{O}$ contato solo-rocha foi tratado como uma face livre para percolação de água, visto que se trata de uma rocha altamente fraturada.

A linha azul representa o NA, localizado no contato solo-rocha. A mudança de posição deste não alterou os resultados.

O perfil de poropressões inicial foi estabelecido de acordo com os dados da Tabela 7.2, considerando que as sucções seriam uniformes em todas as camadas. 


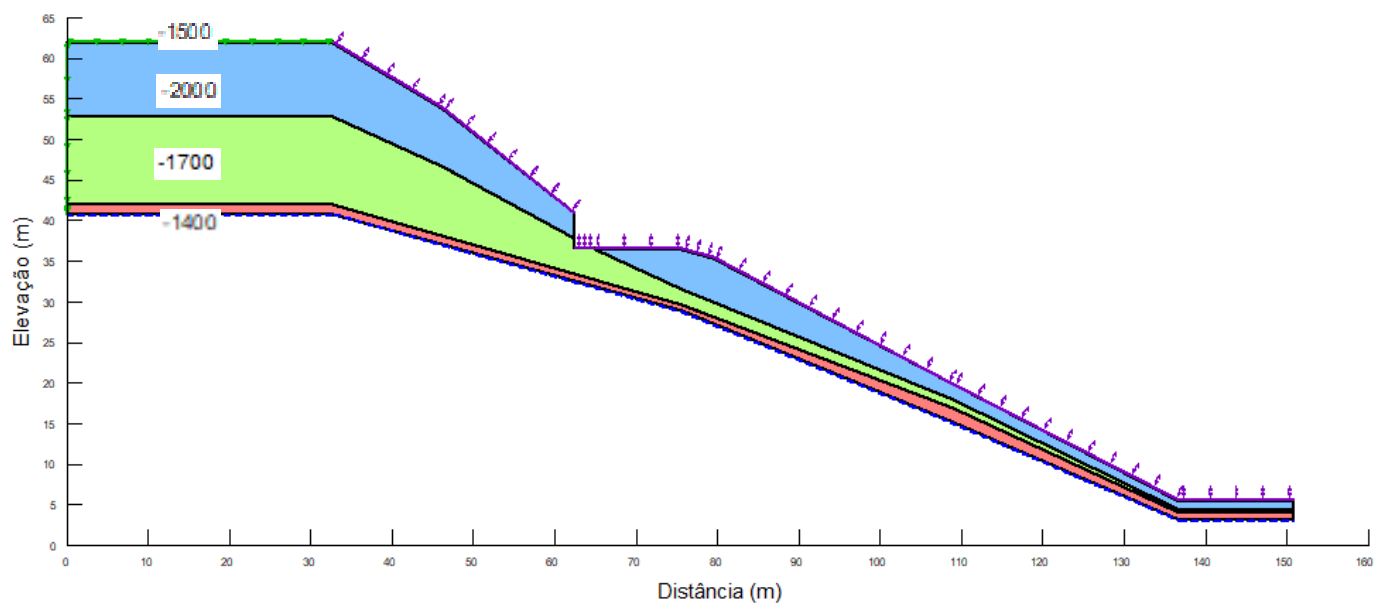

Figura 7.12 - Condições de contorno sem águas servidas

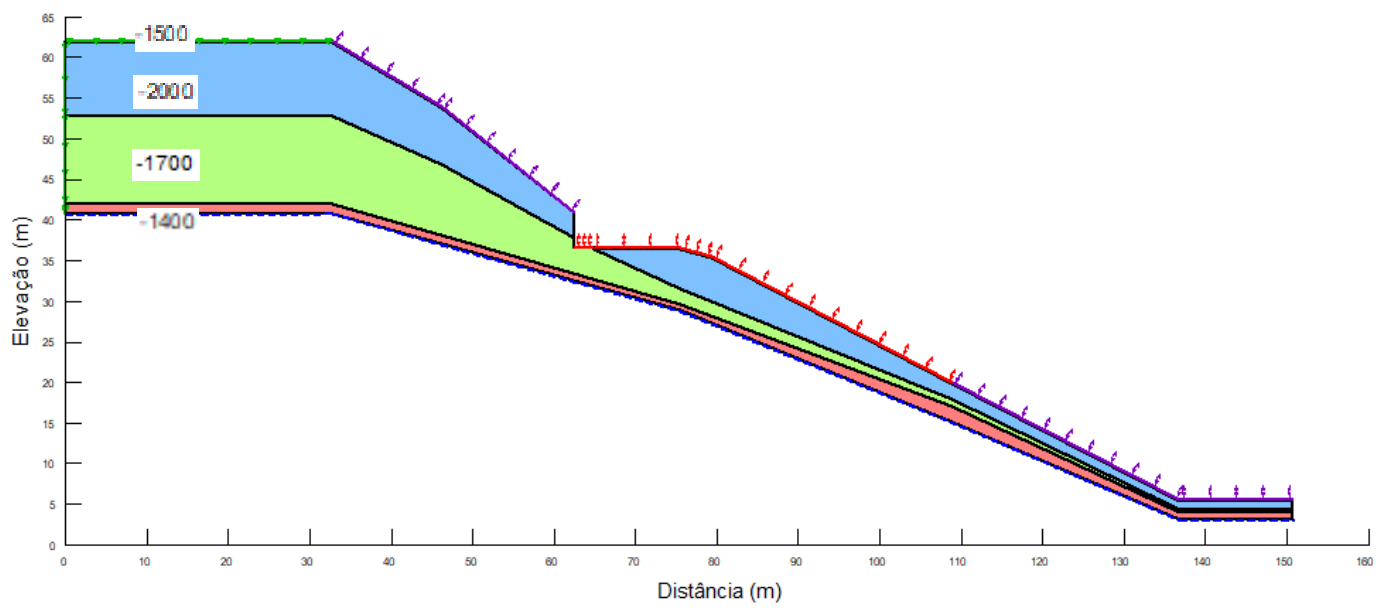

Figura 7.13 - Condições de contorno considerando águas servidas

\section{2 .5}

Resultados e discussões

\subsubsection{1}

Casos 1 e 2: Permeabilidades de laboratório

Nestes casos, foram aplicadas as menores permeabilidades, que resultaram em uma posição final do nível d'água que não correspondeu com o ocorrido em campo, já que não foi vista a presença de água na cicatriz da ruptura.

Os perfis de poropressões obtidos ao final das análises estão representados nas Figuras 7.14 e 7.15, nas quais cada linha representa uma diferença de poropressão de $10 \mathrm{kPa}$. 


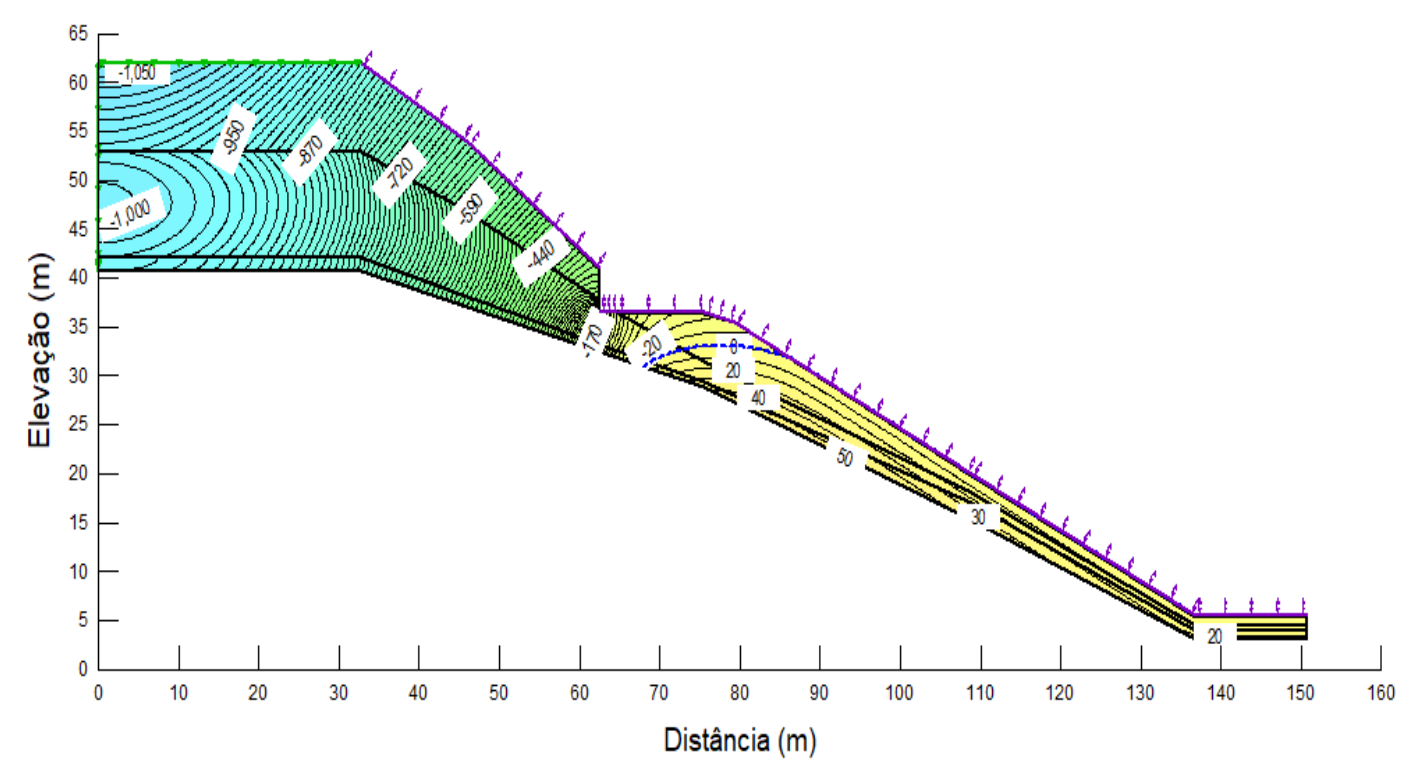

Figura 7.14 - Perfil de poropressões para o caso 1 após 254 dias

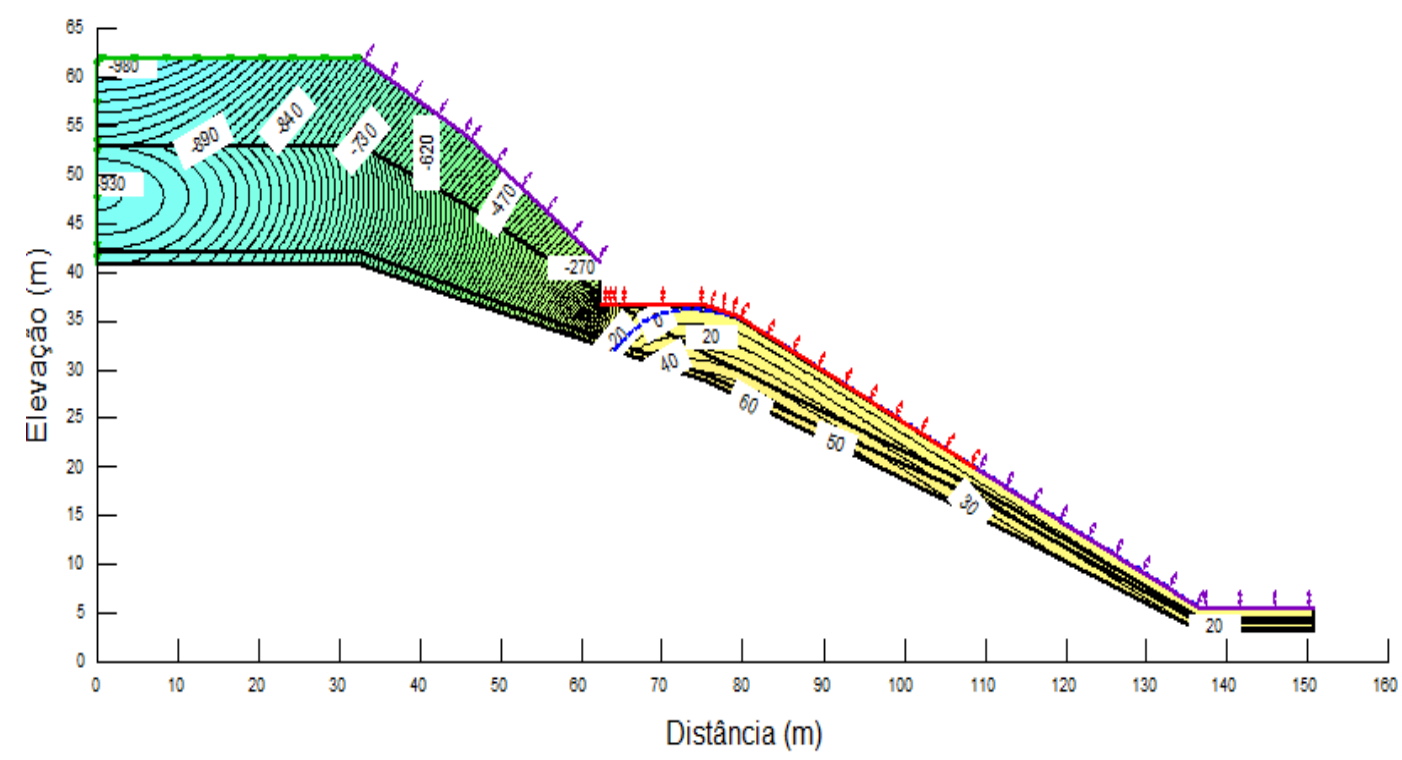

Figura 7.15 - Perfil de poropressões para o caso 2 após 254 dias

\subsubsection{2}

\section{Casos 3 e 4: Permeabilidades de campo}

As Figuras 7.16 e 7.17 mostram os perfis de poropressão encontrados nas análises. Estes casos mostraram uma posição final mais coerente do nível d'água, provocado pela ação combinada da chuva e água lançada pela população, tendo sido estes os aplicados nas análises de estabilidade. Apesar de terem ocorrido chuvas intensas outras vezes durante o ano, como pode ser visto na Figura 7.10, 
a maioria ocorreu em apenas um dia, o que não seria suficiente para provocar a elevação do NA aqui encontrada.

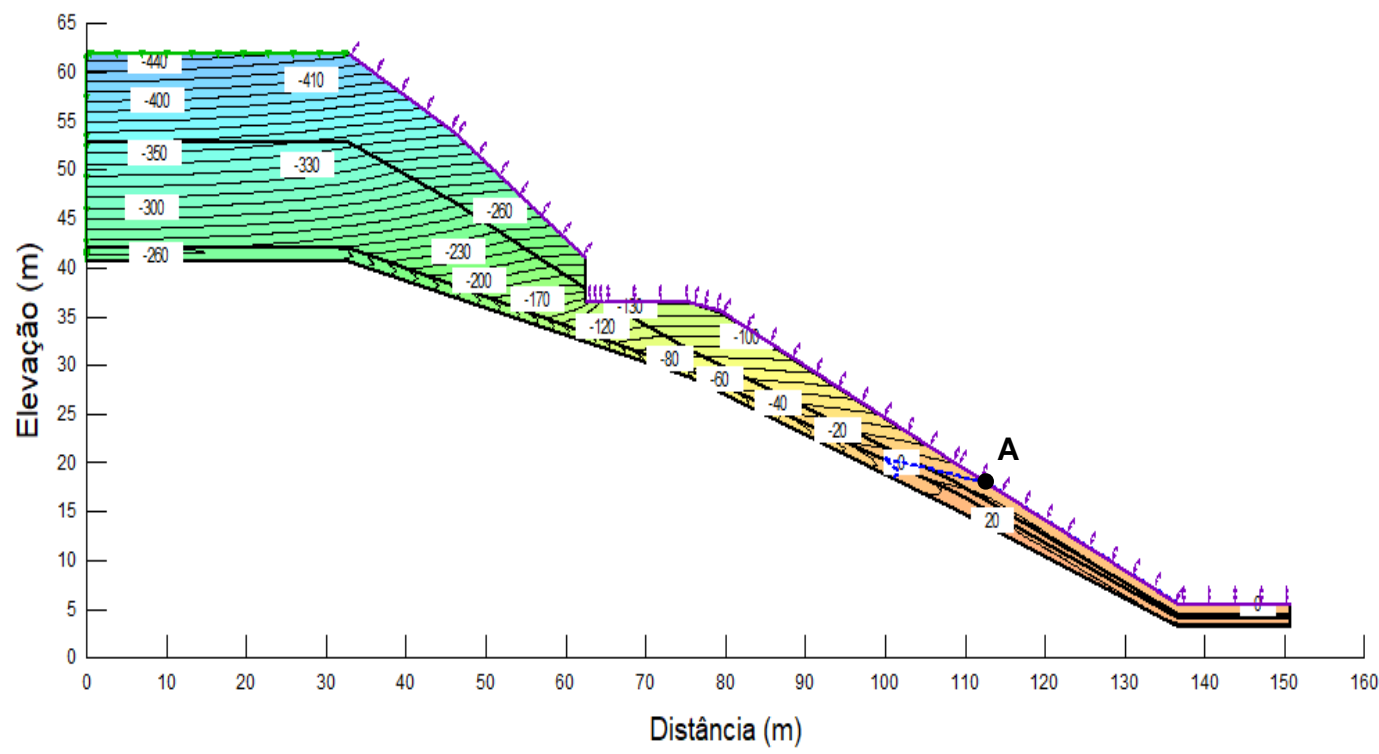

Figura 7.16 - Perfil de poropressões para o caso 3 após 254 dias

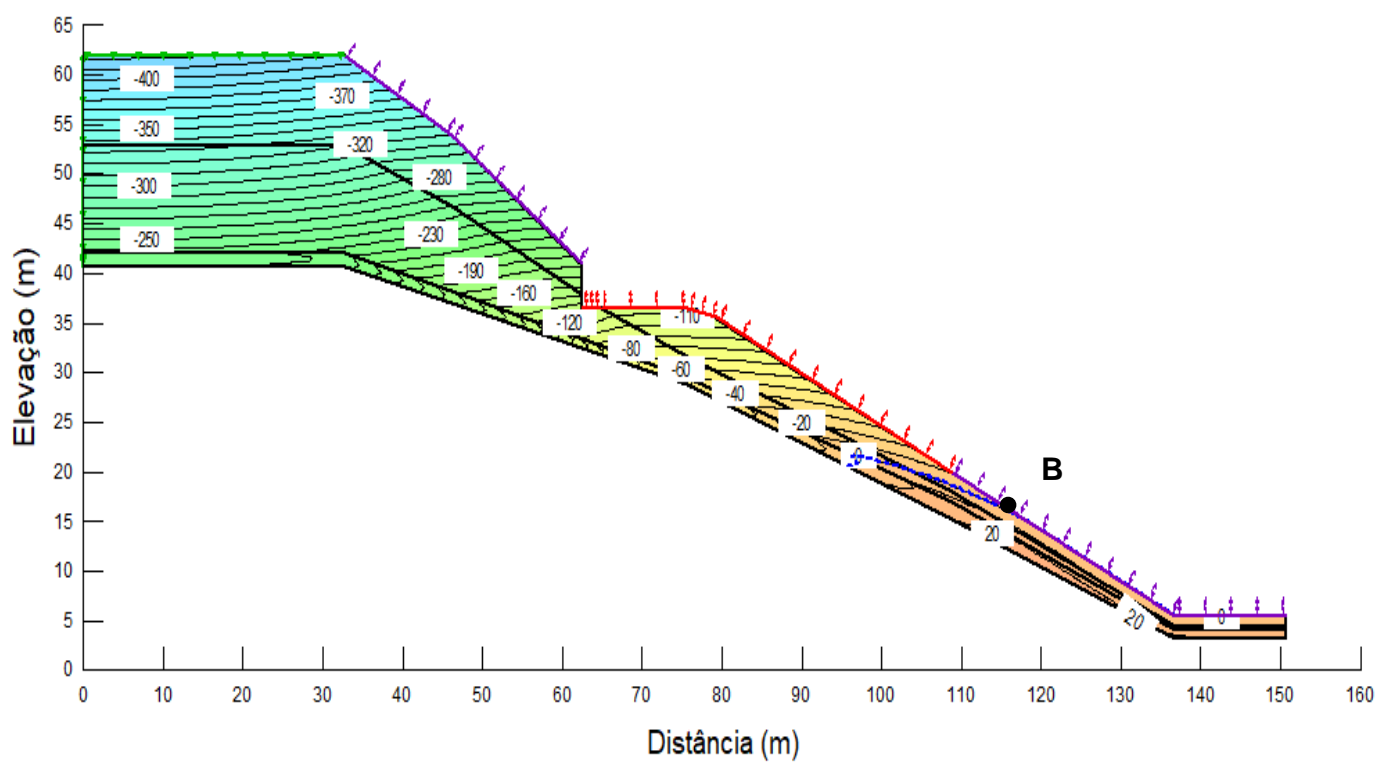

Figura 7.17 - Perfil de poropressões para o caso 4 após 254 dias

Pelas curvas de poropressão em função do tempo, vê-se que as altas sucções iniciais, que chegariam aos seus maiores valores no fim do período de seca, são dissipadas no período chuvoso. A partir do dia 122 (final do mês de junho), observa-se que as poropressões se mantém aproximadamente constantes, até o último dia da análise, quando chove quase $100 \mathrm{~mm}$ pelo segundo dia consecutivo, 
o que impede a drenagem na camada menos permeável, provocando o surgimento de um nível d'água.

As curvas estão apresentadas na Figura 7.18, para os pontos A e B, indicados nas Figuras 7.15 e 7.16 .

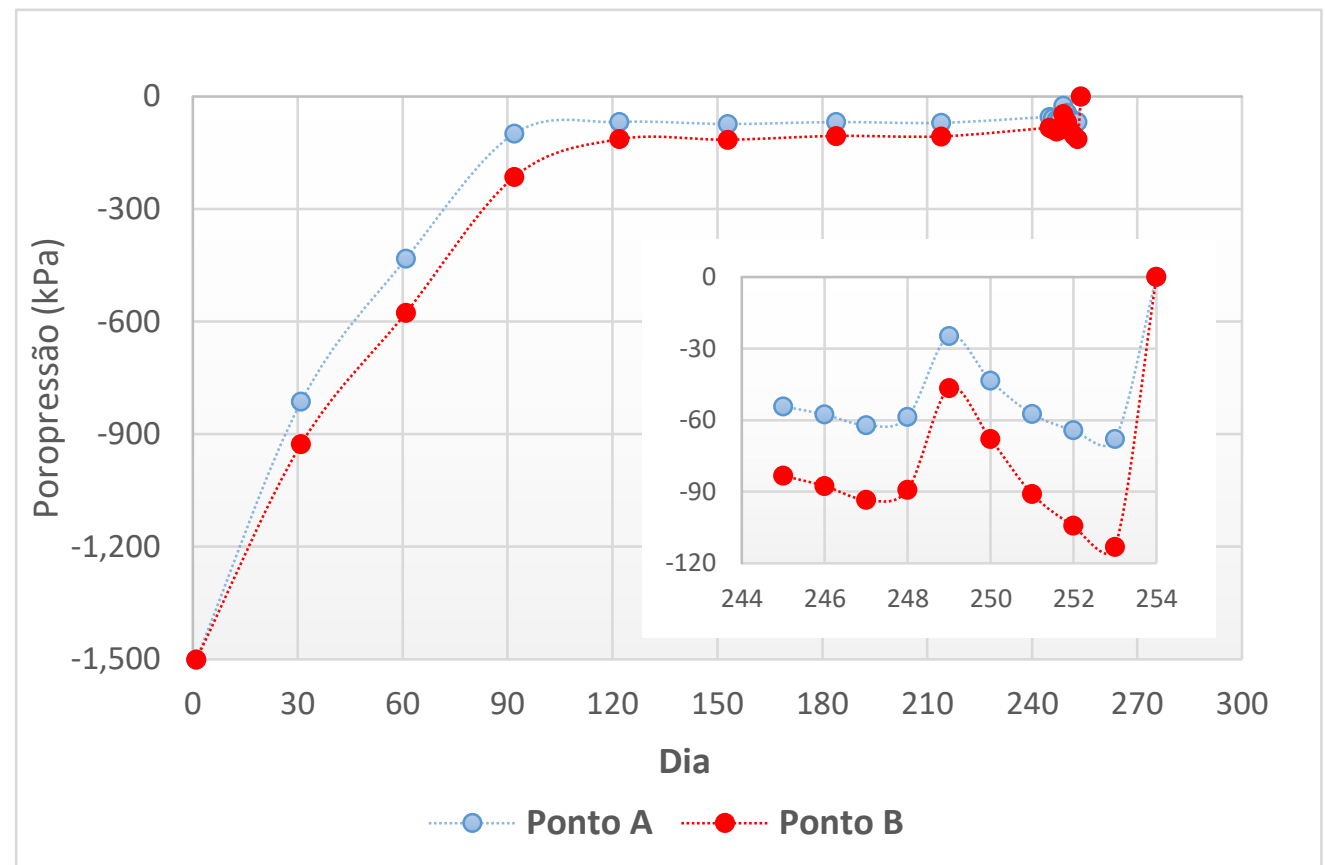

Figura 7.18 - Evolução da poropressão com o tempo para os pontos A e B

Comparando-se as curvas obtidas para os casos 3 e 4, percebe-se que as poropressões evoluem de maneiras semelhantes, sendo o diferencial entre estas as águas servidas, que ocasionam a maior redução na sucção para o caso 4 .

\section{3}

\section{Análise de estabilidade}

As análises de estabilidade foram realizadas com auxílio do programa Slope/w (GeoStudio, 2017), pelo método de Morgenstern e Price (1965), como mencionado anteriormente. A superfície de ruptura crítica foi encontrada pelo critério de "grades e raios", no qual uma ampla variação de superfícies de deslizamento de teste pode ser especificada com uma grade definida de centros de círculos e uma faixa de raios definidos (GeoStudio, 2017).

A Figura 7.19 ilustra as condições iniciais aplicadas. A ação antrópica foi considerada através de carregamentos uniformes verticais na superfície, representando as edificações construídas pela comunidade e a rua no topo talude com valores de, respectivamente, $14 \mathrm{kN} / \mathrm{m}^{2}$ e $10 \mathrm{kN} / \mathrm{m}^{2}$. 
Foram realizadas duas séries de análises, conforme a Tabela 7.3.

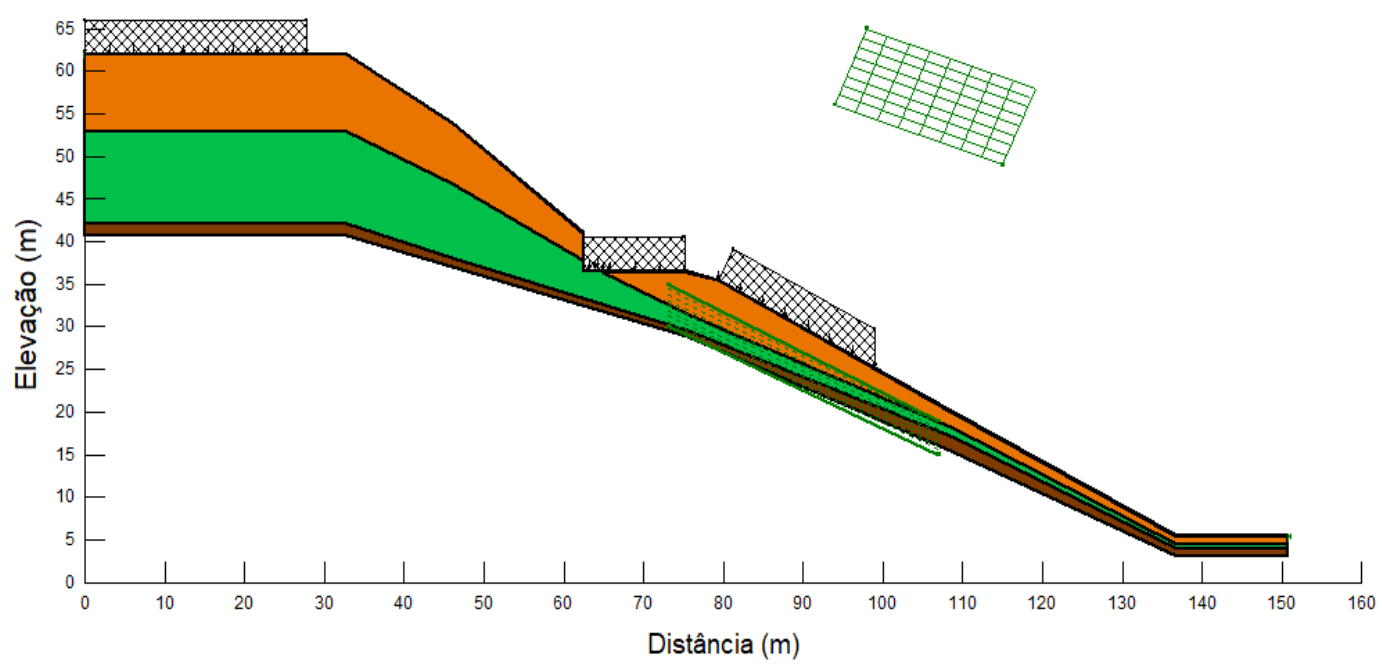

Figura 7.19 - Condições iniciais para as análises de estabilidade

Tabela 7.3 - Séries estudadas nas análises de estabilidade

\begin{tabular}{c|c}
\hline Série & Descrição \\
\hline 1 & Poropressões finais do caso 3 \\
\hline 2 & Poropressões finais do caso 4 \\
\hline
\end{tabular}

\subsection{1}

\section{Parâmetros de resistência}

Os parâmetros de resistência estão organizados na Tabela 7.4. Em termos de resistência, o colúvio foi considerado uma camada única, conforme observado nos resultados dos ensaios. O valor de $\phi^{b}$ foi adotado de acordo com a sucção média na provável superfície de ruptura, já que o programa não considera que seu valor é variável.

Devido à indisponibilidade de dados de resistência do solo residual jovem, seus dados foram adotados, com valores que não provocaram alterações nos resultados, sendo a hipótese de que a ruptura não atingiu esta camada considerada válida, já que o caso estudado aponta uma superfície de ruptura rasa. A curva da variação de $\phi^{b}$ com a sução (Figura 7.20) foi estimada assumindo-se que, para a condição seca, houve um aumento nos parâmetros da condição submersa na mesma proporção dos incrementos encontrados para as amostras ensaiadas. 


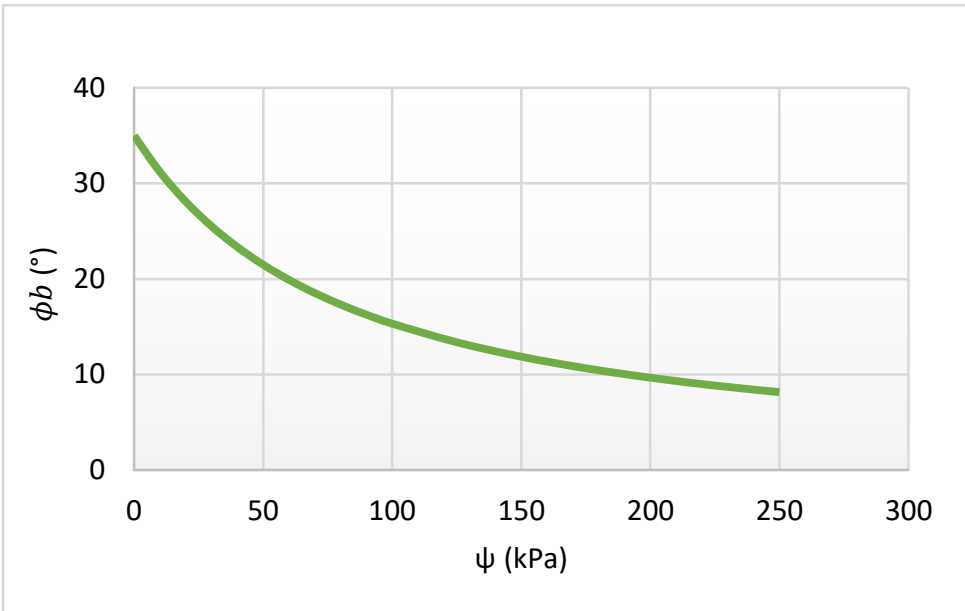

Figura 7.20 - Variação de $\phi^{b}$ com a sução para o solo residual jovem

Tabela 7.4 - Parâmetros de resistência do perfil estudado

\begin{tabular}{c|c|c|c}
\hline Camada & $\boldsymbol{c}^{\prime}(\mathbf{k P a})$ & $\boldsymbol{\phi}^{\prime}\left(^{\circ}\right)$ & $\boldsymbol{\phi}^{\boldsymbol{b}}\left(^{\circ}\right)$ \\
\hline Colúvio & 0 & 23,60 & 18,64 \\
\hline SRM & 0 & 24,01 & 20,22 \\
\hline SRJ & 45 & 35 & 28 \\
\hline
\end{tabular}

\subsection{2}

\section{Resultados e discussões}

A série 1 apresentou fator de segurança de 1,182 (Figura 7.21), o que não configura uma ruptura. Já para a série 2 , foi obtido um fator de segurança de 0,989 (Figura 7.22), podendo então esta situação ser indicativa do ocorrido em 2011.

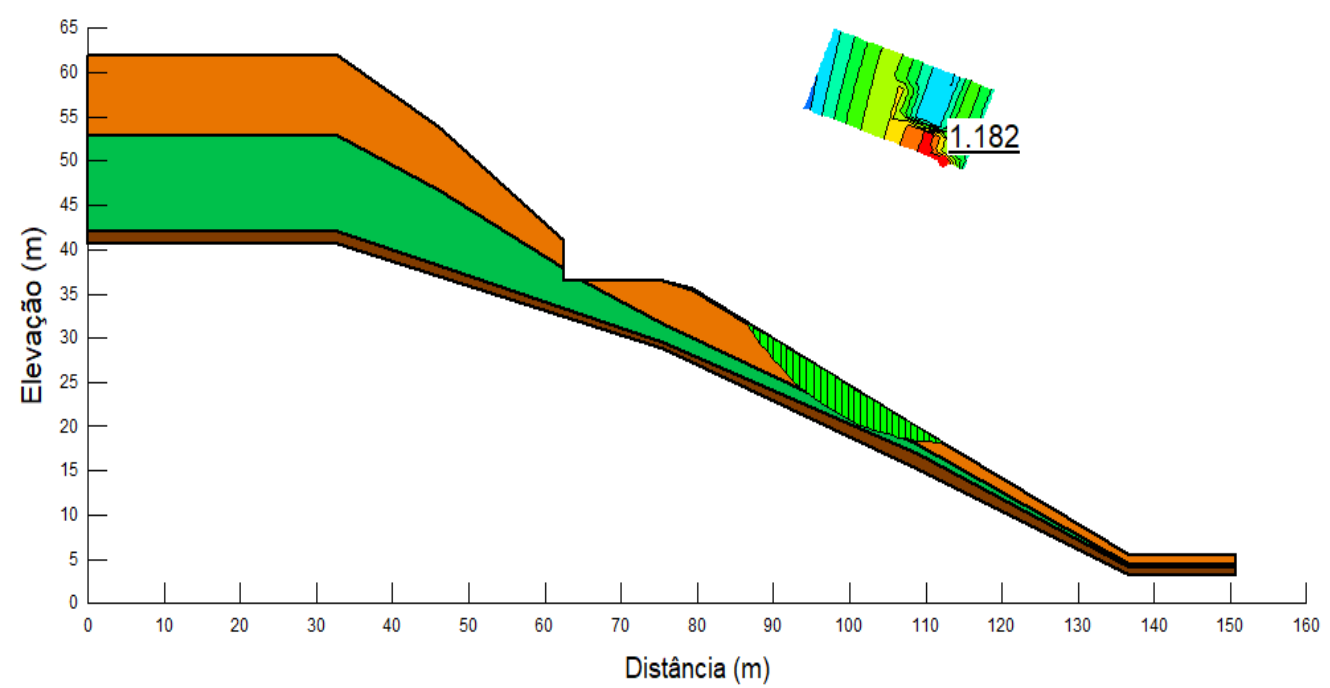

Figura 7.21 - Fator de segurança para a série 1 


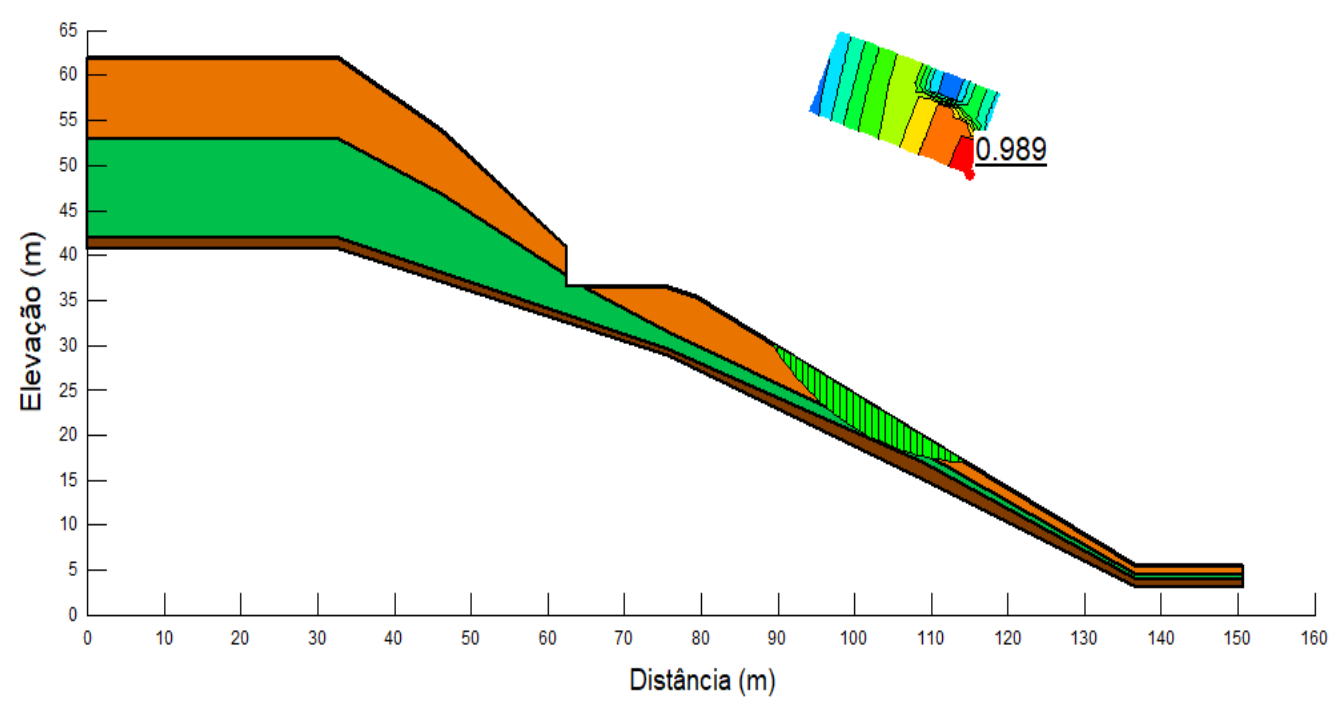

Figura 7.22 - Fator de segurança para a série 2

As análises mostram que o provável mecanismo de ruptura foi circular, com superfície rasa, na qual o material coluvionar e o solo residual maduro deslizaram sobre o solo residual jovem, o que concorda com o esperado no PDE (PMS, 2004).

Os resultados para as análises de estabilidade executadas com os perfis de poropressão encontrados pelas análises de infiltração sugerem que o mecanismo está associado à elevação de um nível d'água no terreno, o que pode ser ratificado pela curva FS x tempo da Figura 7.23. Pela queda brusca que houve em seu valor no último dia, verifica-se que seria necessária a presença de um NA (situação ocorrida neste último dia de análise) para que o talude perdesse sua estabilidade.

Pelas evoluções da precipitação, poropressão e FS com o tempo (Figura 7.23), percebe-se a sensibilidade do FS a variações na sucção, que por sua vez tem seus valores modificados de acordo com o índice de precipitação diária.

A queda do FS no dia 249 coincide com a chuva de aproximadamente $40 \mathrm{~mm}$ que ocorreu neste período, que provocou uma redução na sucção, como mostrado na curva de poropressão x tempo. Como esta chuva foi seguida por precipitações nulas (havendo apenas a ação das águas servidas nestes dias) ou próximas disto, a sucção, e por consequência o FS, voltou a crescer, até a chuva mais intensa, que desencadeou no evento aqui estudado. 

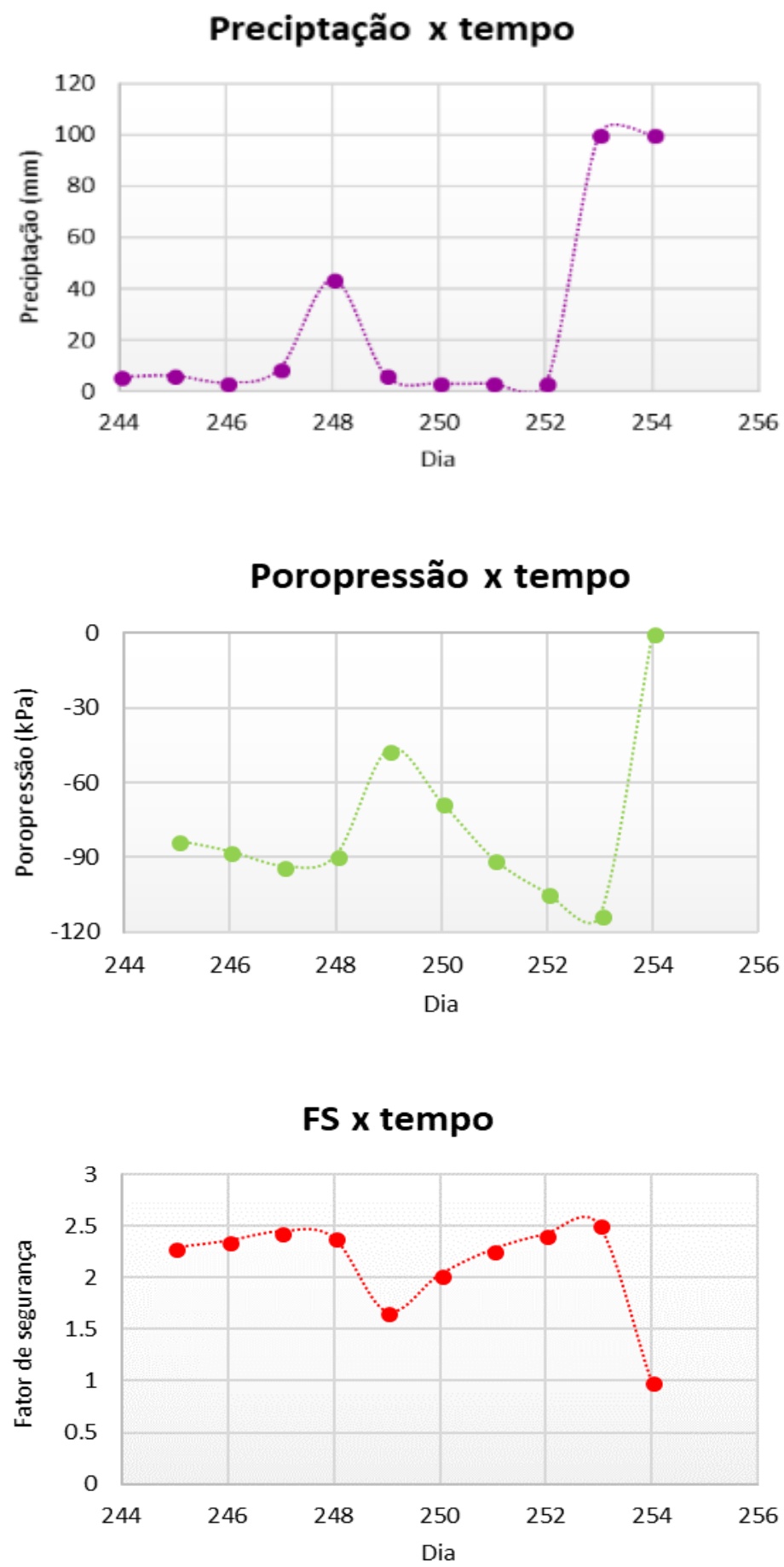

Figura 7.23 - Preciptação, poropressão e fator de segurança em função do tempo para os últimos 10 dias de análise

Através do menor fator de segurança encontrado para a série 2, em comparação com a série 1, pode ser observada a influência da interferência humana na estabilidade do talude, já que o fator de segurança tem seu valor aproximado para a unidade na situação em que as águas servidas são consideradas. 
Pela superfície de ruptura formada nas análises numéricas e pelo visto em campo e na cicatriz da ruptura pela topografia atual, percebe-se que o evento ocorrido tratou-se de uma ruptura retrogressiva, na qual os escorregamentos ocorrem talude acima, iniciada pelo escorregamento do material inferior. As Figuras 7.24 a 7.26 ilustram a sequência de deslizamentos ocorrida, após a primeira ruptura. Para estes casos, os valores de $\phi^{b}$ foram ajustados para as sucções no mesmo procedimento da primeira análise, assumindo-se que não houve alteração no perfil de sucção do talude.

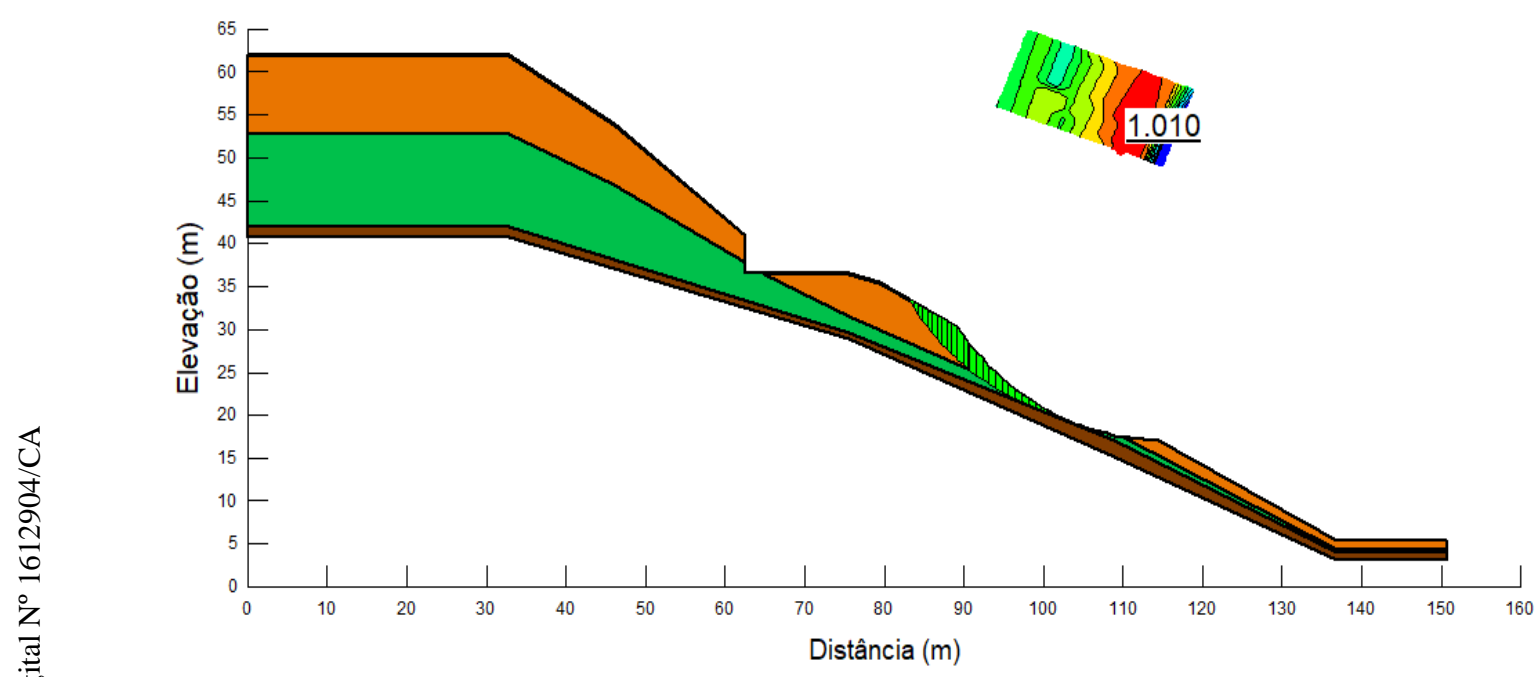

Figura 7.24 - Segundo deslizamento

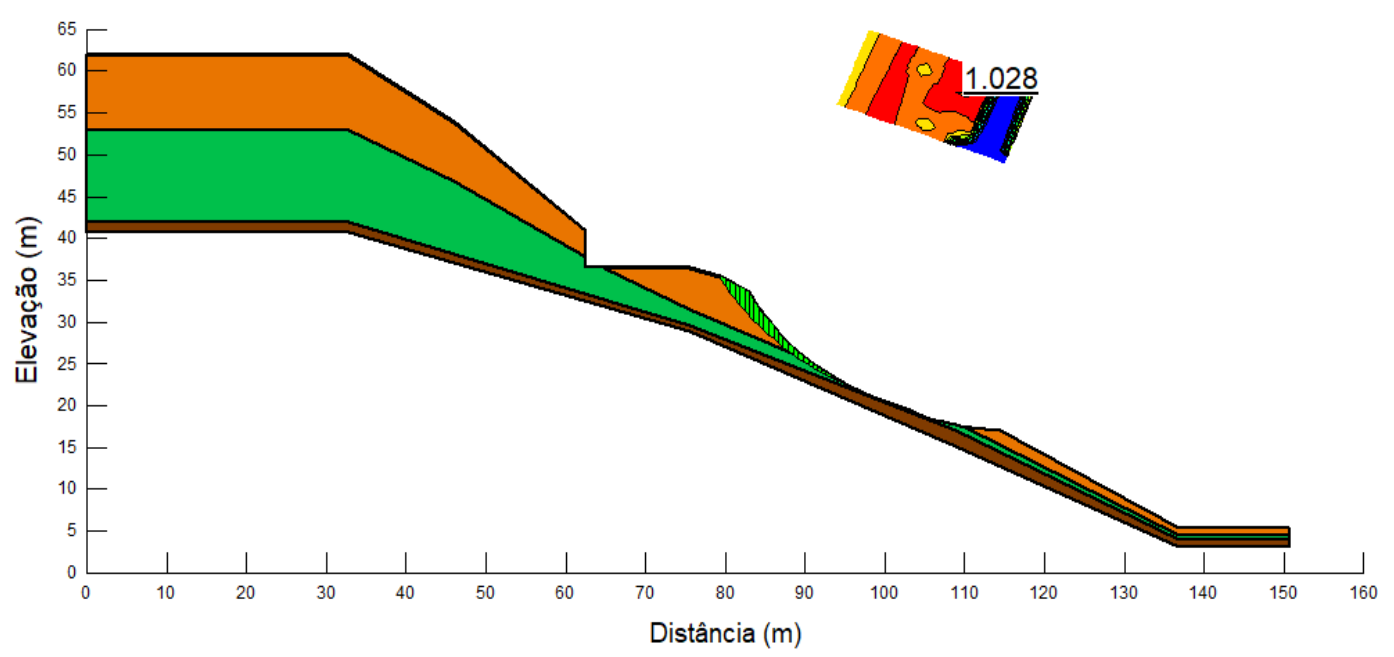

Figura 7.25 - Terceiro deslizamento 


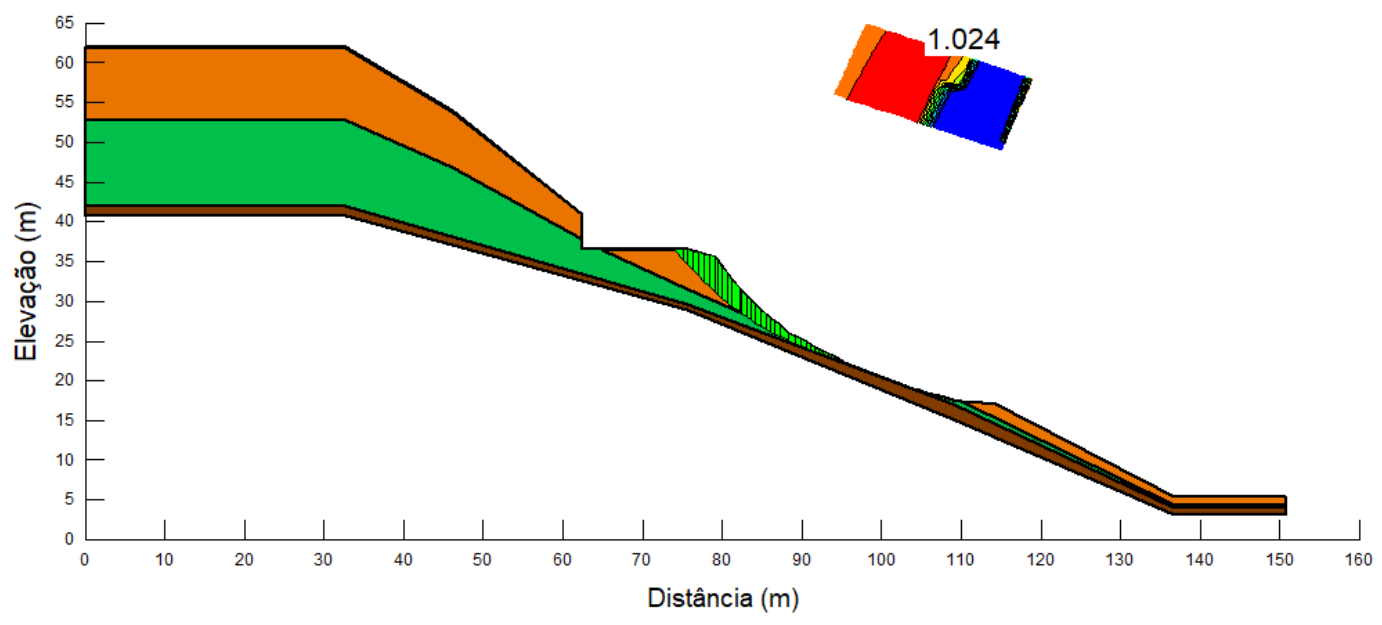

Figura 7.26 - Quarto deslizamento 


\section{8 \\ Conclusões e Sugestões}

\section{1 \\ Conclusões}

\subsection{1}

\section{Caracterização das amostras coletadas}

$\mathrm{Na}$ caracterização física, encontrou-se que, para quase todas as amostras, domina a fração fina. A AM 5 apresentou uma porcentagem de pedregulho e de argila divergente das demais amostras, o que pode ser um indicativo de que esta estaria menos intemperizada. As curvas granulométricas das AM 1, 2 e 4 se mostraram parecidas, com as das AM 3 e 5 diferentes. O mesmo padrão foi encontrado nos limites de consistência.

Quanto à atividade, o grau médio encontrado para o solo 5 pode explicar o comportamento do material da presença de água, o que poderia também ter ocorrido pela porcentagem mais baixa de argila presente no solo, o que reduziu o quociente da equação 5.1 , aumentando o grau de atividade. Este resultado levou à uma investigação mineralógica mais detalhada para esta amostra, já que é possível a existência de argilominerais em outras frações do solo.

Em relação à composição química, conclui-se que os solos coletados aparentam apresentar 3 origens diferentes, de acordo com os mesmos padrões encontrados na análise física. Os solos 1, 2 e 4 foram classificados como coluvionares, já que seus maiores teores de ferro sugerem que são ricos em minerais máficos, o que não ocorre com a rocha-mãe local.

Das análises mineralógicas, viu-se que as amostras são compostas, sobretudo, por quartzo e argilominerais do grupo da caulinita. Os solos 1 a 4 apresentaram altos teores de caulinita bem cristalizada ou baixos teores de caulinita mal cristalizada, concordando com seus graus de atividade. Na fração areia da AM 5, o maior teor de caulinita mal cristalizada pode contribuir para sua maior atividade.

Para as amostras 1 a 3, foram obtidas curvas características de retenção de água com dois pontos de inflexão, correspondendo a seus macroporos e microporos, enquanto para os solos 4 e 5, as curvas se apresentaram unimodais (apenas um ponto de inflexão). Percebe-se que as curvas apresentaram altos valores 
de sucção. Os ajustes, realizados pelo método de Fredlund e Xing (1994), se mostraram satisfatórios.

\subsection{2}

\section{Permeabilidade saturada}

Os ensaios de campo apresentaram permeabilidades consideravelmente maiores que as de laboratório (apenas a AM 3 teve seus valores compatíveis), conforme já é esperado, pela diferença das condições entre estes.

Observou-se também, através dos ensaios de campo, uma camada supercial mais permeável, seguida por camadas de permeabilidade pouco menores e da mesma ordem de grandeza.

Conforme esperado por conta dos fatores listados acima, as análises realizadas para as menores permeabilidades (encontradas em laboratório) não representaram o ocorrido em campo.

\subsection{3 \\ Parâmetros de resistência}

Através dos resultados dos ensaios de cisalhamento direto, foram encontrados dois padrões de resistência: um para as amostras 1, 2 e 4 (assim como na caracterização física e química), com todas apresentando baixos valores de resistência para baixas tensões normais; e outro para as amostras 3 e 5 .

Apesar destes agrupamentos, observou-se que, em termos de resistência, o material coletado é semelhante entre si, com todos tendo apresentado coesão nula e valores próximos de ângulos de atrito.

\subsection{4}

\section{Análises numéricas}

Pelos estudos dos casos admitidos, é possível propor que o provável mecanismo de ruptura do talude do Santo Antônio Além do Carmo se trate de uma ruptura circular retrogressiva, ocorrida no contato entre o solo residual maduro e residual jovem. As análises apontam que este está associado ao aparecimento de um nível d'água na superfície encontrado nas análises de infiltração, ocasionado pela ação das chuvas intensas e lançamento de águas servidas no terreno.

Viu-se que ação antrópica tem um papel fundamental na instabilidade do talude, já que a ruptura só foi reproduzida para o caso em que as águas servidas foram consideradas. Outro fator importante foi a chuva intensa por 2 dias, visto 
que houve, em outros momentos, altos índices pluviométricos em um dia isolado, que não foram capazes de provocar uma elevação do nível d'água que porporcionasse uma situação propensa à ocorrência de um deslizamento.

As maiores permeabilidades, encontradas através dos ensaios de campo, produziram um quadro sem a ocorrência de runoff, com toda a água penetrando no solo, já que a quantidade diária de chuva era sempre menor que sua condutividade hidráulica.

\section{2 Sugestões para futuros trabalhos}

Em relação aos dados experiementais, sugere-se:

- Coleta e avaliação de mais amostras de solo, principalmente do material mais profundo, se possível, para avaliação dos parâmetros utilizados nas análises;

- Maior investigação do solo residual maduro, com realização de tomografia computadorizada para verificação de sua estrutura de poros e microscopia eletrônica de transmissão, para maior entendimento dos fatores que atribuem o grau de atividade médio à este material;

- Realização de mais ensaios de Guelph para se obter um perfil mais preciso de permeabilidade do solo, visto que se trata de um maciço heterogêneo;

- Realização de ensaios de resistência com sucção controlada, para determinação mais precisa da resistência não saturada;

- Realização de ensaios triaxiais do tipo CD (no qual é possível o controle da saturação do corpo de prova) no colúvio saturado e na umidade natural, para baixas tensões normais, para melhor investigação de seu comportamento nesta condição.

Para as análises numéricas:

- Realizar levantamento topográfico do pé do talude, com cadastro das contruções, para melhor exatidão dos resultados, já que este foi interpolado de acordo com seções próximas para este trabalho; 
- Instalação de tensiômetros ou coleta de amostras para determinação da umidade do solo (e assim a sucção) ao decorrer do ano;

- Aplicar a metodologia de Assunção (2005) no local estudado, para quantificação mais exata das águas servidas despejadas no talude. 


\section{9}

\section{Referências bibliográficas}

ABNT - ASSOCIAÇÃO BRASILEIRA DE NORMAS TÉCNICAS. NBR-6502: Solos e rochas. Rio de Janeiro, 1995.

ABNT - ASSOCIAÇÃO BRASILEIRA DE NORMAS TÉCNICAS. NBR-6459: Solo - Determinação do Limite de Liquidez. Rio de Janeiro, 1984b.

ABNT - ASSOCIAÇÃO BRASILEIRA DE NORMAS TÉCNICAS. NBR-6508: Solo - Determinação da massa específica dos grãos. Rio de Janeiro, 1984.

ABNT - ASSOCIAÇÃO BRASILEIRA DE NORMAS TÉCNICAS. NBR-7181: Solo - Análise Granulométrica. Rio de Janeiro, 1984a.

ABNT - ASSOCIAÇÃO BRASILEIRA DE NORMAS TÉCNICAS. NBR-7180: Solo - Determinação do Limite de Plasticidade. Rio de Janeiro, 1984c.

ABNT - ASSOCIAÇÃO BRASILEIRA DE NORMAS TÉCNICAS. NBR-11982: Estabilidade de encostas. Rio de Janeiro, 2006.

ABRAMSON, L. W. Slope stability and stabilization methods. New York: John Wiley \& Sons, 2nd ed., 2001.

ANTUNES, F. S. et al. Solos: subsídio para estudos de geologia de engenharia. Anuário do Instituto de Geociências, UFRJ, 2015, v.38, p. 180-198.

ANTUNES, F.S. Comunicação pessoal, 2018.

AUGUSTO FILHO, O. Caracterização geológico-geotécnica voltada à estabilização de encostas: uma proposta metodológica. Conferência Brasileira Sobre Estabilidade De Encostas, Rio de Janeiro, 1992, p. 721-733. 
AUGUSTO FILHO, O.; VIRGILI, J. C. Estabilidade de taludes. Geologia de Engenharia. São Paulo: Associação Brasileira de Geologia de Engenharia, 1998, p. 243-269.

ASSUNÇÃO, D. M. S. Padrão quali-quantitativo do descarte de águas residuárias em áreas carentes: um estudo no Alto do Bom Viver em Salvador. Dissertação de Mestrado, MEAU, Universidade Federal da Bahia, Salvador, 2005.

BISHOP, A. W. The principle of effective stress. Tecknik Ukebland, v. 106, n. 39, p. 859-863, 1959.

BLIGHT, G. E. Aspects of the capillary model foi unsaturated soils. Proceedings of the $7^{\text {th }}$ Asian Reg. Conf. on S.M.F.E., Haifa, v.1, p. 1-7, 1983.

BLIGHT, B. Origin and formation of residual soils. Mechanics of Residual Soil, p. 1-15, 1997.

CAJADO, R. B.S.; CAMPOS, L. E. P. Utilização do Permeâmetro Ghelph para estudo e determinação da condutividade hidráulica da Região da falha geológica de Salvador. Conferência Brasileira sobre Estabilidade de Encosta, Florianópolis, v.1, 7 p.

CALLE, J. A. C. Análise de ruptura de talude em solo não saturado. $177 \mathrm{p}$. Dissertação de Mestrado, Universidade de São Paulo, São Carlos, 2000.

CAMPOS, L. E. P. Influência da sucção na estabilidade de taludes naturais em solos residuais. Dissertação de mestrado, DEC, PUC - Rio, Rio de Janeiro, 1984.

CAMPOS, L. E. P. Parecer técnico preliminar: Encosta Chácara do Santo Antônio. Salvador: UFBA - EP - DCTM, 2011, 10 p. Relatório Técnico.

CASO, J. M. E. Características de resistência não saturada de um solo coluvionar e um solo saprolítico de Tinguá, RJ. Dissertação de mestrado, DEC, PUC - Rio, Rio de Janeiro, 2014, 177 p. 
CHANDLER, R. J.; CRILLY, M. S.; MONTGOMERY-SMITH, G. A low cost method of assessing clay desiccation foi low-rise buildings. Proceedings of te Instituion of Civil Engineers, 1992, v.2, no. 2, p. 82-89.

CORREIA, E. S. et al. Estudo ambiental em áreas de falha geológica de Salvador: encostas da Lapinha e Santo Antônio. Salvador: SENAI, 2009, 113 p. Relatório Técnico.

CODESAL. Plano de Ação: encosta do Santo Antônio. Prefeitura Municipal de Salvador, 2011, 15 p. Relatório técnico.

DE CAMPOS, T. M. P. Resistência ao cisalhamento de solos não saturados. 3o Simpósio Brasileiro de Solos Não Saturados, Rio de Janeiro, 1997, v.2, p. 399417.

DE CAMPOS, T. M. P.; MOTTA, M. F. B. Resistência ao cisalhamento de solos não saturados. In: Camapum de Carvalho, J. et al. (Org.). Solos não saturados no contexto geotécnico. ABMS, São Paulo, 2015, p. 465-497.

DE CAMPOS, T. M. P.; et al. Failure mechanisms of unsaturated soil slopes under rains-torms in Rio de Janeiro, Brazil: an overview. Não publicado. 2018, $23 \mathrm{p}$.

DECAGON DEVICES. Operator's Manual Dewpoint PotencialMeter. Inc. 2365 NE Hopkins Court Pullman, WA 99163 USA, 2010, 66p.

DELCOURT, R. T. Avaliação das características de resistência de um solo residual saturado de acordo com o grau de intemperismo e interpretação através da Teoria dos Estados Críticos. Proposta de Tese de Doutorado, DEC, PUC - Rio, Rio de Janeiro, 2015, 141 p.

DELGADO, C. W. C. Resistência ao cisalhamento dos solos coluvionares e residuais não saturados na vista chinesa, $\mathbf{R J}$. Dissertação de mestrado, DEC, PUC - Rio, Rio de Janeiro, 1993, 159 p. 
DIAS, N. R. Impactos sócioambientais da ocupação espontânea em áreas de riscos a movimentos de massa na Avenida Afrânio Peixoto. Monografia, Universidade Federal da Bahia, IGEO, Salvador, 2014, 65 p.

EDIL, T. B.; MOTAN, S. E.; TOHA, F. X. Mechanical behavior and testing method of unsaturated soils. Lab shear strength of soils, 1981.

ELBACHÁ, A. T. Estudo da estabilidade de encostas em áreas pauperizadas de Salvador. Monografia, UFBA, DTCM, Salvador, 1992, 189 p.

ESCARIO, V. Formulae for the shear strength envelope of partially saturated soils. Report 68, Ingenieria Civil, CEDEX, Madrid, Spain, 1988.

FABRÍCIO, J. V. F. Análises probalísticas da estabilidade de taludes e contenções. Dissertação de mestrado, DEC, PUC - Rio, Rio de Janeiro, 2006, $170 \mathrm{p}$.

SOILVISION. SoilVision users manual. Version 5.3.07, SoilVision Systems Ltd., Saskatoon, Saskatchewan, Canada, 2017.

FREDLUND, D. G.; KRAHN, J. Comparison of slope stability method of analysis. Canadian Geotechnical Journal, 1977, v. 14, p. 429-439.

FREDLUND, D. G.; MORGENSTERN, N. R. Stress state variablies for unsaturated soils. Journal of the Geotechnical Engineering Division, 1977, v. 103, n. GT5, p. 447-466.

FREDLUND, D. G.; RAHARDJO, H. Soil mechanics for unsaturated soils. New York: John Wiley \& Sons, INC, 1993.

FREDLUND, D. G.; MORGENSTERN, N. R.; WIDGER, R. A. The shear strength of unsaturated soils. Canadian Geotechnical Journal, 1978, 15(3), p.313-321.

FREDLUND, D.G; XING, A. Equations for the soil-water characteristic curve. Canadian Geotechnical Journal, 31: 521-532, 1994. 
FREDLUND, D. G.; XING, A. E HUANG, S. Predicing the permeability function for unsaturated soils using the soil-water characteristic curve. Canadian Geotechnical Journal, 1994, v. 31, p. 533-546.

FREDLUND, D G.; RAHARDJO, H.; FREDLUND, M. D. Unsaturated soil mechanics in engineering practice. New Jersey: John Wiley \& Sons, 2012.

FUTAI, M. M. Estudo teórico-experimental do comportamento de solos tropicais não saturados: aplicação ao mecanismo de voçorocamento. Tese de doutorado, Universidade Federal do Rio de Janeiro (COPPE), Rio de Janeiro, 2002, 559 p.

GEOENG. Anterpojeto de engenharia: estabilidade de encostas - Santo Antônio Além do Carmo. Salvador: 2014, 31 p. Relatório Técnico.

GEORGETTI, G. B. Resistência de um solo não saturado a partir de ensaios com teor de umidade constante (CW). Dissertação de mestrado, Universidade de São Paulo, São Carlos, 2010, 108 p.

GERSCOVICH, D. M.S. Fluxo em meios porosos saturados-não saturados: modelagem numérica com aplicações ao estudo da estabilidade de encostas no Rio de Janeiro. Tese de doutorado, DEC, PUC - Rio, Rio de Janeiro, 1994, $275 p$.

GERSCOVICH, D. M.S., VARGAS JR, E. A.; DE CAMPOS, T. M. P. Estabilidade de taludes. In: Camapum de Carvalho, J. et al. (Org.). Solos não saturados no contexto geotécnico. ABMS, São Paulo, 2015, p. 613-632.

GERSCOVICH, D.M.S. et al. Estabilidade de Taludes. São Paulo: Oficina de Textos. $2^{\mathrm{a}}$ ed, 2016.

GEOSTUDIO. Stability modeling with GeoStudio. Calgary, Alberta, Canada, 2017.

GEOSTUDIO. Heat and mass transfer modeling with GeoStudio 2018. Second Edition. Calgary, Alberta, Canada, 2018. 
GITIRANA JR, G. F. N.; MARINHO, F. A. M.; SOTO, M. A. A. A curva de retenção de água de materiais porosos. In: Camapum de Carvalho, J. et al. (Org.). Solos não saturados no contexto geotécnico. ABMS, São Paulo, 2015, p. 205-229.

GUIDICINI, G.; NIEBLE, C. M. Estabilidade de taludes naturais e de escavação. São Paulo: Edhard Blucher, 1983.

INMET. Dados históricos, Módulo de Estudo e Pesquisa. Disponível em: $<$ http://www.inmet.gov.br/portal/index.php? $r=b d m e p / b d m e p>$. Acesso em: 03 jun. 2018.

JESUS, A. C. Retroanálise de escorregamentos em solos residuais não saturados. Dissertação de mestrado, Universidade de São Paulo, São Carlos, 2008, $283 p$.

KHALILI, N.; KHABBAZ, M. H. A unique relationship for the determination of the shear strength of unsaturated soils. Géotechnique, 48(5), p. 681-687, 1998.

LOPES, M. B. L. Influência da sucção na resistência ao cisalhamento de um solo residual de filito de Belo Horizonte, MG. Dissertação de mestrado, DEC, PUC - Rio, Rio de Janeiro, 2006, 175 p.

LU, N.; LIKOS, W. J. Unsaturated Soil Mechanics. John Wiley \& Sons, 2004.

LUMB, P. Slope failure in Hong Kong. Quarterly Journal of Engineering Geology, 1995, v.8, p. 31-65.

LYTTON, R. L. Foudations and pavements on unsaturated soils, ed. Alonso and Delage. Proceedings of the 1st International Conference on Unsaturated Soils, Paris, Bakema, 1996, v.3, p. 1201-1220.

MAIA, E. C. B. et al. Caracterização geológica-geotécnica do talude localizado no Comércio - Ladeira do Pilar. Conferência Brasileira sobre Estabilidade de Encosta, Florianópolis, vol 1. 
MARINHO, F. A. M. Medição de sucção com o método do papel filtro. In: X Congresso Brasileiro de Mecânica dos Solos e Engenharia de Fundações, Foz do Iguaçu, PR, 1994, v.2, p. 515-522.

MARINHO, F.A.M. Medição de sucção em solos. III Simpósio Brasileiro de Solos Não-Saturados, Rio de Janeiro, 1997, v.1, p.373-397.

MARINHO, F.A.M; OLIVEIRA, O. M. The Filter Paper Method Revisited. Geotechnical Testing Journal, ASTM, 2006, v.29, n.3.

MIAO, L., YIN, Z., AND LIU, S. Empirical function representing the shear strength of unsaturated soils. Geotechnical Testing Journal, ASTM, 2001, 24(2): 220-223.

MORGENSTERN, N. R; PRICE, V. E. The analysis of the stability of general surfaces. Geotechique, 1965, v.15, p. 79-83.

MOTTA, M. F. B. Caracterização Físico-Hídrico-Estrutural e Efeito do Aumento da Pressão do Ar na Resistência de Solos Tropicais Não Saturados. Tese de Doutorado, DEC, PUC - Rio, Rio de Janeiro, 2016.

OBERG, A.; SALLFORS, G. Determination of shear strength parameters of unsaturated silts and sands based on water retention curve. Geotechnical Testing Journal, 1997, 20(1), p. 40-48.

OLIVEIRA, C. M. M. Avaliação dos mecanismos de ruptura associados aos escorregamentos da Prainha e Condomínio em Nova Friburgo, Rio de Janeiro. Dissertação de Mestrado, DEC, PUC - Rio, Rio de Janeiro, 2013, 105 p.

PREFEITURA MUNICIPAL DE SALVADOR (PMS). Plano Diretor de Encostas. Secretaria Municipal do Saneamento e Infraestrutura Urbana. Módulo II Diagnóstico, TOMO I/III, 2004, p. 10-173.

PROJETO CAMINHOS GEOLÓGICOS DA BAHIA. Salvador: Cidade Alta e Cidade Baixa, por quê? Painel: color, 2004. 
RAHARDJO, H., SATYANAGA, A.; LEONG, E. C. Unsaturated Soil Mechanics for Slope Stabilization. 5th Asia Pacific Conference in Unsaturated Soils. Thailand, 2011, p. 103-117.

REIS, R.M. Comportamento tensão deformação de dois horizontes de um solo residual de gnaisse. Tese de Doutorado, Universidade de São Paulo, São Carlos, 2004, $190 \mathrm{p}$.

REIS, E. S. et al. Análise de deslizamentos na Falha de Salvador: o caso da comunidade Chácara de Santo Antônio. Universidade Federal da Bahia, Salvador, 2012, 16 p.

RIBEIRO, D. A. Gentrification no Parque Histórico do Pelourinho. Dissertação de mestrado, Universidade Federal da Bahia, IGEO, Salvador, 2001, 256 p.

ROCHA, M. F. et al. Estudo comparativo de técnicas de medição de sucção total do solo: papel filtro e um potenciômetro de ponto de orvalho. Congresso Brasileiro de Mecânica dos Solos e Engenharia Geotécnica. Goiânia, 2014.

SANTOS, A. B. Avaliação de Ruptura em Solos não Saturados: Um Estudo de Caso do Talude do Morro do Águia, em Salvador. Dissertação de mestrado, DEC, PUC - Rio, Rio de Janeiro, 2017, 160 p.

SILVA, J. C. B. J. Solos grampeados - comprimentos máximos de grampos nos solos a lesse da Falha de Salvador (BA). Sitientibus, Feira de Santana, 2006, n.35, p.57-74.

SILVA, T. A. Avaliação da influência da sucção mátrica e do grau de intemperismo no coeficiente de empuxo lateral (KO) em solos residuais. Dissertação de mestrado, DEC, PUC - Rio, Rio de Janeiro, 2017, 105 p.

SOARES, R. M. Resistência ao cisalhamento de um solo coluvionar não saturado do Rio de Janeiro, RJ. Dissertação de mestrado, DEC, PUC - Rio, Rio de Janeiro, 2005, 196 p. 
VANAPALLI, D. G.; FREDLUND, D. G.; PUFAHL, D. E.; CLIFTON, A. W. Model for the prediction of shear strength with respect to soil suction. Canadian Geotechnical Journal, 1996, 33, p. 379-392.

VANAPALLI, D. G.; PUFAHL, D. E.; FREDLUND, D. G. The effect of soil structure and stress history on the soil-water characteristics of a compacted till. Géotechnique, 49 (2), p.143-159, 1999.

VILAR, O. M. A simplified procedure to estimate the shear strengh envelope of unsaturated soils. Canadian Geotechnical Journal, 2006, 43, p. 1088-1095. 


\section{Anexo I - Perfis de sondagem}

\begin{tabular}{|c|c|c|c|c|}
\hline & & PERFIL INDIVIDUAL DE SONDAGEM A PERCUSSÃO & $\begin{array}{l}\text { No DOC: } \\
\text { DATA: } \\
\text { REV:: }\end{array}$ & $\begin{array}{c}079 / 14 \\
19 / 03 / 2014 \\
0\end{array}$ \\
\hline CLIENTE: & CONDER - COI & ANHIA DE DESENVOLVIMENTO URBANO DO ESTADO DA BAHIA & DATA INICIO: & $14 / 03 / 2014$ \\
\hline OBRA: & ENCOSTA & & DATA FINAL: & 17/03/2014 \\
\hline LOCAL: & COMÉRCIO/SA & TO ANTÖNIO, SALVADOR/BA & SONDAGEM: & SP - 01 \\
\hline
\end{tabular}

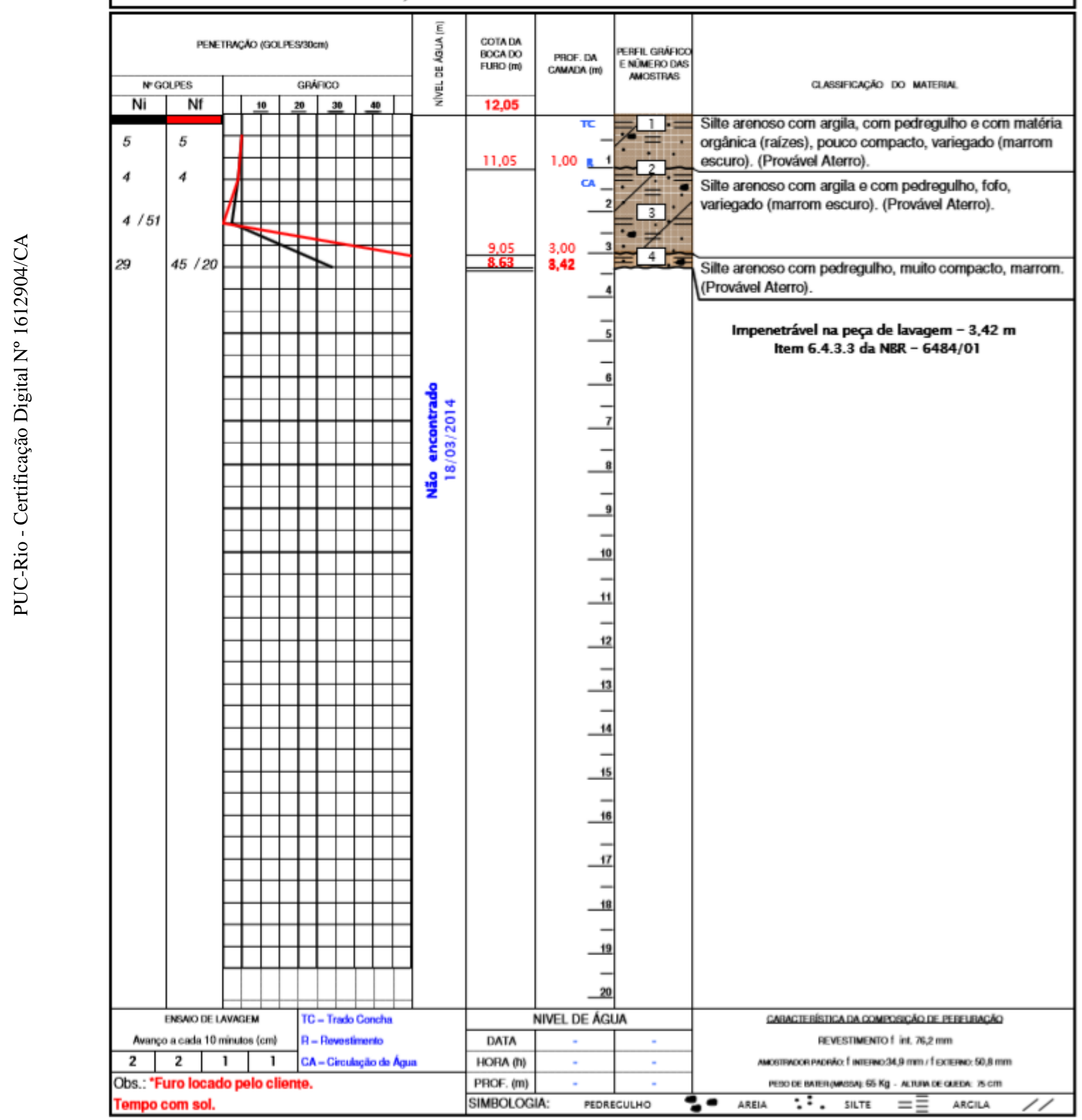




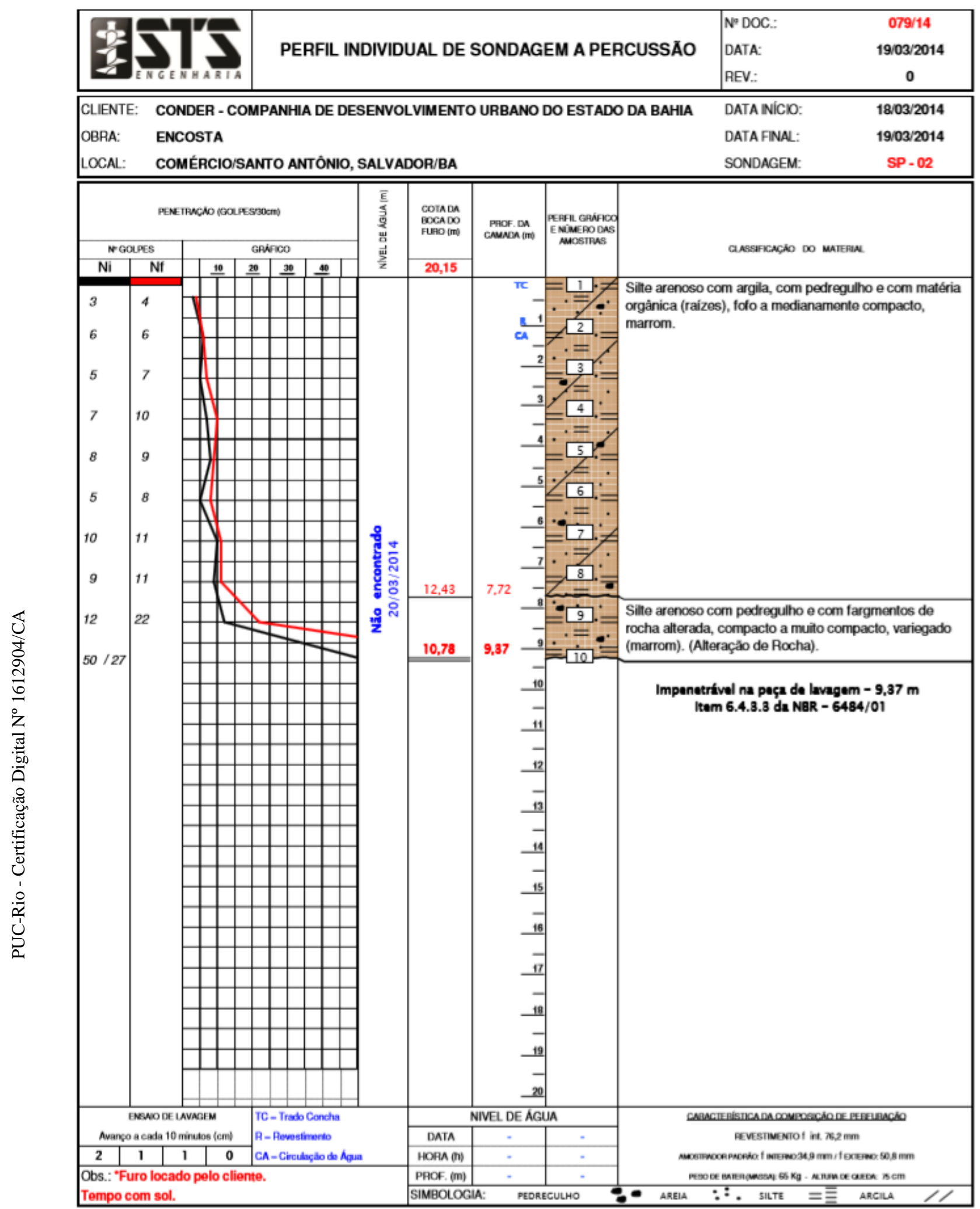




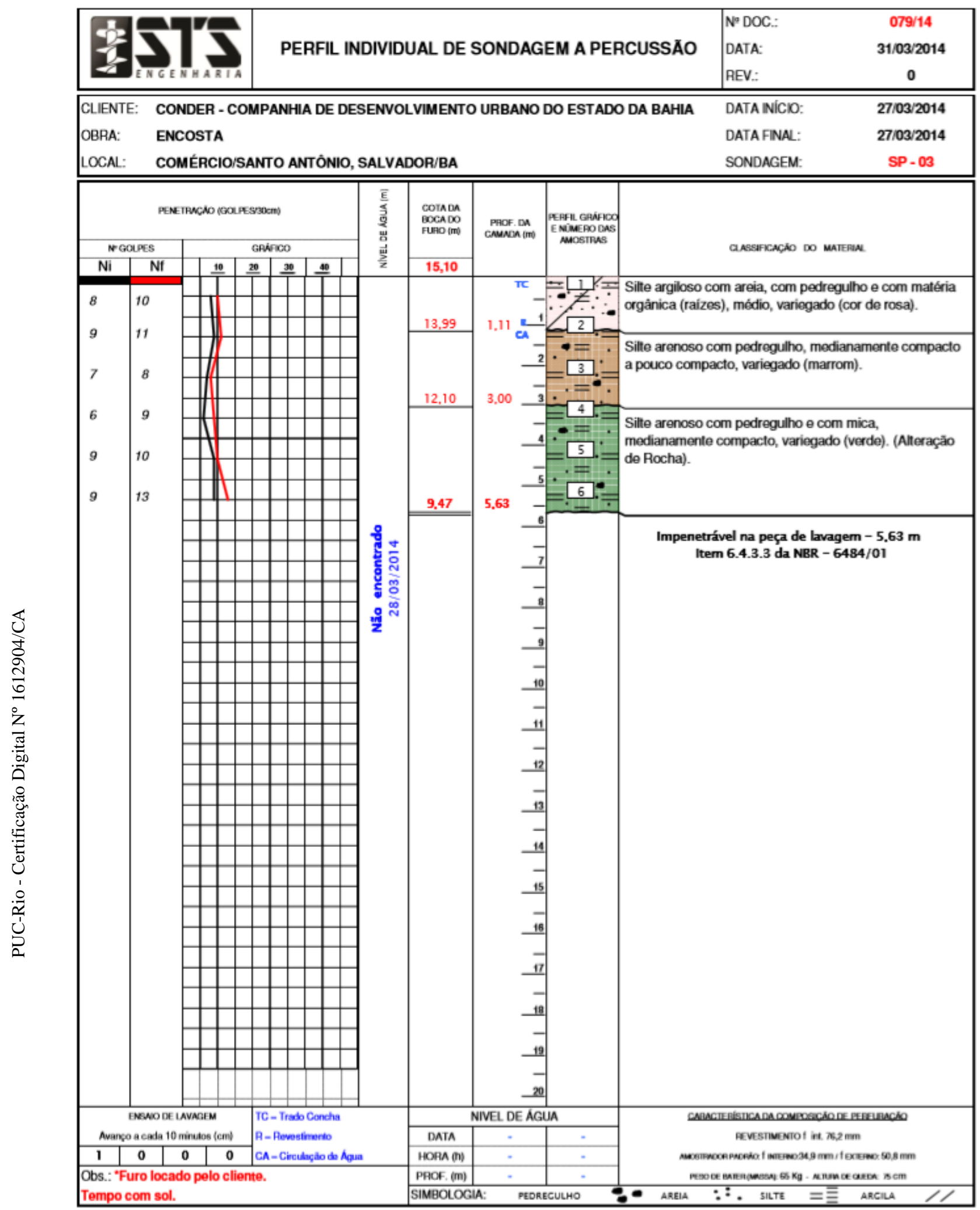




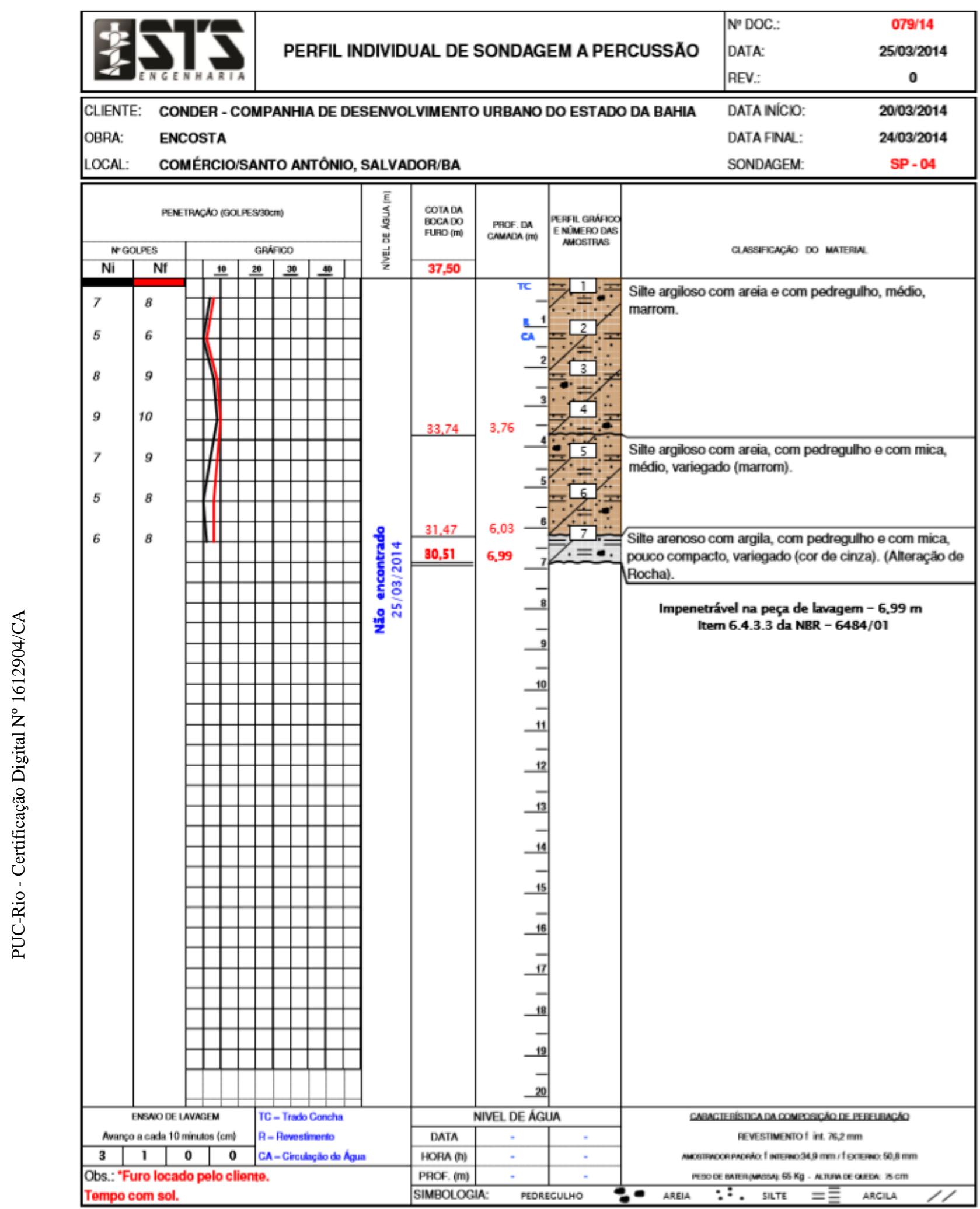




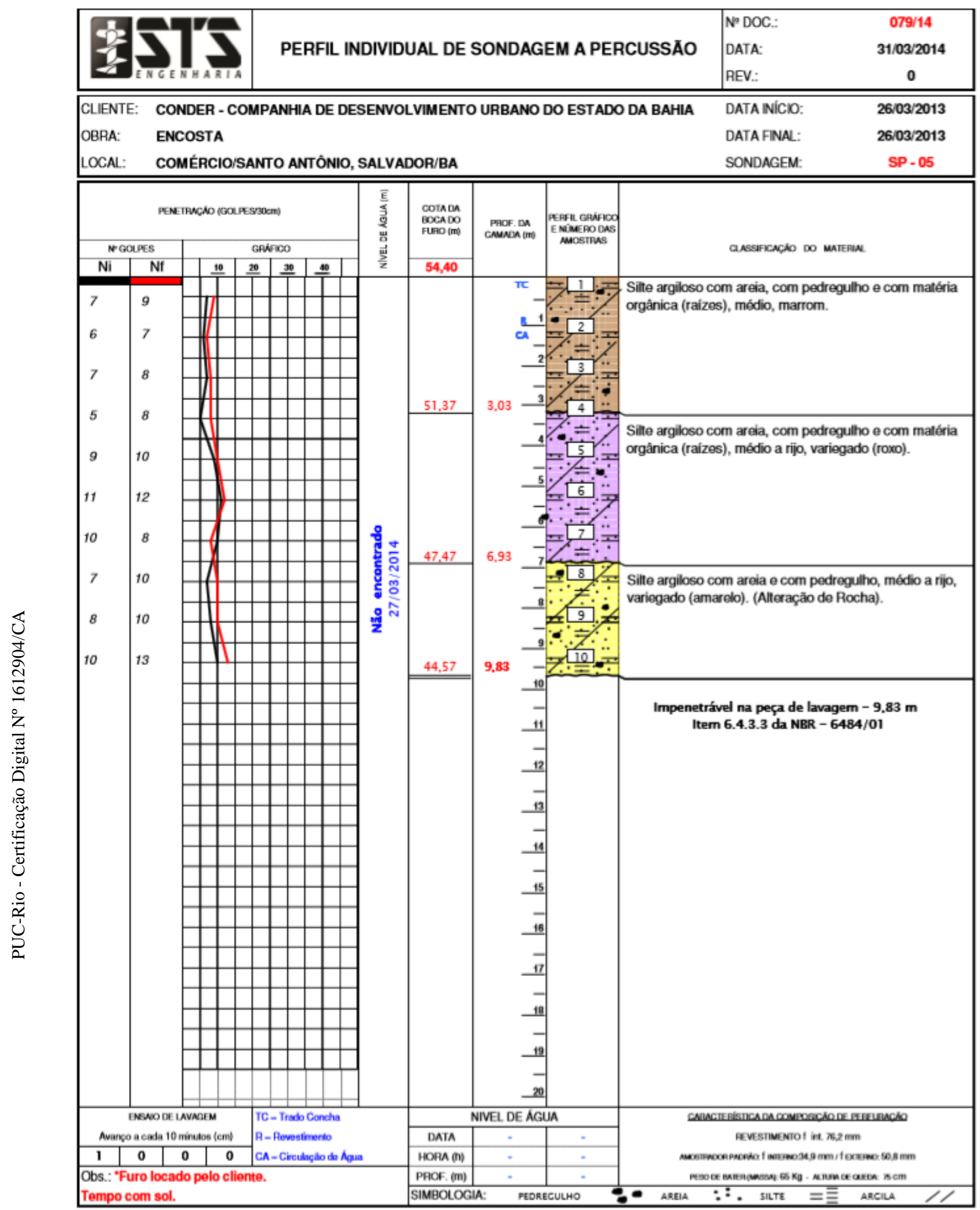




\section{FTIJ}

$\begin{array}{lc}\text { NN DOC: } & 079 / 14 \\ \text { DATA: } & 31 / 03 / 2014 \\ \text { REV }: & 0\end{array}$

CLIENTE: CONDER - COMPANHIA DE DESENVOLVIMENTO URBANO DO ESTADO DA BAHIA

DATA INICIO:

$25 / 03 / 2014$

OBRA: ENCOSTA

DATA FINAL:

$25 / 03 / 2014$

LOCAL: COMÉRCIO/SANTO ANTÔNIO, SALVADOR/BA

SONDAGEM:

SP - 06

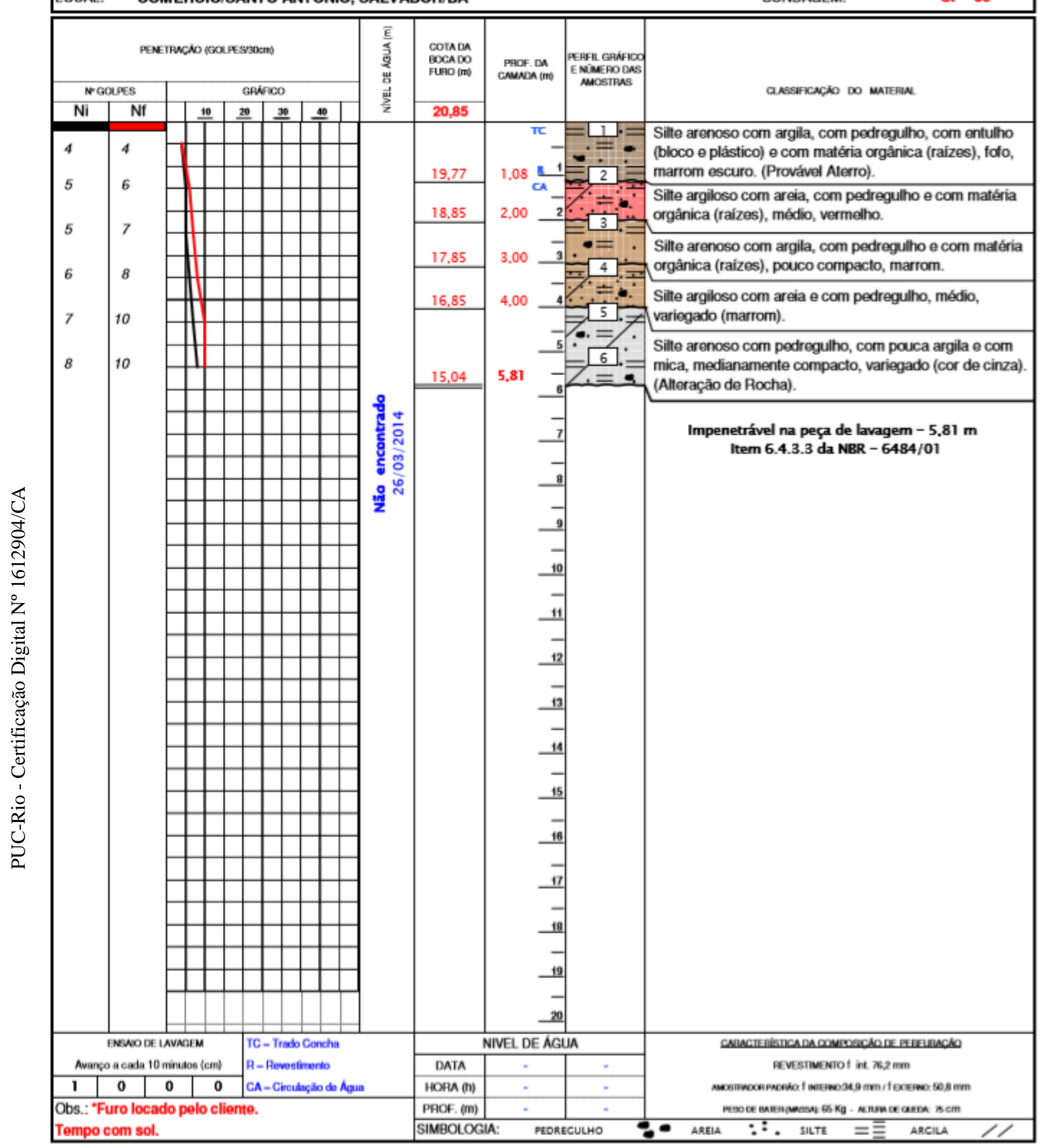




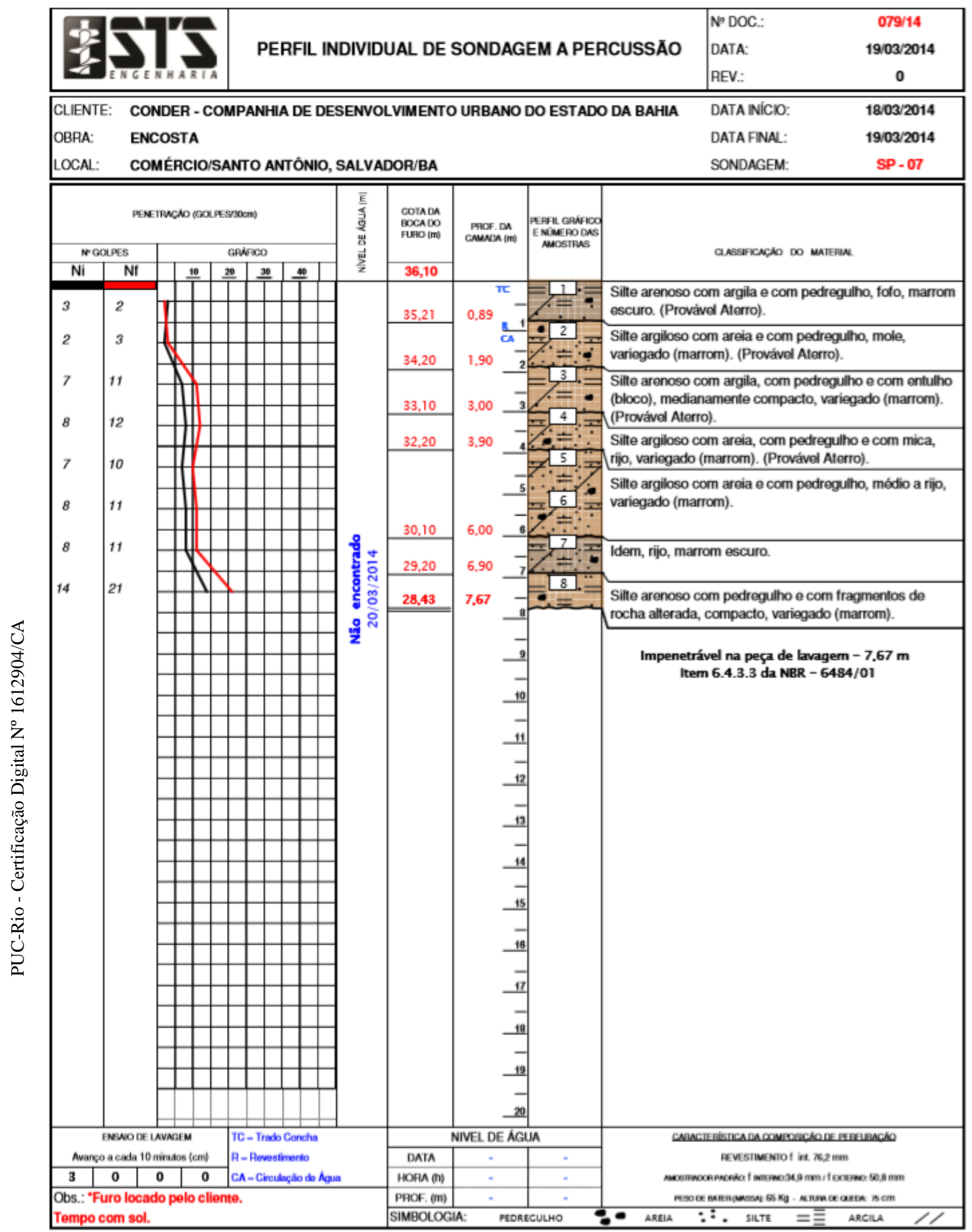




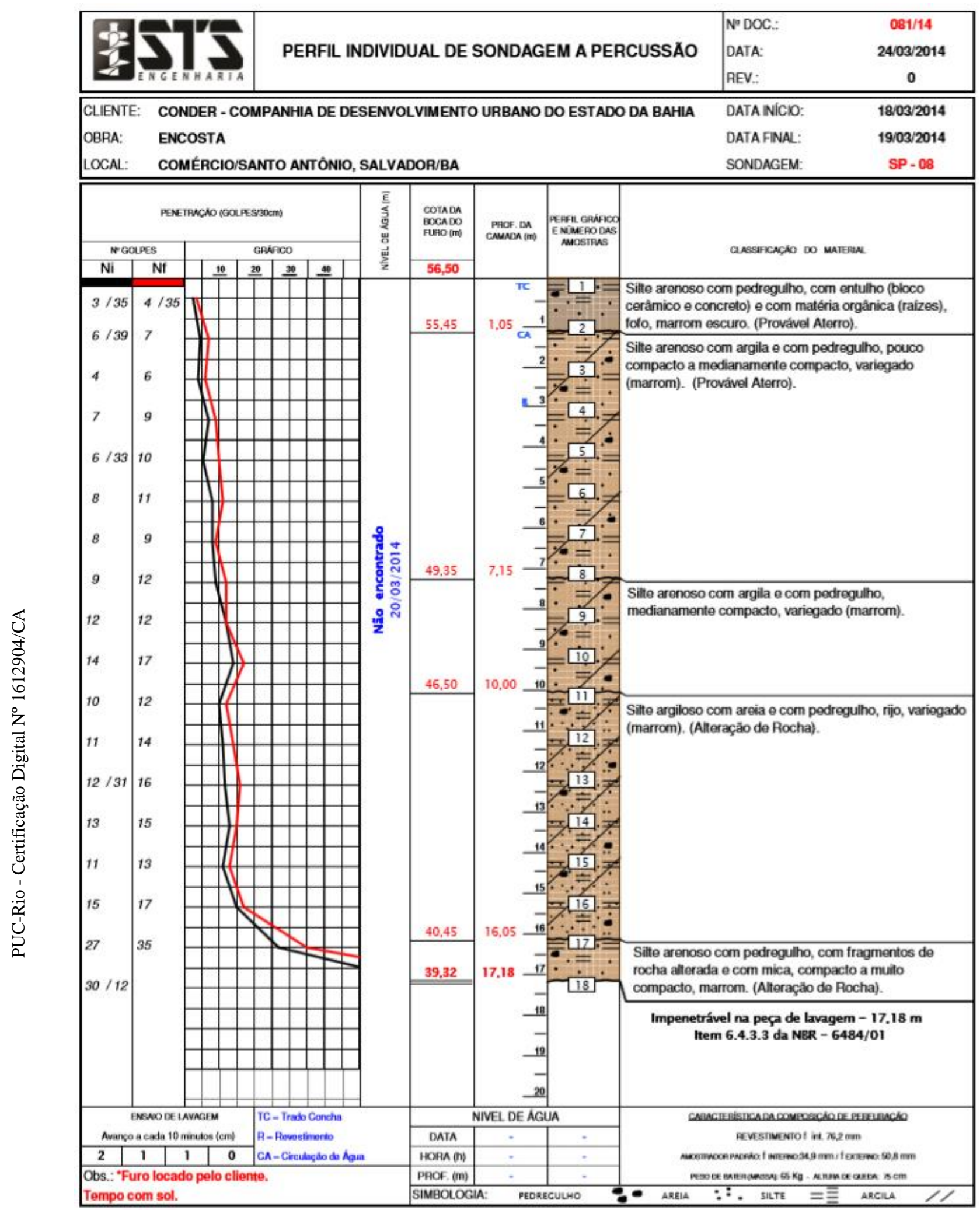



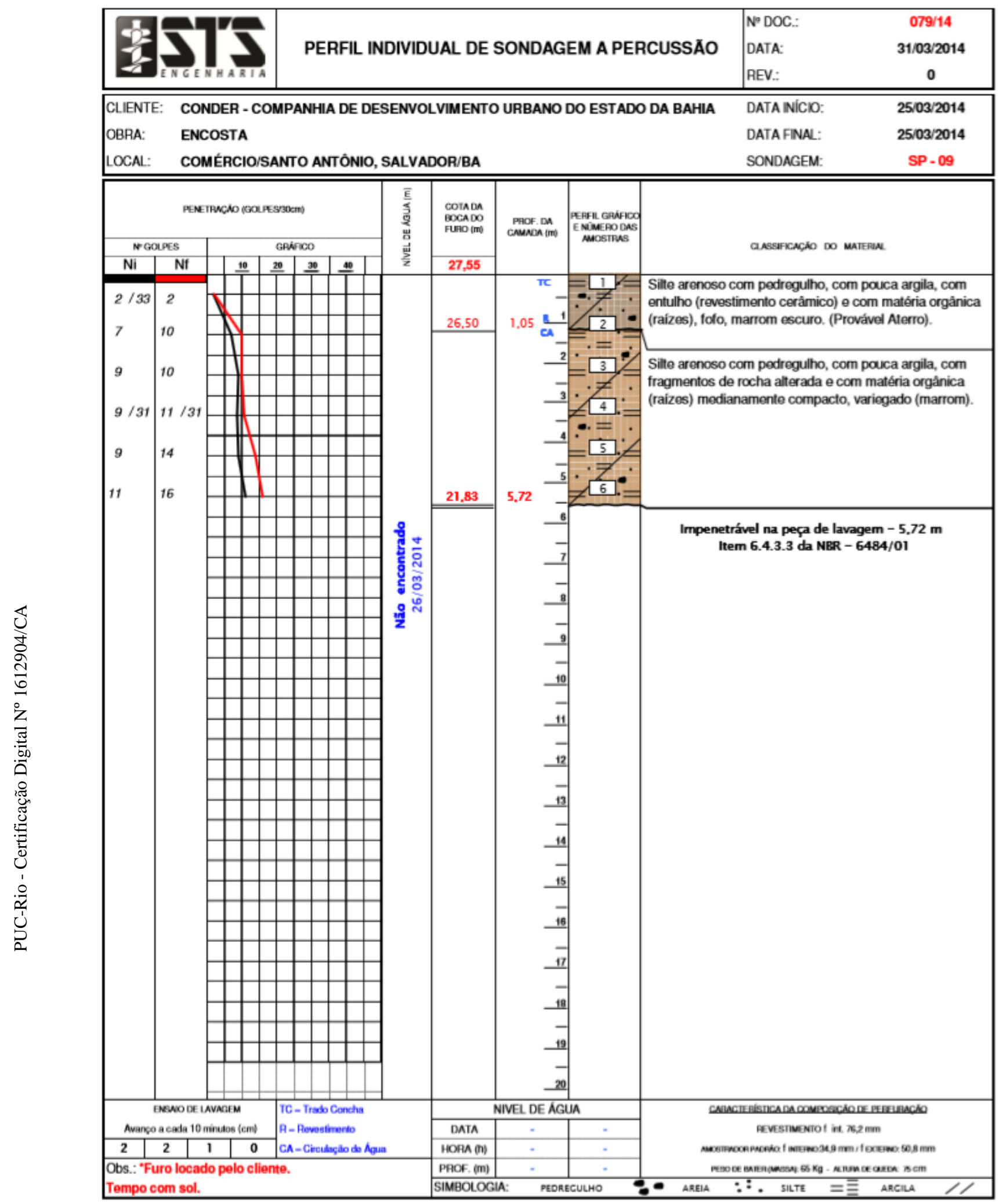


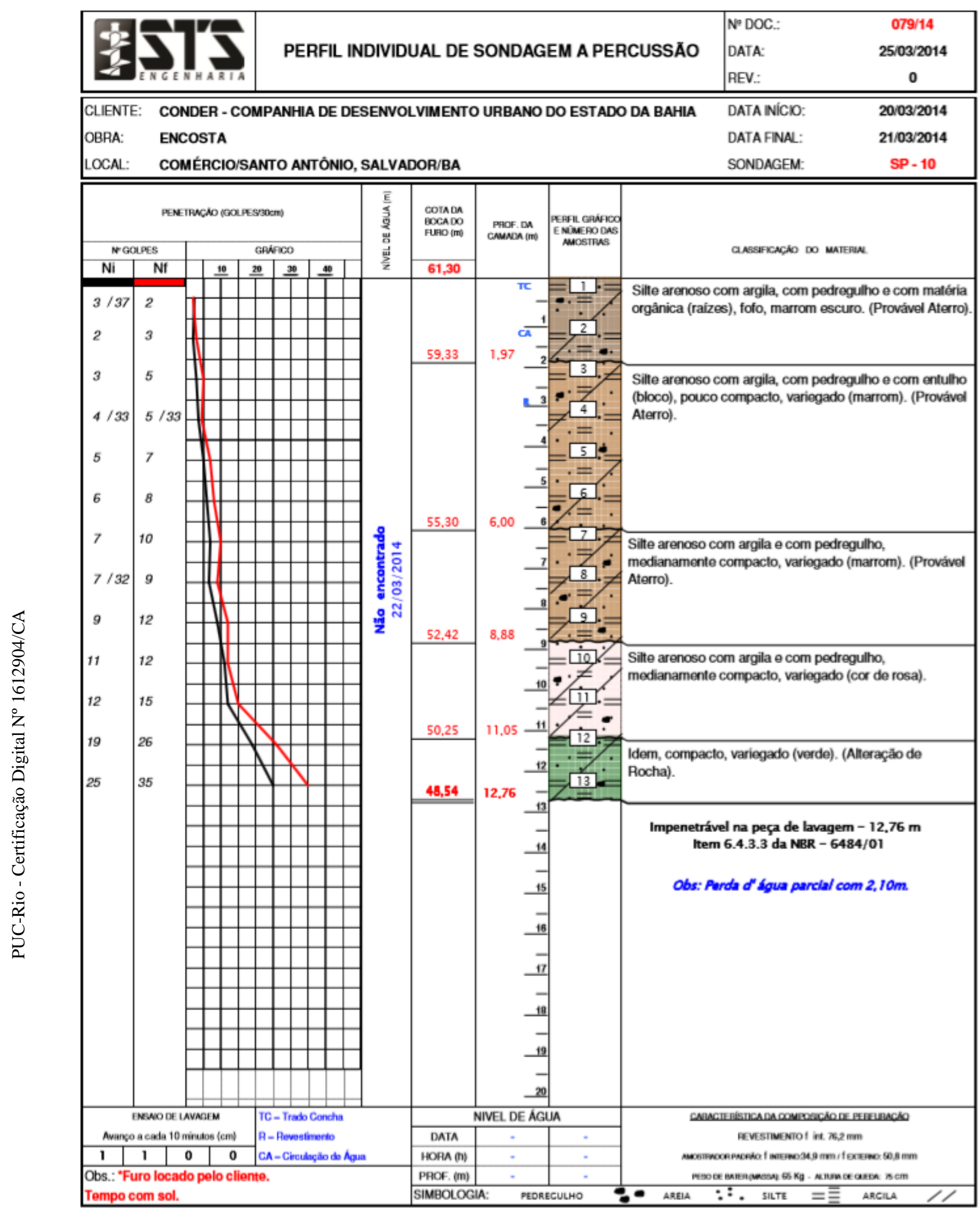




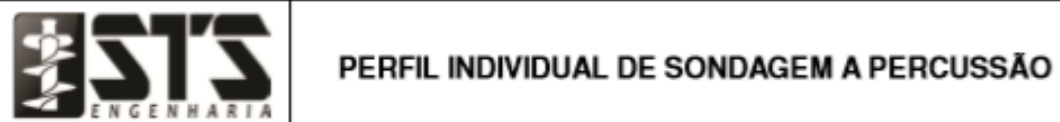

\begin{tabular}{lc} 
No DOC: & $079 / 14$ \\
DATA: & $25 / 03 / 2014$ \\
REV : & 0 \\
\hline
\end{tabular}

CLIENTE: CONDER - COMPANHIA DE DESENVOLVIMENTO URBANO DO ESTADO DA BAHIA

DATA INICIO:

20/03/2014

OBRA: ENCOSTA

DATA FINAL:

$24 / 03 / 2014$

LOCAL: COMÉRCIO/SANTO ANTÔNIO, SALVADOR/BA

SONDAGEM:

SP - 11

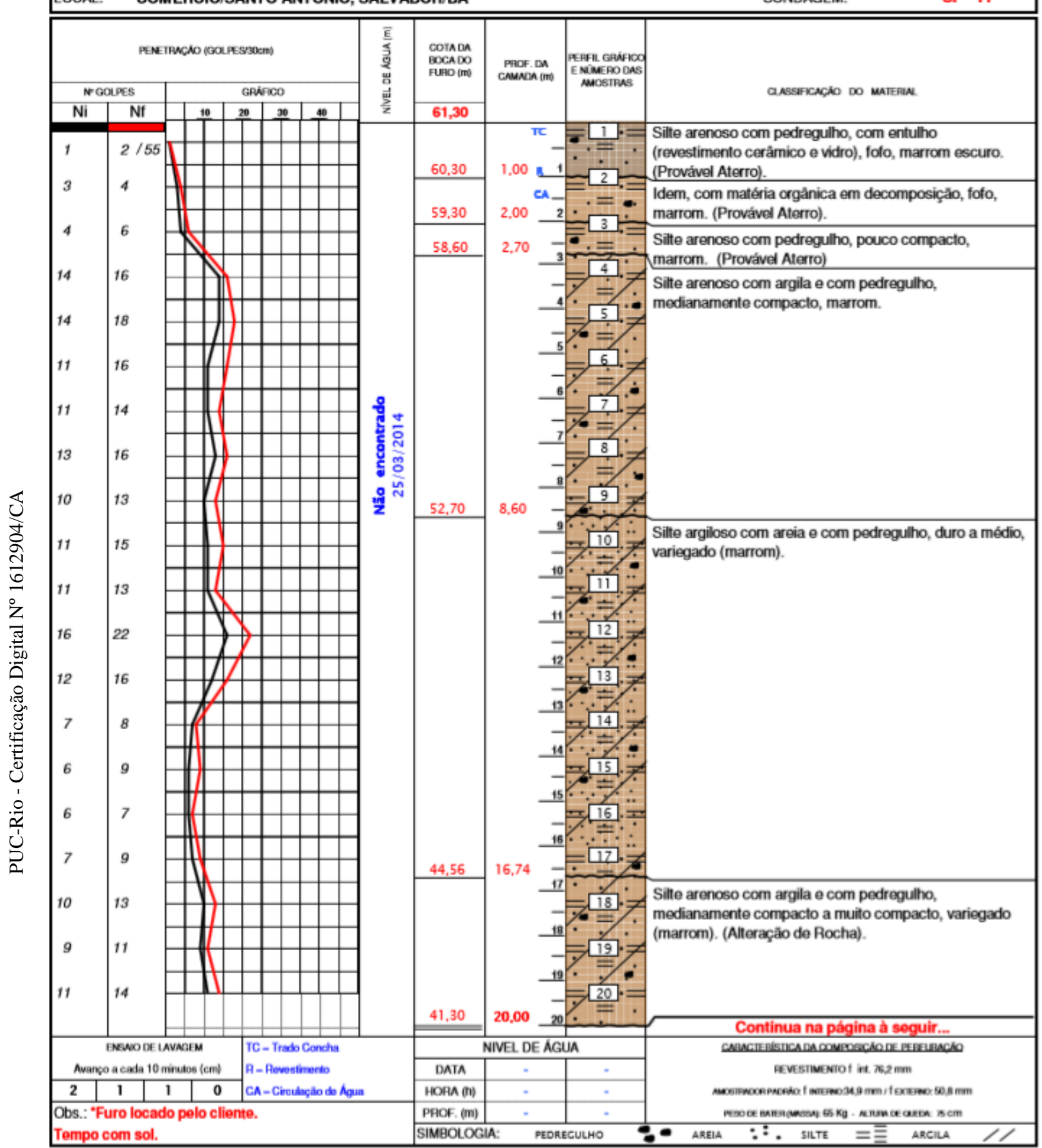




\section{ETS \\ ESEnços LToA PERFIL INDIVIDUAL DE SONDAGEM A PERCUSSÃO}

CLIENTE: CONDER - COMPANHIA DE DESENVOLVIMENTO URBANO DO ESTADO DA BAHIA

OBRA: ENCOSTA

LOCAL: COMÉRCIO/SANTO ANTONNIO, SALVADOR/BA

No DOC:

DATA

073/14

REV: :

25/03/2014

0

DATA INICIO: $\quad 20 / 03 / 2014$

DATAFINAL: $\quad 24 / 03 / 2014$

SONDAGEM:

SP - 11

Cont.

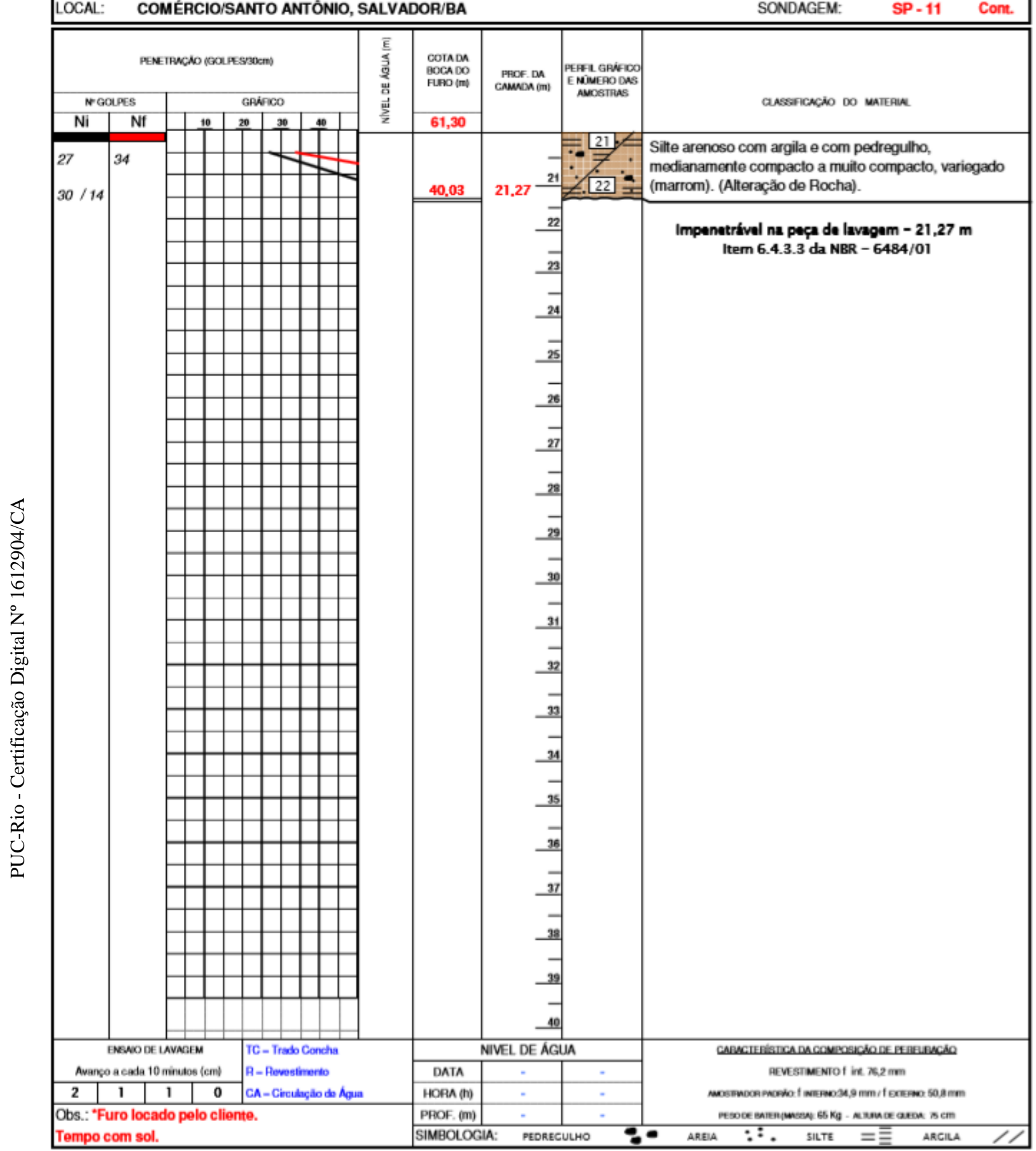




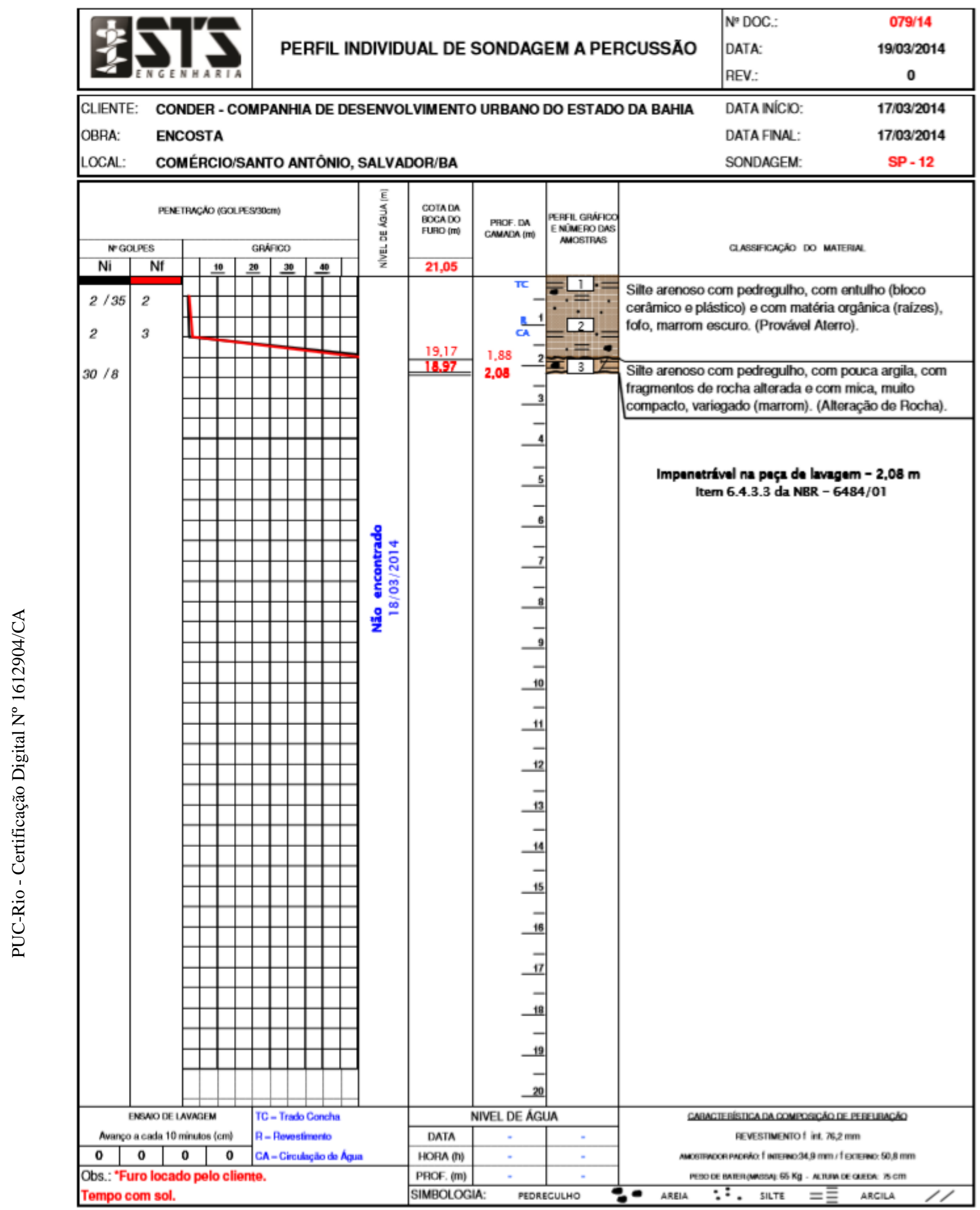




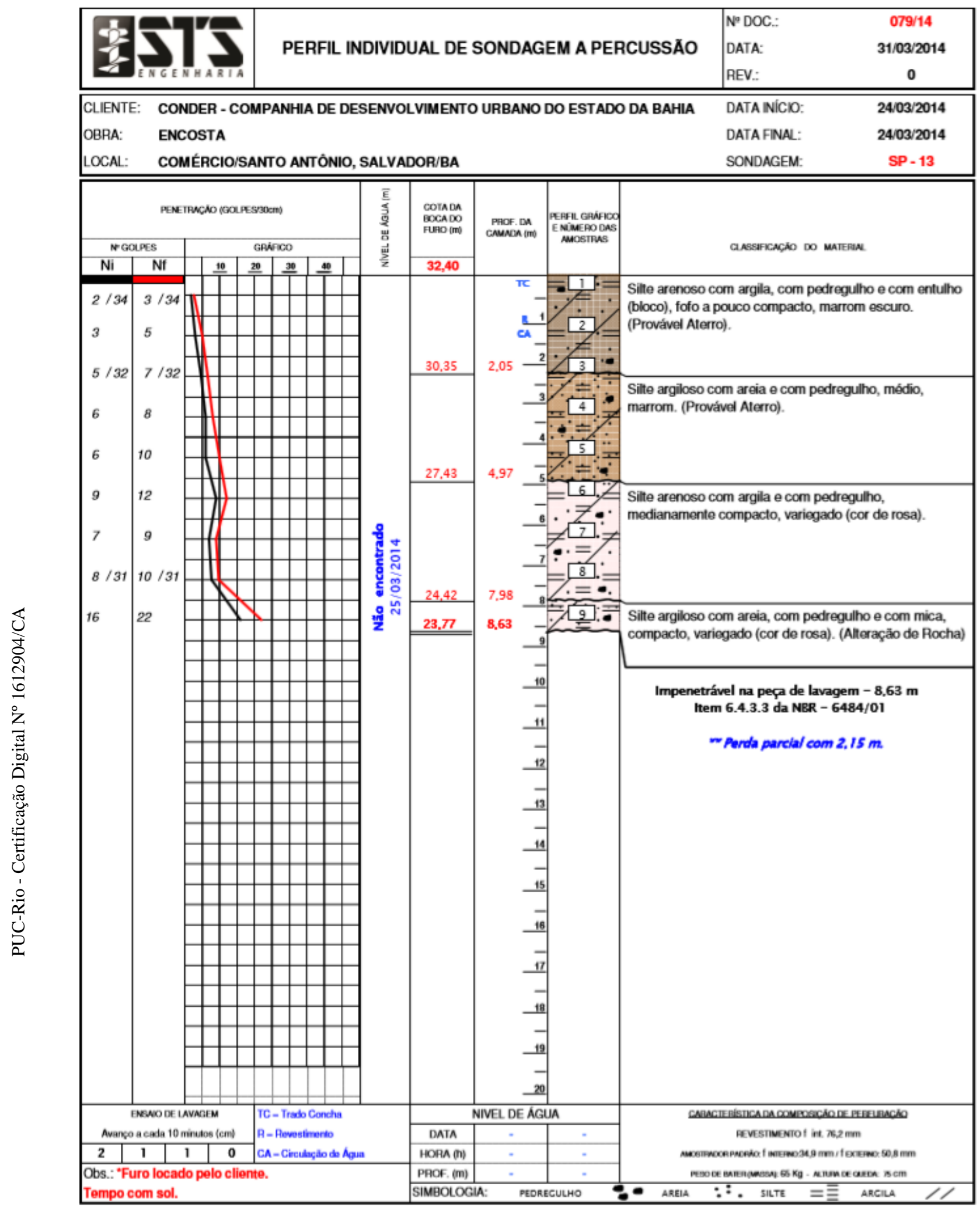




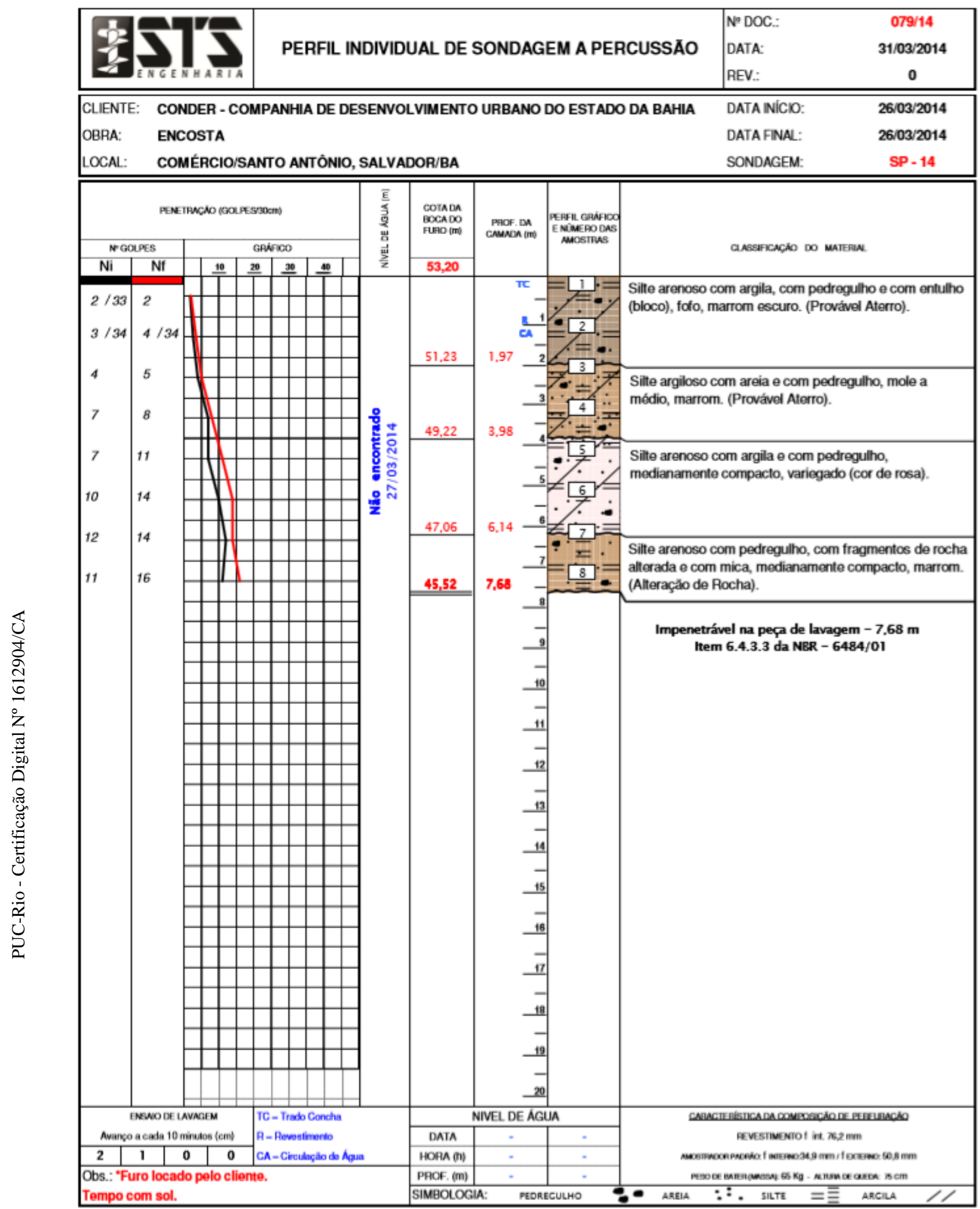




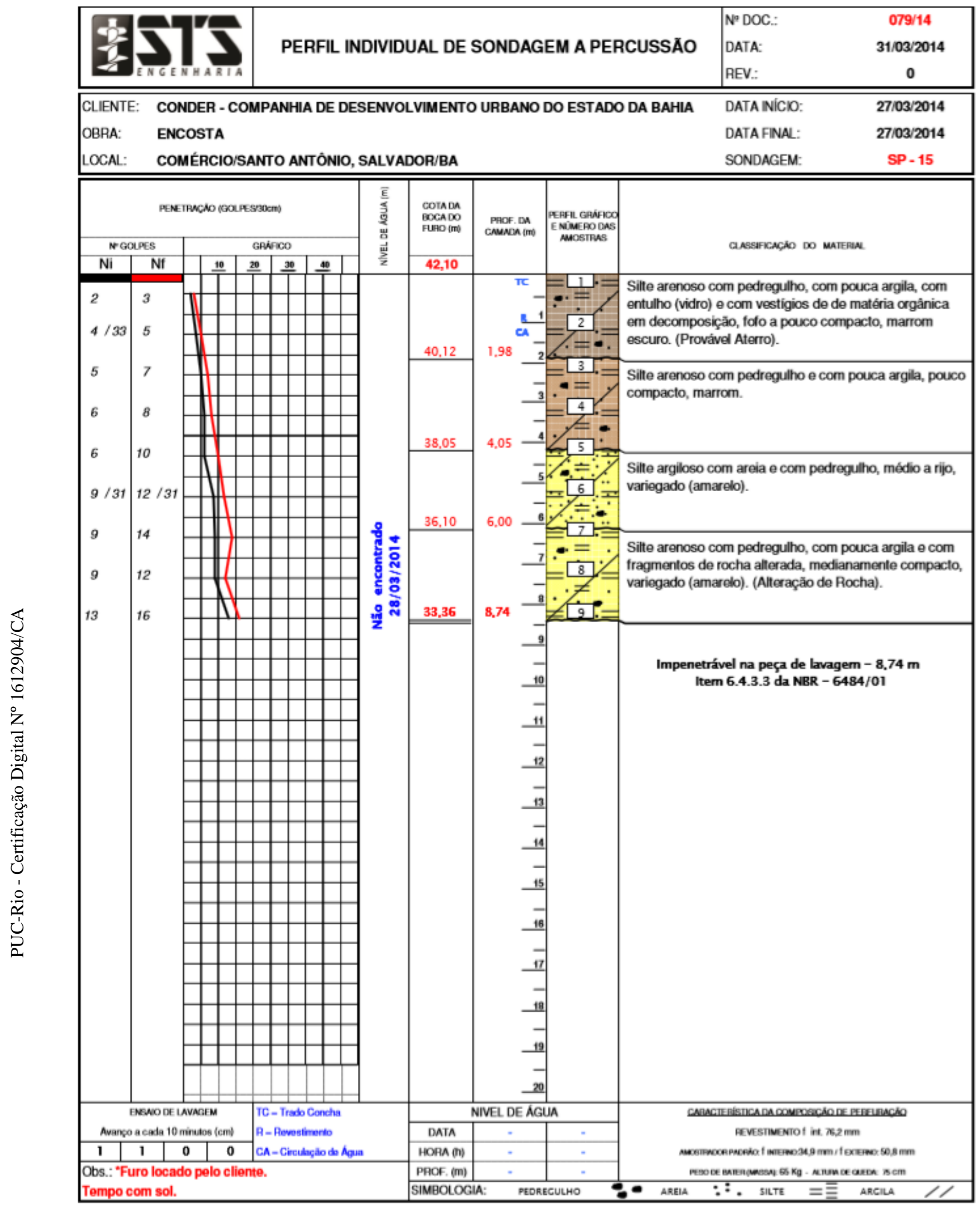




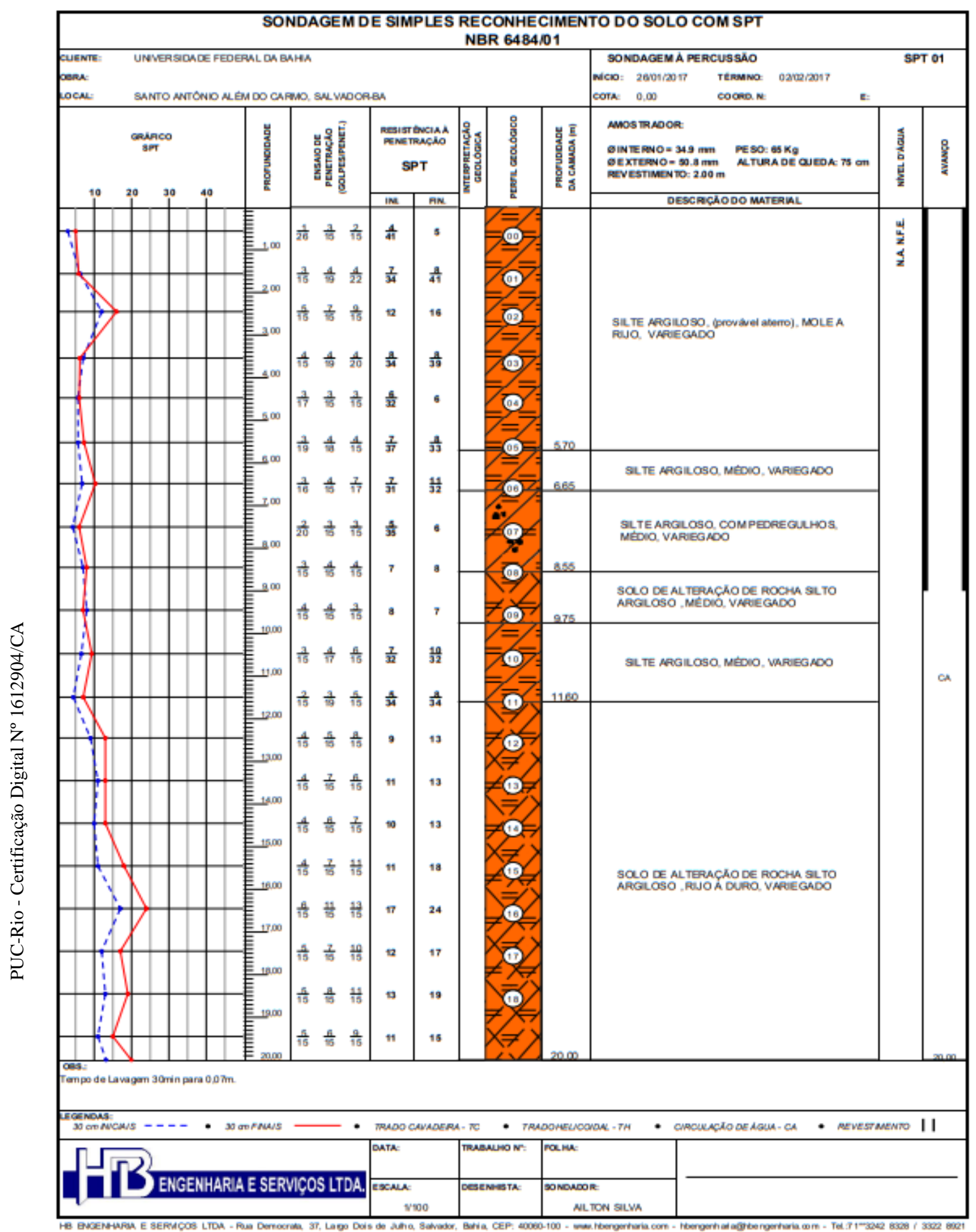




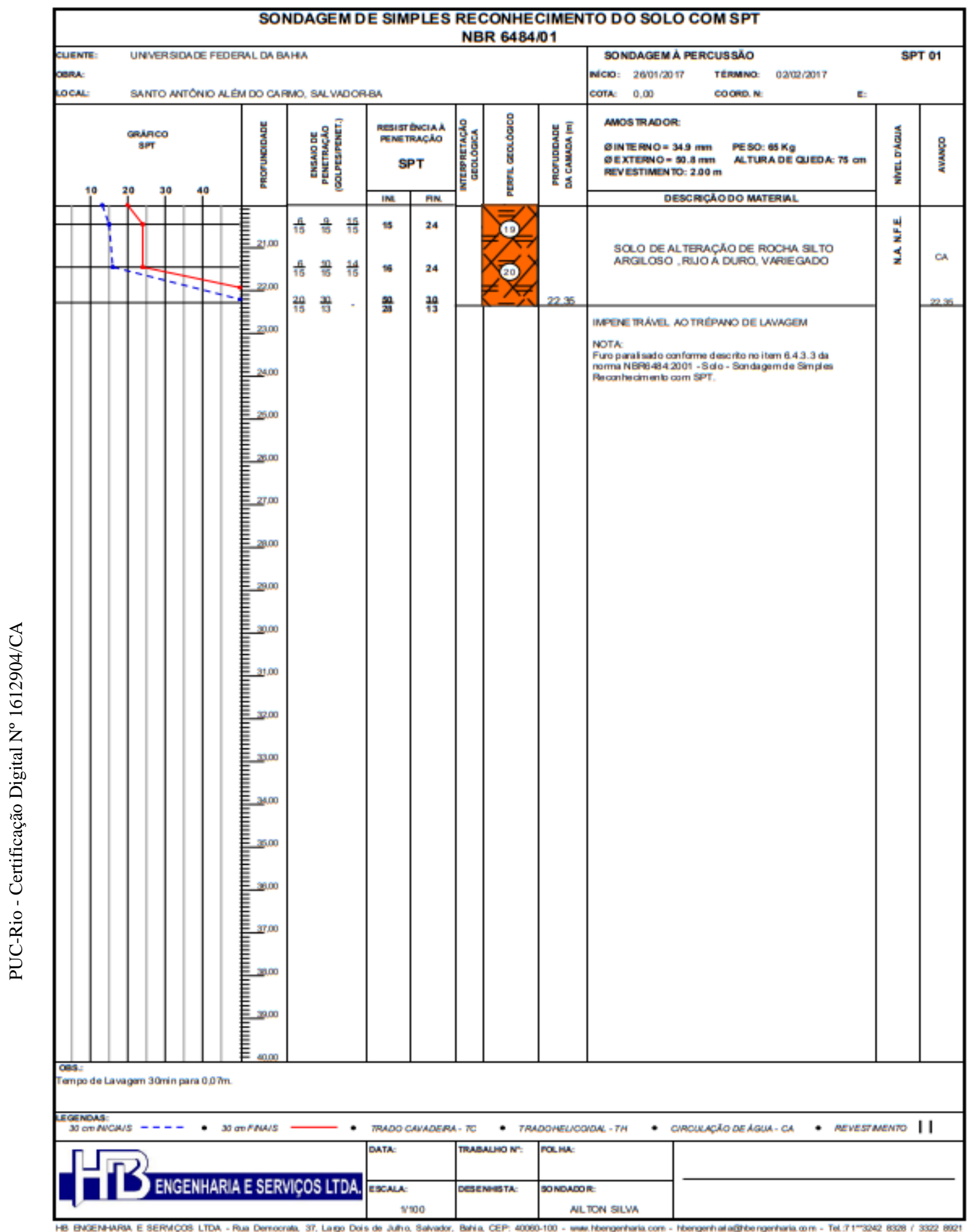




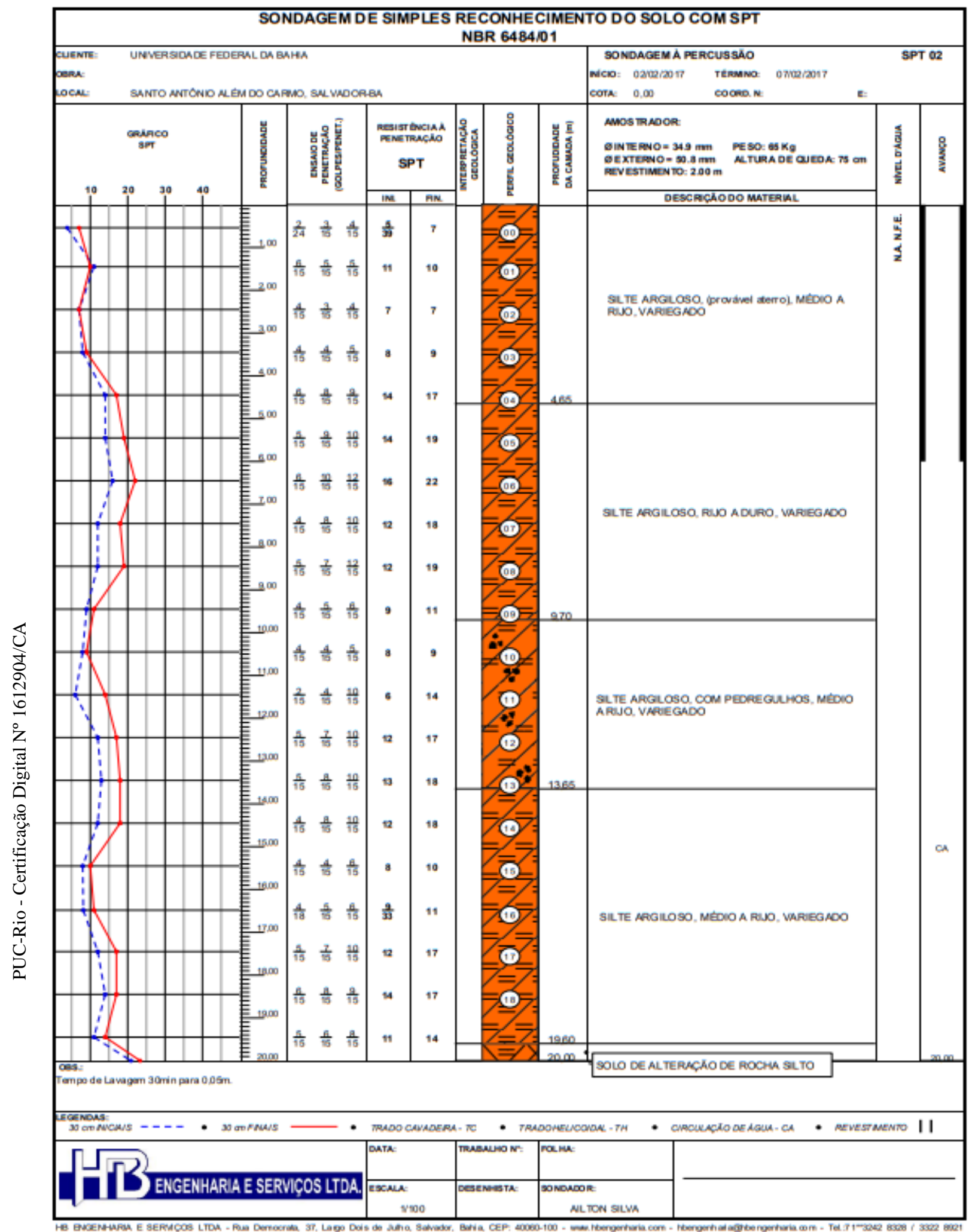




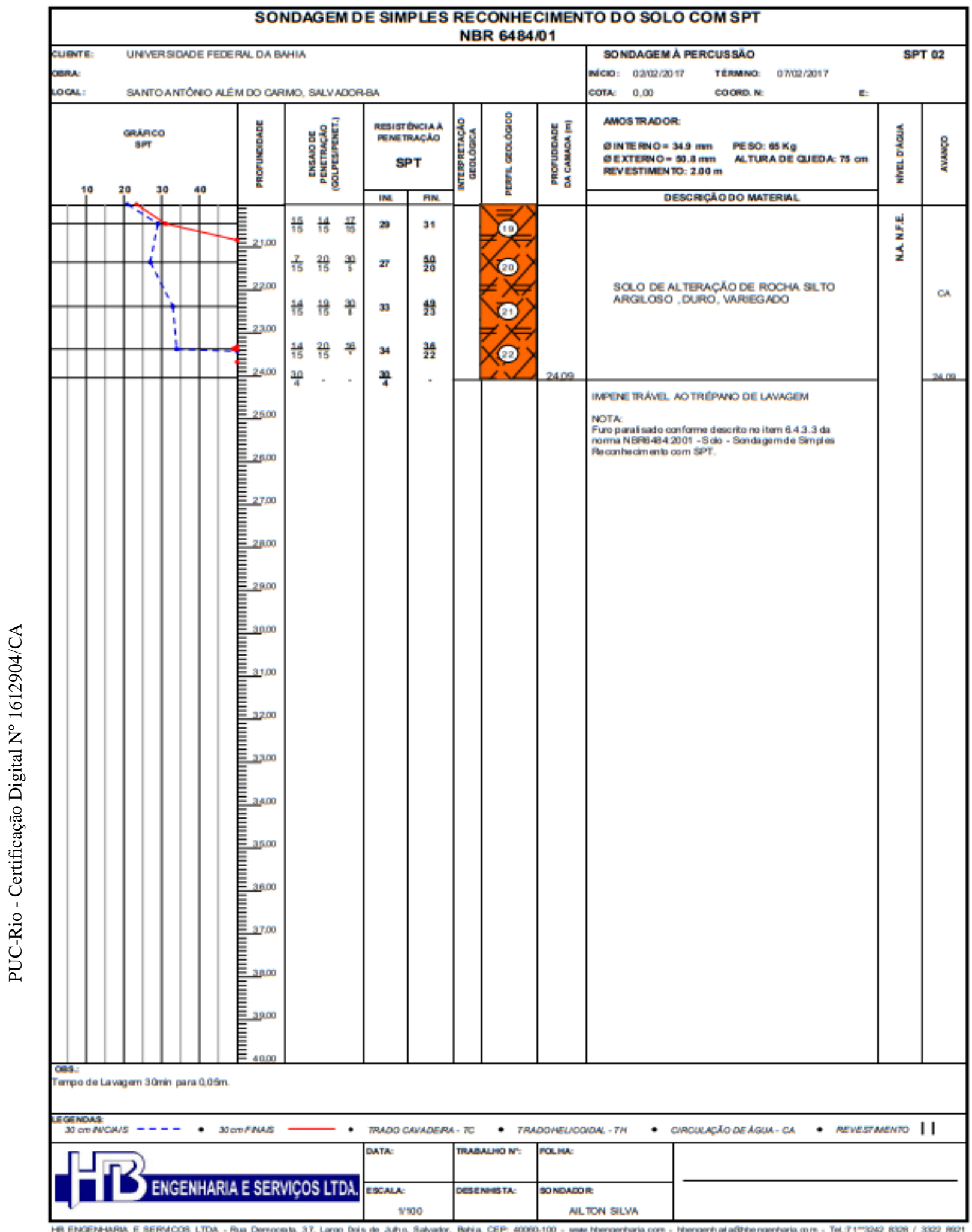




\section{Anexo II - Locação dos furos de sondagem}

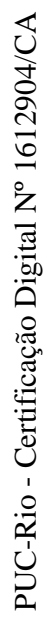

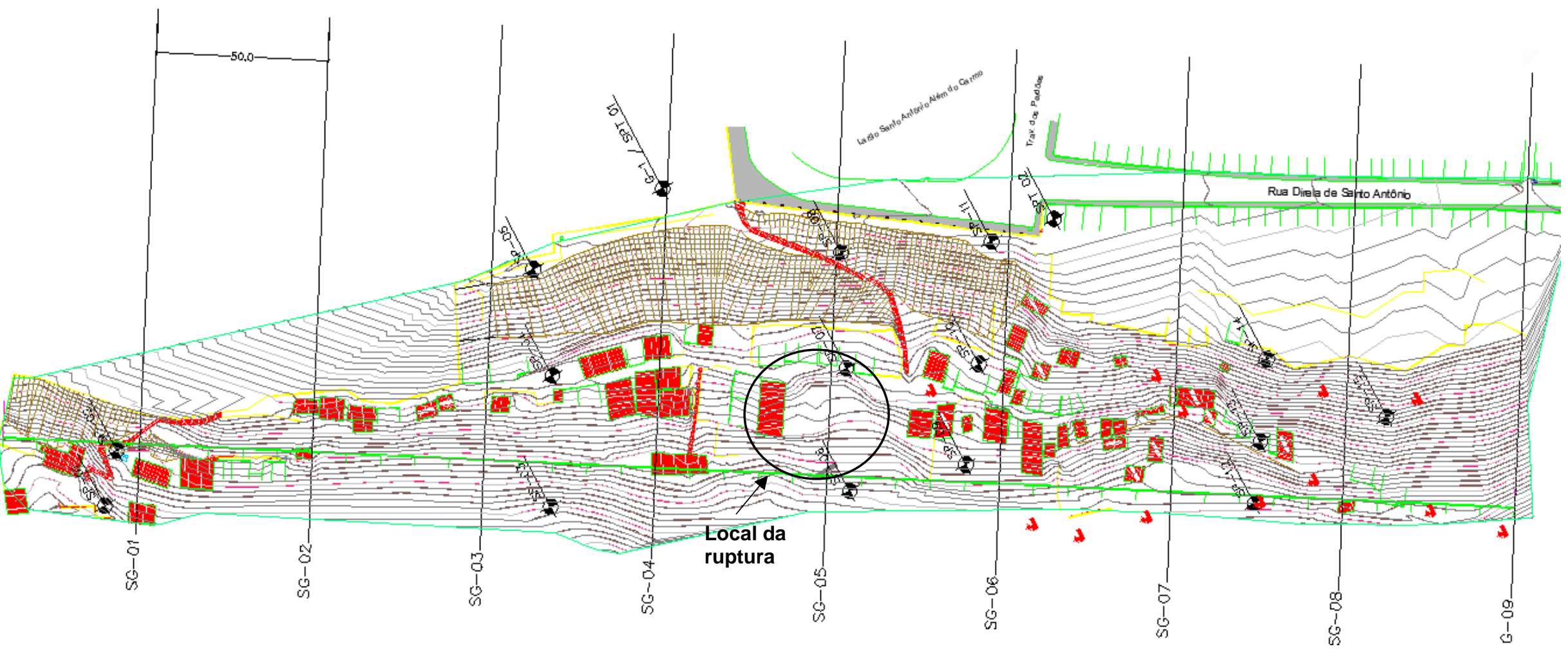

Figura A.1 - Locação dos furos de sondagem (Adaptado de Geoeng, 2014) 


\section{Anexo III - Perfis de SPT, umidade, e densidade real dos grãos}

- SPT 01

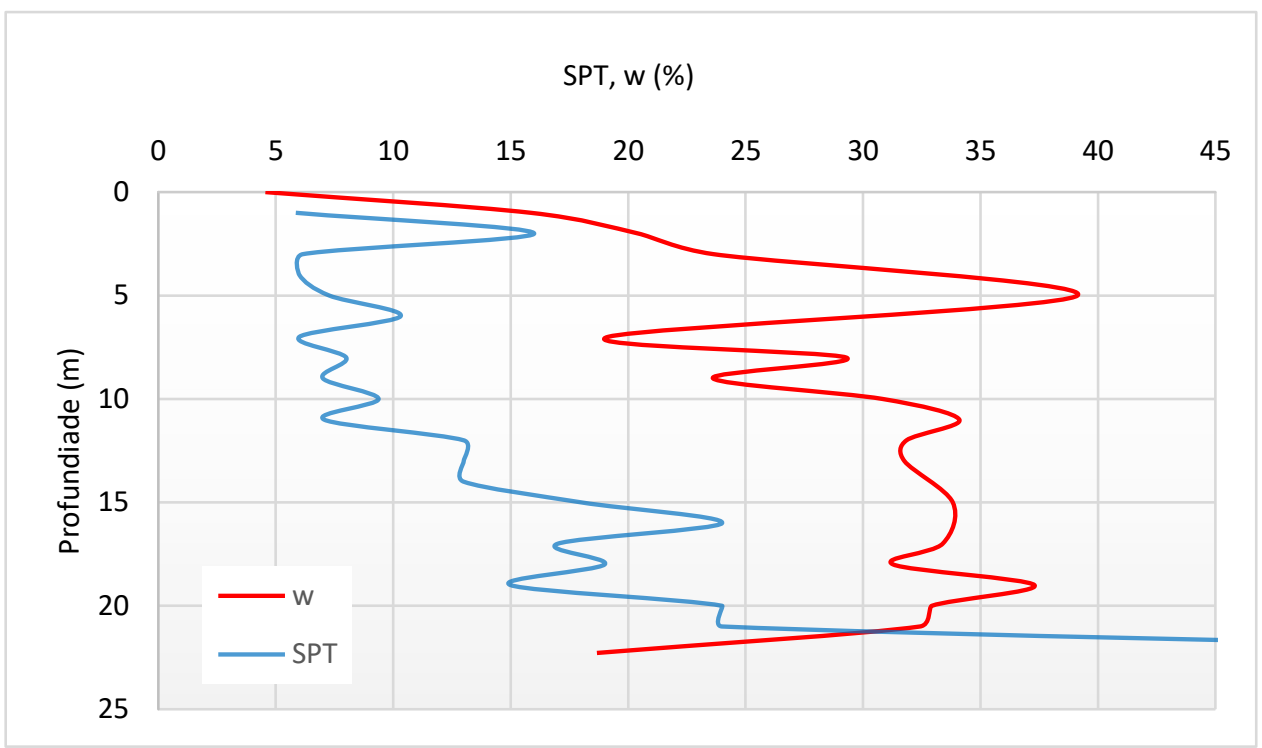

Figura A.2 - SPT e teor de umidade x profundidade para o SPT 01

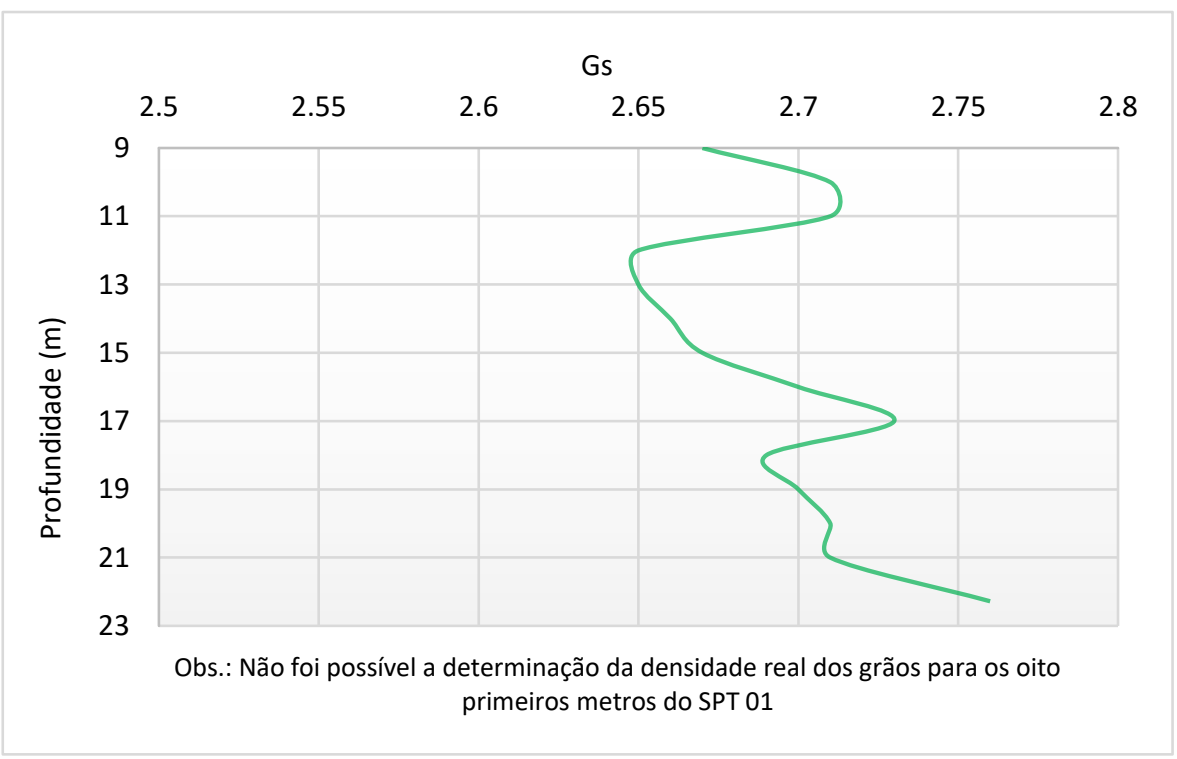

Figura A.3 - Densidade real dos grãos x profundidade para o SPT 01 
- SPT 02

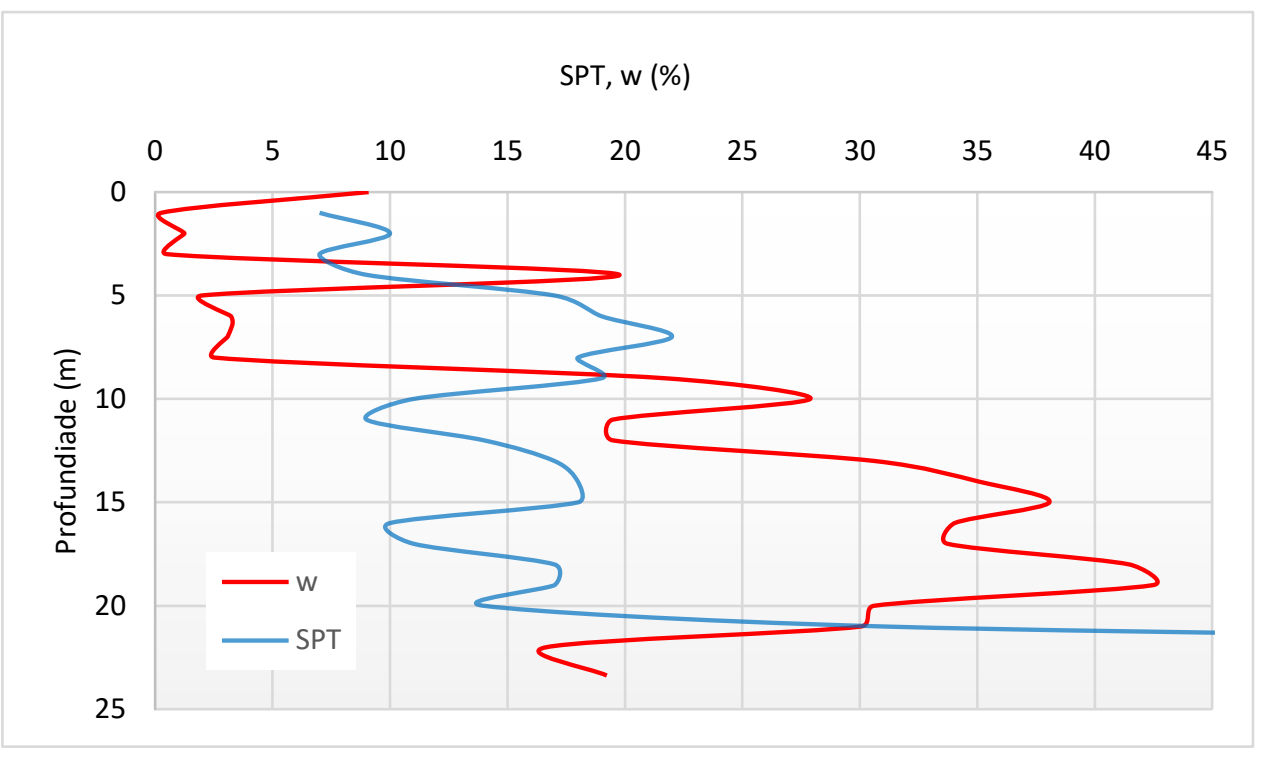

Figura A.4 - SPT e teor de umidade x profundidade para o SPT 02

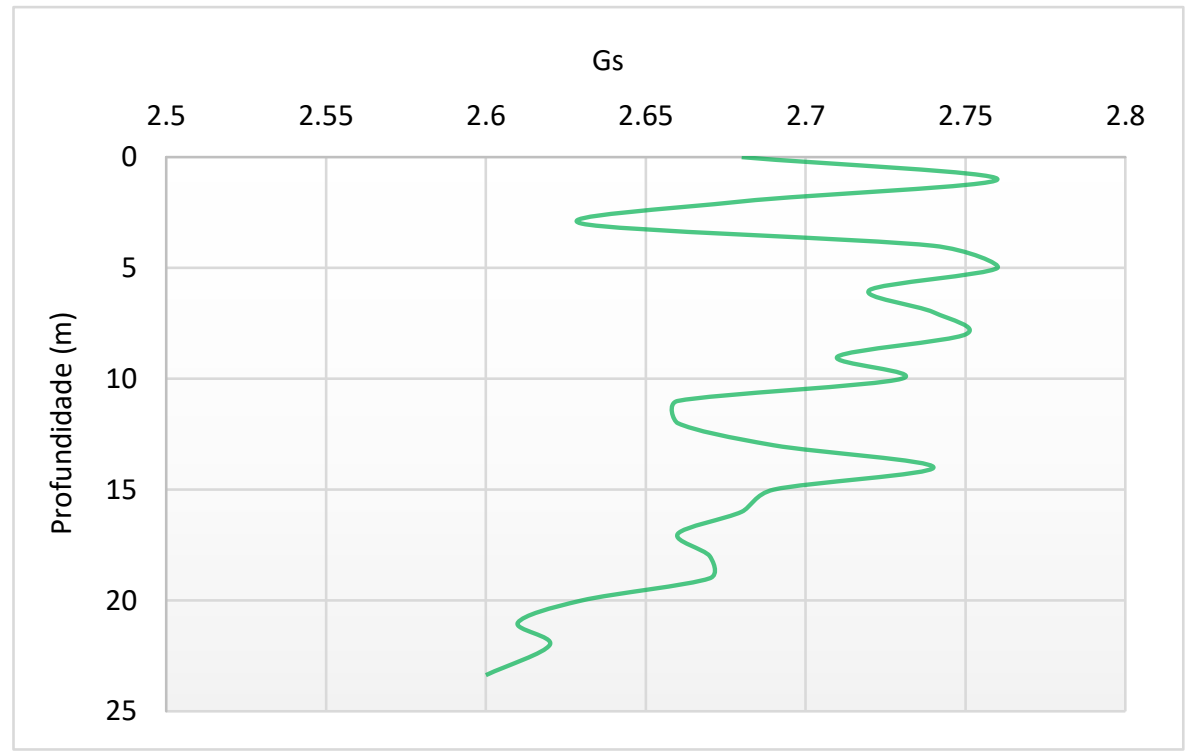

Figura A.5 - Densidade real dos grãos x profundidade para o SPT 02 